\title{
Verpleeghuisopname : een onderzoek naar factoren die van invloed zijn op verpleeghuisopname en het verloop daarvan
}

Citation for published version (APA):

te Wierik, M. J. M. (1991). Verpleeghuisopname : een onderzoek naar factoren die van invloed zijn op verpleeghuisopname en het verloop daarvan. [Doctoral Thesis, Maastricht University]. Rijksuniversiteit Limburg. https://doi.org/10.26481/dis.19911107mw

Document status and date:

Published: 01/01/1991

DOI:

10.26481/dis.19911107mw

Document Version:

Publisher's PDF, also known as Version of record

\section{Please check the document version of this publication:}

- A submitted manuscript is the version of the article upon submission and before peer-review. There can be important differences between the submitted version and the official published version of record.

People interested in the research are advised to contact the author for the final version of the publication, or visit the DOI to the publisher's website.

- The final author version and the galley proof are versions of the publication after peer review.

- The final published version features the final layout of the paper including the volume, issue and page numbers.

Link to publication

\footnotetext{
General rights rights.

- You may freely distribute the URL identifying the publication in the public portal. please follow below link for the End User Agreement:

www.umlib.nl/taverne-license

Take down policy

If you believe that this document breaches copyright please contact us at:

repository@maastrichtuniversity.nl

providing details and we will investigate your claim.
}

Copyright and moral rights for the publications made accessible in the public portal are retained by the authors and/or other copyright owners and it is a condition of accessing publications that users recognise and abide by the legal requirements associated with these

- Users may download and print one copy of any publication from the public portal for the purpose of private study or research.

- You may not further distribute the material or use it for any profit-making activity or commercial gain

If the publication is distributed under the terms of Article $25 \mathrm{fa}$ of the Dutch Copyright Act, indicated by the "Taverne" license above, 


\section{VERPLEEGHUISOPNAME}

Een onderzoek naar factoren die van Invloed zijn op verpleeghuisopname en het verloop daarvan 



\title{
VERPLEEGHUISOPNAME \\ Een onderzoek naar factoren die van invloed zijn \\ op verpleeghuisopname en het verloop daarvan
}

\section{PROEFSCHRIFT}

\author{
ter verkrijging van de graad van doctor \\ aan de Rijksuniversiteit Limburg te Maastricht, \\ op gezag van de Rector Magnificus, Prof. Mr. M.J. Cohen, \\ volgens het besluit van het College van Dekanen, \\ in het apenbaar te verdedigen \\ op donderdag 7 november 1991 om 14.00 uur
}

door

Margaretha Josephina Maria te Wierik

geboren te Raalte in 1962 
Promotor:

Co-promotores:

Beoordelingscommissie: Prof. dr. H. Philipsen, RL (voorzitter)

Prof. dr. H. Huijer Abu-Saad, RL

Prof. dr. J.A. Knottnerus, RL

Prof. drs. J.J.M. Michels, KUN

Prof. mr. F.C.B. van Wijmen, RL

CIP.GEGEVENS KONINKLIJKE BIBLIOTHEEK, DEN HAAG

Wierilk, Margaretha Josephina Maria te

Verpleeghuisopnarne : een onderzoek naar factoren die van inwloed zijn op verpleeghuisopname en het verloop daarvan

/ Margaretha Josephina Maria to Wierk. - Maastricht :

Datawyse. - III.

Met Englelse Nederlandse teksten. - Proetschrift

Maastricht. - Met lit. opg.

ISBN $90-5291-063-4$

NUGI 757

Trehw: verpleegtehuizen; sociaal-wetenschappelijk

onderzosk / verzorgingstehuizen ; sociaal-wetenschappelijk

onderzoek.

Produktie: Datawyse Maastricht

Lay-out: Thum Aarts Maastricht

Omslagontwerp: Mart van Golde Maastricht (e)

Druk: Krips Repro Meppel

In de drukkosten van het proefschrift werd bijgedragen door de Stichting Het Scholten-Cordes Fonds en het Fonds Doctor Catharine van Tussenbroek. 


\section{INHOUDSOPGAVE}

bylz.

Inleiding

II Het verpleeghuis

III Verpleeghuisopname; een onderzoek bij op te nemen ouderen

IV De hulpbehoefte en opnamewens van positief geilndiceerde ouderen voor het verzorgingshuis; een vergelijking met verzorgingshuisbewoners

$V$ Institutionalisering: een vergelijking van verpleeghuisaanvragers met verzorgingshuisaanvragers

(Institutionalization: a comparison of applicants to nursing homes and homes for the aged)

VI De ervaren belasting bij informele zorgverleners van verpleeg- en verzorgingshuisaanvragers

(Strain among informal caregivers of applicants to nursing homes and homes for the aged)

VII Het verloop van verpleeghuisopnamen

VIII Determinanten van de 'uitkomst' van verpleeghuisopnamen (Determinants of the outcome of nursing home stays)

IX Besluit

Summary

Samenvatting

Dankwoord

Curriculum Vitae 

HOOFDSTUK 1

INLEIDING 


\section{Inleiding}

In dit proefschrift staat het gebruik van het verpleeghuis door ouderen centraal. Het doel ervan is meer inzicht te geven in de redenen waarom ouderen in een verpleeghuis worden opgenomen en waarom sommige ouderen kort en anderen lang in een verpleeghuis verblijven. Dit proefschrift vormt het complement van het proefschrift van Frederiks (1990), dat eveneens het gebruik van zorg door ouderen als onderwerp heeft. In het gezamenlijke onderzoek komt zowel de intramurale als de extramurale zorg voor ouderen aan bod. Het gaat daarbil om de volgende zorgvoorzieningen:

- de professionele thuiszorg, i.c. de gezinszorg en wijkverpleging;

- het verzorgingshuis;

- het verpleeghuis.

In het proefschrift van Frederiks (1990) zijn gegevens van thuiswonende ouderen met en zonder professionele thuiszorg en van verzorgingshuisbewoners geanalyseerd, om factoren te vinden die het zorggebruik verklaren. In dit proefschrift worden, met hetzelfde doel, ouderen met een verpleeghuis-indicatie vergeleken met ouderen met een positieve indicatie voor het verzorgingshuis. Daarnaast worden longitudinale gegevens van ouderen die in een verpleeghuis werden opgenomen geanalyseerd, om factoren te identificeren die het verloop van de verpleeghuisopname beïnvloeden. Dit proefschrift bestaat voor het grootste deel uit (soms enigszins bewerkte) artikelen, waarin op verschillende aspecten van het onderzoek wordt ingegaan. Drie van deze artikelen/hoofdstukken hebben expliciet betrekking op de Nederlandse situatie en zijn daarom in het Nederlands geschreven; bij drie andere is Engels de voertaal. In elk van deze hoofdstukken worden de vraagstelling, de onderzoeksmethode, de analyse en de resultaten van het betreffende artikel weergegeven. Een gedeeltelijke overlap in de beschrijving van vraagstelling en methode is hierdoor onvermijdelijk. In deze inleiding wordt dan ook volstaan met een korte toelichting op de vraagstellingen, de uitwerking daarvan en de gevolgde onderzoeksmethoden.

\section{De vraagstellingen}

De huidige ouderenzorg staat onder druk. Een aantal belangrijke ontwikkelingen hebben hieraan bijgedragen.

Als eerste kan de demografische ontwikkeling in ons land genoemd worden: de 'ontgroening' en de 'dubbele vergrijzing'. Onder invloed van verbeterde leefomstandigheden (meer hygiëne, betere voeding en arbeidsomstandigheden) en medisch technologische ontwikkelingen is de levensverwachting enorm toegenomen. Momenteel is de levensverwachting bij geboorte voor mannen 73,7 jaar en voor vrouwen $80_{2} 2$ jaar (Ministerie van WVC 1990a). Voor wie eenmaal 65 jaar is geworden is dat respectievelijk 79 en 83,6 jaar (Ministerie van WVC 1990b). Doordat een aantal ziektes waaraan men vroeger overleed, nu te voorkómen of beter te behandelen is, krijgen andere - chronische - ziektes een kans om zich te ontwikkelen. Veelal brengen chronische ziektes hulpbehoevendheid met zich mee; voorbeelden hiervan zijn aandoeningen van het hart- en vaatstelsel en dementie. Met de toename in levensverwachting neemt dus ook het aantal hulpbehoevende ouderen toe.

De 'ontgroening' houdt in dat het aantal jongeren ( $0-19$ jaar) relatief afneemt, hetgeen vooral het gevolg is van een dalend aantal kinderen dat per vrouw geboren wordt. Vrouwen kregen in 1940 gemiddeld nog circa 3 kinderen; momenteel is dit minder dan 2 per vrouw (CBS 1989). Tezamen met andere maatschappelijke veranderingen, zoals een grotere mobiliteit, een toenemende arbeidsparticipatie van vrouwen en 
Kleinere huishoudens, betekent dit een drastische beperking van de mogelikheden van informele zorg voor ouderen door hun kinderen.

Tabel 1. Vergrijzing, ontgroening en de ontwikkeling in vier zorgvoorzileningen voor ouderen in de periode 1960-1990

\begin{tabular}{lrrrr} 
Voorzeningen & \multicolumn{1}{l}{1960} & \multicolumn{1}{c}{1970} & 1980 & \multicolumn{1}{c}{1990} \\
\hline Totale bevolking $(\times 1000)$ & $11.417,3$ & $12.957,6$ & $14,091,0$ & $14,892,6$ \\
Aandeel 0-19 jarigen $(\%)$ & 37,9 & 35,9 & 31,5 & 25,7 \\
Aandeel 65+-ers $(\%)$ & 8,9 & 10,1 & 11,5 & 12,8 \\
Aandeel 80+-ers van de 65+-ers $(\%)$ & 15,1 & 16,9 & 19,3 & 22,4
\end{tabular}

\section{Gezinszorg}

- uitvoerende krachten op full-time basis ${ }^{1}$

geen

- aantal oudere cliënten $(65 H)^{2}$

- aantal cliënten per 1000 ouderen

Wijkverpleging ${ }^{3}$

- bezette arbeiidsplaatsen

(1963)

3.373

Verzorgingshuizen

- aantal huizen

- aantal plaatsen ${ }^{4}$

Verpleeghuizen

- aantal huizen

- aantal bedden
(1965)

1.724

78.188

(1963)

106

8.204
1.880

117.901

1.547

144.798
(1989)

40.302

149.300

79
126.612

78

11.854

143.900

1 Het ciffer bij 1990 betreft het aantal arbeidsjaren in 1989 .

2 Het cijfer in 1980 is exclusief alpha-hulpwerlening; het cifer bij 1990 is het aantal oudere clienten in de laatste vier weken in 1989.

3 Gegevens over het leeftijdsspecifiek gebruik zijn pas wanaf 1985 beschikbaar.

4 Inclusief bedden op verpleegaldelingen, ziekenkamers en 1 oktoberbedden; in 1965 waren van 196 huizen geen gegevens beschikbaar over het aantal plaatsen.

Bronnen: Ministerie van WVC 1990a, CBS verschillende jaren, Brouwer et al. 1986

Tegelijkertijd deed zich echter een belangrijke ontwikkeling voor, waardoor voor hulpbehoevende ouderen informele zorg niet meer de enige bron van hulp was. Met de ontwikkeling van het sociale verzekeringsstelsel werden allerlei zorgvoorzieningen voor iedereen toegankelijk. Door de economische groei in de periode na de Tweede Wereldoorlog konden verschillende volksverzekeringen, zoals de Algemene BijstandsWet en de Algemene Wet Bijzondere Ziektekosten, maar ook subsidieregelingen voor bijvoorbeeld kruisverenigingen en gezinszorg tot stand worden gebracht. Doordat de financiering van de zorg hierdoor gewaarborgd was, konden allerlei voorzieningen zich uitbreiden. In tabel 1 is deze ontwikkeling voor de belangrijkste voorzieningen voor ouderen weergegeven. Ter vergelijking zijn in de tabel tevens een aantal gegevens over de 'vergrijzing' en 'ontgroening' opgenomen.

Halverwege de jaren zeventig ontstond de behoefte het beleid te wijzigen omdat met het toenemend aantal ouderen en de stagnatie in de economische ontwikkeling de 
zorg woor ouderen bij ongewizzigd beleid onbetaalbaar zou worden (Tweede Kamer 1975). Vanaf het begin van de jaren 80 volgden de overheidsnota's aangaande de zorg voor ouderen elkaar in snel tempo op. Ter illustratie: in 1982 verscheen de nota Bouwstenen woor een ouderenbeleid; in 1983 de Beleidsbrief Ouderenbeleid en de nota Flankerend Bejaardenbeleid; in 1986 Zorg voor Ouderen en Kosten van Vergrijzing voor WV en in 1988 de nota Ouderenbeleid, voortgangsrapportage 1982 1988 (zie voor een uitgebreid overzicht Huijsman 1990). Het streven ouderen zo lang mogelik in de thuissituatie te laten functioneren, wordt in deze nota's centraal gesteld. De omstandigheden, die zelfstandig wonen mogelijk maken, dienen daartoe bevorderd te worden en het gebruik van intramurale zorg teruggedrongen. Getracht wordt verschuivingen in het zorggebruik te bewerkstelligen van professionele zorg naar informele zorg en zelfzorg, van (dure) intramurale zorg naar (goedkopere) semi- en extramurale zorg en van curatieve naar preventieve zorg.

In dit kader is een onderzoek naar de omstandigheden die "naast de mate van invaliditeit, leiden tot het gebruik van professionele zorg beleidsrelevant. De eerste wraagstelling van dit onderzoek luidt dan ook: wellke factoren leiden bil ouderen, naast de mate van invaliditeil, tot opname in een verpleeghuis?

Omdat het verpleeghuis verschillende functies vervult - reactivering, chronische zorg en terminale zorg - is het eveneens van belang om te onderzoeken welke ouderen na reactivering met een verbeterd functioneren naar huis of naar een verzorgingshuis ontslagen kunnen worden "en welke ouderen na een kort of langer durend verbliff in het verpleeghuis overlijden. De tweede vraagstelling is dan ook: welke factoren bepalen het verloop van de verpleeghuisopname?

Inzicht in factoren die van invloed zijn op verpleeghuisopname en het verloop daarvan kan gebruikt worden bij:

1 de preventie: indien bepaalde factoren manipuleerbaar zijn, kan door gerichte interventies de vraag naar opname mogelijk voorkomen dan well uitgesteld worden;

2 de planning: door meeweging van andere factoren dan de mate van invaliditeit c.q. van factoren die het verloop bepalen, kan een betere prognose van de toekomstige behoefte aan verpleeghuizen gemaakt worden;

3 het formuleren van een indicatie- en opnamebeleid: wanneer er overeenstemming bestaat over de doelgroep van verpleeghuizen kunnen op basis van deze factoren de criteria voor opname en (voortgezet) verbliff specifieker omschreven worden;

$4 \mathrm{de}$ invulling van de zorg: informatie over deze factoren geeft aan hoe de zorg inhoudelijk beter afgestemd kan worden op de werkelijke behoefte.

\section{Toelichting op de vraagstellingen}

Wit een aantal studies komt naar voren dat de gezondheidstoestand en/of de functionele beperkingen alléén de vraag naar professionele zorg niet kunnen verklaren. In deze studies werd de hulpbehoefte van ouderen bepalald, veellal in termen van functionele beperkingen, en vervolgens in verband gebracht met hun (vraag naar) zorggebruik. Er bleken niet alleen ouderen te zijn met een grote hulpbehoefte die geen gebruik maakten van professionele zorg, maar ook ouderen met weinig beperkingen die wel professionele zorg zouden willen gebruiken (Fennis 1973, De Amsterdamse bejaarden 1977. George en Maddox 1989). Deze discrepantie tussen hulpbehoefte en (vraag naar) zorggebruik geeft aan dat naast de hulpbehoefte andere factoren een rol spelen. In een groot aantal andere studies is expliciet een scala van factoren onderzocht op hun invloed op het gebruik van (gezondheids) zorgvoorzieningen. Om deze factoren op een inzichtelijke manier te ordenen is het model van Andersen (1975) bruikbaar. Volgens dit model is het gebruik van voorzieningen 
afhankelijk van de predispositie om gebruik te maken van voorzieningen (predisponerende factoren), de mogelijkheden om zorg te gebruiken (faciliterende factoren) en de behoefte aan zorg (behoeftefactoren).

Tot de predisponerende component behoren die factoren, die al aanwezig zijn voor het ontstaan van het gezondheidsprobleem c.q. de hulpbehoefte. Er wordt hierbij een onderscheid gemaakt in demografische en sociaal-structurele variabelen en in variabelen die de houding ten aanzien van gezondheidszorg en de baten die men ervan verwacht weergeven (belief variables).

Faciliterende factoren zijn die factoren die iemand in staat stellen om de gewenste zorg te kunnen gebruiken; zij hebben dus met de toegankelijkheid van voorzieningen in ruime zin te maken. Tot deze factoren behoren niet alleen de financiële mogelijkheden van de ouderen en de bereikbaarheid van voorzjeningen door de oudere, maar ook het bestaande aanbod van voorzieningen.

De behoeftecomponent wordt gevormd door de directe aanleiding voor de vraag naar zorg en betreft dus de gezondheidstoestand en/of de hulpbehoefte. Er wordt daarbij onderscheid gemaakt tussen de objectieve en subjectieve behoefte.

In figuur 1 is het model van Andersen schematisch weergegeven. Het model impliceert dat de geneigdheid tot zorggebruik (predisposing factors) wordt omgezet in daadwerkelijk gebruik wanneer de mogelijkheden daartoe (enabling factors) aanwezig zijn. Beide groepen factoren zijn echter niet genoeg: een (subjectieve) noodzaak tot zorggebruik (need factors) dient eveneens aanwezig te zijn. De groepen factoren die bijdragen aan het gebruik van zorg zijn hiermee duidelijk geordend. Een indeling van specifieke factoren naar hoofdcomponent is echter minder eenduidig. Zo kan bijvoorbeeld de mobiliteit zowel tot de faciliterende als tot de behoeftefactoren gerekend worden, afhankelijk van de voorziening waarin men geïnteresseerd is. Op analoge wijze kan de geestelijke toestand als een behoeftefactor of als een predisponerende factor beschouwd worden. Bij gebruik van het Riagg behoort de mobiliteit tot de faciliterende en de geestelijke toestand tot de behoeftecomponent; bij een aanvraag voor een plaats in een verzorgingshuis maakt de mobiliteit deel uit van de behoeftefactoren en kan de geestelijke toestand gezien worden als predisponerende factor die mede van invloed is op de aanvraag.

In een groot aantal studies is de invloed van een diversiteit aan factoren onderzocht voor allerlei (gezondheids)zorgvoorzieningen. In hoofdstuk 5 wordt, gerangschikt naar het model van Andersen, een overzicht gegeven van de factoren die in eerder onderzoek van invloed zijn gebleken op het gebruik van verpleeghuizen of van institutionele zorg.

Ook het verloop van verpleeghuisopnamen en de factoren die daarop van invloed zijn, de tweede vraagstelling, zijn eerder onderwerp van studie geweest. De patiëntenpopulatie van verpleeghuizen is heterogeen. De ouderen worden met zeer verschillende aandoeningen vanuit de thuissituatie, het ziekenhuis of het verzorgingshuis opgenomen voor reactivering, chronische of terminale zorg. Bij een deel van de reactiveringspatiënten heeft de opname niet het gewenste resultaat en verblijven zij tot aan hun dood in het verpleeghuis; een deel van de chronische patiënten gaat toch nog naar huis of naar een verzorgingshuis. De verblijfsduur laat een grote spreiding zien.

De studies naar het verloop van de verpleeghuisopnamen gingen veelal uit van de ontslagstatus: overlijden of ontslag naar huis, verzorgingshuis of ziekenhuis. Een klein aantal studies richtte zich op de verblijfsduur, en vergeleek kort verblijf (korter dan 6 of 3 maanden) met langer verblijf, zonder onderscheid te maken in ontslag of overlijden. In dit onderzoek zịn de patiënten maximaal 1 jaar gevolgd; de situatie na 1 jaar bestaat dan uit ontslagen, overleden of nog opgenomen zijn. De gezondheidstoe- 
stand heeft in de eerdere studies naar het verloop van de verpleeghuisopnamen veel nadruk gekregen. De gezondheidstoestand werd daarbij weergeven door de hoofddiagnose en/of door verschillende aspecten van de functionele status. Afgezien van demografische variabelen zijn andere factoren, die bij de verklaring van de vraag naar zorgvoorzieningen gerangschikt kunnen worden onder de predisponerende en faciliterende factoren, in mindere mate onderzocht op hun invloed op het verloop van de opname. In hoofdstuk 8 worden, gerangschilkt naar factor, de resultaten van deze studies weergegeven.

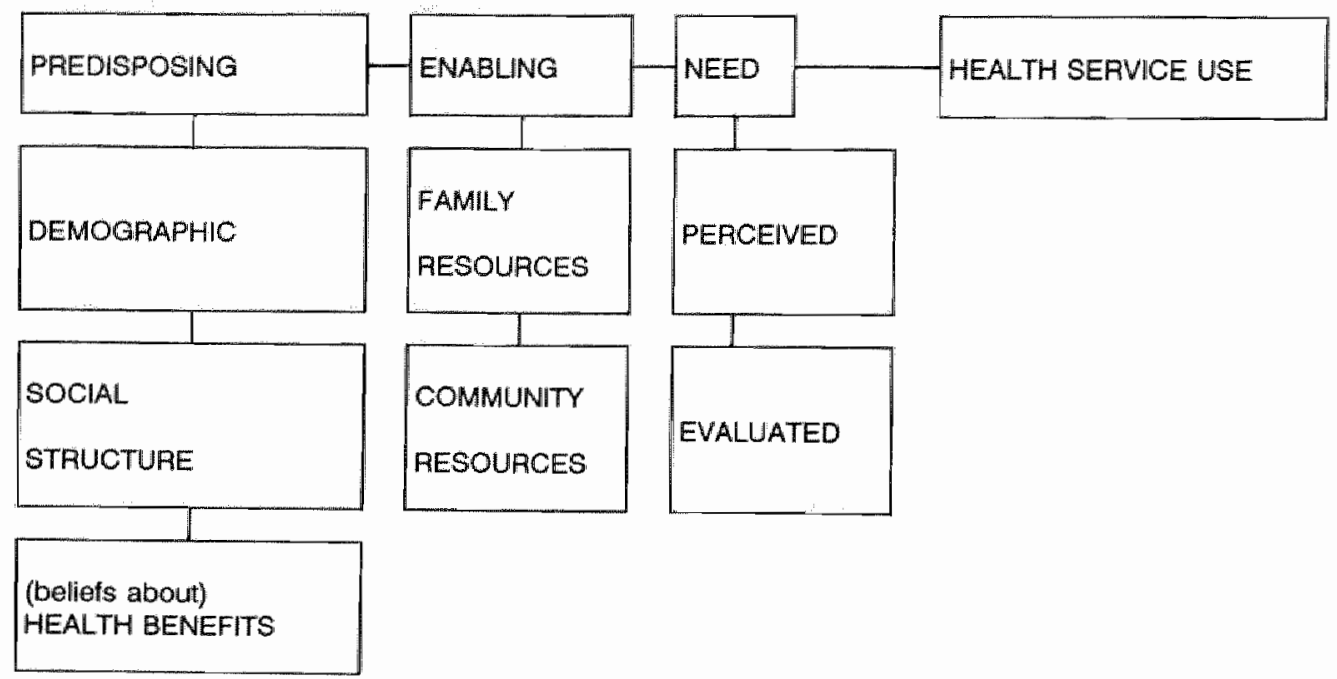

Figuur 1. Andersens modell ter verklaring van het gebruik van woorzieningen

\section{Onderzoeksopzet}

De twee vraagstellingen zijn leder in een eigen onderzoeksopzet beschreven. Om na te gaan of predisponerende en faciliterende factoren, naast de behoeftefactoren, een onafhankelijke bijdrage leveren aan opname in een verpleeghuis, is een longitudinale opzet het meest ideaal. In zo'n opzet worden ouderen, die (nog) niet zijn opgenomen in een verpleeghuis, in de tijd gevolgd waardoor nagegaan kan worden onder welke omstandigheden men overgaat tot opname. Een praktisch nadeel van zo'n opzet is dat een zeer grote groep ouderen over een lange tijd gevolgd moet worden om voldoende ouderen te vinden die worden opgenomen in een verpleeghuis. Een efficiëntere methode is om een aantal ouderen die zijn opgenomen in een verpleeghuis te vergelijken met een aantal ouderen die niet zijn opgenomen maar die een min of meer overeenkomstige mate van invaliditeit hebben. Deze methode kent evenwel ook beperkingen. Een eerste is dat, naarmate men langer is opgenomen, de kans groter wordt dat de huidige omstandigheden verschillen van de omstandigheden waaronder men werd opgenomen. Bovendien hebben ouderen die opgenomen zijn in een verpleeghuis in het algemeen meer functionele beperkingen dan ouderen die elders (thuis of in een verzorgingshuis) verblijven. De bedoeling is immers om de invloed van factoren, anders dan de mate van invaliditeit, te onderzoeken. De eerste beperking wordt opgeheven door in plaats van reeds apgenomen ouderen, aanvragers van verpleeghuiszorg, dus ouderen met een 
verplleeghuisindicatie, in het onderzoek op te nemen. Het tweede probleem is moeilijker op te lossen. Voor de vraagstelling is het nodig een vergelijkingsgroep te vinden van ouderen zonder een aanvraag voor opname in een verpleeghuis maar met een zelfde mate van invaliditeit. In alle denkbare categorieën ouderen met een bepaald zorggebruik (inclusief geen gebruik) zijn well ouderen te vinden met evenveel beperkingen als verpleeghuisaanvragers; hun aantal varieert echter. De vergelijkingsgroep kan nu op twee manieren samengesteld worden. Enerzijds door die ouderen te nemen die, ongeacht hun zorggebruik, een zelfde mate van invaliditeit hebben, anderzijds door die groep ouderen te nemen met een bepaald zorggebruik, die qua invaliditeit het meest lijkt op verpleeghuisaanvragers. De eerste manier heeft zowel praktische als theoretische bezwaren. Om ouderen in alle categorieën zorggebruik met een zelfde mate van invaliditeit als verpleeghuisaanwragers te vinden is niet alleen de medewerking van alle zorgverlenende instanties nodig. Ook moeten van alle gebruikers gegevens over de mate van invaliditeit bekend zijn, op basis waarvan de selectie voor de vergelijkingsgroep kan plaatswinden. Nog afgezien van de inspanningen die nodig zijn om thuiswonende ouderen zonder zorggebruik maar met een zelfde mate van invaliditeit te vinden, is dit een arbeidsintensieve methode. Om een voldoende grote vergelijkingsgroep samen te stellen moeten gegevens - zo die al beschikbaar zijn - van veel gebruikers gescreend worden. Daarnaast ontstaat dan het theoretische probleem dat bepaalde kenmerken, die we willen onderzoeken op hun invloed op het zorggebruik "deels bepaald worden door dat zorggebruik; bij bijvoorbeeld verzorgingshuisbewoners is de woning altijd aangepast en is informele zorg niet (meer) nodig omdat de zorg vanuit de instelling geboden wordt. Deze problemen doen zich niet voor bij de tweede manier om de vergelijkingsgroep samen te stellen. Op basis van het onderzoek van Remmen (1985) is dan ook besloten om aanvragers van verzorgingshuizen, dus ouderen met een positieve indicatie voor het verzorgingshuis, als vergelijkingsgroep te nemen. Remmen onderzocht de gezondheidstoestand van ouderen die langer dan 1 jaar waren opgenomen in een somatisch verpleeghuis en in een verzorgingshuis en concludeerde dat de aard van de invaliditeit van verpleeg- en verzorgingshuisbewoners vergelijkbaar is. Wel bleken de verpleeghuisbewoners er ernstiger aan toe te zijn, in die zin dat er bij hen meer diagnosen en klachten aangegeven werden en dat zij meer ADL-beperkingen hadden. Hoewel het laatste suggereert dat verzorgingshuisaanvragers qua hulpbehoefte niet geheel vergelijkbaar zullen zijn met verpleeghuisaanvragers, leek deze groep toch de beste benadering te zijn.

Het onderzoek vond plaats in Maastricht. Ouderen vanaf 55 jaar werden in het onderzoek betrokken. Hoewel een leeftijdsgrens van 65 jaar meer voor de hand ligt, ook al omdat ouderen pas vanaf 65 jaar gebruik kunnen maken van een verzorgingshuis, werd hiervoor gekozen omdat de verzamelde gegevens dan eveneens gebruikt konden worden woor het project 'Een model van voorzieningen voor ouderen' dat eveneens aan de Rijksuniversiteit Lilmburg uitgevoerd is (Huijsman 1990). Een overzicht van de studiepopulatie wordt gepresenteerd in figuur 2, waarin ook het parallelonderzoek van Frederiks (1990) verwerkt is.

Als methode van gegevensverzameling is gekozen voor mondelinge interviews met de oudere zelf en/of een informele zorgverlener (indien aanwezig). Met behulp van gestructureerde vragenlijsten werd informatie verzameld over demografische kenmerken, het sociale netwerk inclusief de belasting van de informele zorgverleners, de geestelijke toestand, de woonsituatie (als predisponerende factoren), de sociaaleconomische status, het gebruik van professionele thuiszorg (als faciliterende factoren) en het aantal lichamelijke beperkingen (als behoeftefactor). Voor de operationalisatie van deze variabelen wordt verwezen naar de hoofdstukken $3 \mathrm{t} / \mathrm{m} 6$ en 8 . 
Mismormigt

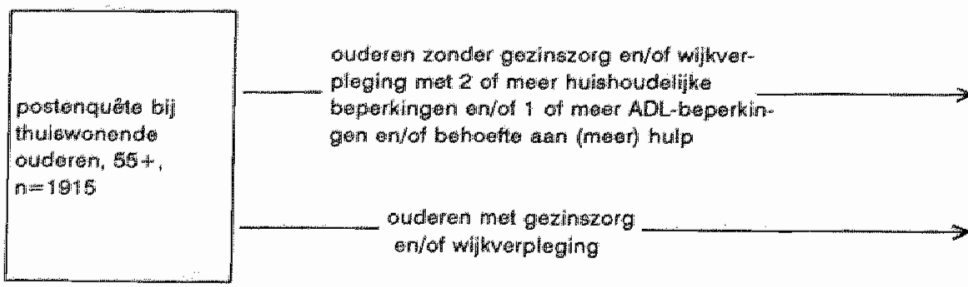

Wia do shichting gezimszor an de regionale krulswereming

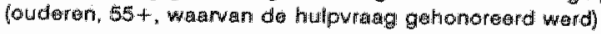

mondelinge interwisws mot:

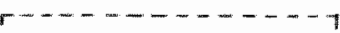

1. thustiswonde oucleren zonder professionele zorg: $n=327$

2. thithiswonende ouderen met profossionele zong $n=123$

aanwragers van protessionele thuiszong. (Deze categlarie cuderen is door de vijuwel algehele nionrespons niet bil de analy'ses betrokken

4. verzergingsthuisbewoners $n=207$

via de werzorgingshuizen (asclecte steekproaf uit de bowonera)

5. aanvragers wan verzorgingshutizen $n=1.35$

a de gemeantelijke indicatiecommissie (alle ouderen met een positieve indicatic) (atle ouderen $55+$, mot een gehonoroerde sanwraag, uitgezonclerd terminale patiênten!
6. aanwragars wan varpleaghuizen $n=157$

II het proefschrift wan Frederilks (1990) zijn thenmerken van deze categorieün oudaran geanalyseerd.

If In dit proefschrift wonden kenmerken van dezo categorieên ouderen geanalyseerd.

Figutur 2. De studiepopulatio van het gohele anderzook in Mastricht

Voor de tweede vraagstelling, waarin het verloop van de verpleeghuisopnamen centraal staat, is een longitudinale opzet gehanteerd. De ouderen die werden opgenomen in één van de twee verpleeghuizen in Maastricht zijn na opname maximaal 1 jaar gevolgd. De veronderstelling daarbij was dat binnen 1 jaar de reactiveerbare patiënten uit het verpleeghuis zouden zijn ontslagen en dat zij die na 1 jaar nog opgenomen waren 'long-stay' patiënten zouden worden. Op twee manieren werd aanvullende informatie verzameld. De behandelend verpleeghuisarts vulde kort na opname en bij ontslag of overlijden c.q. na 1 jaar opname een schriftelijke vragenlijst in. De vragen hadden betrekking op de diagnosen, de functionele status, (het bereiken van) de behandeldoelen en de prognose. Daarnaast werd 2 weken na opname, en vervolgens verbleef een 3 manden, door het verplegend personeel van de afdeling waar de patient Kam et al. 1971) Veordelingsschaal voor Oudere Patiënten (BOP) gescoord (Van der andere variat ). Voor een toelichting op de BOP en de operationalisatie van de

\section{Opbouw}

Het proefschrift is als volgt opgebouwd. Het tweede hoofdstuk is een algemene inleiding over verpleeghuizen in Nederland. Na een korte schets van de ontstaans- 
geschiedenis wordt het functioneren ervan en het huidige beleid rond verpleeghuizen uiteengezet. De groep verpleeghuisaanvragers vormen het ondenwerp van het derde hoofdstuk. Nagegaan wordt of er verschillen zijn naar aard van verblijf vóór ophame en doel van de opname en in hoeverre bij deze ouderen substitutie van zorg mogelijk is. De groep verzorgingshuisaanvragers komt in het vierde hooldstuk aan de orde. Naast een vergelijking met verzorgingshuisbewoners wordt ook in dit hoofdstuk gekeken naar de mogelijkheden van substitutie van zorg. In het volgende hoofdstuk worden beide groepen aanvragers vergeleken. Hoofdstuk 6 glaat in op de belasting die de informele zorgverleners van deze ouderen ervaren. De hoofdstukken 7 en 8 hebben betrekking op de tweede vraagstelling van het onderzoek. In hoofdstuk 7 wordt met behulp van de Beoordelingsschaal voor Oudere Patienten het verloop van de verpleeghuisopnamen weergegeven; voor de reactiveringspatiënten wordt nagegaan welke factoren ontslag uit het verpleeghuis bevorderen dan wel belemmeren. In hoofdstuk 8 worden opmame-kenmerken van de opgenomen verpleeghuispatiënten gerelateerd aan de 'uitkomst" van de opname na 1 jaar (ontslag, overlijden of nog opgenomen). In het laatste hoofdstuk worden de resultaten van het onderzoek in thun geheel nog eens belicht en met elkaar in verband gebracht. Ook worden daarin een aantal beleidsimplicaties besproken en aanbevelingen gedaan voor verder onderzoek en voor de zorgverlening aan ouderen. 


\section{Literafuur}

De Amsterdamse bejaarden in 1976. Amsterdam, Veldkamp Markt-onderzoek BV 1977.

Andersen $R_{x}$ Kravits J, Anderson OW (eds). Equity in health services: empirical analysis in social policy. Cambridge, Mass., Ballinger Publishing Company 1975.

Brouwer JK, Imamdi MK, Spaan JM. Het verpleeghuis in cijfers. Utrecht, NZI 1986.

CBS:

- Maandstatistiek bevolking. 1989; aktober: 14-15.

- Statistisch Zakboek '68/72/1981/1982. Den Haag, Staatsuitgeverij 1968/1972/1981/ 1982.

- Statistisch Jaarboek 1991. Den Haag, SDU uitgeverij 1991.

- 1899-1989. Negentig jaren statistiek in tijdsreeksen. Den Haag, SDU uitgeverij 1989.

- Statistiek van de gezinsverzorging en gezinshulp 1970/1979 en 1980. Den Haag, Staatsuitgeverij 1973/1983.

- Statistiek van de bejaardenoorden 1970/1979 en 1980. Den Haag, Staatsuitgeverij $1973 / 1983$.

- Maatschappelijk welzijn kerncijfers 1990. Sociaal-culturele berichten 1990-14.

Fennis HW.JM. Medische demografie voor bejaarden. Bevolking, sterfte, ziekte en invaliditeit. Leiden, NIPG, TNO 1973.

Frederiks CMA. Zorgbehoefte van en zorgverlening aan ouderen. Proefschrift Rijksuniversiteit Limburg, Maastricht 1990.

George LK, Maddox GL. Social and behavioral aspects of institutional care. In: Ory MG, Bond K (eds). Aging and health care. Social science and policy perspectives. Londen/New York, Routledge 1989.

Huijsman R. Model van voorzieningen voor ouderen. Proefschrift Rijksuniversiteit Limburg. Zeist, Kerckebosch bv 1990.

Kam $P$ van der, Mol F, Wimmers MFHG. Beoordelingsschaal voor Oudere Patiënten. Deventer, Van Loghum Slaterus 1971.

Ministerie van WVC. Financieel Overzicht Zorg 1991. Den Haag, Staatsuitgeverij 1990a.

Ministerie van WVC. Ouderen in tel. Beeld en beleid rond ouderen 1990-1994. Den Haag, Staatsuitgeverii 1990b.

Remmen JWM. Bejaardenoordbewoners of verpleeghuispatiënten? Hoogezand, Uitgeverij Stubeg 1985.

Tweede Kamer. Vergaderjaar 1974-1975. Bejaardenbeleid. Den Haag, Staatsuitgeverij 1975. 


\section{HOOFDSTUK 2}

\section{HET VERPLEEGHUIS*}

Margreet JM te Wierik, Carla MA Frederiks 


\section{Inleiding}

Het huidige verpleeghuis is een gezondheidszorginstelling waarin zo'n 50.000 mensen in Nederland zijn opgenomen en zo'n 5.000 enkele dagen per week in dagbehandeling zilin. Het is niet los te zien van de voorzieningen waaruit het is woortgekomen en evenmin van de maatschappelijke ontwikkelingen die tot de huidige vorm hebben geleid. Hoewel het geen specifieke voorziening voor ouderen is, is slechts $6 \%$ van de bewoners jonger dan 65 jaar. De veroudering van de Nederlandse bevolking brengt met zich mee dat steeds meer ouderen langdurige verpleging nodig hebben. Vooral de toename van het aantal ouderen mel dementie maakt dat er steeds meer psychogeriatrische verpleeghuisbedden nodig zijn.

Behalve de geschiedenis van het verpleeghuis en het functioneren ervan komt in dit hoofdstuk ook het huidige beleid rond verpleeghuizen aan de orde.

\section{De geschiedenis van het verpleeghuis*}

In de Middeleeuwen onstonden Gods- of gasthuizen vanuit het diaconale werk van kloosterlingen. In deze, bij kloosters gesitweerde, huizen werd een bonte verscheidenheid van mensen opgenomen: zowel zieken als bejaarden als daklozen konden er terecht. De huidige verpleeghuispatiënten zouden in die tijd, als er thuis geen verzorging voor hen was, in zulke huizen terecht zün gekomen. De nadruk lag niet zozeer op behandeling maar op het verschaffen van onderdak. Pas aan het eind van de vorige eeuw is er enige differentiatie opgetreden en zijn er ziekenhuizen, sanatoria, oude mannen- en vrouwenhuizen te onderscheiden. Na de Eerste Wereldoorlog zijn voor het eerst tehuizen voor langdurig zieken ontstaan die we duidelijk als verpleeg. huizen kunnen beschouwen. Resten van de voorbije tijden zijn hier en daar nog te herkennen. Zo is het huidige Academisch Medisch Centrum ontstaan uit een samengaan van het Wilhelmina- en het Binnenglasthuis. De oudste auteur van dit hoofdstuk (50) kan zich nog de zalen van 40 en meer patiënten herinneren in huizen die zich in een overgangsperiode van het oudeliedenhuis naar een verpleeghuis bevonden. Zelfs na verhuizing naar een nieuw complex gebeurde het nog wel dat verzorgend personeel met 'oppasser' (de officiële aanspreektitel in het voormalige oudeliedenhuis) aangesproken werd!

$\mathrm{Na}$ de Tweede Wereldoorlog is de intramurale ouderenzorg sterk gegroeild. Er kwam steeds meer ordening in de verpleeghuissector en langzamerhand ontstond er overeenstemming over het doel van de verpleeghuizen, de op te nemen patienten en de aard van het personeel. Dit is niet alleen gebeurd door regelgeving van bovenaf, maar ook door een aantal maatschappelijke ontwikkelingen waardoor nieuwe ideeën over ouderen en zorgverlening ontstonden (Remmen 1985; Almekinders 1980).

Een eerste ontwikkeling is de (dubbele) vergrijzing. Vooral het aantal hoogbejaarden neemt toe. Zo waren er in 1950100.000 Nederlanders 80 jaar en ouder, in 1980 312.000 en in 1989 is dit aantal gestegen tot 418.000 (CBS). Met name deze dubbele vergrijzing is belangrijk geweest voor de groei van de intramurale ouderenzorg omdat bij toenemende leeftijd het percentage ouderen dat in een instelling verblijt stijgt
(Huijsman 1989).

Op de tweede plaats zet na de Tweede Wereldoorlog in onze samenleving een aantal ontwikkelingen definitief door. Deze ontwikkelingen waren reeds vanaf het begin van

\footnotetext{
* Deze paragraaf is grotendeels ontleend aan Remmen (1985); waar relevant zijn recentere gegevens
opgenomen.
} 
deze eeuw aan de gang en hebben met name de positie van de oudere in de samenleving sterk gewijzigd. Zo leidde de industriële ontwikkeling tat een scheiding vain de woon-en werksituatie en tot een concentratie van wonen van de werkende bevolking in stedelijke gebieden. Door de wederopbouw na $1945 \mathrm{kwam}$ deze ontwikkeling pas gaed op gang. Hierdoor kwamen niet meer werkende ouderen oak nauweliks meer in contact met werk, terwijl zij vroeger bil aan huis gelegen arbeid, advies konden geven en hand- en spandiensten konden verrichten. Ook kwamen grootouders verder van hun kleinkinderen te wonen: de kinderen trokken naar plaatsen met veel werkgelegenheid. Dit betekende dat de oudere zijn functionele plaats in het uit meerdere generaties bestaande gezin kwijtraakte en ook niet meer binnen een dergelike gezinssituatie kon worden gehuisvest en verzorgd. Deze ontwikkelingen hadden tot gevolg dat, reeds tussen de beide oorlogen in, naast de Gods-en gasthuizen pensiontehuizen van de grond kwamen woor de meer welgestelde ouderen.

Na de Tweede Wereldoorlog werd allereerst een groot aantal nieuwe pensiontehuizen gebouwd. De woningnood van wlak na de oorlog en het idee om woonruimte vrij te krijgen voor degenen die aan het productieproces deelnamen hebben hierbij ook een rol gespeeld hebben.

Een derde ontwikkeling die aanzienlijk theeft bijgedragen tot de uitgroei van de intramurale ouderenzorg is het, op basis van de groeiende welvaart tot stand gekomen, sociale verzekeringsstelsel. Hierdoor werd de intramuralle ouderenzorg ook financieel voor bijna ledere oudere toegankelijk.

Rond 1960 bood de intramurale ouderenzorg een bont beeld. Er bestond een totale huisvestingscapaciteit van 80.000 plaatsen, verdeeld over pensiontehuizen, bejaardenoorden, rusthuizen en verpleeghuizen. Dit betekende dat er op dat moment voor ongeveer $7 \%$ van de ouderen plaatsen in intramurale voorzieningen beschikbaar waren.

Tot na de Tweede Wereldoorlog waren de ontwikkelingen in de intramurale ouderenzorg vrij ongestructureerd verlopen. Hoewel het verpleeghuis reeds in bescheiden mate aanwezig was, was er nog geen systematische scheiding aangebracht tussen verpleeghuizen en verzorgingshuizen. De overheidsbemoeienis met dit veld van zorg was gering en de ontwikkellingen werden voornamelijk door particuliere initiatieven bepaald. In de vijftiger en zestiger jaren kwam hierin duidelijk verandering. De toegenomen belangstelling van de overheid blijkt o.a. uit de rapporten over de ouderenzorg van de Geneeskundige Inspectie uit 1957, 1961 en 1968 en uit de jaarverslagen van de Geneeskundig Hoofdinspecteur over deze jaren. Nog duidelijker komt de toegenomen overheidsbemoeienis met de intramurale ouderenzorg tot uiting via de in 1963 van kracht geworden Wet op de bejaardenoorden. Omdat daarmee voor de bejaardenoorden een specifiek wettelijk kader was geschapen en doordat na de instelling van het Ministerie van Maatschappelijk Werk in 1956 de bejaardenoorden en verpleeghuizen onder verschillende departementen waren gaan ressorteren, vond de verdere ontwikkeling van beide voorzieningen gescheiden plaats. Ook het feit dat het verpleeghuis zich steeds meer als gezondheidszorgvoorziening ging profileren was daarbij van invloed. Het bejaardenoord (tegenwoordig verzorgingshuis genoemd) werd een intramurale maatschappelijke voorziening, die een ondersteunend woonmilieu bood; het verpleeghuis werd een gezondheidszorgvoorziening voor patiënten die well 24 uur per dag medische, paramedische en/of verpleegkundige zorg nodig hadden, maar buiten de specialistische voorzieningen van het ziekenhuis konden. Hieronder wordt verder ingegaan op de ontwikkeling van het verpleeghuis.

De verpleegbehoeftige ouderen verbleven tot de Tweede Wereldoorlog veelal thuis met ondersteuning van huisarts en wijkverpleging. Ook kwam het voor dat ze in ziekenhuizen en psychiatrische centra verbleven. In het Ziekenfondsbesluit van 1942 
werd echter als voorwaarde gesteld dat iemand alleen voor rekening van een algemeen ziekentonds in het ziekenhuis kon worden opgenomen, indien een medisch-specialistische indicatie aanwezig was. Deze eis werd ook door de particuliere ziektekostenverzekeraars overgenomen. Omdat dientengevolge de verpleegbehoeflige bejaarde minder gemakkelijk in ziekenhuizen kon worden opgenomen "ontstond de behoefte aan vervangende voorzieningen. Deze behoefte werd in de eerste jaren na de Tweede Wereldoorlog opgevangen door de inrichting van particuliere verpleeghuisjes met een beperkt aantal bedden, waar patienten veelal op basis van de Armenwet verpleegd werden. De zo ontstane verpleeghuisjes waren te onderscheiden in winstbeogende en niet-winstbeogende instelingen. Met name de laatsten maakten zich sterk voor een verbetering van de kwaliteit van de zorg en gestreefd werd naar een erkenning als aparte gezondheidszorgvoorziening. Daartoe werd mede op initiatief van de Geneeskundige Hoofdinspecteur in 1953 de Federatie van Verpleeginrichtingen opgericht en later de Katholieke Vereniging van verpleeghuizen. De bij deze verenigingen aangesloten verpleeghuizen beheerden in het begin van de vijftiger jaren 1500 verpleeghuisbedden.

Tot 1960 was het verpleeghuis vooral een opvanghuis. De verpleeghuispatiënten waren vaak alleenstaand en axkomstig uit de sociaal zwakkere milieus. Er waren voor hen geen therapeutische mogelijkheden, terwijl terugkeer naar de maatschappij uitgesloten was. Door eerder genoemde ontwikkelingen kanden ouderen nauwelijks meer bij kinderen gehuisvest worden, terwijl er ook nog weinig aangepaste huisvesting voor ouderen was. De opvang was primitief en geschiedde vaak in oude ziekenhuizen en sanatoria, waar patiënten de hele dag in bed lagen. De medische zorg werd verleend door de plaatselijke huisarts. Paramedische diensten en geschoold verpleegkundig personeel waren nilet of nauwelijks aanwezig. Ook was er nog geen scheiding in verpleeghuizen voor somatisch zieken en voor psychogeriatrische patienten.

$\mathrm{Na} 1960$ ontwikkelt het verpleeghuis zich tot een reactiveringsinstituut. Het bieden van vervangende huisvesting staat niet meer centraal, maar de gezondheidszorg die geboden wordt. Voor deze ontwikkeling is een aantal oorzaken aan te wijzen. Allereerst ontstond er door de vooruitgang van de medische wetenschap, en met name ten gevolge van de ontwikkeling van de antibiotica, een nieuwe patientencategorie. Vóór de Tweede Wereldoorlog stierf een patiënt, lijdend aan een chronische degeneratieve ziekte, vrijwel nooit aan de ziekte zelf, maar aan een tijdens deze zlekte optredende infectieuze complicatie. Nu weet men deze infectie te bestrijden. De oorspronkelijke aandoening is evenwel vaak nog niet te genezen, met als gevolg een verdere invalidering. De nieuwe patièntencategorie die zo ontstond was de chronisch zieke, vaak bejaarde patiënt (Michels 1980).

Op de tweede plaats, ontwikkelden zich nieuwe theorieen over de behandeling van de bejaarde patiënt. Schreuder (1966) wees op de gevaren van bedrust en inactiviteit en pleitte voor een actieve behandeling van de geriatrische patiënt. De ADL-index (ADL = Activiteiten van het Dagelijks Leven), die in de Verenigde Staten was ontwikkeld als meetinstrument voor de zorg aan de chronisch zieke en bejaarde patient (Katz 1963), werd o.a. door Leering (1968) in de Nederlandse verpleeghuiswereld
geintroduceerd.

Tenslotte was in het ziekenhuis, dat door de verdergaande technologische ontwikkelingen uitgroeide tot een medisch-specialistisch instituut, voor de chronisch zieke
patient steeds minder plaats.

De consequenties van deze ontwikkelingen worden beschreven in drie adviezen die in de periode van 1966-1972 door de Centrale Raad voor de Valksgezondheid over het verpleeghuis zijn uitgebracht. Ze komen het duidelijkst tot uiting in de personele 
bezetting van het verpleeghuis. Zo komen er vaste verpleeghuisartsen. Verder doen de paramedische disciplines (eerst de fysiotherapie, later de logopedie en de ergo. therapie) hun intrede in het verpleeghuis. Hetzelfde geldt voor de maatschappelijk werkende en de psycholoog. Naast de verpleegkundige komt er een nieuwe groep verzorgenden, die in het verpleeghuis zelf wordt opgeleid. Vanaf 1965 is het diploma van deze ziekenverzorgenden wettelik beschermd.

In dezelfde periode treedt ook een differentiatie op in verpleeghuizen voor somatisch zileken en voor psychisch gestoorde bejaarden.

Deze nieuwe ontwikkeling werd tevens geaccentueerd in een naamsverandering die het verpleeghuis in deze periode onderging. De Centrale Raad voor de Volksgezondheid sprak in 1972 in haar 'Advies over de nomenclatuur voor inrichtingen van gezondheidszorg' uit, dat beter van 'verpleeghuizen" dan van 'verpleegtehuizen' kon worden gesproken, omdat de inrichting primair een behandelingsinstituut is en er naar wordt gestreefd een behandeling, indien mogelikk, van tijdelijke aard te doen zijn. Ook ten aanzien van de bekostiging van opname in het verpleeghuis kwam meer duidelijkheid. Vanaf 1961 namen de ziekentondsen voor ziekentondsverzekerden de helft van de kosten van een verpleeghuisopname gedurende 3 maanden voor hum rekening. In 1968 werd de Algemene Wet Bijzondere Zliektekosten ingevoerd en werd de verpleging in het verpleeghuis een verstrekking in het kader van deze wet. Om voor vergoeding van kosten in aanmerking te komen, moest een verpleeghuis erkend worden in het kader van deze wet, hetgeen een nieuwe mogelijkheid verschafte om aan de verpleeghuizen kwaliteitseisen te stellen. De verpleegprijs per dag werd vanaf die tilid door het Centraal Orgaan Ziekenhuistarieven, het huidige Centraal Orgaan Tarieven Gezondheidszorg, vastgesteld. Sedert 1 janulari 1984 is er voor de verpleeghuizen een systeem van budgetfinanciering ingevoerd.

Vanaf 1971 valt de planning van de verpleeghuizen onder het regime van de Wet Ziekenhuisvoorzieningen (WZV), die toen gedeeltelijk werd ingevoerd. Vanaf deze tijd was het niet meer mogelijk om een verpleeghuis te exploiteren, te bouwen of te verbouwen zonder toestemming van de betreffende minister. Alvorens over een bouwplan te beslissen won de minister advies in bij het betreffende provinciaal bestuur en het College voor Ziekenhuisvoorzieningen in Utrecht.

In 1979 werd een gewijzigde WZV van kracht, waarin aan de provinciale besturen werd opgedragen om de planning van de verpleeghuizen in hun provincie zelf ter hand te nemen. In het kader van artikel 3 van de wet werd een aantal richtlijnen ontworpen, waarmee bij de planning rekening zou moeten worden gehouden. Zo werd vastgesteld dat het aantal bedden in verpleeghuizen voor somatisch zieken $1,2 \%$ van de leeftijdsgroep 65 jaar en ouder zou mogen bedragen, vermeerderd met 0,35 promille van de totale bevolking. Het verpleeghuis is er dus niet alleen voor ouderen, ook jongere patiënten worden er opgenomen, zij het in kleine alantallen. Voor verpleeghuisbedden voor psychogeriatrische patiënten bedraagt deze norm $1,25 \%$ van de leeftijdsgroep 65 jaar en ouder. Tevens werden er richtijnen aangegeven voor de minimale en maximale omvang van verpleeghuizen (zie schema 1). Om uniformiteit te krijgen in de beoordeling van bouwplannen werden in 1981 door het College voor Ziekenhuisvoorzieningen beoordelingsmaatstaven ontwikkeld voor bouwplannen in de verpleeghuissector (College voor Ziekenhuisvoorzieningen 1981). Met al deze ontwikkelingen groeide het aantal verpleeghuizen in Nederland van 90 verpleeghuizen met in totaal 6300 bedden in 1960 naar 324 verpleeghuizen met 50.571 bedden in 1989 (Ministerie van WVC 1989).

Omdat de AWBZ een volksverzekering is, heeft iedereen recht op het verstrekkingenpakket van deze verzekering. Bij de invoering van de Wet in 1968 was dit uitgangs* 


\section{Schema 1. CAPACITEITSBEGRENZING VAN VERPLEEGHUIZEN}

Een verpleeghuis kent de volgende capaciteitsbegrenzing.

In beginsel dient:

de capaciteit van een gecombineerd verpleeghuis ternminste 150 bedden te bedragen.

waarbij geldt dat geen var beide sectoren minder dan 60 bedden heeft;

- de capaciteit van een niet-gecombineerd verpleeghuis tenminste 90 bedden te bedragen:

- als maximum capaciteit voor een gecombineerd verpleeghuis een grens van 210 bedden te worden aangehouden;

- als maximum capaciteit voor een enkelvoudig verpleeghuis een grens van 180 bedden te worden aangehouden.

Deze getallen gaan uit van eenheden wan 30 bedden. Bovenstaande capaciteitsbegrenzingen gelden in beginsel slechts voor situaties waarin nieuwbouw wordt overwogen.

Eron: Ministerie van WVC 1986

punt voor de verpleeghuiszorg nog niet haalbaar, omdat er een tekort was aan verpleeghuisbedden, terwijl ook een aantal verpleegbehoeftigen in niet erkende verpleeghuizen verbleef. Om dit onrecht op te heffen werd op 1 oktober 1971 de " 1 -oktober regeling" ingevoerd, die het mogelijk maakte dat verpleegbehoeftigen ook in bejaardenoorden en in niet erkende verpleeghuizen op kosten van de AWBZ kanden worden verpleegd. Omdat het tekort aan verpleeghuisbedden volgens de norm langzamerhand is opgeheven, en er twijfels bestaan over de kwaliteit van de zorgverlening, zoals die in bejaardenoorden en niet erkende verpleeghuizen wordt verstrekt, wordt deze " 1 oktober-regeling' momenteel afgebouwd. Op "1 januari 1981 waren er nog 2.368 zogenaamde 1 -oktoberbedden; in 1988 waren er nog slechts 529 (Ministerie van WVC 1989).

Ondat ook in de verpleeghuiswereld de gedachte steeds meer ingang vond dat de patiënt zoveel mogelijk in zijn eigen omgeving gehandhaafd dient te worden, werd in 1977 de mogelijkheid tot dagbehandeling in verpleeghuizen ingevoerd. De bedoeling van deze dagbehandeling was om opname in het verpleeghuis te verminderen of uit te stellen en om het ontslag uit het verpleeghuis te bespoedigen. Men hoopte via dagbehandelling een ontiasting van het thuismilieu te bewerkstelligen, waardoor de patient langer thuis zou kunnen worden verzorgd. De norm werd gesteld op $6 \%$ van het aantal toegestane bedden. Sinds kort is het ook mogelijk om ten koste van eén verpleeghuisbed, twee extra dagbehandelingsplaatsen te openen. In 1989 beschikten 201 verpleeghuizen over een afdeling dagbehandeling met in totaal 2931 dagbehandelingsplaatsen (Ministerie van WVC 1989).

Na de stormachtige ontwikkelingen treedt aan het eind van de zeventiger jaren een periode van bezinning in, die nog steeds gaande is. Binnen de verpleeghuiswereld komt de vraag naar voren of men eigenlijk wel op de goede weg is. Centraal in deze discussie staat het gebrek aan privacy van de verpleeghuispatiënt en zijn geringe zelfstandigheid. Als katalysator voor deze discussie kunnen o.a. het proefschrift van ten Have (1979) worden genoemd en de ideeën die Hattinga Verschure (1980) ontwikkelde over de zorgverlening aan de verpleeghuis-patiënt. Van bezinning is ook sprake in de discussienota "Taak en functie verpleeghuizen' van de Nationale Ziekenhuisraad, die in 1981 verscheen en in het 'Interimadvies inzalke het functioneren van verpleeghuizen' van de Centrale Raad voor de Volksgezondheid uit "I982. Beide rap-
porten zijn in zoverre teleurstellend, dat zij zich beperken tot de inventarisatie van de 
huidige verpleeghuiszorg en de knelpunten hierin. Elementen van vernieuwing worden niet aangedragen.

De behoefte aan het onderbouwen wan de zorgverlening in verpleeghuizen maakte dat in 1980 voor het eerst een hoogleraar verpleeghuisgeneeskunde aangesteld werd. Het idee dat het in de verpleeghuiszorg anders zou moeten blifkt ook uit de belangstelling die er op dit moment bestaat voor de opvang van de verpleegbehoeftigen in de ons omringende landen, met name in Scandinavië waar Kleinschalige verpleeghuizen de voorkeur hebben. Een complicerende factor bil al deze vernieuwingen is echter dat zij ontwikkeld moeten worden in een tijd waarin de financieile ruimte vrij beperkt is.

\section{De functie van het verpleeghuils}

De verpleeghuizen in Nederland worden onderscheiden in huizen voor somatische en huizen voor psychogeriatrische (p.g.) patiënten. In tabell 1 staat een aantal gegevens over deze huizen vermeld.

Tabel 1. Verpleeghuizen in Nederland in 1988

Soort Verpleeghuis

Aantal

112

Somatisch

Gecombineerd

Psychogeriatrisch
135

77
Aantal bedden

Dagbehandeling
1.600 plaatsen

1.300 plaatsen

Bron: Ministerie van WVC 1989

\section{De somatische patiënten}

Binnen de groep somatische patiënten, waarbij lichamelijke aandoeningen op de voorgrond staan, worden reactiveringspatiênten, chronische en terminale patiënten onderscheiden.

De reactiveringspatiënten worden vaak vanuit het ziekenhuis opgenomen. Na een acuut incident zoals een heupfractuur of een hersenbloeding waarvoor de patiënt in het ziekenhuis opgenomen werd, komt een periode waarin de patiënt de intensieve zorg van het ziekenhuis niet meer nodig heeft, maar ook nog niet optimaal hersteld is. Het behandeldoel is dan ook de patiënt zover te reactiveren dat hij terug kan naar de eigen woonomgeving of naar een verzorgingshuis. Hierbij worden fysiotherapie en ergotherapie aangeboden en indien nodig ook logopedie. Met de maatschappelijk werkende wordt de thuiskomst woorbereid. Extramurale hulp en aanpassingen in het huis die soms noodzakelijk zijn, worden geregeld. Ook wordt, indien nodig, bemiddeld voor een plaats in een verzorgingshuis.

De gemiddelde leeftijd van deze patiënten bij opname is 78,4 jaar. Na een verbliff van gemiddeld bijna 9 maanden wordt $42 \%$ inderdaad naar huis ontslagen en $15 \%$ naar een verzorgingshuis. Bij ongeveer $40 \%$ wordt het gestelde behandeldoel niet bereikt: $33 \%$ overlijdt in het verpleeghuis en $7 \%$ wordt ontslagen naar het ziekenhuis (schema 2a). 
De chronische patiënten hebben lichamelijke handicaps die (verder) verblijf in de thuissituatie of het verzorgingshuis onmogelijk maken. Wanneer dit punt bereikt is hangt witeraard ook van de sociale situatie van de patiënt af. Hoeveel zorg kan door de mensen die hem omringen nog opgebracht worden?
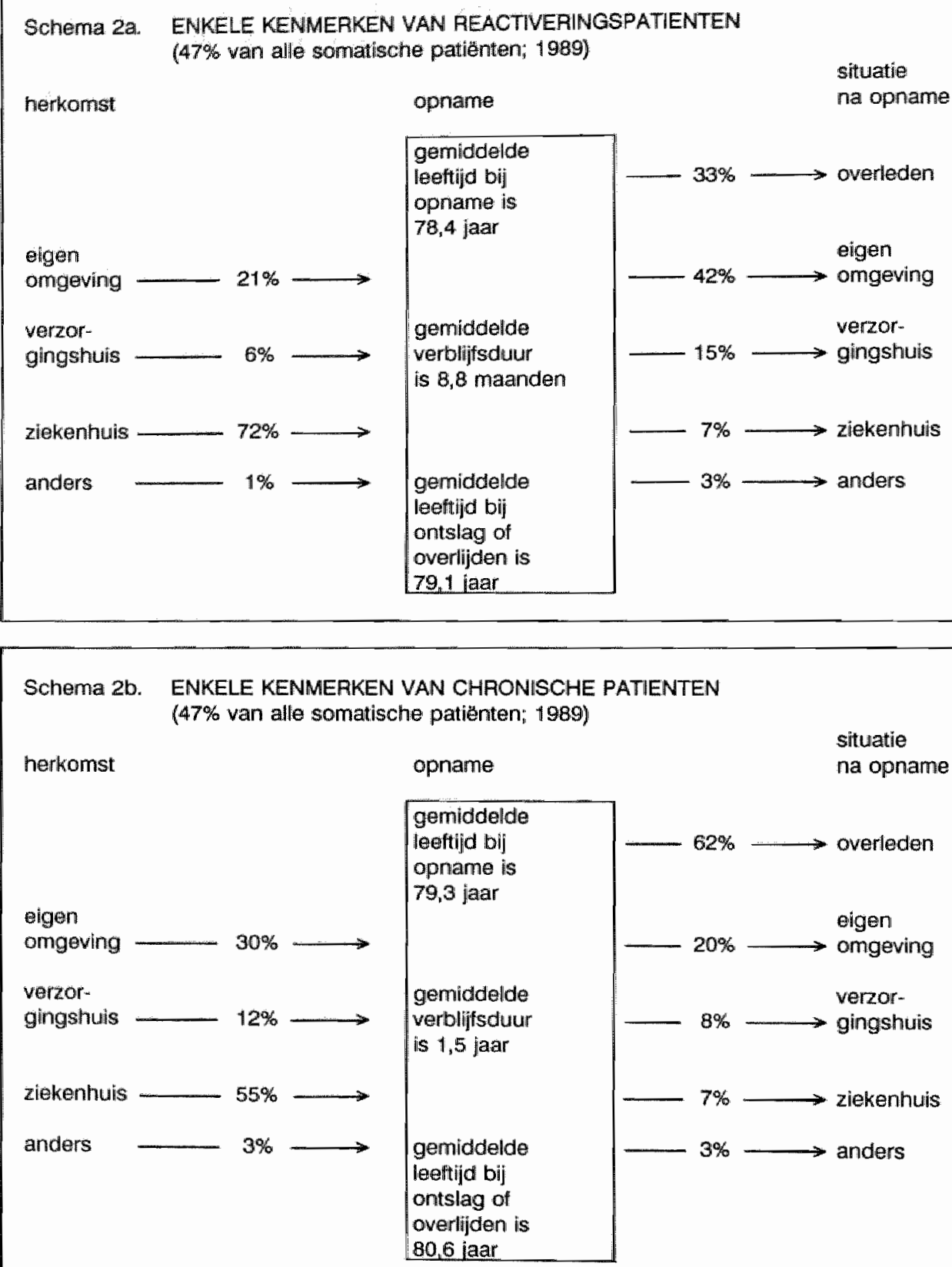

Bron: SIG Verpleeghuisinformatiesysteem $1990^{1,2}$ 
Chronische patiënten verblijven vaak lang in het verpleeghuis. Er wordt dan ook vaker van verpleeghuisbewoners in plaats van patiënten gesproken. Het behandeldoel vool" deze categorie is het zo lang mogelijk op peil houden van de nog aanwezige functies. Tevens wordt getracht een nadruk op de woonfunctie van het huis te leggen. In veel huizen wordt toegelaten dat wat dierbare bezittingen zoals een schilderij, een lamp en een makkelijke stoel de verpleeghuisomgeving wat huiselijker maken. Ook worden, naast fysiotherapie e.d. creatieve en sociale activiteiten aangeboden.

De gemididelde leeftijd van deze patiënten bij opname is 79,3 jaar. Na een verblijf van gemiddeld anderhalf jaar is ruim $60 \%$ van deze groep overleden; bijna $30 \%$ wordt toch nog naar huis of naar een verzorgingshuis ontslagen (schema 2b).

De terminale patiënten komen in het verpleeghuis om te sterven. Zij zijn zowel uit het ziekenhuis als uit de thuissituatie en het verzorgingshuis afkomstig. Het behandeldoel is het verlichten van lijden. Behalve medicatie wordt ook wel fysiotherapie gegeven om bijvoorbeeld benauwdheid te verminderen. Ook wordt veel aandacht besteed aan de geestelijke begeleiding van deze patiënten en hun naasten.

Bij opname zijn deze patiënten gemiddeld 76,9 jaar. Na een kort verblijf van gemiddeld 4 maanden overlijdt $95 \%$ van deze patiënten inderdaad in het verpleeghuis (schema 2c).

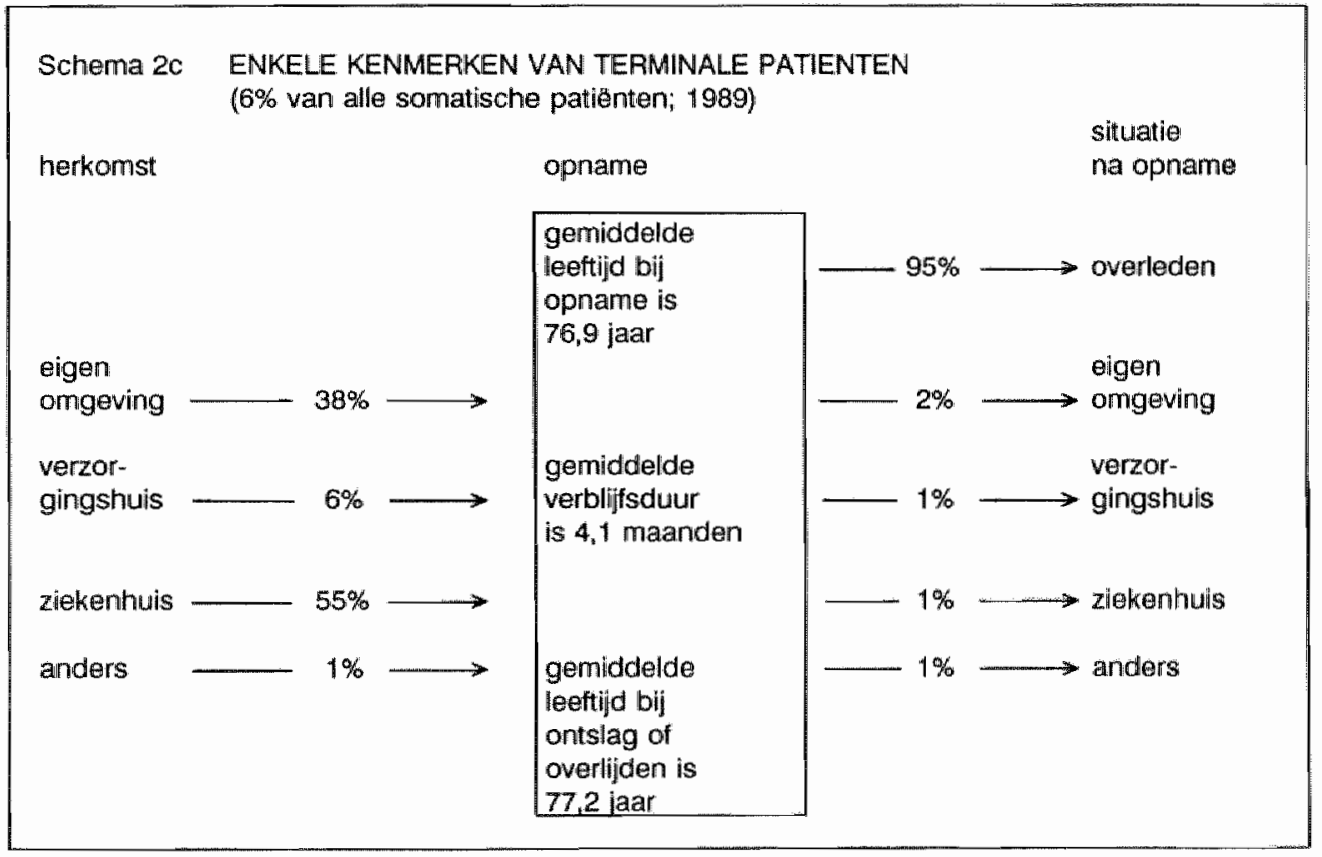

Bron: SIG Verpleeghuisinformatiesysteem $1990^{1,2}$

\section{De psychogeriatrische patiënten}

De patiënten die worden opgenomen op p.g. afdelingen worden gekenmerkt door gedragsstoornissen. Hoewel bij driekwart van hen de diagnose dementie gesteld is en bij 20 'n $12 \%$ de diagnose amnestisch syndroom (SIG 1989), kunnen de gedragsstoornissen nogal in hevigheid wisselen. Er komt desoriëntatie in tijd "plaats en persoon voor. De vroege herinnering is vaak nog lang intact; het recente geheugen veel minder: men prent nauwelijks meer in. Bij redelijk goede patiënten worden de 
'gaten' in het geheugen soms met zelfverzonnen verhalen (confabulaties) gedicht. Zo verbergt of dissimuleert men de eigen klachten. Bij patiënten die al wat verder achteruit gegaan zijn kan acute verwarring soms omslaan in agressie. Men moet weg, de kinderen moeten uit school gehaald, de koeien moeten gemolken enz. zijn bekende beelden. Men wantrouwt de omgeving, die hen deze activiteiten niet toestaat. Deze achterdocht of paranoïdie uit zich soms in het verstoppen van dierbare zaken "die door gebrek aan inprenting ook voor de patiènt zelf onvindbaar worden en daardoor het wantrouwen versterken.

De meeste patiënten met dementie in een vergevorderd stadium herkennen geen mensen meer uit hun omgeving en weten niet meer wie zij zelf zijn. Er komt onder her veel apathie voor, maar ook stereotiep gedrag zoals rommelen, frummelen en steeds hetzelfde zingen, zeggen of vloeken. In het laatste stadium is men geheel gedesoriënteerd in tijd, plaats en persoon en leidt men een vegeterend bestaan.

Schema 2d. ENKELE KENMERKEN VAN PSYCHOGERIATRISCHE PATIENTEN (29\% van alle verpleeghuispatienten; 1989)

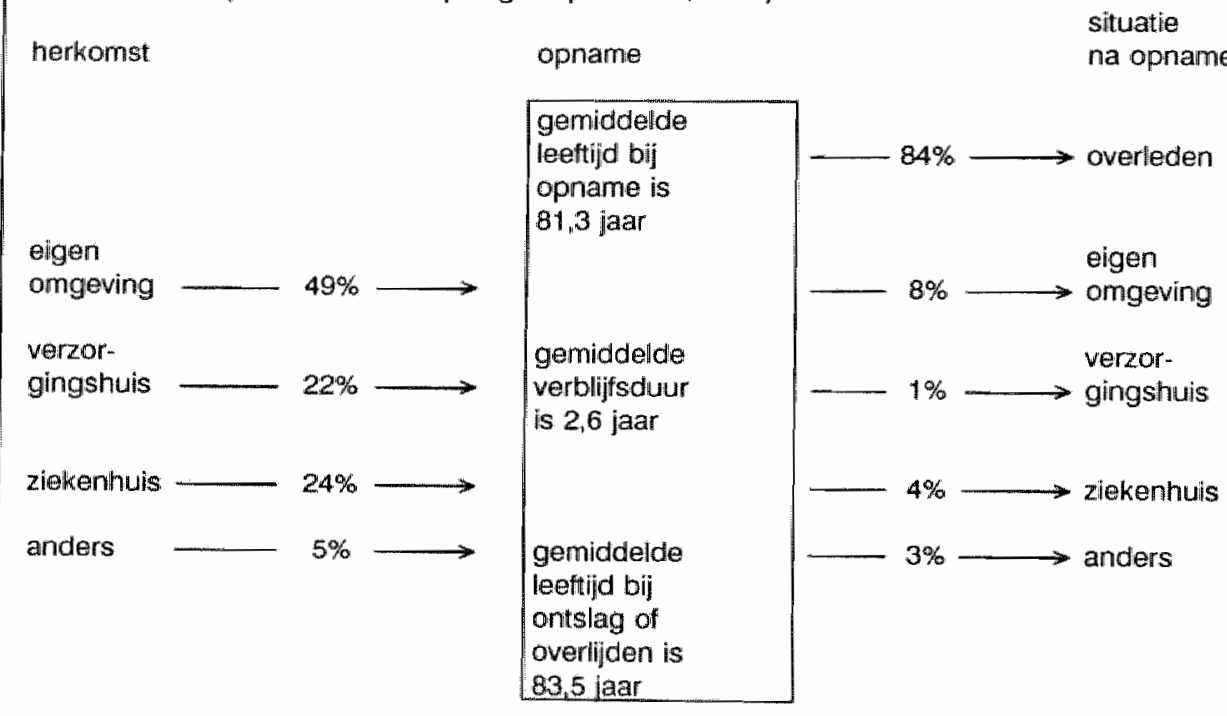

Bron: SIG Verpleeghuisinformatiesysteem $1990^{\prime}$

Bijna de helft van de psychogeriatrische patiënten wordt vanuit de eigen omgeving in het verpleeghuis opgenomen; zo'n 20\% woonde voordien in een verzorgingshuis. De gemiddelde leeftijd bij opname is 81,3 jaar. Meer dan $80 \%$ van deze patiënten overlijdt in het verpleeghuis, na een verblijf van gemiddeld ruim twee en een half jaar (schema 2d).

In een aantal verpleeghuizen streeft men ernaar de p.g. patiënten naar de ernst van hun aandoening op verschillende afdelingen te verplegen. Men differentieert dan begeleidingsbehoeftige, verzorgingsbehoeftige en verplegingsbehoeftige patiënten. Soms is er een observatie-afdeling waar de mogelijkheden van de patiënt geinventariseerd worden en van waaruit dan plaatsing op een van de afdelingen plaatsvindt. Ook wordt een patiënt voor opname nog well eens op een GAAZ (Geriatrische Afdeling van een Algemeen Ziekenhuis) uitvoerig onderzocht voordat tot plaatsing in een verpleeghuis wordt overgegaan. Een depressie, een verkeerde medicatie of een 
somatische ziekte kunnen soms gedragsstoomissen oproepen die dementie-patienten vertonen. Het is duidelijk dat voor die patiênten andere behandelvormen openstaan en plaatsing op een p.g. afdeling van een verpleeghuis ongewenst is. Uit onderzoek komt naar voren dat van de patienten, die zonder specialistisch consult door de huisarts aangemeld werden voor een plaats op een p.g. afdeling. 35 procent na screening door een multidisciplinair team reversibele gedragsstoornissen had. Bilj deze groep kon met een lichtere vorm van zorg (verzorgingshuis, aanleunwoning, thuis zorg) worden volstaan (Claessens 1984). Aan het echte dementie-syndroom is weinig te doen. Men kan proberen door stimulatie de achteruitgang te vertragen. Er wordt wel gewerkt met Realiteits- en Oriëntatie Training (ROT) waarbij men probeert de omgeving van de patiënt zo herkenbaar mogelijk voor hem te maken en door steeds weer opnieuw inprenten toch wat restfuncties te stimuleren. Het geeft het personeel in ieder geval houvast om toch gericht met de patiënten bezig te zijn. Op het ogenblik is de Validation therapie erg in opkomst waarbij men de patiënt bekrachtigt (vallideert) in bestaande restfuncties. Bezigheden die men vroeger goed beheerste (sokken breien, koken, dieren verzorgen enz.) worden aan de patiënten aangeboden. De patiënten worden er niet beter van, maar lijken zich bij deze vertrouwde bezigheden rustiger te voelen, waardoor onrust en agressie vermeden kan worden en het gedrag meer aangepast wordt (Fleischeuer en Van der Kooij 1989). Overigens is naar de effecten van beide therapieën nog geen goed onderzoek gedaan. Met de dubbele vergrijzing en de daarmee gepaard gaande toename van dementie wordt dat de hoogste tijd. De ruimtelijke omgeving kan de patiënten veel bieden. Patiënten die zwerfineigingen hebben worden vaak erg onrustig wanneer zij op een gesloten afdeling verpleegd worden. Een architectuur met afdelingen rondom gesloten binnentuinen geeft deze ouderen bewegingsvrijheid zonder dat gevaar voor weglopen ontstaat. De verpleeghuizen Nieuw Toutenburg in Friesland, Casa Bonita in Apeldoorn en de Zeven Bronnen in Maastricht zijn hier voorbeelden van (zie figuur 1).

Om het beloop van de dementie te volgen wordt het gedrag van de p.g. patiënten regelmatig met behulp van gedragsobservatieschalen geïnventariseerd. De bekendste schaal die gebruikt wordt is de BOP, Beoordelingsschaal Qudere Patiënten, die zes gedragsaspecten inventariseert, namelijk hulpbehoevendheid, agressiviteit, lichamehijke invaliditeit, depressief gedrag. psychische invaliditeit (oriëntatie- en communicatiestoornissen) en inactiviteit (Van der Kam et al. 1971). De schaal wordt tevens toege. past om effecten van bepaalde medicijnen of therapieën te meten. Ook wordt de schaal well gebruikt als hulpmiddel bij het plaatsen van p.g. patiënten op afdelingen voor begeleidingsbehoeftige, verzorgingsbehoeftige of verplegingsbehoeftige patiënten. De BOP-score is niet alleen indicatief voor de toestand van de patient; er wordt hiermee ook informatie verkregen over de werklast van het personeel. Wanneer bepaalde therapieën een meer aangepast gedrag bil p.g. patiënten teweeg zouden brengen, is niet alleen de patiënt maar ook het personeel hiermee gebaat (Diesfeldt $1981)$.

Een andere schaal die momenteel in opkomst is, is de GIP. de Gedragsobservatieschaal voor de Intramuralle Psychogeriatrie (Verstraeten en Van Eekelen 1987). De GIP inventariseert zelfs 14 gedragsaspecten. Hierdoor is de schaal informatiever, maar de invulling ervan is tijdrovender. In een verpleeghuis in Amsterdam vulde het verzorgende personeel in ruim zeven minuten een BOP-lijst in, terwijl het invullen van de GlP-lijst bijna 20 minuten in beslag nam (Melchior 1990). De meerwaarde van de GIP boven de BOP dient daarom nog eens kritisch bekeken te worden.

Wanneer de toestand van een patiënt dermate verslechtert dat hij storend is voor de afdeling kan tot overplaatsing naar een zwaardere afdeling besloten worden. 


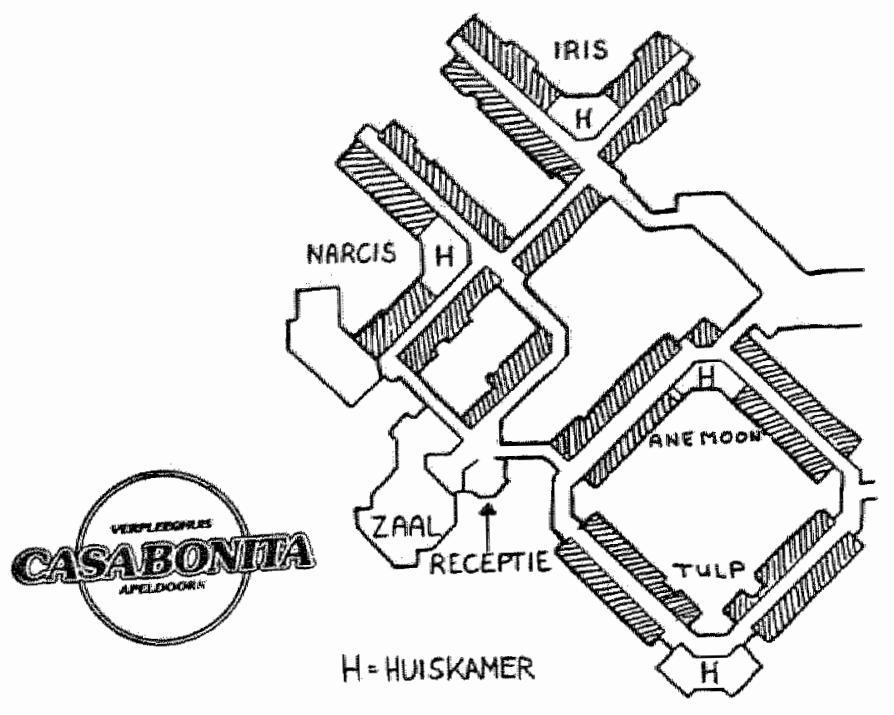

Figuur 1. Bouwkundige opzet van het verpleeghuis Casa Bonita in Apeldoorn

\section{De opname in een verpleeghuis}

Het verblijf in een verpleeghuis wordt gefinancierd door de AWBZ en tot januari 1989 diende opname in een verpleeghuis bij de AWBZ-ambtenaar aangevraagd te worden. Vanuit het ziekenhuis werd deze aanvraag door de behandelend specialist gedaan, vanuit de thuissituatie of het verzorgingshuis door de huisarts. Bil een spoedopname werd de aanvraag vaker na de eigenlijke opname gedaan en werd achteraf getoetst of deze terecht had plaatsgevonden.

Bij de opname van de patiënten zijn doorgaans een maatschappelijk werkende, een verpleegkundige/ziekenverzorgende en een verpleeghuisarts betrokken. De patiënt en zijn familie worden door hen voorbereid op de opname. Bij verpleeghuizen met gedifferentieerde afdelingen overlegt het verpleeghuispersoneel dat bij de opname betrokken is, op welke afdeling de patient het meest op z'n plaats is. Het komt helaas vaak voor dat de patiënt op de wachtlijst voor opname geplaatst moet worden. Zo bleek in 1987 in $85 \%$ van de verpleeghuizen een wachtlijst te bestaan. De gemiddelde wachttijd bedroeg \pm 7 weken voor somatische patiënten en maar liefst 25 weken voor p.g. patienten (Spaan 1989). Het grote tekort aan vooral p.g. bedden wordt hiermee duidelijk geillustreerd.

Sinds 1 januari 1989 is er een nieuwe opnameregeling van kracht. De taak van de indicatiecommissies voor de bejaardenoorden werd aanzienlijk uitgebreid doordat ook de indicatiestelling voor verpleeghuizen tot hun taak ging behoren. Deze regeling werd nogal abrupt in september 1988 aangekondigd met als gevolg dat deze nieuwe regeling vertraagd en soms gedeeltelijk werd ingevoerd. De verschillende verzorgingsgebieden van beide instellingen, alsmede competentieproblemen tussen leden vari de commissie en van de instellingen, zijn oorzaken geweest van deze vertraging. Een voordeel van de nieuwe indicatiecommissie is dat voor een aanvrager het beste zorgaanbod gerealiseerd kan worden. Voor sommige verzorgingshuisaanvragers kan een verpleeghuisopname zinnig zijn wanneer er reële reactiveringsmogelijkheden aan- 
wezig zijn. Ook bestaat de mogelijkheid dat een potentiele verpleeghuispatiënt toch nog uitkomt met het zorgaanbod van een verzorgingshuis, met als voordeel dat hij in een veel huiselijker omgeving terecht komt.

Ook financieel is er momenteel voor de aanvragers een betere afstemming tussen de twee voorzieningen. Hoewel de twee voorzieningen nog uit verschillende bronnen gefinancierd worden, is er ook voor het verpleeghuis een vergelikbare inkomensalhankelijke bijdrage ingesteld die op kan lopen tot $f 2.200$ - per maand. Het is te verwachten dat de financiering in de toekomst door één instantie verricht wordt en dat er dan voor toekomstige bewoners geen verschil meer zall zijn in de eigen bijdragen aan de voorzieningen. Wel zal uiteraard het verschil in kosten - een dag in een verpleeghuis kostte in 1988 gemiddeld $f 203_{1}-;$ dit bedroeg $f 84_{1}$ - voor het verzorgingshuis * bliven bestaan (Ministerie van WVC 1989).

\section{Dagbehandeling}

Naast de intramurale zorg biedt het verpleeghuis zoals al vermeld ook semimuralle zorg in de vorm van dagbehandeling. Deze zorg kan zowel aan somatische als aan p.g. patiënten geboden worden. Dagbehandelingspatiënten zijn patiënten die in principe in aanmerking komen voor opname in een verpleeghuis maar waarbij het thuismilieu nog zoveel ondersteuning biedt dat de zorg niet 24 uur per dag nodig is. In principe worden dezelfde therapieën en zorg aangeboden als bij de intramurale zorg. Uit verschillend onderzoek, dat voornamelijk inventariserend en exploratief van karakter is, komt echter naar voren dat de dagbehandeling lang niet altijd de aanvankelijk verwachte effecten bereikt (Nies 1986). Vervroegd ontslag uit het ziekenhuis of verpleeghuis door dagbehandeling komt bij somatische patiënten in beperkte mate voor: bij P.g. patiënten niet of nauwelijks. Bij een deel van de somatische patiënten wordt opname vermeden, bij een deel van beide categorieën patiënten is sprake van uitstel van opname. Substitutie blijkt wat meer plaats te vinden bilj somatische dan bij p.g. patiënten, maar in beide categorieën betreft het een minderheid. Het lijkt er dan ook sterk op dat dagbehandeling grotendeels een nieuwe categorie patiënten heeft aangetrokken. Omdat dagbehandeling vaak gevolgd wordt door een opname lijkt het erop dat deze voorziening veelal als wachtkamer voor de verpleeghuisopname gebruikt wordt. Overigens is dit, gezien de lange wachttijden, niet verwonderlijk. Als positieve effecten van de dagbehandeling komen naar voren dat het sociaal-relationeel functioneren van de patiënt vaak verbetert en dat de verzorgers thuis, ook de professionele, een aanzienlijke taakverlichting en ondersteuning ervaren. Een moeilifke situatie thuis kan hierdoor langer volgehouden worden. Ondanks de teleurstellende substitutie resultaten lijkt hierin momenteel de legitimering van de dagbehandeling te liggen, mede door tekort aan bedden (Nies 1986).

In 1989 waren van de 2.931 dagbehandelingsplaatsen er zo'n $45 \%$ bestemd voor p.g. patiënten. Doordat de meeste patiënten $(90 \%) 2$ a 3 maal per week de dagbehandeling bezoeken kunnen meer mensen gebruik maken van een plaats (gemiddeld per plaats drie patiënten per jaar, Spaan 1989). Dit betekent dat zo'n 8800 mensen per jaar van deze zorg gebruik maken.

\section{Het personeel in verpleeghuizen}

In tabel 3 is het aantal werkenden in verpleeghuizen weergegeven. Met uitzondering van stagiaires zijn alle werkenden in loondienst, ook de artsen en het paramedisch personeel. 


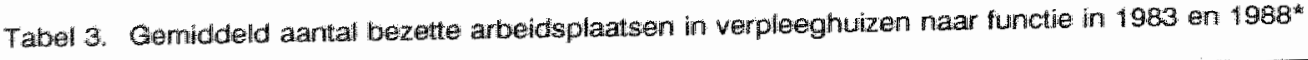

\begin{tabular}{|c|c|c|c|}
\hline & 1983 & 1988 & $\begin{array}{l}\text { gemiddelde } \\
\text { jaartijkse } \\
\text { groei in \%* }\end{array}$ \\
\hline Algemeen personeel & 12.334 & 13.296 & 1,5 \\
\hline $\begin{array}{l}\text { Gediplomeer } \text {, leering- } \\
\text { en ander verpleegkundig } \\
\text { personeel }\end{array}$ & 31.603 & 35.809 & 2,5 \\
\hline $\begin{array}{l}\text { Medisch en paramedisch } \\
\text { hulpparsoneel }\end{array}$ & 3.730 & 4.331 & 3,0 \\
\hline $\begin{array}{l}\text { Medisch en sociaal- } \\
\text { wetenschappelijke staf }\end{array}$ & 496 & 647 & 5,5 \\
\hline $\begin{array}{l}\text { Overig (stagiaires; niet } \\
\text { in loondienst) } \\
\text { Totaal }\end{array}$ & $\begin{array}{r}1.387 \\
49.550\end{array}$ & $\begin{array}{r}2.786 \\
56.869\end{array}$ & $\begin{array}{r}15,0 \\
2,8\end{array}$ \\
\hline
\end{tabular}

- Uitgedrukt in full-time equivalenten, niet gecorrigeerd voor ATV-effekt

1) Bijv. doktersassistenten, fysio-en ergotherapeuten

2) Met name artsen en psychologen

Bron: Ministerie van WVC 1989

Uitgedrukt in personeel per bed varieerde in 1988 het aantal personeelsleden per 100 bedden van 107 in p.g. verpleeghuizen tot 115 in gecombineerde verpleeghuizen (Ministerie van WVC 1989).

De aantallen in tabel 3 zijn uitgedrukt in fte's. Omdat er veel parttime gewerkt wordt in verpleeghuizen is het absolute aantal werkenden in verpleeghuizen groter. De laatste jaren is het aantal parttimers sterk gestegen; sinds 1987 zijn er zelfs meer parttimers dan fulltimers werkzaam (Spaan 1989).

De grootste groep werkenden wordt uiteraard gevormd door het gediplomeerd, leerling en ander verpleegkundig personee ${ }^{\star}(63 \%)$. De verhouding gediplomeerd en ander verpleegkundig personeel (0.a. verpleeghulpen) ten opzichte van leerling verpleegkundig personeel is 70/30. Het merendeel van het verpleegkundig en verzorgend werk wordt door ziekenverzorgenden gedaan. De weinige verpleegkundigen die er werken hebben vaak leidinggevende functies zoals afdelingshoofd.

Een tweede grote groep is het algemeen personeel. Zij doen het huishoudelijke, administratieve en onderhoudswerk. Tot de groep medisch en paramedisch personeel behoren de verpleeghuisartsen, fysio-, ergo- en creatieve therapeuten en logopedisten.

In de afgelopen jaren is het aantal arbeidsplaatsen in verpleeghuizen iets toegenomen (reële groei $1,2 \%$ in de periode 1984-1988). Deze toename is echter te gering om de sterker toegenomen hulpbehoevendheid van de patiënten op te vangen. Zo zijn bijna alle bewoners ADL-afhankelijk. De ziekenverzorgenden en verpleegkundigen hebben dan ook een zwaar en druk beroep. Omdat zij naast de ADL-ondersteuning en verpleegkundige zorg vaak ook nog behulpzaam zijn bij de diverse therapieën is de werklast groot. Het werk is niet alleen lichamelijk zwaar, ook psychisch wordt het nodige geëist. De dagelijkse confrontatie met lijden en docd alsmede het machteloos

* inclusief ziekemverzorgenden 
toezien dat patiënten steeds meer achteruitgaan of verder verward raken legt een zwaar beslag op het moreel.

\section{Het huidige beleid}

Het huidige beleid rond verpleeghuizen kan niet los gezien worden van andere zorgvoorzieningen. In de diverse beleidsnota's zijn globaal vier uitgangspunten te herkennen die wij hieronder toelichten.

\section{Substitutie binnen de tweede lijn}

Binnen de tweede lijn streeft men ernaar de zorg op de minst kostbare plaats aan te bieden. Er is een duidelijk streven om patienten vanuit het ziekenhuis te ontslaan naar het verpleeghuis, zodra de intensieve ziekenhuiszorg miet meer nodig is. Hierdoor komen revalidatie patiënten maar ook terminale patiënten vanuit het ziekenhuis in het verpleeghuis terecht. De laatste jaren is de gemiddelde opnameduur in het ziekenhuis daadwerkelijk verkort en zijn er steeds meer verpleeghuispatiënten afkomstig uit het ziekenhuis. Verbleef in $197032 \%$ van de patiènten voor de verpleeghuisopname in een ziekenhuis, in 1987 is dit tot toegenomen tot 55\% (Wimmers 1976; SIG 1988). De hiermee gepaard gaande kostenbesparingen zijn minder dan men wellicht op het eerste gezicht zou denken. Deze substitutie betekent dat relatief lichte ziekenhuispatiënten zware verpleeghuispatiënten worden. Het gevolg hiervan is dat de opgenomen patiënten in beide voorzieningen meer zorg, zowel medisch, paramedisch als verpleegkundig, behoeven. Door deze vorm van substitutie worden beide voorzieningen dus duurder.

Een andere manier om ouderen uit het verpleeghuis te houden is het verzorgingshuis de mogelijkheid bieden om chronische patiënten te huisvesten en de nodige zorg te verschaffen. Hoewel het verzorgingshuis strikt genomen geen tweedelijns gezondheidszorgvoorziening is, is het wel een intramurale voorziening. Daarom wordt deze vorm van substitutie hier opgenomen. Remmen (1985) onderzocht de gezondheidstoestand van verpleeghuispatiënten die langer dan een jaar opgenomen waren op een somatische afdeling van een verpleeghuis en vergeleek deze met die van verzorgingshuisbewoners. Hij stelde dat het merendeel van deze verpleeghuisbewoners geen baat meer had bij de specifieke deskundigheid van het verpleeghuils. Verder bleken hun symptomen en beperkingen niet te verschillen van die van verzorgingshuisbewoners, al kwamen bij hen wel meer symptomen en beperkingen voor. Op grond van deze bevindingen gaf Remmen de aanbeveling dat deze patiënten beter in het verzorgingshuis, een veel goedkopere voorziening, opgenomen konden worden. Dit zou voor deze patiënten het voordeel hebben van meer privacy, een eigen kamer en meubilair en een veel huiselijker klimaat. Bij deze op zich zinnige aanbeveling van Femmen dienen de volgende kanttekeningen geplaatst te worden. Het huidige verzorgingshuis kampt nu al met een tekort aan personeel dat deskundig is in verpleegtechmische handellingen. Pogingen om meer ziekenverzorgenden in dienst te nemen lopen vast op het feit dat het verpleeghuis een aanzienlijk hoger salaris kan bieden. Ook is voor zwaar hulpbehoevende patiënten de architectuur van een verzorgingshuis niet optimaal. Veelal kan bijvoorbeeld een ziekenhuisbed niet door de deur van een verzorgingshuis; ook zijn de loopafstanden voor het personeel er beduidend langer en is de mogelijkheid tot toezicht minder. Verder zal voor de huidige bewoners van het verzorgingshuis het woonklimaat afnemen doordat het verzorgingshuis toch 'verpleeghuisaspecten” krijgt. Tenslotte dient men te beseffen dat door deze verschuiving ana- 
loog aan die van ziekenhuis naar verpleeghuis, de verzorgingsprijs in beide woorzieningen zal stijgen, waardoor de berekende besparingen kunnen tegenvallen.

Door het tekort aan plaatsen op p.g. afdelingen van verpleeghuizen zien verzorgingshuizen zich overigens al meer en meer geconfronteerd met bewoners met gedragsstoornissen. Om deze problematiek het hoofd te kunnen bieden zijn er inmididels in verzorgingshuizen verschillende vormen van dagopvang en groepsverzorging ontstaan die tot doel hebben het gedrag van deze bewoners te structureren en tevens de overlast voor overige bewoners en personeel te verminderen. In hoeverre deze, min of meer uit nood geboren, vormen van zorg inderdaad in staat zijn verpleeghuisopname wit te stellen dient nog onderzocht te worden.

\section{Substitutie van de tweede naar de eerste lijn}

Men streeft ernaar de zorgverlening zoveel mogelijk in de eerste lijn te laten plaatsvinden. Steeds weer wordt gehamerd op een versterking van de eerste lijn - hetgeen met name personeelsuitbreiding en flexibele zorgverlening betekent - waardoor de verschuiving van tweede naar eerste lijn te realiseren zou zijn. Inmiddels moet een Kruisorganisatie om erkend te worden 24 uur bereikbaar zijn. Ook binnen de gezinszorg wordt de bedriffstijd steeds groter; van avond- en weekendzorg kan meer en meer gebruik gemaakt worden. Verder wil men meer aangepaste woningen voor ouderen gaan bouwen, waardoor zij langer zelfstandig zouden kunnen blijwen wonen. De realisering daarvan en van de personeelsuitbreiding gaat echter langzaam. Een getalsmatig voorbeeld van zo"m substitutieplan is in schema 2 weergegieven. Het is overgenomen uit het SCP-cahier "Samenhangen in de zorg voor ouderen" uit 1983. Het leek or destijds op dat gigantische besparingen mogelijk waren. Inmiddels blijkt dat de zorgverlening aan zwaar verplegingsbehoeftige patiënten door wijkwerpleegkundigen een enorme taakverzwaring met zich meebrengt. Steeds meer tijd van wijkverpleegkundigen blijkt hierin geïnvesteerd te worden, waardoor men steeds minder aan preventieve taken toekomt. In hoeverre men bezig is het paard achter de wagen te spannen kan nu nog niet vastgesteld worden. Maar mocht aangetoond worden dat wijkverpleegkundigen door middel van preventie institutionalisering kunnen voorkomen of uitstellen, zullen prioriteiten binnen het kruiswerk wellicht anders gesteld worden. Alleen met een substantiële uitbreiding van menskracht zal dan ook de curaw tieve, chronische zorg thuis uitgevoerd kunnen worden. De gezinsverzorging kampt met vergelijkbare problemen. Steeds meer wordt een beroep op hen gedaan om niet alleen huishoudelijke maar ook lichamelijk-hygiënische zorg op zich te nemen. Daar komt nog bij dat bij ouderen, die lichamelijke zorg nodig hebben, ook veel geestelijke problematiek voorkomt. Ook hier geldt dat dit werk alleen naar behoren uitgevoerd kan worden als er voldoende en goed opgeleid personeel beschikbaar is. In diverse beleidsnota's wordt erkend dat voor hulpbehoevende ouderen de zorg, die in de eerste lijn verleend wordt, allén miet voldoende is. Van de 'zorgzame samenleving" wordt dan ook steeds meer mantelzorg* verwacht. Uit eigen onderzoek weten wij dat er nu al veel mantelzorg verricht wordt. Door middel van een postenquête onder zelfstandig wonende ouderen werden het aantal beperkingen in huishoudelijke activiteiten (HHA-score) en het gebruilk van professionele zorg geinventariseerd. Daaruit bleek dat het percentage dat mantelzorg ontving varieerde van $67 \%$ voor de niet of nauwellijks hulpbehoevenden tot $85 \%$ voor ouderen met 4 of meer huishoudelijke beperkingen (zie figuur 2). In deze gecompliceerde zorgsituaties, waarbij men vaak

* De termen mantelzorg en informele zorg worden in dit hoofdstuk door elkaar gebruikt. 


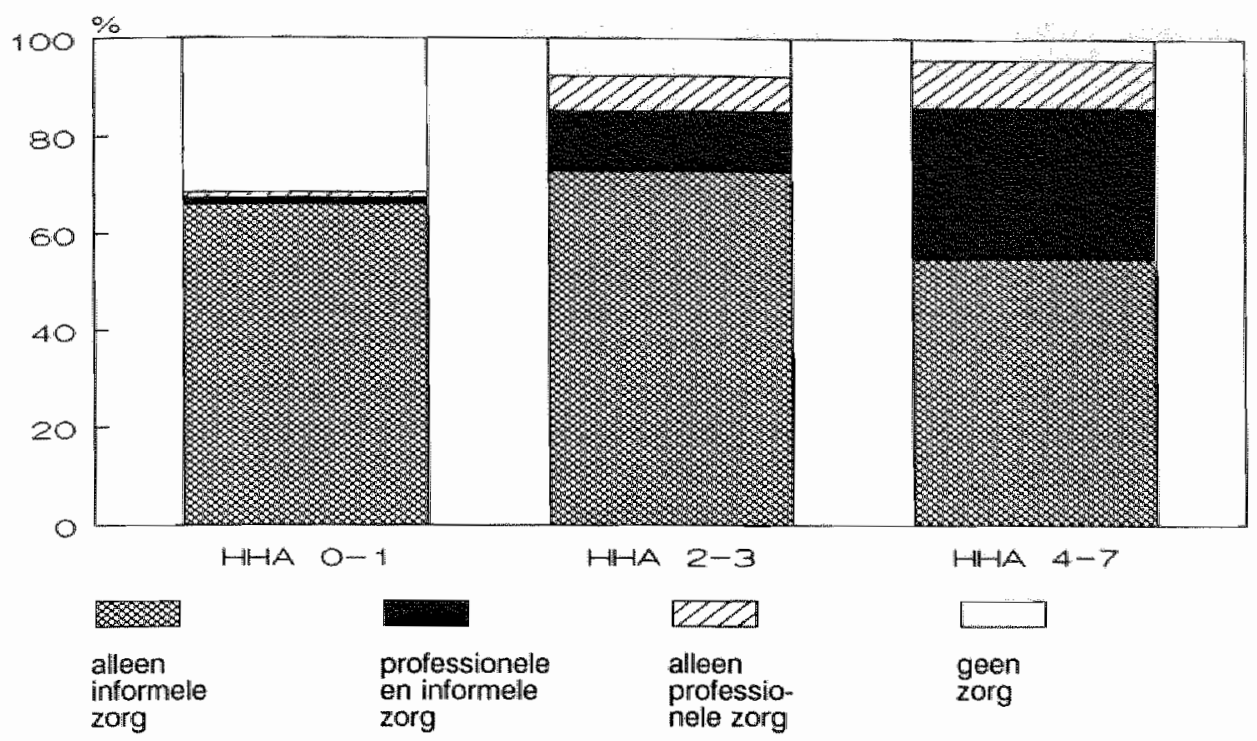

Figuur 2. Het gebruik wan informele en professionele zorg door thuiswonende ouderen in Maastricht ${ }^{3}$ Bron: Frederiks 1990

ook hulp bij de ADL nodig theeft, wordt professionele zorg bijna altijd door mantelzorg aangevuld.

Wij leiden hieruit af dat bij zwaar hulpbehoevende ouderen er weinig ruimte bestaat voor substitutie. Beide vormen van zorg lijken noodzakelijk te zijn om zich in de thuissituatie te handhaven. Er is bij deze ouderen meer sprake van elkaar aanvullen dan van elkaar vervangen. Het streven professionele zorg te vervangen door mantelzorg wordt dus beperkt doordat er een grens bestaat tot waar substitutie mogelijk is. Maar ook maatschappelijke ontwikkelingen frustreren dit streven. De feiten:

- dat ouderen steeds minder kinderen hebben;

- dat deze kinderen vaker dan vroeger ver van de ouders wonen;

- dat door het steeds ouder worden van de bevolking de verzorgende kinderen zelf steeds ouder worden.

maken dat er minder mantelzorg beschikbaar is.

Uit ons onderzoek kwam bovendien naar voren dat er door kinderen welliswaar veel huishoudelijke ondersteuning gegeven wordt, maar veel minder lichamelijk-hygiënische verzorging: lang niet elke relatie leent zich dus voor dergelijk intieme zorg.

Momenteel wordt het leeuwendeel van de mantelzorg verstrekt door vrouwen, meestal (schoon)dochters. Er is misschien nog enige uitbreiding van het mantelzorg-potentieel te realiseren door een mentaliteitsombuiging waarbij ook voor mannen deze vorm van zorgverlening meer vanzelfsprekend wordt. Uiteindelijk neemt het percentage nietwerkende mannen boven de vijttig jaar steeds meer toe en hebben vrouwen vaker dan vroeger naast het huishouden een betaalde (part-time)baan (zie figuur 3).

\section{Grensvervaging tussen de eerste en tweede lijn}

Men probeert het onderscheid tussen eerste en tweede lijn te laten vervagen. De Structuurnota Gezondheidszorg (1974) waarin het begrip echelonnering in Nederland geïntroduceerd werd, heeft de ordening en onderlinge verhouding van voorzieningen 
zeker bevorderd. Een te dogmatisch vasthouden aan deze echelonnering zou echter in de hand kunnen werken dat patienten die maar gedeeltelijk tweedelinszorg nodig hebben, hier toch volledig gebruik van maken. Vandaar het streven om de tweede lijn als het ware handreikingen te laten doen aan de eerste lijn, die hierdoor langer in stat is de zorg op zich te nemen. De onwikkeling van de dagbehandeling in ver pleeghuizen is hier al een voorbeeld van. Het beleid met betrekking tot het aanbieden van zorg door instellingen aan ouderen die daar niet verblijven, wordt flankerend beleid genoemd. Ten aanzien van verpleeghuizen wordt voor deze zorg ook wel het begrip "verpleeghuiszorg buiten de muren" gebruikt. In 1989 werd voor de "verpleeghuiszorg buiten de muren" voor het eerst extra geld beschikbaar gesteld. De voortdurende en toenemende capaciteitsproblemen waren hiervoor de aanleiding.

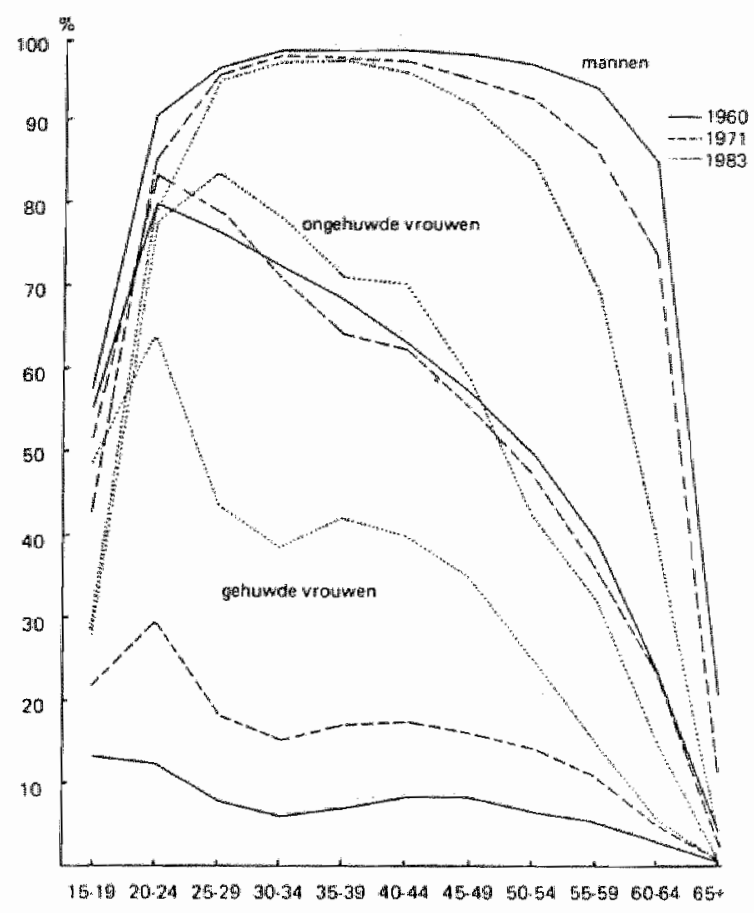

Figuur 3. Deelnemingspercentages aan de beroepsbevolking naar leeftij, geslacht en (voor vrouwen) burgerlijke staat (beroepsbevolking in personen, als percentage van de betreffen. de bevolkingsgroep)

Bron: Ministerie van Sociale Zaken en Werkgelegenheid 1984

Naast uitbreiding van de dagbehandeling hebben de verpleeghuizen verschillende opties om deze zorg vorm te geven. Eén mogelijkheid is dat huisartsen voor patiënten met gecompliceerde geriatrische problematiek verpleeghuisartsen kunnen raadplegen. Deze kan dan in de thuissituatie vaststellen of er een zorgtekort is, en zo ja, met welke hulp (middeien, medicatie, menskracht) zo'n patiënt nog in de thuissituatie geholpen kan worden. Voor verzorgingshuizen bestaat ook de mogelijkheid om verpleeghuisartsen te consulteren. Het gaat in dat geval niet om directe patiëntenzorg - daarvoor is immers de eigen huisarts van verzorgingshuisbewoners verantwoordellijk - maar meer om beleidsadvisering. Vragen als: welke bewoners komen in 
aanmerking voor groepsverzorging, bil welk gedrag dient een werpleeghuisopmame overwogen te worden en hoe dient het personeel om le gaan met gedragsgestoorde bewoners, kunnen dan aan de orde komen. Ook wordt aan personeel van verzor. gingshuizen de mogelikheid geboden om door middel van een stage in thet verpleeghuis verpleegkundige technieken aan te leren die voor de verzorging van de steeds meer zorgbehoevende verzorgingshuisbewoners van belang zijn. Daarmee is overigens de kwestie van de bevoegdheid om deze technieken toe te passen niet opgelostl Een laatste optie is dat het verpleeghuis in samenwerking met verzorgingshuizen een zogenaamde meerzorgafdeling gaat beheren. Bij zo'n meerzorgafdeling wordt een verpleeghuiskundige 'kop' gezet op de al aanwezig verpleegafdeling in een verzorgingshuis (Ministerie van WVC 1989). Deze optie lijkt veel op een verpleeghuisvorm die in de Nota 2000 bepleit wordt ${ }_{n}$ namelijk die met dependances. Kleinschalige instituten (zo'n 30 plaatsen), die in de wijk gelegen zijn ofwel bij een verzorgingshuis gesitueerd zijn, zouden de bereikbaarheid van een verpleeghuis voor mantelzorg en eerstelins werkers vergroten. Slechts voor specialistische zorg zou de inzet van verpleeghuispersoneel nodig zijn (Ministerie van WV 1986). Ondermeer omdat de 24-uurs beschikbaarheid van personeel hievoor een vereiste is en de kosten van een zelfstandig kleinschalig instituut relatief groot zijn, lijkt dependancevorming bij verzorgingshuizen het meest haalbaar. In hoeverre de dependancevorming achterhaald wordt door de ontwikkeling van de genoemde meerzorgafdelingen zal in de komende jaren bliken.

\section{Zorg op maat}

Met zorg op maat wordt het streven aangeduid om verleende zorg af te stemmen op individuele behoeften van zorggebruikers. Hiervoor is een grote mate van flexibiliteit vereist. In plaats van een standaardpakket zorg wordt mu individueel bezien waar tekorten in zelf- en mantelzorg optreden, en hoe en waar deze tekorten het beste door professionele zorgverlening kunnen worden aangevuld. Het is denkbaar dat. verpleeghuiszorg in de toekomst hierdoor vaker in de eigen woning of het verzorgingshuis verstrekt wordt. Instellingen zullen hierbij efficiënt te werk moeten gaam. In het Plan Dekker (1987) zullen ziektekostenverzekeraars contracten afsluiten met instellingen die gunstige prijs/kwaliteit verhoudingen aanbieden. In de gezondheidszorg zullen dan marktmechanismen als concurrentie en vraag-en aanbod hun intrede doen. Het is in dit stadium nog te vroeg om dit verder wit te werken, maar het is goed mogelijk dat deze laatste ontwikkeling het meest richtinggevend zal zijn voor het verpleeghuis in de toekomst. 


\section{Sichema 2. SUBSTITUTIEPLAN VOOR VOORZIENINGEN VOOR OUDEAEN}

\section{UITGANGSPUNTEN:}

beddenreductie in ziekenhuizen tot de vastgestelde norm van 10,25 bed per 1.000 bejaarden is bereikt:

- iedere aldus prijsgegeven verpleegdag wraagt een contact met de wijkverpleging;

- terugbrengen van de capaciteit van bejaardenoorden tot 116.000 ;

- 27000 bejaarden ontvangen in plaats daarvan 400 uur gezinsverzorging;

- 13.500 kriigen tewens cen bejaardenwoning toegewezen;

- 5.000 van hen ontvangen dienstveriening in het kader wan de wijkfunctie van het bejaarden. oord:

- de capaciteit van verpleeghuizen wordt met 9.000 bedden verminderd:

9.000 bejaarden ontvangen dagbehandeling;

- 4.500 van hen verblijuen in een bejaardenoord:

- de andere 4.500 verblijven in een eigen woning:

- de eigen woning zal een bejaardenwoning moeten zijn waarvoor ook individuele huursubsidie wordt verstrekt;

- tewens ontvangen deze 4.500400 uur gezinswerzorging per jaar;

- tevens hegft leder van deze 4.500100 contacten met de wijkverpleging per jaar.

\section{GEVOLGEN VOOR DE KOSTEN EN HET PERSONEEL:}

KOSTEN van het gebruik wan acht zorgvoorzieningen in 1986, voorzover deze kosten toe te rekenen zijn aam bejaarden en ten laste komen wan de collectieve uitgaven, VOOR EN NA SUBSTITUTIE (extrapolatie).

\begin{tabular}{|c|c|c|c|c|}
\hline & $\begin{array}{l}\text { Kosten woor } \\
\text { substitutie } \\
\text { (minj }\end{array}$ & $\begin{array}{l}\text { Kosten na } \\
\text { substitutie } \\
\text { (min) }\end{array}$ & $\begin{array}{l}\text { Besparing } \\
\text { door } \\
\text { substitutie }\end{array}$ & $\begin{array}{l}\text { Kosten } \\
1980 \\
\text { (m/n) } \\
\end{array}$ \\
\hline Bejaardenoorden & 2792 & 2353 & +439 & 1720 \\
\hline Verpleeghuizen & 2952 & 2340 & 612 & 2228 \\
\hline Dagbehandeling & - & 165 & 165 & - \\
\hline Ziekenhuizen & 3830 & 3192 & 638 & 2228 \\
\hline Wilkverpleging & 222 & 278 & 56 & 192 \\
\hline Gezinswerzorging & 650 & 872 & 222 & 572 \\
\hline Bejaardenwoningen & 551 & 592 & 41 & 306 \\
\hline Wilkfunctie & + & -20 & 20 & \\
\hline Totaal & 10997 & 9812 & +1185 & 7246 \\
\hline
\end{tabular}

PERSONEEL in acht zorgvoorzieningen in 1986, voorzover dit ten dienste staat van bejaarden, VOOR EN NA SUBSTITUTIE (extrapolatie).

\begin{tabular}{lcccc} 
& $\begin{array}{l}\text { Personeel woor } \\
\text { substitutie }\end{array}$ & $\begin{array}{c}\text { Personeel na } \\
\text { substitutie }\end{array}$ & Verschil & $\begin{array}{c}\text { Personeel } \\
1980\end{array}$ \\
\hline Bejaardenoorden & 49755 & 41934 & -7821 & 47947 \\
Verpleeghuizen & 53591 & 42484 & -11107 & 41868 \\
Dagbehandeling & - & 3978 & +3978 & - \\
Ziekenhuizen & 48175 & 40126 & -8049 & 42336 \\
Wijkverpleging & 3279 & 4117 & +838 & 2574 \\
Gezinswerzorging & 30919 & 41455 & +10536 & 22304 \\
Bejaardenwoningen & - & 355 & +355 & - \\
Wijkfunctie & - & 174429 & -11290 & 157029 \\
\hline Totaal & 185719 & & & - \\
\end{tabular}




\section{Literatuur}

Almekinders M. Historische ontwikkeling van het verpleeghuiswezen. In: De identiteit van het verpleeghuis. Lochem, De Tijdstroom 1980.

Centrale Raad voor de Volksgezondheid. Advies verpleeghuizen I (1966), II (1971). III(1972). Den Haag, Staatsuitgeverij.

Centrale Raad voor de Volksgezondheid. Interimadvies inzake het functioneren van verpleeghuizen. Den Haag, Staatsuitgeverij 1982.

Centrale Raad voor de Volkgsgezondheid. Tweede Advies nomenclatuur van inrichtingen voor gezondheidszorg. Den Haag. Staatsuitgeverij 1972.

Claessens WLM. Multidisciplinaire observatie van vermeend psychogeriatrische patiënten. Lisse, Swets en Zeitlinger 1984.

College voor Ziekenhuisvoorzieningen.. Beoordelingsmaatstaven voor bouwplannen van verpleeghuizen. Utrecht 1981.

Commissie Structuur en Financiering Gezondheidszorg. Bereidheid tot Verandering ('Plan Dekker"). Den Haag, DOP 1987.

Diesfeldt HFA. De BOP tien jaar. Gerontologie 1981; 12: 139-147.

Fleischeuer J, Kooy $\mathrm{C}$ van der. Realiteitsoriëntatie en de werkelijkkeid van de verpleeghuisbewoner. Tijdschrift voor Gerontologie en Geriatrie 1989; 20: 197-201.

Frederiks CMA. Zorgbehoefte van en zorgverlening aan ouderen. Proefschrift Rijksuniversiteit Limburg, Maastricht 1990.

Hattinga Verschure JCM. Kritisch onderzoek naar de zorgverlening rond de verpleeghuispatiënt. In: De identiteit van het verpleeghuis. Lochem, De Tijidstroom 1980.

Have H ten. Het verpleeghuis; veld van onderzoek. Deventer, Van Loghem Slaterus 1979.

Huijsman R. Kosten en gebruik van voorzieningen door ouderen in Nederland. In: Huijsman R. Rutten FFH (red). Economie van de Ouderenzorg. Assen/Maastricht, Van Gorcum 1989.

Kam P van der, Mol F, Wimmers MFHG. Beoordelingsschaal voor Qudere Patiënten. Deventer, Van Loghum Slaterus 1971.

Katz S, Ford AB, Moskowitz RW, Jackson BA, Jaffe MW. Studies of illness in the aged. The Index of ADL: A standardized measure of biological and psycho-social function. JAMA 1963; 185: 914-919.

Leering C. Gestoord menselijk functioneren: een onderzoek naar de structuur van de algemeen dagelijkse levensverrichtingen (ADL) bij patiënten in verpleegtehuizen.

Nijmegen, Dekker \& Van de Vegt 1968. 
Melchior T. De BOP en de GIP in de psychogeriatrie. Doctoraalscriptie Gezondheidswetenschappen, Maastricht 1990.

Michels JJM. Verpleeghuisgeneeskunde. Inaugurale rede Katholieke Universiteit Nijmegen. Nijmegen, Dekker en van de Vegt 1980.

Ministerie van Sociale Zaken en Werkgelegenheid. Rapportage arbeidsmarkt 1984. Den Haag, Directie Algemene Beleidsplanning 1984.

Ministerie van Volksgezondheid en Milieuhygiëne. Structuurnota Gezondheidszorg. Den Haag, Staatsuitgeverij 1974.

Ministerie van WVC. Financieel Overzicht Zorg 1989. Den Haag, Staatsuitgeverif 1988.

Ministerie van WVC. Financieel Overzicht Zorg 1990. Den Haag, Staatsuitgeverij 1989.

Ministerie van WVC. Nota 2000. Den Haag, Staatsuitgeverij 1986.

Ministerie van WVC. Planningsnorm verpleeghuizen. Rijswijk 1989.

Ministerie van WVC. Richtilinen ex art 3 WZV. Rijswijk 1986.

Nationale Ziekenhuisraad. Discussienata taak en functie verpleeghuizen. Utrecht 1981.

Nies HLGR. Dagbehandeling? Een tussentijdse belans van dagbehandeling in verpleeghuizen. Tijdschrift voor Gerontologie en Geriatrie 1986; 17: 25-32.

Remmen JWM. Bejaardenoordbewoners of verpleeghuispatiënten? Hoogezand, Stubeg 1985.

Schreuder, J.Th.R. De geriatrische patiënt. Nederlands Tijdschrift voor Geneeskunde 1966; 110: 1825-1828.

SIG. Sivis Jaarboek 1987. Utrecht, SIG 1988.

SIG. Jaarboek verpleeghuizen 1988. Utrecht, SIG 1989.

Spaan JM. Verpleeghuizen in cijfers. Utrecht, NZI 1989.

Timmermans J. Samenhangen in de zorg voor ouderen. Rijswijk, Sociaal en Cultureel Planbureau 1983.

Verstraten PFJ, Eekelen CWJM van. Handleiding voor de GIP, Gedragsobservatieschaal voor de Intramurale Psychogeriatrie. Deventer, Van Loghum Slaterus 1987.

Wimmers MFHG. Verpleeghuizen en hun bewoners; een methodische benadering van de bewoners, beoordeeld op medische en gedragsaspecten. Proefschrift Katholieke Universiteit Nijmegen 1976. 


\section{Noten}

1 De gepresenteerde percentages bij de schema"s 2a-2d zijn exclusief de 0-54 jarigen; $\pm 4 \%$ van de somatische en $1 \%$ van de psychogeriatrische patiënten zijn bij opname jonger dan 55 jaar.

2 Sinds 1988 hanteert de SIG een andere indeling van het doel van de zorgverlening. Wij hebben 'gangbare verpleeghuiszorg met paramedische zorg' beschouwd als reactivering; 'gangbare verpleeghuiszorg met stervensbegeleiding' als terminale zorg en de overige categoriën ('gangbare verpleeghuiszorg', 'gangbare verpleeghuiszorg met gerichte observatie of met bedverpleging, medische zorg of psychosociale hulp') als chronische zorg.

$3 \mathrm{HHA}=$ het aantal van 7 huishoudelijke activiteiten die men niet zelf kan verrichten; deze activiteiten zijn: een broodmaaltijd klaarmaken, het bed opmaken, stof afnemen en afwasen, dweilen en ramen lappen, de dagelijkse boodschappen doen, de was doen en koken.

Professionele zorg = minstens één maal per week hulp ontvangen van de gezinszorg en/of de wijkverpleging.

Informele zorg = minstens één maal per week hulp ontvangen van de partner, familie, buren, kennissen of particuliere hulp, dus van niet-professionele zorgverleners. 



\section{HOOFDSTUK 3}

\section{VERPLEEGHUISOPNAME;}

EEN ONDERZOEK BIJ OP TE NEMEN OUDEREN*

Margreet JM te Wierik, Carla MA Frederiks, APh Visser, F Sturmans 


\section{Samenvatting}

In dit hoofdstuk worden de hulpbehoefte, het sociale netwerk, de woonsituatie, het gebruik van zorg en de hoofddiagnose beschreven van 157 ouderen die werden opgenomen in een verpleeghuis. Nagegaan is of deze kenmerken verschillen naar aard van verblijf vóór de opname (eigen omgeving versus zjekenhuis) en het doel van de verpleeghuisopname (reactivering versus permanente ondersteuning). Tevens wordt ingegaan op de vraag in hoeverre bij deze ouderen substitutie mogelijk is. Binnen de groep op te nemen verpleeghuispatiënten zijn vrij duidelijk subgroepen te onderscheiden, alhoewel de hulpbehoefte, het sociale netwerk, met uitzondering van het op bezoek gaan, en de achtergrondkenmerken niet bleken te verschillen naar aard van verbliff vóór opname en doel van de opname. Het onderscheid ligt vooral in de aard van de aandoeningen (psychogeriatrisch versus somatisch en chronisch versus min of meer acuut), hetgeen niet alleen uit de hoofddiagnose zelf, maar ook uit verschillen in woonsituatie, het op bezoek gaan bij anderen en het gebruik van zorg voorafgaand aan de opname naar voren komt. Gegeven het voorgestelde substitutiebelleid zou ruim een kwart van deze op te nemen patiënten in aanmerking komen voor substitutie. De zware hulpbehoefte en de omvang van de informele en professionele zorg voorafgaand aan de opname, naast een tekort aan alternatieve woonvormen, doen echter vermoeden dat de substitutiemogelijkheden in werkelijkheid veel beperkter zijn.

\section{Summary}

\section{Nursing home admittance; a study among elderly applicants}

This chapter describes the care needs, the social network, the housing conditions, the utilization of care and the diagnoses of 157 elderly applicants to nursing homes in Maastricht. The study was carried out during the period of February 1987 to July 1988. It was investigated whether these characteristics differed in relation to the goal of the admission (rehabilitation versus continuous support) and in relation to prior living arrangements (home versus hospital). In addition, the question to what extent substitution of care is possible is discussed. Within the group of nursing home applicants, a fairly clear distinction could be made between a number of subgroups, although care needs, sacial network (with the exception of the number of visits paid), and demographic characteristics showed no differences in relation to admission goals and prior living arrangements. The distinction was based particularly on the nature of the disorders (psychogeriatric versus somatic and chronic versus more or less acute), which was reflected not only in the main diagnosis itself, but also in differences in housing conditions, numbers of visits paid to others, and utilization of care prior to admission. Under the proposed policies for substitution, about a quarter of the applicants would be eligible for substitution. However, the major care needs, and the levels of formal and informal care prior to admission, as well as the shortage of alternative services, would seem to indicate that the actual possibilities for substitution are more limited. 


\section{Inleiding}

Het huidige ouderenbeleid is erop gericht de zelfstandigheid van ouderen zolang mogelik te behouden. Aanleidingen woor dit beleid zijn financieel-economische ontwikkelingen, zorginhoudelijke overwegingen en de dubbele vergrijzing. Bij de verwezenlijking ervan wordt aan substitutie van zorg een grote rol toegedicht (Ministerie van WN 1986 en 1990). Een aanwijzing dat substitutie tot de mogelijkheden behoort is dat, hoewel een deel van de thuiswonende ouderen een hulpbehoefte heeft die past bij opname in een verzargingshuis, de opname veelal niet aangevraagd wordt (Bisscheroux en Frederiks 1986; De Amsterdamse bejaarden 1977). Een andere aanwijzing is dat in ons land, in vergelijking met andere landen, een hoog percentage ouderen geinstitutionaliseerd is. Omdat het niet aannemelijk is dat ouderen hier hulpbehoevender zijn, wordt elders blijkbaar op andiere wijze in de hulpbehoefte voorzien. Naast de hulpbehoefte spelen dus ook andere factoren een rol bij gebruik van voorzieningen door ouderen. Inzicht in die factoren kan bijdragen aan de ontwikkeling van een zorgvuldig substitutiebeleid. In dit kader is in Maastricht een onderzoek uitgevoerd naar het verschillend gebruik van voorzieningen door ouderen met een gelijke mate wan invaliditeit. In dit artikel worden gegevens gepresenteerd over ouderen die worden opgenomen in een verpleeghuis.

Het verpleeghuis is de laatste schakel in het voorzieningenpakket voor ouderen. De patiëntenpopulatie is heterogeen. Naar doel van de opname kunnen terminale patiënten, reactiveringspatiënten en chronische somatische en psychogeriatrische patiënten worden onderscheiden. Het is aannemelijk dat bij verschillende doelen andere factoren de beslissing tot opname beinwloeden. Bij opname van terminale en reactiveringspatiënten kunnen de gezondheidstoestand en de prognose daarvan een belangrijke rol spelen; bij opname van chronische patiënten kunnen het sociale netwerk of de woonsituatie belangrijke factoren zijn. Tevens zullen er verschillen zijn naar aard van verblijf vóór opname: bi] patiënten die vanuit de eigen woonomgeving worden opgenomen kunnen de informele zorg door het sociale netwerk en de ontvangen professionale zorg van belang zijn, terwijl bij patiënten afkomstig uit het ziekenhuis deze kenmerken niet of minder meespelen omdat zij voorafgaand aan de ziekenhuisopname lang niet altijd hulpbehoevend waren. In dit hoofdstuk worden de hulpbehoefte, het sociale netwerk, de woonsituatie, het gebruik van zorg voorafgaand aan de opname en de hoofdidiagnose van de op te nemen verpleeghuispatiénten beschreven. Om inzicht te krijgen in de achtergronden van de verpleeghuisopname wordt nagegaan of deze kenmerken verschillen naar aard van verblijf vóor de opname en of deze kenmerken samenhangen met het doel van de opname. In de discussie worden de bevindingen besproken en wordt ingegaan op de vraag in hoeverre bij deze ouderen substitutie van zorg mogelijk is.

\section{Opzet en uitvoering van het onderzoek}

Het onderzoek bij 157 op te nemen verpleeghuispatiënten $(55+)$ vond plaats in Maastricht gedurende de periode februari 1987 tot en met juli 1988 ." Terminale

\footnotetext{
* Aan het begin van de onderzoeksperiode beschikte Maastricht over ॥ gecombineerd verpleeghuis met 396 bedden. Er was een tekort aan zowel somatische als psychogeriatrische bedden. Somatische patienten werden daarom soms tijdelijk opgenomen in verpleeghuizen in amliggende steden. Voor psychogeriatrische patiënten waren de uitwijkmogelijkheden veel beperkter. De opening van een nieuw gecombineerd verpleeghuis met een capaciteit van 120 bedden in oktober 1987 bracht hierin werandering.
} 
patiënten werden uitgesioten van het onderzoek, o.a. omdat deelname te belastend zou zijn. De op te nemen verpleeghuispatiënten of een centrale verzorger werden omwille van de privacy eerst via de maatschappelijk werkenden van de verpleeghuizen tijdens het huisbezoek benaderd voor medewerking aan het onderzoek. (Ten tijde van het onderzoek was er nog geen sprake van de gecombineerde indicatiestelling voor verpleeg- en verzorgingshuizen; zoals die sinds januari 1989 van kracht is.) In totaal werd circa de helft van de in aanmerking komende groep op te nemen verpleeghuispatiënten voor het onderzoek aangemeld; van de aangemelde groep heeft $80 \%$ aan het onderzoek deelgenomen. De maatschappelijk werkenden gaven aan dat zij het vragen om medewerking moeilijk en conflicterend met het eigenlijke doel van het huilsbezoek vonden. De belangrijkste redenen voor de $20 \%$ non-respons waren dat de centrale verzorgers de situatie rondom de opname te moeilijk vonden of dat hun eigen gezondheid een interview niet toeliet. Om deze redenen is het aannemelijk dat een ondervertegenwoordiging is opgetreden van patiënten bij wie de situatie voorafgaand aan de verpleeghuisopname moeilijk en complex was. Uit vergelijking met landelijke gegevens komt niettemin naar voren dat de deelnemers aan het onderzoek bij opname minstens zo hulpbehoevend waren als verpleeghuispatiënten in het algemeen: het landelijk gemiddelde van de SIVIS-hulpindex bij opname bedroeg in 1987 7.13 , voor de patienten in het onderzoek was dit 7.98 (SIG 1988).

De gegevens zijn verzameld middels mondelinge interviews met de op te nemen verpleeghuispatiënten zelf of een tweede respondent, in het algemeen een centrale verzorger. Met een gestructureerde vragenlijst werd informatie verkregen over de mate van invaliditeit, het gebruik van professionele en informele zorg, de woonsituatie en het sociale netwerk. De vragenlijst is in een pilotstudie bij hulpbehoevende thuiswonende ouderen en verzorgingshuisbewoners uitgetest en bruikbaar bevonden (Bisscheroux en Frederiks 1986). De interviews werden in principe voorafgaand aan de opname door getrainde interviewers bij de respondenten thuis afgenomen. In die gevallen waarin de tijd tussen de aanvraag en opname daarvoor te kort was, vond het interview zo kort mogelijk na de opname plaats. In tabel 1 zijn de onderzochte begrippen met de operationalisatie ervan weergegeven; waar relevant zijn tevens de schaaltechnische gegevens vermeld. De vragen hadden betrekking op de situatie voorafgaand aan de verpleeghuisopname. In die gevallen waarin aan de verpleeghuisopname een opname in ziekenhuis of andere gezondheidszorginstelling voorafging, zijn de vragen omtrent het gebruik van professionele zorg, de woonsituatie en het sociale netwerk gesteld over de periode vór die opname. De medische gegevens zoals het doel van de opname en de hoofddiagnose zijn kort na de opname schriftelijk verkregen van de behandelend verpleeghuisarts. Daarbij werd gebruik gemaakt van de classificaties van het SIVIS-registratiesysteem (SIG 1984).

De gegevens zijn bivariaat geanalyseerd. Bij de beschrijving van de situatie van de op te nemen patienten voorafgaand aan de verpleeghuisopname is de sterkte van een aantal onderlinge verbanden bepaald met behulp van Kendall's tau gezien het meetniveau van de variabelen. De vraag of de geïnventariseerde kenmerken van de patiënten verschillen naar aard van verblijf vóór de apname en het doel van de opname is
getoetst met $\chi^{2}$-testen.

\section{Resultaten}

\section{Achtergrondkenmerken}

De verdeling van leeftijd naar geslacht van de groep op te nemen verpleeghuispatiënten is weergegeven in tabel 2. Driekwart van de patiënten was 75 jaar of ouder; de 
Tabel 1. De onderzoekswariabelen met hun operationalisiatie

\section{Achtergrondkenmerken Lewftijd \\ Geslucht: \\ Burgerijile stat}

Aard ven verbllañ woun de opneme

\section{Hulpbehoefte}

\section{Huishoudelinke} invaliditeit

\section{Lichameliake}

invaliditeit

\section{Woansituatie}

Type woning

Woondult

Sociaal netwerk

Samenstelling

huishouden

Kindertal

Bezorek

\section{Hat gobruik van zorg}

Protessionale zorg

Informele zorg bil hat hulshowden

Intarmale zorg bil d. AOL

Totalo informelie zorg

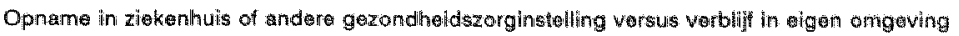
(incl. varzorgingsinuis)

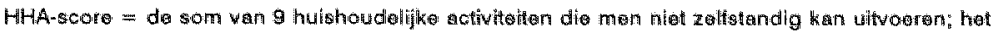

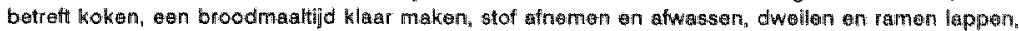

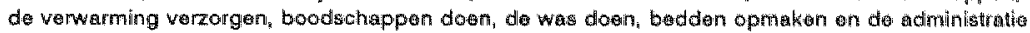
bijhouden; range: $0.9 ; 0.67$

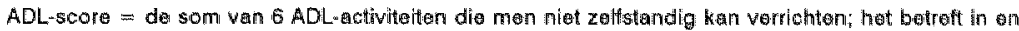

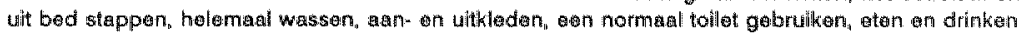

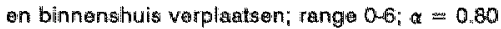

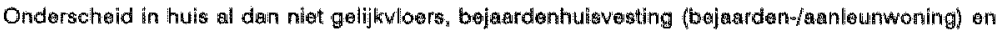
verzorgingshuis

Het alantal jaren dat men in da huidige woning woont

Al dan nief samenwwonen met partiner, kinderen of anderen

Aantal kinderen in bu buiten de woomplaats

Frequentie wam bezoelk wan kinderen per maend

Frequentie vam thet totale bezozth per meand

Frequentie wam op bezoak gaan per maand

Hulp van de gezinszerg endol ADL-onderstetuning door de wifkverpleging in de etgelopen 3 maandwer of verbliff in een varzorgingshuits

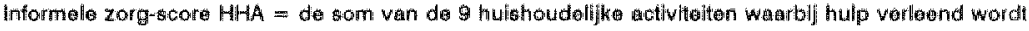

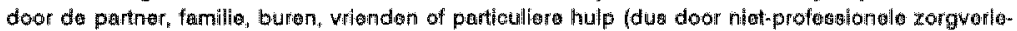
narsy; range: 0,$9 ;=0.69$

Informele zorg-score ADL = de som van de B ADLwetlivteiten wearbil informale zorig verleond word

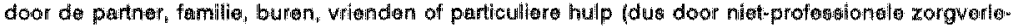
nersh: range: $0-6_{\mathrm{n}}^{\mathrm{n}} \alpha=0.87$

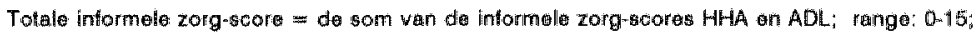
$a=0.93$

mediane leeftijd was 80 jaar. De mannen waren wat jonger dan de vrouwen. Mannen waren dan ook vaker (nog) gehuwd dan vrouwen ( $45 \%$ resp. $15 \%$ ) en minder vaak verweduwd $(37 \%$ resp. $66 \%)$.

\section{Aard van verblijf vóór de opname}

De helft van de op te nemen patiënten was afkomstig uit de eigen omgeving; de andere helft was afkomstig uit een ziekenhuis $(n=71)$ of een andere gezondheids- 
zorgvoorziening $(n=8$ ), veelal een ander verpleeghuis (deze groep van 79 patiënten wordt in het vervolg aangeduid als afkomstig uit een ziekenhuis).

Tabel 2. De onderzoekspopulatie naar leeftijd en gestacht (\%)

\section{Geslacht}

Leeftilid man urouw totaal

$\begin{array}{lrrr}55-65 & 4(8) & 4(4) & 8(5) \\ 65-74 & 14(29) & 19(17) & 33(21) \\ 75-84 & 19(39) & 54(50) & 73(47) \\ 85+ & 12(24) & 31(29) & 43(27)\end{array}$

\begin{tabular}{|c|c|c|}
\hline Totaal & $49(100)$ & $108(100)$ \\
\hline
\end{tabular}

\section{De hulpbehoefte}

De mate van hulpbehoevendheid wordt weergegeven door de HHA- en ADL- scores. Uit de verdeling van de HHA-scores (tabel 3) blikkt dat $92 \%$ van de patiënten volledig hulpbehoevend was ten aanzien van het huishouden (HHA-score 8-9). De ADL-score is minder scheef verdeeld, alhoewel ook hier geldt dat de hoogste scores het vaakst voorkwamen: 49\% had een ADL-score van 5-6 (tabel 3). Ouderen die vanuit een ziekenhuis opgenomen werden lijken hulpbehoevender te zijn dan ouderen die vanuit de eigen omgeving werden opgenomen; de verschillen zijn echter niet statistisch significant.

\section{De woonsituatie}

Driekwart van de patiënten die vanuit een ziekenhuis werden opgenomen woonde voordien in een normaal huis, veelal niet gelijkvloers (tabel 3). Patiënten die niet vanuit een ziekenhuis werden opgenomen woonden relatief vaak in een verzorgingshuis $(40 \%)$. Het aandeel van bejaardenhuisvesting was gering $(7 \%)$. Een ruime meerderheid $(72 \%)$ woonde al 6 jaar of langer in de huidige woning. Slechts $7 \%$ was het afgelopen jaar verhuisd, voornamelijk naar een verzorgingshuis.

\section{Sociaal netwerk}

Van de patiënten woonde $55 \%$ alleen; $23 \%$ woonde samen met hun partmer. De overige $22 \%$ woonde samen met kinderen of met anderen (12\% resp. $10 \%)$. Zoals de verschillen in burgerlijke staat al doen vermoeden bleken vrouwen vaker alleen te wonen dan mannen (62\% versus $41 \%)$. Ruim een kwart van de patienten ( $27 \%$ ) had geen kinderen; bij $8 \%$ woonden de kinderen niet in dezelfde woonplaats. De overige patiënten hadden éen of meer kinderen in de nabijheid wonen. Bijna de helft ontving dan ook veel bezoek van de kinderen; $30 \%$ gemiddeld zelfs dagelijks (tabel 4). 
Het totale bezoek was uiteraard geassocieerd met het bezoek van kinderen (Kendall's tau $=0.44)^{*}$; wel is uit tabel 4 af te leiden dat geen bezoek van kinderen tot op zekere hoogte gecompenseerd wordt door bezoek van anderen. In totaal ontving slechts $1 \%$ van de patiënten geen bezoek. Deze gegevens over het sociale netwerk verschillen niet naar herkomst" het op bezoek gaan daarentegen wel $\left(x^{2}\right.$ test). Ouderen die vanuit de eigen omgeving worden opgenomen, gaan vaak niet (meer) bij anderen op bezoek (72\%). Van degenen die in een ziekenhuis verblewen ging ruim de helft $(56 \%)$ voorafgaand aan de ziekenhuisopname wel op bezoek bil anderen.

Tabel 3. Enkele kenmerken van de op te nemen verpleeghuispatięnten naar aard van verblijf wớrl de opname (\%)

Aard van verblijf vóór de opname

$\begin{array}{lll}\text { Eigen omgeving } & \text { Ziekenhuis } & \text { Totaal } \\ (n=78) & (n=79) & (n=157)\end{array}$

HHA-score
0-3
4-7
8-9

ADL-score

$0-2$
$3-4$
$5-6$

Type woning ${ }^{c}$

Huis niet gelijkwloers

Huis gelijkvloers

Bejaarden-/aanleunwoning

Verzorgingshuis

Anders

Professionele hulp ${ }^{d}$

Geen professionele hulp 6 (8)

Wilk- of gezinszorg

Wiik-en gezinszorg

Verzorgingshuis:

Doel van de opname"

Permanente ondersteuning

Reactiveren

Anders
$9(12)$

$67(88)$

25 (32)

$21(27)$

$32(41)$

$29(37)$

$12(15)$

$4(5)$

$31(40)$

2(3)

$6(8)$
$25(32)$

$16(20)$

$31(40)$ $(n=79)$

$-$

$3(4)$

$74(96)$

$19(25)$

$13(17)$

$43(57)$

41 (52)

$18(23)$

$7(9)$

$13(16)$

$-$

$4.153)$

$18(23)$

$5(7)$

$13(17)$

$48(61)$
$20(26)$
$10(13)$
$36(46)$

35 (45)

7 (9)
$-$ 12( 8$)$ 141 (92)
a: $x^{2}=2.3 p>0.1$
d: $x^{2}=40.3 p<0.001$
$b: x^{2}=4.3 p>0.1$
$c: x^{2}=13.4 p<0.01$
e: $x^{2}=6.3 p<0.05$

47 (30)

$43(28)$

$21(14)$

$44(28)$

* Wanneer in de tekst een associatiemaat gepresenteerd wordt, is de overschrijdingskans altijd kleiner dan 0.05 . 
Tabei 4. Frequentie van bezoek van kinderen naar het totale bezoek per maand (\%)

\section{Totale Bezoek}

\begin{tabular}{lccccc}
$\begin{array}{l}\text { Bezoek van } \\
\text { kinderen }\end{array}$ & 0 & $1-16$ & $17-30$ & $31+$ & totaal \\
\cline { 3 - 6 } & 2 & 14 & 12 & 16 & $44(28)$ \\
1.16 & - & 20 & 8 & 8 & $36(23)$ \\
$17-30$ & - & - & 15 & 14 & $29(19)$ \\
$31+$ & - & - & - & 46 & $46(30)$
\end{tabular}

Totaal

$2(1)$

$34(22)$

35 (23)

$84(54)$

$157(100)$

Kendall's tau $=0.44 p<0.01$

\section{Gebruik van zorg}

Ouderen die vanuit de eigen omgeving werden opgenomen bleken over het algemeen gebruik te maken van professionele hulp; slechts $8 \%$ had geen professionele hulp (tabel 3). De ouderen, afkomstig uit het ziekenhuis, maakten voorafgaand aan de ziekenhuisopname veel minder gebruik van professionele zorg: ruim de helft van deze ouderen (53\%) had geen professionele zorg.

De ouderen die zelfstandig woonden, ontvingen naast professionele zorg ook vrij veel informele zorg. (De verzorgingshuisbewoners blijven hierbij buiten beschouwing aangezien de instelling de hulp verstrekt die nodig is bij het huishouden en de persoonlijke verzorging.) Ruim de helft (58\%) van deze zelfstandig wonende ouderen had veel informele zorg bij het huishouden (score 8-9); slechts $6 \%$ had weinig of geen informele zorg (score 0-2). Ook bij de ADL werd veel informele zorg geboden, zij het minder dan bij het huishouden. Bijna 40\% ontving veel informele zorg (score 5-6); $34 \% \mathrm{kreeg}$ weinig tot geen informele hulp bij de ADL (score 0-2). Zoals te verwachten was, bleek het gebruik van informele en professionele zorg samen te hangen (tabel 5). Bij weinig informele zorg bij het huishouden en de ADL (score 0-6) werd door allen gebruik gemaakt van wijk- en/of gezinszorg. Bij veel informele zorg (score 12+) maakte men vaker gebruik van één van de twee mogelijke vormen van professionele thuiszorg. Samenwonenden ontvingen meer informele zorg dan alleenwonenden (tabel 6). Om na te gaan wie de informele zorg verleende, zijn in tabel 6 naast de gemiddelde informele zorg-scores ook gemiddelde scores weergegeven zonder de zorg verleend door partners, inwonende kinderen of andere huisgenoten. Uit de verschillen is af te leiden dat bij samenwonenden het merendeel van de informele zorg bij het huishouden maar vooral ook bij de ADL verleend werd door huisgenoten.

\section{Het doel van de opname}

Bij ruim de helft van de patiënten $(54 \%)$ was het doel van de opname het permanent ondersteunen van een aantal levensfuncties; $35 \%$ werd opgenomen om gereactiveerd te worden (tabel 3). Bij ouderen afkomstig uit de eigen omgeving was het doel van de opname vaker permanente ondersteuning en minder vaak reactiveren in vergelijking $46 \%$ resp. $45 \%$ ). 
Tabel 5. Gebruik van informele en professionele thuiszorg door zelfstandig wonende ouderen

Gebruik professionele thuiszorg

Totalle informele zorg-score

$\begin{array}{ll}\text { Geen professio- } & \text { Wijk- of } \\ \text { nele zorg } & \text { gezinszorg }\end{array}$

Wijk-en

gezinszorg Totaal

\begin{tabular}{lrrrr}
\hline $0-6$ & - & 5 & 5 & 10 \\
$7-11$ & 3 & 9 & 7 & 19 \\
$12+$ & 3 & 11 & 4 & 18 \\
\hline Totaal & 6 & 25 & 16 & 47 \\
\hline
\end{tabular}

Kendall's tau $=-0.20 p<0.06$

Tabel 6. Gemiddelde informele-zorg scores bij zelfstandig wonende ouderen naar samenlevingsverband (standaard afwijking)

Gemiddelde informele-zorg scores

HHA

\begin{tabular}{llll}
\hline $\begin{array}{l}\text { met } \\
\text { inwonenden }\end{array}$ & $\begin{array}{l}\text { zonder } \\
\text { inwonenden }\end{array}$ & $\begin{array}{l}\text { met } \\
\text { inwonenden }\end{array}$ & $\begin{array}{l}\text { zonder } \\
\text { inwonenden }\end{array}$ \\
\hline nvt & $5,3(2,6)$ & nvt & $1,9(2,3)$ \\
$7,5(1,3)$ & $1,9(2,0)$ & $3,1(1,6)$ & $0,3(0,9)$ \\
\hline
\end{tabular}

$5,3(2,6)$
$A D L$ alleenwonenden $(n=14)$ nvt

samenwonenden $(n=33) \quad 7,5(1,3)$ (1)

\section{Hoofddiagnose}

Bijna de helft ( $47 \%$ ) van de ouderen afkomstig uit de eigen omgeving had als hoofddiagnose een psychische stoornis wat veelal neerkwam op dementie. Aandoeningen van het hartvaatstelsel, hetgeen meestal cerebrovasculaire aandoeningen (CVA) betekende, en nieuwvarmingen zijn daarna de meest voorkomende hoofddiagnoses (14\% resp. 12\%). Bij ouderen die vanuit een ziekenhuis werden opgenomen zijn de belangrijkste hoofddiagnoses: aandoeningen van het hartvaatstelsel (41\%), psychische stoornissen $(23 \%)$ en ongevalsletsels $(11 \%)$.

\section{Verschillen naar doel van de opname}

Uit het voorafgaande komt naar voren dat de hulpbehoefte en het sociale netwerk (afgezien van het op bezoek gaan bij anderen) van de op te nemen verpleeghuispatiënten niet verschilden naar aard van verblijf vóór de opname. De woonsituatie, het gebruik van professionele zorg, doel van de opname en de hoofddiagnoses waren daarentegen wel verschillend. Om meer inzicht te krijgen in de achtergronden van de verpleeghuisopnamen is vervolgens nagegaan of de geïnventariseerde kenmerken verschilden naar doel van de opname, onderscheiden naar aard van verblijf vóór de opname. Omdat de patiënten, bij wie het doel van de opname anders dan permanen- 
te ondersteuning of reactiveren was, een kleine en heterogene groep vormen, is deze hierbij buiten beschouwing gelaten. De vergeliking betreft dus 4 groepen, zoals aangegeven in tabel 7 .

Tabel 7. Kenmerken van de op te nemen verpleeghuispatienten naar doel van de opname en aard vari verblijf vóór de opname $(\%)^{\prime}$

Doel van de opname en aard van verblijf vór de opname $e^{2}$

$\begin{array}{lllll}\text { GROEP } 1 & \text { GROEP } 2 & \text { GROEP } 3 & \text { GROEP 4 } & \\ \text { (PO/EO) } & (\text { PO/Z) } & (\text { R/EO }) & (\text { R/Z }) & \text { Totaal } \\ (n=48) & (n=36) & (n=20) & (n=35) & (n=139)\end{array}$

Moning

huis niet gelijkvloers

huis gelijkvloers

bejaarden-/aanleunwoning

verzorgingshuis:

anders

(n)

(n)

$\begin{array}{rrrrr}13(27) & 16(44) & 14(70) & 21(60) & 64(46) \\ 7(15) & 9(25) & 2(10) & 7(20) & 25(18) \\ 2(4) & 2(6) & 1(5) & 4(11) & 9(6) \\ 25(52) & 9(25) & 3(15) & 3(9) & 40(29) \\ 1(2) & - & & - & 1(1)\end{array}$

Op bezoek gaan ${ }^{3 b}$

$\begin{array}{lrrrrr}0 & 32(67) & 20(56) & 16(80) & 10(29) & 78(56) \\ 1.4 & 7(14) & 12(33) & 4(20) & 5(14) & 28(20) \\ 5+ & 9(19) & 4(11) & - & 20(57) & 33(24)\end{array}$

Gebruik van professionele zorg ${ }^{30}$

geen professionele zorg

wijk- of gezinszorg

wijk- en gezinszorg

verzorgingshuis

$\begin{array}{rrrrr}1(2) & 18(53) & 4(20) & 17(48) & 40(29) \\ 14(29) & 3(9) & 8(40) & 14(40) & 39(29) \\ 8(17) & 4(12) & 5(25) & 1(3) & 18(13) \\ 25(52) & 9(26) & 3(15) & 3(9) & 40(29)\end{array}$

Hoofddiagnose 3 at

$\begin{array}{lccrrr}\text { psychische stoornissen } & 33(69) & 18(50) & 2(10) & - & 53(38) \\ \text { somatische hoofddiagnosen } & 15(31) & 18(50) & 18(90) & 35(100) & 86(62) \\ \text { waaronder: } & 5(10) & 13(36) & 3(15) & 15(43) & 36(26) \\ \text { hartvalstelsel } & 1(2) & 1(3) & 3(15) & 8(23) & 13(9) \\ \text { ongevalsiletsels } & 3(6) & - & 3(15) & 1(3) & 7(5) \\ \text { nieuwvormingen } & - & - & 2(10) & 5(14) & 7(5) \\ \text { aanvullende classificatie } & 4(8) & 1(3) & 1(5) & 1(3) & 7(5) \\ \text { zenuwstelsel/zintuigen } & - & - & 3(15) & 2(6) & 5(4) \\ \text { bewegingsstelsel } & 2(4) & 3(9) & 3(15) & 3(9) & 11(8) \\ \text { overig } & & & & \end{array}$

1 Hoewel het gebruik van percentages gezien de aantallen niet echt gleoorloofd is - "a percent is one out of a hundred" - worden ze omwille van de vergelijkbaarheid toch gepresenteerd.

$2 \mathrm{PO}=$ permanente ondersteuning; $\mathrm{A}=$ reactiveren; $E O=$ eigen omgeving; $Z$ = ziekenhuis

3 a $x^{2}=29.1 p<0.01 \quad$ b $x^{2}=36.3 p<0.001$

c $x^{2}=51,6 p<0.001 \quad$ d niet getoetst vanwege het aantal lege cellen 4 Tot deze categorie aandoeningen behoren ondermeer: status na heupoperatie; amputatiestatus en
overige status na operatie of orthopedische ingreep.

De groepen verschilden niet of nauwelijks naar de achtergrondkenmerken leeftijd, geslacht en burgerlijke staat, de ADL- en HHA-score en het sociale netwerk, met uitzondering van het op bezoek gaan. De groepen ouderen, afkomstig uit de eigen om- 
geving maar met een verschillend opnamedoel, verschilden eveneens niet in gebruik vam informele zorg. De woonsituatie, het op bezoek gaan, het gebruik van protessionele zorg en de hoofddiagnoses lieten wel verschillen zien; deze zijn in tabel 7 weergegeven. De groepen zijn dan als volgt te typeren. Van de groep ouderen, die vanuit de eigen omgeving voor permanente ondersteuning werd opgenomen (de grootste groepl, woonde ongeveer de helft woor de verpleeghuisopname in een verzorgingshuis. Op één na bleken allen die niet in een verzorgingshuis woonden, gebruik te ma. ken van professionele thuiszorg. Tweederde ging niet (meer) op bezoek bil anderen. De hoofddiagnose was bij eveneens tweederde van deze groep een psychische stoornis. Van de groep ouderen, die ook voor permanente ondersteuning werd opgenomen maar afkomstig is uit een ziekenhuis, woonde een kwart in een verzorgingshuis; ongeveer tweederde woonde in een normaal huis. Veelal werd door degenen die niet in een verzorgingshuis woonden géen gebruik gemaakt van professionele thuiszorg voorafgaand aan de ziekenthuisopname.

lets minder dan de helft ging nog op bezoek bij anderen. Ook bij deze groep is de meest voorkomende hoofddiagnose een psychische stoornis (50\%), maar ook aandoeningen van het hartvaatstelsel kwamen bij deze groep vaak voor (36\%). Van de groep ouderen, die vanuit de eigen omgeving ter reactivering werd opgenomen (de kleinste groep) "woonden de meesten voorafgaand aan de verpleeghuisopname in een normaal huis, waar zij vrij vaak hulp ontvingen van de gezinszorg en/of wijkverpleging. Het niet (meer) op bezoek gaan kwam bij deze groep het meest voor. Qua hoofddiagnoses is deze groep het meest divers, hoewel het bijna altijd om somatische diagnoses ging. Ook in de groep ouderen, die vanuit een ziekenhuis ter reactivering werd opgenomen, woonden de meesten in een normaal huls, veelal niet gelijkloers. De helft van hen maakte geen gebruik van professionele thuiszorg voorafgaand aan de ziekenhuisopname. De overigen maakten vooral gebruik van éen van de twee mogelijke vormen van professionele thuiszorg. Ruim tweederde ging voorafgaand aan de ziekenhuisopname nog op bezoek bij anderen. De hoofddiagnoses waren alle somatisch; de belangrijkste waren aandoeningen van het hartvaatstelsel $(43 \%)$ en ongevalsletsels (23\%). Impliciet in het woorafgaande (zie ook tabel 7 ) is dat patiënten uit het ziekenhuis $(n=71)$ vaker een somatische hoofddiagnose hadden dan de ouderen die vanuit de eigen omgeving kwamen $(n=68$; respectievelijk driekwart versus de helft) en daarmee samenhangend ook vaker voor reactivering werden opgenomen (de helft versus ruim een kwart).

\section{Disculssille}

Alvorens in te gaan op de verschillen tussen de onderscheiden groepen en de mogelikheden tot substitutie van zorg worden enkele onderzoeksgegevens vergeleken met landelijke cijfers. Ook wordt eerst aandacht besteed aan de schalen waarmee de hulpbehoefte gemeten is en aan het sociale netwerk van de op te nemen ouderen.

\section{Vergelijking met landelijke cijfers}

De hulpbehoevendheid van de op te nemen ouderen voorafgaand aan de verpleeghuisopname is groot. Dit is des te meer opmerkelijk omidat naar alle waarschijhlijkheid een ondervertegenwoordiging is opgetreden van patienten waarbij de situatie voorafgaand aan de opname moeilijk en complex was. Het gegeven dat de gemiddelde hulpindex van de patienten in het onderzoek zelfs nog een punt hoger ligt dan het landelijk gemiddelde, duidt erop dat het opnamebeleid in Maastricht, vanwege het aanvankelijke beddentekort, gericht was op de meest hulpbehoevenden. Ook ver- 
schillen in herkomst wijzen hierop. Landelik gezien was in $198729 \%$ afkomstig uit de eigen omgeving; ca. $60 \%$ werbleef voordien in een ziekenhuis of ander verpleeghuis en $11 \%$ woonde voorheen in een verzorgingshuis (SIG 1988). Voor de patienten in het onderzoek zijn de ciffers respectievelijk $30 \%, 50 \%$ en $20 \%$. Het uitsluiten van terminale patiênten, die vaker uit een ziekenhuis afkomstig zullen zijn, kan deze verschillen slechts ten dele verklaren: in 1988 werd $4.4 \%$ van de patienten voor terminale zorg opgenomen (SIG 1989). Het relatief grote aandeel van verzorgingshuisbewoners $(20 \%)$ duidt mogelijk op een inhaaleffekt. Overplaatsing naar een verpleeghuis vindt immers in het algemeen alleen plaats wanneer door de hulpbehoefte of gedragsstoornissen een te groot beroep gedaan wordt op het aanwezige personeel. Met de opening van het tweede verpleeghuis in Maastricht ontstond de ruimte deze hulpbehoevende verzorgingshuisbewoners daadwerkelijk op te nemen. De vergelijkbaarheid qua hulpbehoefte geeft uiteraard wel enige geruststelling over de generaliseerbaarheid wan onze bevindingen, maar is daar geen garantie voor. Inventarisatie van de door ons gevonden verbanden in andere verpleeghuizen is daarom gewenst.

\section{HHA- en ADL-schaal}

De frequentieverdelingen op de schalen waarmee de hulpbehoefte gemeten is, geven aan dat bij deze groep ouderen de ADL-schaal te verkiezen is boven de HHA-schaal, omdat de laatste nauwelijks differentiëert. Beide schalen zijn ook gebruikt in onderzoek bij thuiswonende ouderen, positief geindiceerden en verzorgingshuisbewoners. Bij deze groepen bleek de HHA-schaal beter te differentiëren, alhoewel bij de verzorgingshuisbewoners de ADL-score ook al een grotere spreiding liet zien (Frederiks 1990; Te Wierik en Frederiks 1990). Schaalanalyse van de gegevens van thuiswonende ouderen toonde aan dat beide schalen niet alleen afzonderlijk, maar ook gezamenlijk een hiërarchische structuur hebben. De gecombineerde schaal is niet duidelijk in een HHA- en ADL-deel te onderscheiden en lijkt dan ook één concept 'invaliditeit' te meten. Gebruik van de gecombineerde schaal zou betekenen dat verschillende groepen ouderen op het "invaliditeitscontinuum" verschillende posities innemen, met als voordeel dat die posities, vanwege de hiërarchische structuur, informatie geven over de aard van de hulpbehoefte (Frederiks 1990). De bevindingen bij de op te nemen verpleeghuispatiënten ondersteunen de ideeën over de bruikbaarheid van de gecombineerde schaal bij verschillende groepen ouderen.

\section{Soclaal netwerk}

Het sociale netwerk van de op te nemen ouderen is in het algemeen niet schraal te noemen. Uit vergelijking met gegevens van hulpbehoevende thuiswonende ouderen in Maastricht, Komt naar voren dat de op te nemen verpleeghuispatiënten wat vaker alleen woonden, vaker veel bezoek kregen maar veel minder zelf op bezoek gingen tijd van de op te nemen patiënten, evenals het feit dat relatief veel van hen in een verzorgingshuis woonde. De veel grotere hulpbehoefte van de op te nemen patiënten kan mogelijk het verschil in op bezoek gaan verklaren; op bezoek gaan meet immers voor een deel ook de mobiliteit. Voor het verschil in bezoek ontvangen zijn meerdere verklaringen mogelijk. Zo zou het niet meer op bezoek kunnen gaan gecompenseerd kunnen worden door (meer) bezaek van degenen waar men voorheen op bezoek kwam. Ook is mogelijk dat het bezoek van netwerk-leden (bijvoorbeeld kinderen) geintensiveerd is tengevolge van de toenemende hulpbehoefte. Een andere verkla-
ring, die niet is uit te sluiten, is dat juist ouderen met een zwak sociaal netwerk niet 
zijin aangemeld voor het onderzoek. Hoe het ook zij, deze bevindingen komen overeen met het onderzoek van Van den Bos, die geen aanwijzingen vond dat chronische ziekte bij ouderen leidt tot verzwakking van hun informele netwerken (Van den Bos 1989).

\section{Verschillen tussen de onderscheiden groepen patiënten}

De resultaten van de analyse naar doel van de opname en aard van verblijf vóór de cpname geven aan dat binnen de heterogene groep op te nemen patiënten vrij duidelijk subgroepen te onderscheiden zijn, alhoewel de achtergrondkenmerken, de hulpbehoefte en het sociale netwerk, met uitzondering van op bezoek gaan, niet bleken te verschillen. De subgroepen worden vooral onderscheiden door de aard van de aandoeningen (psychogeriatrisch versus somatisch en chronisch versus min of meer acuut), hetgeen niet alleen uit de hoofddiagnose zelf, maar ook uit de verschillen in woonsituatie, het op bezoek gaan en het zorggebruik naar voren komt. voor verdere subgroepanalyse, waarin verbanden met andere factoren duidelijk kunnen worden, zijn de groepen helaas te klein.

De kenmerken van de groep ouderen die vanuit de eigen omgeving voor permanente ondersteuning werd opgenomen suggereren dat ten gevolge van chronische aandoeningen zoals dementie, de hulpbehoefte en/of gedragsstoornissen dermate groot c.q. storend zijn dat langer verblijf in de eigen omgeving of het verzorgingshuis niet meer mogelijk was, ondanks de aanwezigheid van professionele zorg. Bij do groep ouderen, die afkomstig zijn uit een ziekenhuis en die voor permanente ondersteuning opgenomen werden, wijzen de kenmerken in de richting van een min of meer plotselinge verslechtering van de gezondheidstoestand die een ziekenhuisopname en de daarop volgende verpleeghuisopname nodig maakte. De prognose van de gezondheidstoestand bepaalt in het algemeen het doel van de opname. Bij psychische stoornissen (de meest voorkomende hoofddiagnose in deze groep) is dat vrijwel altijd permanente ondersteuning. Bij aandoeningen van het hartvaatstelsel (de tweede belangrijke hoofddiagnose) is het doel in het algemeen minder eenduidig. Bekend is dat een deel van deze patiënten na reactivering ontslagen kan worden en dat de rest langdurig blijft opgenomen (Ribbe en Van Mens 1986). Mogelijk was bij de patiënten in deze subgroep de prognose dermate slecht dat reactiveren niet meer mogelijk leek.

Bij ouderen die vanuit de eigen omgeving ter reactivering werden opgenomen lijkt de verpleeghuisopname het vervolg op een al langer durend ziekte proces, waarbij de aard en de prognose van de diverse aandoeningen functioverbetering niet uitsloten. Bij de ouderen die afkomstig waren uit het ziekenhuis en die ter reactivering werden opgenomen lijken met name ernstige acute aandoeningen zoals een CVA of ongevalsletsel, de bepalende factor voor de opnamen in zowel ziekenhuis als verpleeghuis te zijn.

\section{Substitutie}

Het voorgestelde substitutiebeleid voor verpleeghuispatiënten heeft met name betrekking op de patiënten die voor permanente ondersteuning worden opgenomen. Afhankelijk van de diagnose worden verschillende alternatieven voorgesteld. Voor patiënten met psychische stoornissen wordt geschat dat ongeveer $10 \%$ ook in een beschermde woonvorm, zoals ontwikkeld door verpleeghuis de Landrijt te Eindhoven, zou kunnen verblijven (Duine en Peters 1987). Vooralsnog is de beschikbaarheid van deze woonvormen gering. Voor patiënten met somatische diagnoses wordt vooral verblijt in een 
verzorgingshuis of voortgezet verblijf thuis met (meer) professionele zorg mogelijk geacht (Commissie Structuur en Financiering Gezondheidszorg 1987; Mootz et al. 1986; Pernmen 1985). Van de somatische patienten in ons onderzoek zou dan een kleine $40 \%$ in aanmerking komen voor substitutie (het betreft 33 ouderen uit groep 1 en 2 met somatische hoofddiagnoses op de totale groep van 86 somatische patiënten, zie tabel 7). De mate van hulpbehoevendheid en het al aanwezige gebruik van zorg doen echter vermoeden dat substitutie slechts in een beperkt aantal gevallen mogelijk zal zijn. Immers, zo men niet al in een verzorgingshuis woonde, maakte men naast informele zorg vaak al gebruik van professionele thuiszorg. Meer zorg of uitbreiding van de zorg tot beide vormen van thuiszorg, indien men gebruik maakte van éen van beide vormen, zal beperkt effect hebben. De meesten hadden immers 3 of meer ADL-beperkingen. Vanwege de hiërarchische structuur houdt dit veelal in dat men naast het huishoudien, tenminste hulp nodig heeft bij wassen, aan-en uitkleden en in en uit bed gaan. Bij deze beperkingen is twee keer per dag ADL-ondersteuning nodig. Bij meer beperkingen is hulp bij toiletgebruik en binnenshuis verplaatsen nodig, hetgeen impliceert dat ADL-ondersteuning op verschillende tijdstippen gedurende de dag nodig is. Ondanks de 24-uurs bereikbaarheid is professionele thuiszorg allén niet valdoende om hierin te voorzien. Informele zorg, die al in hoge mate verleend werd, blijft van cruciaal belang. Het door Coolen beschreven fenomeen, dat substitutie alleen mogelijk is boven een bepaald basisaanbod van een voorziening, lijkt hier dan ook van toepassing (Coolen 1980). Bij voortschrijdende hulpbehoefte wordt het beroep op de informele zorgverleners - niet alleen bij alleenwonenden, maar ook bij samenwonenden - mogelijk zo groot, dat alleen uitstel van opname bewerkstelligd kan worden.

Het gegeven dat de helft van de patiënten die vanuit de eigen omgeving voor permanente ondersteuning werden opgenomen in een verzorgingshuis woonde (18\% van de totale groep), is een ander aanknopingspunt voor substitutie. Voor deze patiënten zou ondersteuning van het verzorgingshuis door het verpleeghuis wellicht de extra zorg, die deze ouderen met vaak psychische problemen nodig hebben, kunnen realiseren. Hierdoor zou de 'laatste gang' naar het verpleeghuis voor deze ouderen niet meer nodig zijn. Momenteel worden experimenten met deze 'outreaching' taak van het verpleeghuis door middel van subsidies gefaciliteerd (Ministerie van WVC 1989). De resultaten ervan zullen uitwijzen of deze vorm van substitutie inderdaad mogelijk is.

Samenvattend kan gesteld worden dat de op te nemen ouderen, onderscheiden naar aard van verblijf vóor en doel van de opname vrij duidelijk verschillen in hoofddiagnoses, woonsituatie, het op bezoek gaan en het gebruik van zorg voorafgaand aan de opname. De aard en de prognose van de aandoeningen lijken, evenals de hulpbehoefte, een belangrijke rol te spelen bij de verpleeghuisopname. In theorie zou substitutie mogelijk zijn bij ouderen, opgenomen woor permanente ondersteuning, met somatische hoofddiagnoses of lichtere psychogeriatrische problematiek. Gezien de zware hulpbehoefte en het al aanwezige gebruik van zowel informele als professionele zorg, naast een tekort aan alternatieve woonvormen, lijken de substitutiemogelijkheden voor deze groep ouderen in werkelijkheid evenwel zeer beperkt. 


\section{Literatuiur}

De Amsterdamse bejaarden in 1976. Amsterdam, Veldkamp Marktonderzoek BV 1977.

Bisscheroux PFLA, Frederiks CMA. Ouderen en het gebruik van professionele zorg; een vergelijking van kenmerken van thuiswonende ouderen en bewoners van verzorgingstehuizen in Geleen. Maastricht, Rijksuniversiteit Limburg 1986.

Bos GAM van den. Zorgen van en voor chronisch zieken. Proefschrift Universiteit van Amsterdam, Amsterdam 1989.

Commissie Structuur en Financiering Gezondheidszorg. Bereidheid tot verandering. Den Haag, DOP 1987.

Coolen JAl. Samenhang van voorzieningen voor bejaarden. Sociologische Gids 1980; 27: 47-66.

Duine TJ, Peters HJM. Genormaliseerd Wonen - een incident? Een onderzoek naar de omvang van de doelgroep voor Genormaliseerd Wonen in verpleeghuizen en groepsverzorgingsafdelingen van verzorgingstehuizen. Tijdschrift voor Gerontologie en Geriatrie 1987; 18: 225-231.

Frederiks CMA. Zorgbehoefte van en zorgverlening aan ouderen. Proefschrift Rijksuniversiteit Limburg, Maastricht 1990.

Ministerie van WVC. Financieel Overzicht Zorg 1990. Den Haag, Staatsuitgeverij 1989.

Ministerie van WVC. Financieel Overzicht Zorg 1991. Den Haag, Staatsuitgeverij 1990.

Ministerie van WVC. Zorg voor ouderen. Den Haag, Staatsuitgeverij 1986.

Mootz $M_{3}$ Timmermans J, Schoenmakers-Salkinoja J, Hessing-Wagner J. Samenhang in Zorg. Substitutiemogelijkheden op een viertal terreinen. Rijswijk, Sociaal Cultureel Planbureau 1986.

Remmen JWM. Bejaardenoordbewoners of verpleeghuispatiënten? Hoogezand, Uitgeverij Stubeg 1985.

Ribbe MW, Mens JTh van. Enkele kenmerken van verpleeghuispatiënten. Nederlands Tijdschrift voor Geneeskunde 1986; 130: 642-646.

SIG. Gebruikershandboek SIVIS. Utrecht, SIG 1984.

SIG. SIVIS jaarboek 1987. Utrecht, SIG 1988.

SIG. Jaarboek verpleeghuizen 1988. Utrecht, SIG 1989.

Wierik MJM te, Frederiks CMA. De hulpbehoefte en opnamewens van positief geindiceerden; een vergelijking met verzorgingshuisbewoners. Tijdschrift voor Gerontologie en Geriatrie 1990; 21: 115-123. 

HOOFDSTUK 4

DE HULPBEHOEFTE EN OPNAMEWENS VAN POSITIEF GEINDICEERDEN VOOR HET VERZORGINGSHUIS;

EEN VERGELIJKING MET VERZORGINGSHUISBEWONERS*

Margreet JM te Wierik, Carla MA Frederiks 


\section{Samenvatting}

De hulpbehoefte, het zorggebruik en de opnamewens van 135 ouderen met een positieve indicatie voor opname in een verzorgingshuis worden gepresenteerd. Nagegaan is hoe deze factoren onderling samenhingen en in hoeverre de hulpbehoefte van de positief geindiceerden verschilde van die van 207 verzorgingshuisbewoners. Naarmate de positief geindiceerden meer huishoudelijke beperkingen hadden namen depressieve klachten, geheugenstoornissen en, zoals verwacht, het gebruik van professionele en informele zorg toe. De hulpbehoefte van de positief geindiceerden was minstens zo groot als die van verzorgingshuisbewoners. Zij hadden (bijna) Evenveel huishoudelijke en ADL-beperkingen en zelfs meer eenzaamheidsgevoelens en depressieve klachten. Toch kan woor de positief geindiceerden met weinig huishoudelijke beperkingen de noodzaak wan opname betwijfeld worden. De wens om op korte termijn opgenomen te worden was namelijk sterk geassocieerd met depressieve klachten en eenzaamheidsgevoelens. Mits extramuraal een effectieve aanpak gevonden wordt voor deze geestelifke problematiek kan (meer) thuiszorg voor hen een alternatief zijn.

\section{Summary}

\section{Care needs and desire to be admitted among applicants to homes for the aged; a comparison with residents of such homes}

For 135 applicants to homes for the aged, the care needs, utilization of care and desire to be admitted in the short or long term are presented and their interrelations considered. The care needs of the applicants to homes for the aged are compared with those of 207 residents of such homes. Increasing numbers of housekeeping disabilities were correlated with increasing depressive complaints, memory disturbances and, obiously, the use of formal and informal care. The care needs of the applicants were at least as great as those of the residents. They had (nearly) as many housekeeping and ADL disabilities and even more feelings of loneliness and depressive complaints. Nevertheless, the necessity of admission to a home for the aged can be questioned for those applicants with few housekeeping disabilities; the desire to be admitted at short notice was strongly associated with depressive complaints and feelings of loneliness. Provided these mental problems can be handled effectively. (more) home care could be a realistic alternative for such people. 


\section{Inleiding}

Het ouderenbeleid staat sinds een aantal jaren in het teken van het zo lang mogelijk zelfstandig functioneren van ouderen. Naast zorginhoudelike overwegingen wordt dit streven ingegeven door het toenemend aantal ouderen, waardoor, bij ongewijzigd beleid, de kosten voor de ouderenzorg sterk zullen stijgen. Substitutie van zorg. versterking van de eerste lijn en een relatieve beperking van de intramurale capaciteit. zijn sleutelbegrippen in de diverse beleidsnota's over de zorg voor ouderen (Ministerie van WVC 1986 en 1989; Mootz et al. 1986).

Om na te gaan in hoeverre substitutie werkelijk mogelijk is, is inzicht nodig in de mate waarin andere factoren, naast de mate van invaliditeit, van invloed zijn op het gebruik van zorgvoorzieningen. In Maastricht is een onderzoek uitgevoerd naar het verschillend gebruilk van voorzieningen door ouderen met een gelijke mate van invaliditeit. In dit artikel zullen enige gegevens gepresenteend worden over ouderen die positief geindiceerd zijn voor een verzorgingshuis en ouderen die reeds in een verzorgingshuis verblijven. Alvorens de hierbij gehanteerde vraagstellingen te presenteren worden eerst enige achtergronden van de indicatiestelling voor verzorgingshuizen ge. schetst.

Sinds 1977 dienen de aanvragen voor opname in een verzorgingshuis beoordeeld te worden door de gemeentelijke indicatiecommissies.* Deze commissies zijn onder meer ingesteld om te bewerkstelligen dat alleen ouderen met een welomschreven hulpbehoefte worden opgenomen. Hun taak is dan ook om te bepalen of, en zo ja, met welke urgentie, de aanvrager in aanmerking komt voor opname. De hulpbehoefte en de aanwezige hulp zijn daarbij de belangrijkste criteria. Van Overbeek (1983) evalueerde het functioneren van de indicatiecommissies en concludeerde dat het indicatiesysteem entoe heeft geleid dat opname beperkt blijft tot ouderen die niet meer zelfstandig kunnen wonen omdat alleen zij een positieve indicatie krijgen. Het is echter (nog) niet zo dat de beoordeling van de aanvragen op uniforme wijze plaatsvindt. Als oorzaken hiervan worden genoemd de gedetailleerdheid van het indicatiesysteem, de invloed van het voorzieningenpakket ter plaatse en het feit dat bij de urgentiebepaling geen rekening gehouden kan worden met de opnamewens van de aanvrager, Ook Coolen en van Pelt (1985) kwamen tot de conclusie dat de aanvragen door de indica* tiecommissies niet op gelijke wijze beoordeeld worden. In tegenstelling tot Van Overbeek (1983) vonden zij dat de toekenning van zowel een positieve indicatie als van een hoge urgentie niet alleen af bleek te hangen van de verzorgingsbehoefte, maar met name ook van de opnamewens van de oudere.

Sinds 1977 is de gemiddelde leeftijd en de hulpbehoefte bij opname geleidelijk aan toegenomen. Tijdens het verblijf neemt de hulpbehoefte van de verzorgingshuisbewoners verder toe. De gemiddelde verblijfsduur is afgenomen. Het verzorgingshuis is hiermee veranderd van een vervangende woonvorm voor vitale ouderen in een woonvorm waar hulpbehoevende ouderen langdurig verzorgd worden. Omdat de hulpbehoevendheid van verzorgingshuisbewoners groot is, is het verzorgingshuis voor redelijk vitale ouderen geen aantrekkelijke woonvorm meer (Van Loveren-Huyben et a:. 1985; Huijsman 1988; Zweens-ten Kate 1985).

Samenvattend heeft het indicatiesysteem ertoe bijgedragen dat de hulpbehoefte van verzorgingshuisbewoners in de afgelopen jaren is toegenomen. Niettemin blijkt bij de indicatiestelling de opnamewens van de oudere ook een belangrijke rol te spelen.

* Ten tijde van het onderzoek was er nog geen sprake van de, sinds 1 januari 1989, gewijzigde taakstelling en werkwijze van de indicatiecommissies. 
In dit artikel worden de hulpbehoefte en het zorggebruik van een groep positief geindiceerden weergegeven. Om inzicht te krijgen in de achtergronden van de aanvraag tot opname wordt nagegaan hoe verschillende aspecten van de hulpbehoefte, het zorggebruik en de opnamewens onderling samenhangen. Tevens wordt de hulpbehoefte van positief geïndiceerden vergeleken met die van verzorgingshuisbewoners. De verwachting daarbij is dat de hulpbehoefte van de positief geîndiceerden geringer is dan die van de verzorgingshuissbewoners. Niet alleen omdat niet alle geindiceerden op korte termijn worden opgenomen (bv. vanwege de wachtlijst) en hun hulpbehoefte eerder toe dan af zal nemen in de periode tot opname, maar ook omdat de hulpbehoefte van individuele verzorgingshuisbewoners tijdens het verblijf verder toeneemt (Van Loveren-Huyben et al. 1985; Huijsman 1988). In de discussie worden de bevindingen besproken en wordt ingegaan op de vraag of er alternatieven zijn voor opname in een verzorgingshuis.

\section{Opzet en uitvoering van het onderzoek}

Het veldwerk voor het onderzoek bij 135 positief geindiceerde ouderen vond plaats in Maastricht gedurende de periode november 1986 tot en met mei 1988. Zij werden omwille van de privacy eerst door de maatschappelijk werkenden van de indicatiecommissie tijdens het huisbezoek orm medewerking gevraagd. Wanneer deze geweigerd werd of wanneer iemand op grond van zijn/haar situatie niet gevraagd werd door de maatschappelijk werkenden, werd de reden daarvan genoteerd. Deze procedure heeft geleid tot een grote uitval: slechts zo'n $40 \%$ van de geindiceerden werd aangemeld. Een belangrijke reden hiervoor was dat het vragen om medewerking als moeilijk en conflicterend met het eigenlijke doel van het huisbezoek ervaren werd. Voor het niet aanmelden werden de volgende redenen gegeven: $40 \%$ weigerde een interview, bij $38 \%$ vormde de geestelijke toestand een belemmering. bij $6 \%$ de lichamelijke toestand en bij $16 \%$ speelden andere factoren een rol. Bij $83 \%$ van de aangemelde cuderen werd een interview afgenomen. Het alsnog weigeren van een interview of een te slechte lichamelijke conditie waren de belangrijkste redenen voor deze nonrespons. Door de terughoudendheid van de indicatiecommissie zijn met name positief geïndiceerden met geestelijke problematiek ondervertegenwoordigd.

De gegevens zijn verzameld door middel van mondelinge interviews. Met een gestructureerde vragenlijst werd informatie verkregen over de mate van invaliditeit, de geestelijke toestand, de gezondheid en het gebruik van zorg. Ook werd gevraagd naar de reden van de aanvraag voor opname en de termijn waarop men naar het verzorgingshuis will. De vragenlijst is in een pilotstudie uitgetest en bruikbaar bevonden. De interviews werden door getrainde interviewers bij de respondenten thuis afgenomen. In tabel 1 zijn de variabelen en hun operationalisaties weergegeven; waar relevant zijn
tevens de schaaltechnische gegevens vermeld.

De gegevens van 207 verzorgingshuisbewoners zijn afkomstig van een aselecte steekproef van Maastrichtse verzorgingshuisbewoners. In 1987 zijn zij met behulp van
dezelfde vragenlijst geînterviewd. De respons bij deze groep bedroeg $71 \%$. Bij de helft
van de nonrespondenten liet hun lichamelijke of van de nonrespondenten liet hun lichamelijke of geestelijke toestand een interview niet
toe; de andere helft weigerde een interview (Frederiks et al. 1988).
De gegevens zijn op verschillende manier

De gegevens zijn op verschillende manieren geanalyseerd. De sterkte van de onderlinge verbanden tussen de verschillende aspecten van de hulpbehoefte, het zorggebruik en de opnamewens is eerst bivariaat bepaald met behulp van Kendall's tau, wens bleken aldus geassocieerd te ziin. Het informele zorggebruik en de opnamesamenhingen. Om na te gaan welke variabelen het meeste samenhingen met het 
informele zorggebruik respectievelijk de opnamewens, zijn vervolgens multivariate stapsgewijze regressie analyses uitgevoerd. Bij de toetsing van de hypothese dat de positief geindiceerden minder hulpbehoevend zijn dan de verzorgingshuisbewoners is gebruik gemaakt van de toets verschillen tusssen proporties en die ongepaarde ttoets voor gemiddelden.

Tabet 1. De onderzoekswariabielen en thun oparationalisaties

Variabelen

Operationalisatie nange ert Cronbach"s a

Achtergrondkenmerken

Peden voot de anvaag

Opnamewerns:

Hulpbehaofte

Huishoudalijke
invaliditeit

Lïchaintelike

invaliditeit

Eenzaarnheidsgovoelems

Depressieve klachten

Geheugenstoornissem

Gezondheidsbeleving

Aanwezigheld chronische zieliste of handicap

Medicijagebruik

\section{Het gebrulk van zorg}

Protomatomén zorg

Intormele zorg bij

het huishourden

Intormele zorg bil A ADL

Behoefte ana (mear) hulp
Leeftita

Geslacht

Burgerifike stat

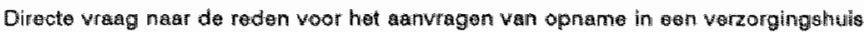

Wragg naar do tormifin waarop men naas oan verzorgingshubs whil

HHA-score = de som wan 9 hulshoudelijke activiteiten die mon niet zelfstandig kan uitwooren; hot belreft koken, oen brocdmealitijd kisar maken, stof atnemen an atwasisen, dweilen on ramen lappen, de werwarming verzorgon, boodschappen doan, die wrac doen, bedden opmaken on do administratie bihoudion; range: $0-\theta_{i} \alpha=0.67$

AOL-score = de som van B A.L-activiteiten die men niet zelfstandig kan verrichten; het betreft in

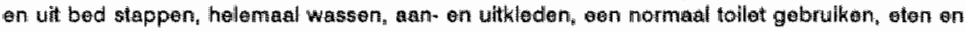
drimken en birnenshuis verplaatsen; range: $0-8 ; \alpha=0.60$

Directe wraag naar het wórkomen van enzaamtheidsgewowens

Zung's Solf Fating Deprassion Scalle (1965): 20 ultsprakan mot oll 4 antwoordmogolijkhedem: range: $20.80^{\text {th }} ; a=0.82$

Abbrewigted Mental Test van Qureshi en Hodkinson (1974): 10 wragen m, b.t. korte on Hange termilim gehewgen, inprentingswermogen on oriëntati r range: $0.10^{\circ} ; \alpha=0.63$

Oordeal over de eigen gozondheid in vergelijking met laeftujdgenaten

Directe wrasg naar die aenwezigheid van een chronische aandooning of handicap

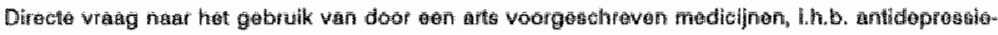
we an saderende modielinan

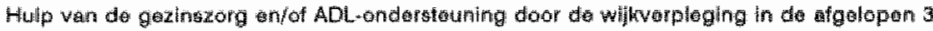
maxingen

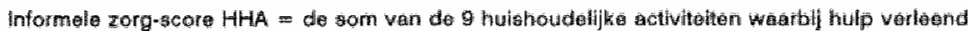

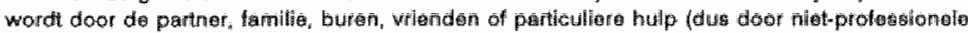

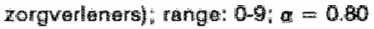

Intormele zorg-score $\mathrm{ADL}=$ de familie, buren, vriendem of particuliera hulp (dus door niet-professionele zergwerleners); range: $0-8: a=0.64$

Directe wrag nagi zaken warvoor men (moer) hulp zou kunnon gobruilken

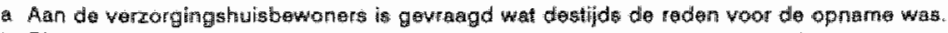

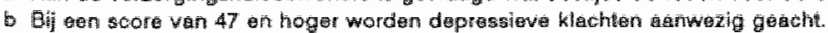

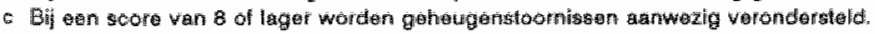




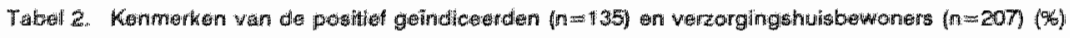

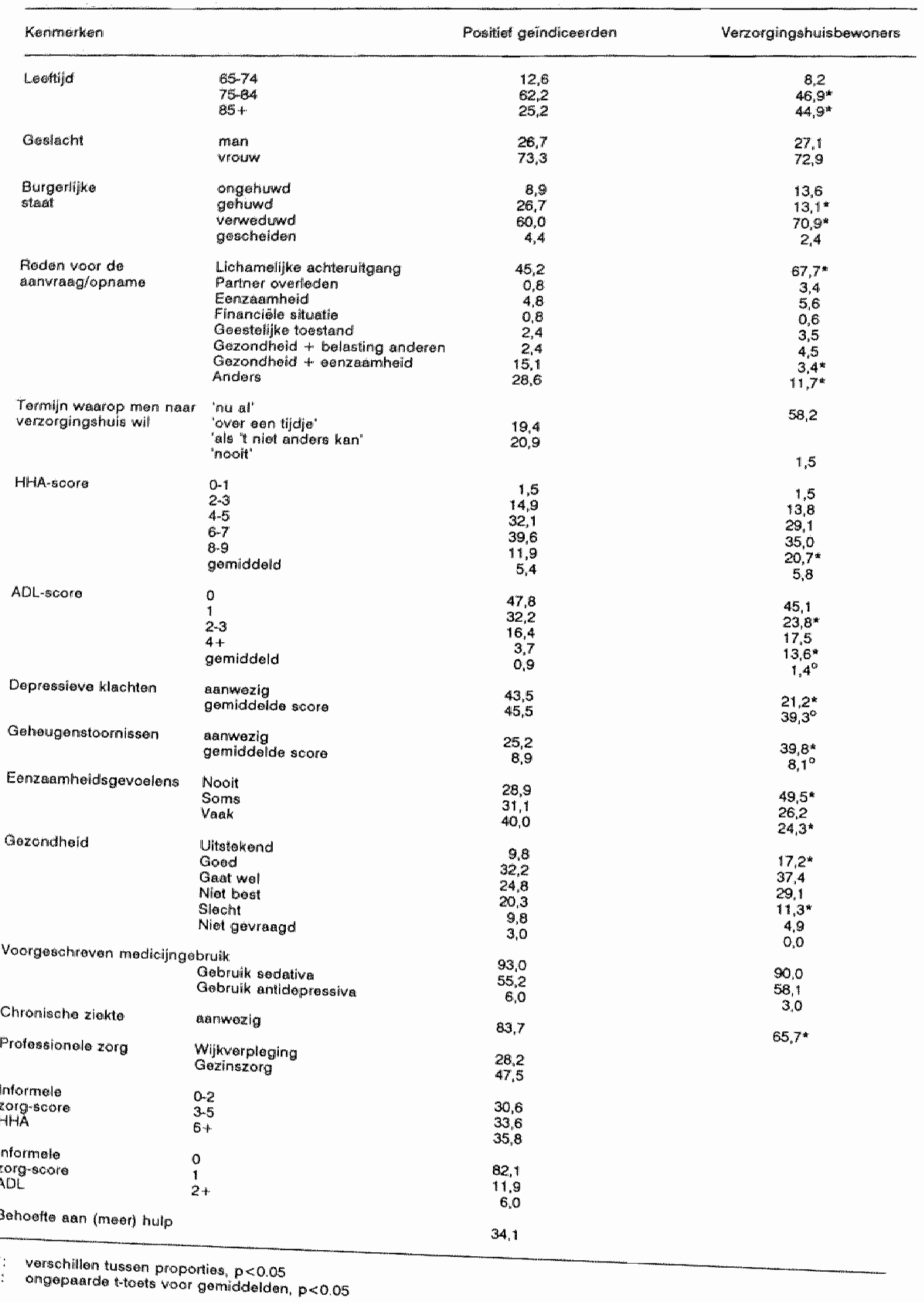




\section{Resultaten}

\section{De hulpbehoefte en thet zorggebruik}

De frequentieverdelingen van de kenmerken van de geindiceerden zijn in tabel 2 weergegeven. De groep ondervraagden bestond woor een groot deel uit alleenstaande, oudere vrouwen. De belangrijkste reden voor de aanvraag was lichamelijke achteruitgang. Ruim de helft wilde op zo kort mogelijke termijn opgenomen worden in het verzorgingshuis. Het merendeel kon het huishouden grotendeels niet meer zelf verzorgen en vaak leverden ook één of meer ADL-activiteiten problemen op. Depressieve klachten en sterke eenzaamheidsgevoelens waren veel voorkomende problemen. De eigen gezondheid werd wrij positief beoordeeld, ondanks de veelvuldige aanwezigheid van een chronische ziekte of handicap. Bijna de helft van de ouderen had hulp van de gezinszarg; van de wijkverpleging werd minder gebruik gemaakt (28\%). Het gebruik van informele zorg bij het huishouden is aanzienlijk; slechts $5 \%$ had geen en $25 \%$ had weinig informele zorg (score 1-2). Gebruik van informele zorg bij de ADL kwam veell minder voor: slechts $18 \%$ ontwing informele zorg bij één of meer ADLactiviteiten. Behoefte aan (meer) hulp werd slechts door een derde van de ondervraagden aangegeven. Bij de specificatie daarvan viel op dat hulp bij zwaar huishoudelijk werk ongeveer even vaak genoemd werd als gezelschap ( $\pm 10 \%$ ).

\section{Onderlinge samenhangen}

De onderlinge samenhang tussen verschillende aspecten van de hulpbehoefte, het zorggebruik en de opnamewens van de positief geindiceerden wordt hieronder geëxploreerd.

In tabel 3 is het vóórkomen van geestelijke probllematiek weergegeven naar de mate van invaliditeit. Invaliditeit is hierbij beperkt tot de HHA-score omdat deze score beter differentieerde dan de ADL-score. De samenhang tussen de HHA- en ADL-score was overigens hoog $(r=0.50)$. * De HHA-score hing zwak samen met depressieve klachten en geheugenstoornissen. Bij veel huishoudelijke beperkingen (score 6 en hoger) werd bij meer dan de helft depressieve klachten aangetroffen en bij een derde geheugenstoornissen; er was geen relatie tussen de HHA-score en eenzaamheidsgevoelens.

Geestelijke problematiek toonde geen verband met het gebruilk van professionele zorg, i.c. hulp van de gezinszorg en/of wilkverpleging. De gebruikers van professionele zorg verschilden nauwelijks van de niet-gebruikers wat betreft de aanwezigheid van depressieve klachten, geheugenstoornissen en eenzaamheidsgevoelens. Eenzaamheidsgevoelens lieten wel een negatief verband zien met het gebruik van informele zorg bij het huishouden** (tabel 4): naarmate er meer informele zorg aanwezig was kwamen eenzaamheidsgevoelens minder vaak voor. Ook voor depressieve klachten was deze trend waar te nemen.

- Wanneer een associatiemaat gepresenteerd wordt is de overschrijdingskans altijd kleiner dan 0.05 .

* Het gebruik van informele zorg bij de ADL blijft hier verder buiten beschouwing vanwege de scheve verdeling ervan. 
Tabel 3. Depressieve klachten ${ }_{4}$ geheugenstoonissen en eenzaamheidsgevoelens naar HHA-score bij posititief geindiceerden $(\%)$

\begin{tabular}{|c|c|c|c|c|c|c|c|}
\hline \multirow[b]{2}{*}{$\begin{array}{l}\text { HHA- } \\
\text { score }\end{array}$} & \multicolumn{2}{|c|}{$\begin{array}{l}\text { Depressiove } \\
\text { "klachten' }\end{array}$} & \multicolumn{2}{|c|}{$\begin{array}{l}\text { Geheugen- } \\
\text { stoornissen? }\end{array}$} & \multicolumn{3}{|c|}{$\begin{array}{l}\text { Eenzaamheids- } \\
\text { gevoelens }\end{array}$} \\
\hline & ałwezig & aanwezig & afwezig & aanwezig & nooit & soms & waak \\
\hline 0.3 & 55 & 45 & 95 & 5 & 18 & 46 & 36 \\
\hline $4-5$ & 74 & 26 & 77 & 23 & 40 & 23 & 37 \\
\hline $6-7$ & 49 & 51 & 67 & 33 & 23 & 32 & 45 \\
\hline $8-9$ & 33 & 67 & 67 & 33 & 31 & 31 & 38 \\
\hline Totaal & 57 & 44 & 75 & 25 & 29 & 31 & 40 \\
\hline
\end{tabular}

1 Kendall's tau $=0.21 p<0.02$

2 Kendall's tau $=0.21 p<0.01$

3 Kendall's tau $=0.03 p>0.30$

Tabel 4. Depressieve klachten, geheugenstoornissen en eenzaamheidsgevoelens naar informele zorg bij positief geíndiceerden $(\%)$

\begin{tabular}{|c|c|c|c|c|c|c|c|}
\hline \multirow{2}{*}{$\begin{array}{l}\text { Informele } \\
\text { Zorg-score } \\
\text { HHA }\end{array}$} & \multicolumn{2}{|c|}{$\begin{array}{l}\text { Depressieve } \\
\text { klachten' }\end{array}$} & \multicolumn{2}{|c|}{$\begin{array}{l}\text { Geheugen- } \\
\text { stoornissen }\end{array}$} & \multicolumn{3}{|c|}{$\begin{array}{l}\text { Eenzaamheids- } \\
\text { gevoelens }^{3}\end{array}$} \\
\hline & afwezig & aanwezig & afwezig & aanwezig & nooit & soms & vaak \\
\hline 0.2 & 44 & 56 & 73 & 27 & 9 & 42 & 49 \\
\hline 3-5 & 64 & 36 & 75 & 25 & 27 & 31 & 42 \\
\hline $6+$ & 61 & 39 & 76 & 24 & 46 & 23 & 31 \\
\hline Total & 56 & 44 & 75 & 25 & 29 & 31 & 40 \\
\hline
\end{tabular}

1 Kendall's tau $=0.15 p<0.06$

2 Kendall's tau $=-0.03 p>0.40$

3 Kendall's tau $=-0.23 \mathrm{p}<0.01$

Het gebruik van professionele zorg hing, zoals te verwachten was, positief samen met zowel de ADL-als HHA-score. Het gebruik van professionele zorg steeg van $36 \%$ bij een ADL-score van 0 tot $74 \%$ bij een ADL-score van 2 en hoger (Kendall's tau = 0.35). Het verband met de HHA-score was minder sterk: het percentage gebruikers nam toe van $45 \%$ bij een HHA-score van $0-3$ tot $62 \%$ bij een HHA-score van $8-9$ (Kendall's tau $=0.19$ ). Tussen het gebruik van professionele en informele zorg be. stond een negatief verband. Bij afwezigheid van professionele zorg is meer informele zorg aanwezig en omgekeerd (Kendall's tau $=-0.33$ ). Deze samenhang was sterker bij veel huishoudelijke beperkingen; in vergelijking met minder beperkingen kwam 
gebruik van (redelijk) veel informele én professionele zorg vaker voor (tabel 5). De gezondheidsbeleving liet een voor de hand liggend verband zien met zowel de ADLals de HHA-score. Bij hogere scores werd de eigen gezondheid negatiever beoordeeld (Kendall's tau $=0.23$ resp. 0.25 ). De relatie van de gezondheidsbeleving met depressieve klachten en eenzaamheidsgevoelens was echter veel sterker (tabel 6). De gezondheidsbeleving hing zwak samen met het gebruik van professionelle zorg (Kendall's tau $=-0.16$ ); er was geen associatie met het gebruik van informele zorg.

Tabel 5. Het gebruik van professionele en informele zorg naar HHA-score bij positief geindiceerden (\%)
HHA-score $0-5^{\prime \prime}$
HHA-score $6-9^{2}$
professionele hulp
professionele hulp

Informele

zorg-score

HHA

afwezig

aanwrezig

afwezig

aanwezig

$\begin{array}{rrrrr}0-2 & 30 & 70 & 5 & 95 \\ 3-5 & 70 & 30 & 53 & 47 \\ 6+ & 67 & 33 & 52 & 48\end{array}$

Totaal

57

43

37

62

1 Kendall's tau $=-0.31 \quad p<0.01$

2 Kendall's tau $=-0.41 \quad p<0.01$

Tabel 6. Depressieve klachten en eenzaamheidsgevoelens naar gezondheidsbeleving bil positief geîndiceerden $(\%)$

Depressieve Klachten' Eenzaamheidsgevoelens"

\begin{tabular}{|c|c|c|c|c|c|}
\hline \multirow[b]{2}{*}{ Gezondheidsbeleving } & \multicolumn{2}{|c|}{ Depressieve klachten" } & \multicolumn{3}{|c|}{ Eenzaamheidsgevoelens ${ }^{2}$} \\
\hline & afwezig & aanwezig & nooit & soms & waak \\
\hline Uitstekend/goed & 88 & 12 & 45 & 39 & 16 \\
\hline Gaat wel & 49 & 52 & 24 & 27 & 49 \\
\hline Niet best/slecht & 21 & 79 & 10 & 25 & 65 \\
\hline Totaal & 58 & 43 & 29 & 31 & 40 \\
\hline
\end{tabular}

1 Kendall"s tau $=0.62 p<0.01$

2 Kendall's tau $=0.40 p<0.01$

De opnamewens, afgeleid van de termijn waarop men naar het verzorgingshuis wil, vertoonde een vrij sterke negatieve samenhang met de gezondheidsbeleving (Kendall's tau $=-0.38$ ). Dit is niet zo verwonderlijk: een ruime meerderheid noemde 
immers een slechter wordende gezondheid als (een van) de reden(en) voor de aanvraag. Opmerkelik is dat de opnamewens veel sterker samenhing met eenzaamheidsgevoelens en depressieve klachten dan met de HHA-score (tabel 7); er was geen samenhang met de ADL-score, geheugenstoornissen en het gebruik van professionele en informele zorg.

Tabei 7. De opnamewens naar HHA-score, eenzaamheidsgevoelens en depressieve klachten bij positiel geiindiceerden (\%)

\begin{tabular}{|c|c|c|c|c|c|c|c|}
\hline \multirow[b]{2}{*}{ Opnamewens } & \multicolumn{2}{|c|}{ HHA-score ${ }^{\|}$} & \multicolumn{3}{|c|}{ Eenzaamheidsgevoelens ${ }^{2}$} & \multicolumn{2}{|c|}{ Depressieve klachten ${ }^{3}$} \\
\hline & $0-5$ & $6-9$ & nooit & soms & vaak & afwezig & aarwwezig \\
\hline Op konte termijn & 42 & 58 & 18 & 27 & 55 & 42 & 58 \\
\hline Op langare termijn & 57 & 43 & 45 & 37 & 18 & 77 & 23 \\
\hline Total & 48 & 52 & 29 & 31 & 40 & 56 & 44 \\
\hline
\end{tabular}

1 Kendall's tau $=0.15$ p $<0.04$

2 Kendall's tau $=-0.41 \quad p<0.01$

3 Kendali's tau $=-0.34 p<0.01$

Omdat zowel het gebruik van informele zorg als de opnamewens samenhingen met verschillende variabelen die ook onderling gerelateerd waren, zijn tot slot twee stapsgewijze lineaire regressieanalyses uitgevoerd. In de regressieanalyse met het gebruik van informele zorg als afhankelijke variabele werden het gebruik van professionele zorg, de HHA-score, eenzaamheidsgevoelens en depressieve klachten als onafhankelijke variabelen opgenomen. Het gebruik van professionele zorg en de HHA-score werden, niet onverwacht, in de eerste 2 stappen opgenomen in de vergelijking $\left(R^{2}=\right.$ 0.11 resp. $\left.R_{\text {change }}^{2}=0.13\right)$. Daarnaast bleken alleen eenzaamheidsgevoelens nog substantieel van invloed te zijn op het gebruik van informele zorg $\left(R_{\text {toxal }}^{2}=0.32\right)$. Depressieve klachten werden als factor geabsorbeerd door de eenzaamheidsgevoelens; de samenhang ertussen is namelijk groot (Kendall's tau $=0.64$ ). In de tweede regressieanalyse met de opnamewens als afhankelijke variabele vormden de HHA-score, de gezondheidsbeleving, eenzaamheidsgevoelens en depressieve klachten de onathankelijke variabeten. Eenzaamheidsgevoelens bleken het meest van invloed op de opnamewens $\left(\mathbb{R}^{2}=0.18\right)$; verder leverden alleen de depressieve klachten, ondanks de sterke samenhang, nog een bescheiden bijdrage $\left(\mathbb{R}_{\text {total }}^{2}=\right.$ 0.22). De gezondheidsbelleving en de HHA-score hadden, wanneer gecontroleerd werd voor deze variabelen, geen invloed op de opnamewens.

\section{Vergelijking van positief geïndiceerden met verzorgingshuisbewoners}

Om na te gaan of de hulpbehoefte van de geindiceerden geringer is dan die van de verzorgingshuisbewoners zijn ter vergelijking in tabel 2 frequentieverdelingen van een aantal kenmerken van de bewoners weergegeven. Daarbij is geen onderscheid gemaakt naar de verblijfsduur omdat een nadere analyse daarvoor geen verschillen liet zien (Frederiks 1990). (In de discussie wordt hierop teruggekomen.) De mediane verblijfsduur was 3 jaar. De groepen verschilden in een aantal achtergrondkenmerken. 
De geindiceerden waren jonger en relatief vaker (nog) gehuwd. Ook de reden voor opname, cq. aanvraag verschilde. De bewoners hebben vaker lichamelijke achteruitgang als reden opgegeven dan de geïndiceerden, die vaker de combinatie gezondheid en eenzaamheid noemden. De mate van huishoudelijke invaliditeit was vergelijkbaar in beide groepen. De geîndiceerden hadden gemiddeld wel een wat lagere ADLscore dan de bewoners. Dit verschil werd vooral veroorzaakt door het vaker voorkomen van veel ADL-beperkingen bij enkele bewoners; ongeveer de helft van beide groepen had geen ADL-beperkingen. Ten aanzien van de geestelijke toestand bestonden grotere verschillen. De geïndiceerden hadden minder vaak geheugenstoornissen, maar wel vaker depressieve klachten en bovendien voelden zij zich vaker eenzaam. De gezondheid liet eveneens enige verschillen zien. De geïndiceerden oordeelden minder positief over de eigen gezondheid dan de bewoners. Ook gaven zij vaker aan een chronische aandoening of handicap te hebben. De groepen verschilden niet of nauwelijks ten aanzien van het medicijngebruik.

\section{Discussie}

\section{De hulpbehoefte en het zorggebruik}

Naar aanleiding van de resultaten in tabel 2 kan gesteld worden dat de hulpbehoefte van de geïndiceerden tamelijk groot was. De hoge mate waarin men gebruik maakte van professionele en informele zorg bij het huishouden is dan ook niet verwonderlijk. Informele zorg bij de ADL werd veell minder vaak ontvangen, alhoewel de helft van de geïndiceerden éen of meer ADL-problemen had. Mogelijk speelde het intieme karakter van de lichamelijke zorg hierbij een rol en liet men deze zorg liever over aan professionele hulpverleners. Dat slechts een derde van de geindiceerden behoefte aan (meer) hulp aangaf kan betekenen dat veelal in de behoefte voorzien werd, maar kan ook een indicatie zijn van het niet bekend zijn met allerlei vormen van hulp.

$\mathrm{Bij}$ de resultaten dient aangetekend te worden dat, ten gevolge van de selectieve uitval, de gepresenteerde cijfers over met name de geestelijke toestand een onderschatting zullen zijn. Bosma (1989) had overigens dezelfde ervaring met geindiceerden bij een onderzoek naar de geestelijke gezondheidstoestand van ouderen: ook hij meldt een uitval van $60 \%$. De gepresenteerde cijfers laten zich wat moeilijk vergelijken met ander onderzoek. Vaak zijn er andere maten voor bijvoorbeeld de hulpbehoefte gebruikt of zijn bepaalde selectiecriteria gehanteerd. Coolen (1984) hanteerde in een onderzoek naar substitutiemogelijkheden bij geindiceerden een wat andere omschrijving van ADL- en HHA-beperkingen. Ouderen bij wie de indicatiecommissie ernstige psychische stoornissen had geregistreerd werden overigens niet in het onderzoek betrokken. De percentages ouderen met ADL- en HHA-beperkingen zijn zo'n 10\% hoger respectievelijk lager dan in ons onderzoek. Mogelijk is er naast verschil in meetmethode ook sprake van reële verschillen in het voorkomen van invaliditeit.

\section{Onderlinge samenhangen}

Verschillende aspecten van de hulpbehoefte, het zorggebruik en de opnamewens bleken onderling samen te hangen. Bij geindiceerden met veel huishoudelijke beperkingen werden, in vergelijking met degenen met minder beperkingen, vaker depressieve klachten en geheugenstoornissen aangetroffen. Zij maakten ook meer gebruik van professionele en informele zorg. Bovendien beoordeelden zij hun gezondheid negatiever. Objectief gezien hebben zij meer redenen om op korte termijn naar een verzorgingshuis te willen dan degenen met minder beperkingen. Subjectief bleek het 
anders te liggen. De wens om op korte termijn opgenomen te worden hing immers met name samen met eenzaamheidsgevoelens en depressieve klachten. De belangrijke rol die de opnamewens speelt in de indicatiestelling, zoals die naar voren kwam uit de studies van van Overbeek (1983) en Coolen en van Pelt (1985), wordt hiermee bevestigd. De gezondheidsbeleving was eveneens sterker geassocieerd met eenzaamheidsgevoelenis en depressieve klachten dan met de HHA-score. Hiermee wordt duidelijk dat, alhoewel de geindiceerden zelf veelal lichamelijke achteruitgang als reden opgaven, geestelijke problematiek vaak een achterliggende reden voor de aanvraag was en mogelikk een belangrijke reden is voor de uiteindelijke opname.

\section{Vergelijking van positief geïndiceerden met verzorgingshuisbewoners}

De verwachting dat de geindiceerden minder hulpbehoevend zijn dan de bewoners werd niet bevestigd. De geïndiceerden bleken (bijna) evenveel problemen te hebben met het huishouden en de eigen verzorging als de bewoners. Ook hadden geindiceerden een minder positieve perceptie van de eigen gezondheid. Naast reële verschilen - geindiceerden gaven ook vaker aan een chronische aandoening te hebben kan het zijn dat beide groepen van verschillende referentiegroepen zijn uitgegaan: de bewoners van hun medebewoners en de geindiceerden van thuiswonende ouderen. Ook is mogelijk dat de geindiceerden hun gezondheid negatiever beoordeeld hebben varnwege de aanvraag. Ten aanzien van de geestelijke toestand bestonden grotere verschillen. Aan het minder voorkomen van geheugenstoornissen bij geindiceerden kan echter weinig betekenis worden gehecht vanwege de selectieve uitval. De verschillen in eenzaamheidsgevoelens en depressieve klachten hebben daarentegen wel betekenis: wanneer verschillen optreden in het nadeel van de geindiceerden zullen de verschillen in werkelijkheid nog groter zijn.

Samenvattend blijkt de hulpbehoefte van de geïndiceerden minstens zo groot te zijn als die van de bewoners. Het vermoeden dat een positieve indicatie pas wordt afgegeven bij een steeds grotere hulpbehoefte wordt hiermee bevestigd. Een extra argument hiervoor wordt gevormd door de bevinding dat de hulpbehoefte van de bewoners niet bleek te verschillen naar verblijfsduur. Aannemende dat de hulpbehoefto van individuele bewoners toeneemt tijdens het verblijf, duidt dit op cohort-effecten, en wel in die zin dat in de tijd ouderen met een steeds grotere hulpbehoefte zijn opgenomen (Frederiks 1990).

De vraag rijst hoe de verschillen in eenzaamheidsgevoelens en depressieve klachten tussen de geindiceerden en bewoners verklaard kunnen worden. Een mogelijke verklaring is dat de levenswerwachting van ouderen waarbij deze problemen aanwezig zijn korter is dan bij ouderen zonder deze problemen ("survival of the fittest"). In de steekproef van de bewoners zouden dan relatief meer ouderen zonder deze problemen zijn opgenomen. Een andere verklaring is de mogelijkheid dat de geindiceerden zich in meer of mindere mate in een soort crisissituatie bevinden. Een slechter wordende gezondheid en een afnemende validiteit nopen tot het zoeken naar oplossingen waarbij opname in een verzorgingshuis een mogelijkheid is. Het perspectief om de vertrouwde omgeving te moeten verlaten en de zelfstandigheid op te moeten geven kan dan zijn weerslag thebben op de geestelijke toestand. Het minder voorkomen van depressieve klachten en eenzaamheidsgevoelens bij de bewoners komt dan voort uit een goede aanpassing aan de nieuwe situatie. Deze verklaring wordt ondersteund door de resultaten van verschillende onderzoeken. Zo vond Prock al in 1969 dat ouderen die op de wachtlijst staan voor opname in een verzorgingshuis er, in vergelijking met bewoners, psychisch slechter aan toe waren, in de zin van meer angst en spanning, gevoelens van hulpeloosheid en machteloosheid, depressieve 
klachten, lage zelfwaardering en vermindering van sociale kontakten. Uit het Nijmeegse longitudinale verplaatsingsonderzoek komt naar voren dat verhuizing naar een verzorgingshuis vaak een vooruitgang in het welbevinden met zich mee blijkt te brengen. Een accepterende houding ten aanzien van afhankelijkheid blijkt daarbij doorslaggevend te zijn (Wimmers et al. 1987). De Jong-Gierveld on Kamphuis (1986) concluderen uit hun onderzoek dat opname in een verzorgingshuis woor ouderen met een duidelijke eenzaamheidsindicatie kan leiden tot een vermindering van eenzaamheidsgevoelens. Opname in een verzorgingshuis kan dus een oplossing zijn voor ouderen met geestelijke problematiek.

Toch kunnen we ons, in het kader van het substitutiebeleid, afvragen of er geen alternatieven zijn voor opname in een verzorgingshuis. De opnamewens bleek immers met name gerelateerd te zijn aan geestelijke problematiek (met uitzondering van geheugenstoornissen). Voor de geïndiceerden met weinig huishoudelijke problemen zou (aanvullende) extramurale zorg dan ook een alternatief kunnen zijn. Zeker indien ook informele zorg aanwezig is zou thuiszorg voldoende moeten zijn om in de directe hulpbehoefte te voorzien. Een voorwaarde hierbij is wel dat een effectieve aanpak gevonden wordt voor de geestelijke problematiek. Temeer omdat bij aanwezigheid daarvan minder informele zorg ontvangen werd. Of minder informele zorg een oorzaak is of dat ouderen met deze problematiek geen informele zorg willen of minder aangeboden krijgen is overigens uit dit transversale onderzoek niet op te maken. Niettemin vormt de problematiek op zich voldoende reden om naar oplossingen te zoeken. Mogelijk kunnen voorzieningen als dagopvang en huiskamerprojecten hierbij een rol spelen (Nies 1989; Nuyens 1988). Ook het regelmatig bezoeken van ouderen door beroepskrachten of vrijwilligers zou overwogen kunnen worden (Van Rossum en Frederiks 1988; Goedhart et al. 1989).

Extramurale zorg lijkt echter alleen mogelijk voor de genoemde groep. Voor de geïndiceerden met veel huishoudelijke problemen is, gezien hun hulpbehoefte, het verzorgingshuis de aangewezen voorziening. 


\section{Literatuur}

Bisscheroux PFLA, Frederiks CMA. Ouderen en het gebruik van professionele zorg; een vergelijking van kenmerken van thuiswonende ouderen en bewoners van verzorgingstehuizen in Geleen. Maastricht, Rijksuniversiteit Limburg 1986.

Bosma A. De geestelijke gezondheidstoestand van ouderen. Opzet en voorlopige resultaten van een veldonderzoek. In: Schroots JJF, Burma A, Braum GAA, Groeneveld A, Ringoir DJB, Tempelman CJJ (red). Gezond zijn is ouder worden. Assen/Maastricht, van Gorcum 1989.

Coolen JAI, Pelt JA van. Beheersing van een voorziening via het beslissen over hulpvragen. Onderzoek naar de indicatiestelling voor het verzorgingstehuis. Tijdschrift voor Gerontologie en Geriatrie 1985; 16: 97-105.

Coolen JAl. Mogelijke substitutie tussen intramurale en extramurale zorg. Een verkenning vanuit een behoeftenbenadering. Tildschrift voor Gerontologie en Geriatrie 1984; 15: $115-125$.

Frederiks CMA. Zorgbehoefte van en zorgverlening aan ouderen. Proefschrift Rijksuniversiteit Limburg, Maastricht 1990.

Frederiks $C$, Hamers J, Wierik $M$ te. De validiteit van verzorgingstehuisbewoners. Maastricht, Rijksuniversiteit Limburg, Vakgroep Epidemiologie/GZO 1988.

Goedhart ML, Hooren van THM, Smals LMM, Wimmers MFGH. Thuiszorg bij positief geïndiceerden: een oriëntatie op alternatieven voor het verzorgingshuis. Nijmegen, Katholieke Universiteit, Intervakgroep Sociale Gerontologie 1989.

Huijsman R. Twintig jaar statistiek bejaardenoorden. Een historische analyse. Tijdschrift voor Gerontologie en Geriatrie 1988; 19: 39-47.

Jong-Gierveld $\mathrm{J}$ de, Kamphuis $\mathrm{F}$. Opname in een verzorgingstehuis; een oplossing voor eenzame ouderen? Tijdschrift voor Gerontologie en Geriatrie 1986; 17: 147-157.

Loveren-Huyben CMS van, Toonen RM, Bom JA van der. Het verzorgingstehuis: een bron van toenemende zorg (2). Gedragsbeoordeling over twee-en-een-half jaar. Tijdschrift voor Gerontologie en Geriatrie 1985; 16: 135-140.

Ministerie van WVC. Zorg voor ouderen. Den Haag, Staatsuitgeverij 1986.

Ministerie van WVC. Financieel Overzicht Zorg 1990. Den Haag. Staatsuitgeverij 1989.

Mootz M, Timmermans J, Schoemakers-Salkinoja J, Hessing-Wayner J. Samenhang in de zorg. Substitutiemogelijkheden op een viertal terreinen. Rijswijk, Sociaal en Cultureel Planbureau 1986.

Nies HLGR. Dagopvang en dagverzorging voor ouderen: nieuwe voorzieningen in ontwikkeling. Tijdschrift voor Gerontologie en Geriatrie 1989; 20: 67-72. 
Nuijens MJM. Sociale dagopvang voor ouderen. Een nieuwe schakel in het stelsel van voorzieningen in Arnhem? Tijdschrift voor Gerontologie en Geriatrie 1988; 19: 193-199.

Overbeek $\mathrm{HJ}$ van. Opneming verzocht; een onderzoek naar het indicatiesysteem van het besluit Opneming in bejaardenoorden. Den Haag, Nimawo 1983.

Prock VN. Effects of institutionalization: a comparison of community waiting list, and institutionalized aged persons. American Journal of Public Health 1969; 59 : 18371844.

Qureshi KN, Hodkinson HM. Evaluation of a ten-question mental test in the institutionalized elderly. Age and Ageing 1974; 3: 152-157.

Rossum HJL van, Frederiks CMA. Heeft preventief ouderenbezoek door wijkverpleegkundigen zin? Tijdschrift voor Gerontologie en Geriatrie 1988; 19: 3-6.

Wimmmers MFHG, Buijssen HPJ, Mertens GHM. Welbevinden van ouderen na verhuizing. Gegevens van een longitudinaal onderzoek. Nederlands Tijdschrift voor Psychologie 1987; 42: 36-44.

Zung WWK. A self rating depression scale. Archives of General Psychiatry 1965; 12: 63-70.

Zweens-ten Kate JB. Het effect van de Indicatiecommissie ex art. 6j van de Wet op de Bejaardenoorden. Tijdschrift voor Sociale Gezondheidszorg 1985; 63: 423-428. 

CHAPTER 5

INSTITUTIONALIZATION; A COMPARISON OF APPLICANTS TO NURSING HOMES AND HOMES FOR THE AGED*

Margreet JM te Wierik, Carla MA Frederiks, F Sturmans, APh Visser 


\section{Summary}

In order to irvestigate which factors, besides physical limitations, contribute to the utitization of nursing homes, a study was conducted in Maastricht among 248 elderly people. Characteristics of 113 nursing home applicants, 47 of whom were living at home and 66 of whom were in hospital, were compared with those of 135 applicants to homes for the aged. Stepwise discriminant analyses allowed a clear distinction bewwen the groups of applicants: $91 \%$ of the applicants were correctly classified. Next to functional status, the informal care index, household composition, number of visits received and use of professional home care were important discriminating characteristics. Apart from their greater need, the nursing thome applicants, especially thosie living at home, had a well-functioning social network and commonly received help from professional caregivers, whereas the applicants to homes for the aged were much worse off in these respects. The assumption that elderly people move along a care-continuum, in which the present use of professional care is determined by characteristics like the social network and previous use of care, given their need, thus seems to hold for applicants to homes for the aged but not for nursing home applicants. For the latter, this mechanism is apparently overruled by the functional status resulting from their medical condition. The findings imply that alternatives to institutional care will be more successful for applicants to homes for the aged than for nursing home applicants.

\section{Samenvatting}

\section{Institutionalisering; een vergelijking van verpleeghuisaanvragers met verzorgingshuisaanvragers}

Om na te gaan welke factoren, naast de mate van invaliditeit, bijdragen aan het gebruik van verpleeghuizen is een onderzoek uitgevoerd bij 248 ouderen in Maas. tricht. Met behulp van stapsgewijze discriminant-analyses zijn kenmerken van 113 verpleeghuisaanvragers ( 47 thuiswonenden en 66 aanvragers die in een ziekenhuis verbleven) vergeleken met 135 verzorgingshuisaanvragers. De groepen aanvragers konden op basis van de discriminant-analyses goed onderscheiden worden: $91 \%$ van de aanvragers werd in de goede groep ingedeeld. De hulpbehoefte, de informele zorg-score, de samenstelling van het huishouden, het ontvangen bezoek en het gebruik van professionele thuiszorg waren bellangrijke discriminerende variabelen. Naast hun grotere hulpbehoefte bleken de verpleeghuisaanvragers, vocral de thuiswonenden, een beter functionerend sociaal netwerk te hebben en veel vaker professionele zorg te gebruiken dan de verzorgingshuisaanvragers. De veronderstelling dat het zorggebruik van ouderen, op het continuüm van zelfzorg en informele zorg aan de ene kant en gespecialiseerde institutionele zorg aan de andere kant, gegeven de hulpbehoefte, bepaald wordt door kenmerken als het sociale netwerk en het eerdere gebruik van zorg lijkt dus wel op te gaan voor verzorgingshuisaanvragers, maar niet voor verpleeghuisaanvragers. Blijkbaar wordt dit mechanisme bij verpleeghuisaanvragers 'overrulled' door hun hulpbehoefte. De bevindingen impliceren dat alternatieven voor institutionele zorg meer succesvol zullen zijn bij verzorgingshuisaanvragers dan bij verpleeghuisaanvragers. 


\section{Introduction}

In the sixties and seventies, various studies in the Netherlands showed that elderly people applying for institutional care had a wide range of physical limitations, from relatively few to many. At the same time it was found that many elderly people living at home had a comparable number of physical limitations, without having applied for institutional care (Fennis 1973; De Amsterdamse bejaarden 1977). This not only meant that impaired elderly people living at home found ways to solve their problems to such a degree that they could stay in their own homes, but also that some of the elderly people who would like to apply for institutional care were physically too fit to justify the application. Studies in other countries had similar findings (see for instance George and Maddox 1989; Ikegami 1982). Apparently, physical limitations or functional impairment are by themselves, not sufficient explanations for differences in the utilization of institutional care by elderly people; other reasons must play an important role in the decision to apply for institutional care. Knowledge of these reasons is important for policy purposes. First of all, there is the planning of services: it might be investigated what the actual demand for institutional care is, judging on the basis of functional impairment and related factors. Next, admission criteria might be elaborated more explicitly, once there is consensus on the appropriateness of the reasons.

Finally, it could be investigated to what extent these other factors are causally related to the demand for institutional care. If causal factors appear changeabie, it could be studied to what extent interventions on these factors can decrease the demand for institutional care.

In Maastricht, a town in the south of the Netherlands (116.000 inhabitants), a study was performed to gain insight into factors, besides physical limitations, that make elderly people use professional care. In this paper, nursing home applicants are compared with applicants to homes for the aged, in order to answer the question which factors can be identified, besides physical limitations, as leading to nursing home admission.

\section{Previous research}

Determinants of the utilization of nursing homes or institutional care have been investigated by various researchers. A clirect comparison of the results of these studies is, however, not feasible, since the study designs (longitudinal and cross-sectional), the length of follow-up the care settings (nursing homes - both intermediate care and skilled nursing facilities - and chronic disease hospitals), the study populations, the variables included in the studies, the health care systems (policy, program, and financing) as well as the methods of analysis have differed greatly.

Anderson (1975) developed a behavioral model which incorporates a range of variables. Although the model was originally developed to gain insight into medical services utilization, it has been used by others to explain the utilization of health and social services by elderly people (Coulton and Frost 1982; Evashwick et al. 1984; Wan and Odell 1981; Branch 1981). The model suggests that the use of services depends on the predisposition of the individual to use services (predisposing variables), his ability to secure services (enabling variables) and his need for services (need variables). The predisposing component comprises individual characteristics which exist prior to the onset of specific episodes of illness. These characteristics include demagraphic; social structural and attitudinal-belief variables. The enabling component comprises those conditions which permit an individual to act on a value or satisfy a felt need regarding health service use. They include financial means, the nature and accessibili- 
ty of health care, as well as characteristics of the community or region. The need component is the stimulus or most direct reason for health service use, thus including different aspects of health. The model allows for a variety of characteristics with different impact in time on the utilization of services. The findings of previous research have been summarized in table 1 on the basis of this model. Only factors which were found to be associated with nursing home utilization or institutionalization in multivarlate analyses have been included.

Table 1. Studies by varioug authons and the facters they mention as related to the utifization of nursing thomes or institutional sare by olderly people

\section{AUTHOPS (yr) DESCAIPTION OF THE STUDIES}

Branch (\& Jette) (82/84) Prespective cohont study over 6 yearis on determinants of antering a nunsimg home or chronio dizease hospital among non-institutionalized elderly people

Cohen al. $(06)$

Cohen wit al. (B8)

Dasilland (65)

Evaushwigk of al (B)

Prospactive cohort sudy ower 1 year on predictors of nursing home entry among Madicare recipients living in the community

Retrospective study over varying periods of time on predictors of nursing home entry among resildents of Continuing Care Fetirement Commurities

Cross-swational study on factors relatied to the use of institutional and home care servicos among elderly residents $(70+j)$ of a small town municipality

Prospective cohort study over 15 months on detorminants of the use of a. 0 . nursing homes among elderly people living in the community

GHeonbarg \& Ginm (79) Cross-sectional study on predictors of institutionaliziation among "new" users (60) of skillod mursing homee and inthome care

Hadrick of all. (e9)

Mota-analysis of 13 (quasi) experimental studies on the effect of home care an w.o. nursing home placements

Krnopmain at al $(88)$

MeCoy Edwards $(8 \|)$

Prospective study over at lesst 2 y ars on determinants of institutionalization among outpatients with primary degenerative dementia attending a dementia clinic

Morris of al. $(87)$

One year prospoctive study on predictors of institutionaliztition among elderly persons with oldage assistanco

One year prospective stucly on the impact of different hausing and castomaneged home care programe on the wse of a.o. nurising homes and chronle thous pitalis among 5 samples of alderly poople, stratifiod by 4 comsitructed institutional risk categoriens

Morris of al. 186?

Dewolopment of a risk classfication system to predict entering a nursing home of chronils disease hospital, based on prospective cohort study over 2 and 4 years among community-residing widerlly

Fioos ot al. (eB)

Shapiro Tato (85)

Shapiro, T Tale (89)

Two-yoar followw study on predictors of a.o. nursing home entry among oldarly people liwing in the community with full coverage in the health-insurance system

Prospective cohort study over 2,5 and 7 yours om predictors of long term are facility use among alderly people living in the community

Comparison of the characteristics of 2 elderfy cohorts, their wse of a.0. nursing hames over 6,5 years, and the supply of care

Smyer (Bo)

Wiconter wall. (79)

Cross-sectional comparison of characteristics of elderly" patients, matched on $A D L$, residing in intermediate care facilities or receiving home care Fletrospective study over 10 yoars on determinants of nursing home utilization among elderly
decedents

Wan \& Odill (8)

Woissert \& Crady (89)

Cross-sectional study among eiderly community residents on determinants of a.a. institutionalization in the year prior to the study

Cross-sactional study among alderly community and nursing home residents on predictors of imstitutitional residencyt 


\section{PREDISPOSING}

\section{AGE}

Branch (12 vitie) (82/84)

Cohen of al. (B8)

colhen of al. (88)

Drattand (83)i

McCoy \& Edwards (81)

Morris ot al. (88)

Foos et al. (88)

Shapiro Tate (65)

Vicente ot al. (79)

Weissert \& Cready (89)

GENDER

Cohen al. (EB)

Greenberg \& Ginn (79)

Morris of all. (88)

Roos of al. (88)

Shapiro Tate (85)

MAFITAL STATUS

Cohen ot all. (86)

Cohen et al. (68)

Daatland (83)

Groenberg S Ginn (79)

Wicente at. (79)

Weissert \& Creadly (89)

SOCIAL SUIPPORT

Desatlend (83)

Gremberg Ginn (79)

MeCoy Edwards (B)

Morris of al. (88)

Shapiro \& Tate (D5)

Smyer (80)

MENTAL STATUS

Branch (\& Jathe) (82/84)

Shapiro Tale (85)

Simyer (Bar

Knopman ot a) (88)

Morris al (B8)

Weissert Craady (89) HOUSEHOLD COMPOSTION

Branch (8 Jettel) (82/84)

Cohen at al. (28)

MoCoy \& Edwards (B1)
Aged 80 year or older is a risk factor

Age-related probability increased an increasing rate

Older entrants in CCFC's had a greater rellative trisk

Age had the greatest impact on the use of services; the affect was strorger in town than im more rural areas

Age was asely associated with higher probabilities

Advanced age comtributed to high risk status

Higher age was a nisk factor

in the sthort and long torm, advanced age was a risk factor

Age was the best predictor

Higher age was risk factor

Males were more likely to enter risursing home

Wornen were more likely to enter a nursing horne

Being fomale contributad to high risk status

Fomales were more likely to anter a nursing hom

In the long term, boing female was a risik factor

Being widowed was positively related to nursing home entry; the impact of never being married increased with age

Being married decreased the likellihoad

Marriage was a stronger protection for older men $(80+)$ than for older women

Married persons were less likely to onter a nursing home

Unmarned persons had a higher risk

Lack of a spowse increased the risk

Aged persans in more rural areas with newby delughters ware institutionalized lass oftery in urbar ares thate was no such affoct

Fieceituing help from family decreased the risk

Persons with frequent contacts with friencs or rolatives were leas likely to be institutionalized Absence of chilledren nearby contributed to high risk status

In the long torm, having relatively frequent contacte with "olatives was a prectictor

The intitutionalized group was more likely to have had less soctal support awailablo in the community and to be more impaired in the area of social resources

Increased risk for montally disoriented elderly, aspecially when living with other people In the sthort and long term, memtal impairment was a risk factor

The institutionalized group was mone likely to be impained in the area of mental health

Patientsi with advanced dementia had a higher risk, which increased when distuptive behavior was present

Prasence of mental/amotional probleme and memory disturbancos contributed to thigh rish status

Among diagnoses, presence of mentat disorder was the most important factor 


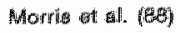 \\ Arow of 0 (8) \\ Shapiro T Tate (8)

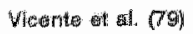

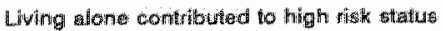

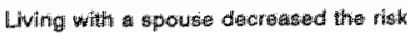

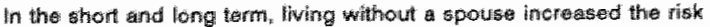 \\ LWing along wise a fhis factor
}

motsmo

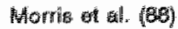

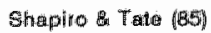

\section{ENAELINO}

FHNANOLAL MEALES

Dohom at as

Evasthwitok of al. (79)

Grombarg Ginn (79)

Morrigs at all. $(108)$

Vieente al. rog

Weisent \& Cready (89)

Living in adapted or public houbing comthbutad to high risk atatus

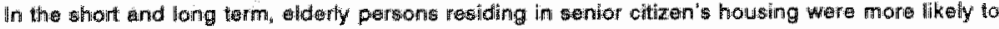
bo iristitutionatred

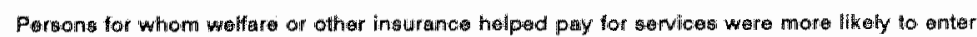

Piersone with higher incomes had a greater rigk

Persons with higher incomes had greater risk

Higher incomb contributed to high risk stetus

Personis with inadequate or marginal incomes wero more likely to stity in nursing home for 6 months or lomger

Living below the poverty line increased the risk

\section{COMMUNATY OF RESIDENCE}

Cohen al. (\$8)

The effoct of indiwidual commurities was the most important explanatory variable

Datalland (a)

Town dwellers used mare sorvices than the agod from moro rural areas

MoCoy E Edwatds (81)

Residence in oconomically depressud arows was associated with lower probability

Woisant \& Cready (89) bed

\section{USE OF PFOFESSIONAL HOME CARE}

Branch \& Jatte (82)

Hewedirick ot al. (89)

MeCoy E Edwards (81)

Morris ot al. (87)

Shapiro \& Tate (89)

Smy (60)

NEE

IN GENEAAL

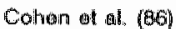

Luvalumylok at at. (84)

Mcooy Edhardos (8)

Vievarite of al. (79)

Wan \& Odall (81)

Woisen Croady (89) A.DL

Branch: (8-4)

Evmatiwitk of all 79

Grember Ginn (79)

Kinopman of al. (a)

Motiris al. (Bg)

Foes at al. (183)

Shapliro \& Tate (85)
Infrequent use of health services was related to institutionalization in a full logistic model but mot in * stepwise one

Home care seemed to have small beneficial effect

Those recelving formal services had a higher probability

Only for elderly persons with high risk stutus: those meceiving casemanaged home care in elderly persons's or carrgrengate housing oxperienced fiewer days of rusising hom placement

A decreased rate of nursing home admission was associated with an increase in home care

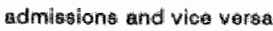

The institutlonalized group was mone likely to have had previous contact with other service providors

The moro sovere the functlonal disability the groater the likelineod

The "rieedy" usod more nursing home services

Solf-care abillty was the single most powerful predictor

Chronic conditions and phyical disability increased the rilsk of staying in a mursing home for 6 months or thore

Disebility statud was the only significant pradictor

The likelihood of institutional residancy incroesed with the severty of functional dependency

UGing assistanco in ADL incrased the risk

The more ADL limitations; the greater the risk

ADL limitations wore a risk factor

The more ADL problons, the higher the risk

Dependencies in ADL contributed to high risk status

One or moro bis disabilitios increased the risk

In the shont and long term. ADL. limitations were a eisk factor 
Hot
Branch ( Jette) (82/84)
Using assistence in thDL intreastad the risk, espocially for ofder respondents
Morris tal. (88)
Dependercies in IADL contributend to high risk status.

MEDICAL PROBLEMS

Evastwick eit (84)

Morris at. (88)

The move medical problems, the more likely to enter

Presence of cancer or stroke/fneurological conditions and history of falling contributed to high risk status

PERCEIVED HEALTH STATUS

Cohon ol al. (86)

Those assessing their health as worsening were more hikely to enter

Evashwick at al. (84)

A. poor self-percolved heath was a risk tactor

Shapiro \& Tate (B5)

In the long term, lower selfirated health was an risk factor

The overview of the literature shows that the various need characteristics have been found most consistently to contribute to the utilization of institutional care. The findings on enabling characteristics are the least consistent. The use of professional home care prior to the admission is considered as an enabling factor in this study, though this is debatable. The reason for including it here is that the use of professional home care commonly occurs after the onset of disability. Furthermore, for disabled elderly persons, professional home care can be seen as a condition for living in the community at all, giving them a choice in using institutional care. Among the predisposing characteristics, the findings regarding age, marital status, mental status and household composition are again consistent. On the face of it, these factors appear so much a matter of course that it seems trivial to study them, but it should be stressed that these very plausible factors are sometimes not identified as contributing. This might be due to the fact that they simply were not included, but also to the fact that they are too closely related, for instance household composition and marital status. In this case plausible factors may absorb one another, leading to inconsistent results. Both explanations might be true for the findings regarding gender, social support and housing.

The present study differs from previous research in the following respects. First, since the objective was to identify factors - besides physical limitations - leading to nursing home admission, it was necessary to study groups with comparable levels of physical limitations. Since applicants to homes for the aged were most likely to be comparable in this respect with nursing home applicants (Remmen 1985), they were chosen as the comparison group. Furthermore, the study took place among applicants, which avoided the problem that characteristics might have changed between the time of inventory and that of utilization, as might occur in some longitudinal studies and in studies among residents. Finally, the present study explicitly took the use of informal as well as professional home care into account.

\section{Methods}

A cross-sectional design was chosen in which elderly (55 years and over) nursing home applicants were compared with applicants to homes for the aged. The study among the applicants took place in Maastricht during the period of November 1986 to July 1988. Social workers on special committees which decide whether applications for admission to nursing homes and homes for the aged justify admission, forwarded names of applicants to the research team. Though it had been decided to exclude only nursing home applicants in need of terminal care, the committees were sometimes reluctant to forward applicants in poor mental state or with complex home situa- 
tions. Therefore, these applicants are underrepresented in the study population. Nevertheless, comparison with national figures shows that the nursing home applicants were at least as disabled as recently admitted nursing home patients in general (Te Wierik et al. 1991). The care needs of the applicants to homes for the aged were at least as great as those of a random sample of inhabitants of homes for the aged in Maastricht (Te Wierik and Frederiks 1990). This comparability regarding the disability of both groups of applicants as such is reassuring for the generalizability of our findings. In all, 157 nursing home applicants and 135 applicants to homes for the aged were interviewed. Part of the nursing home applicants (44) resided in a home for the aged. For these applicants a numer of variables (e.g. the use of informal and professional home care) are not relevant (anymore) which is inherent in residing in the home. Therefore, these applicants were excluded from the following analyses. Thus, the results apply to elderly applicants living in the community.

The interviews with either the applicants themselves or a proxy were completed by trained interviewers. The structured interviews contained, among other things, questions about the different characteristics presented in table 2. The table also provides information about operationalizations and, where applicable, technical information on scales used. In cases where nursing home applicants were staying in a hospital or other health care facility, the questions on visits received and paid, household composition, living conditions and use of professional home care were asked with regard to the period before these stays. The remaining questions on demographic

Tablo 2. The rosearch variables and the ir operationalizations

\section{CHARACTERISTIO OPERATIONALIZATION}

PAEOISPOSING
Age
Gander

Marital status

Siocial network: Informal care indax

Visitt recolvad

Vis:astes paid

Housahold

composition

Living conditions

ENABLINO

Socio-aconomic status:

Education

Finarincial means

Use of professional hom care

NEED

Functional sitatus

Age in years

Evidarti is shared in the lasit the months
Married ws not married (anymore)

The number of 9 household activitus (HHA) and $6 \mathrm{ADL}$ actiwities one ls bolng assisted with by partrer, rellatives, neighbours, trle nde of pivatoly hired ithelp (so by poople not belonging to a protossicnal care organization)

The rumber of visits the elderly person retelved per month

The number of with the elderly person peid per month

Persons belong to one housiohold when Iwing and ating

1.6 (part ofl the house to be reached vila stairs

Typo of formal schooling

Perceived sulfieitency of tinancial means

Raceiving assistance from a public thealth nurse in the performance of $\mathrm{ADL}$ and/or from the home care organization
EXPLANIATION

(range and Crombach's a)

Evident

Evident

Evident

Q-15: the higher, the more assistance: $a=0.89$

Evident

Evident

Living atone ws liwing with others

With ws. without sitairs

Primary onlly ws. more than primary schooil

Sufficient wo not sifficiont

No usie; use of one form of care and use of both forms 
variables, informal care, education, financial means, and functional status reflected the present situation.

The ADL part of the HHA-ADL scale inquired after the independent performance of rising from the bed, washing. getting dressed, using a normal tollet, feeding, and transferring within the house. Thus, this part of the scale resembles that of Katz and Akpom (1976). The part of the scale dealing with Household Activities (HHA) included questions on the independent performance of cooking, making sandwiches, dusting and washing dishes, mopping and washing windows, taking care of the heating system in the house, shopping, laundering, making the beds, and performing simple administrative tasks like paying bills. The combined scale was used since an almost identical scale, containing $5 \mathrm{ADL}$ and $7 \mathrm{HHA}$ items, when applied to elderly people living at home, had shown satisfactory Guttman coefficients and seemed to measure one concept on a wider range than either of the two component scales could do (Frederiks et al. 1991).

Since proxies had to be used for a majority of the nursing home applicants, information on the mental status of the applicants was only partly available. Therefore, this characteristic was left out of the analyses.

The data were analyzed in two ways. A bivariate analysis was performed to inventory the associations of individual characteristics with nursing home admission. In addition, stepwise discriminant analyses (using BMDP) were executed in order to identify the combinations of characteristics which best discriminated between the groups of applicants.

\section{Results}

\section{Bivariate analysis}

In table 3 the frequencies of the inventoried characteristics are presented for the different groups of applicants. The distinction between nursing home applicants coming from their own homes and those coming from hospitals is made because some questions applied to different periods for these groups. Furthermore, applicants at home are more likely to have gradually deteriorated due to chronic conditions, while those in hospital are more likely to suffer from acute conditions like fractures and strokes, or from fairly sudden worsening of chronic conditions. Table 3 shows that among the predisposing characteristics there are some clear differences between the groups of applicants, although gender, marital status, and living conditions did not differ.

The applicants to homes for the aged were found to be the oldest and the nursing home applicants in hospitals the youngest, their mean ages being 81,9 and 78,3 years respectively. The nursing home applicants at home received most informal care. Those in hospital had least informal care, which is to some extent inherent in their hospital stay, as the necessary care is provided by the staff. Applicants to homes for the aged were visited less often than nursing home applicants, irrespective of where they were coming from. The number of visits paid showed a different picture. The majority of nursing home applicants living at home did not visit anybody (anymore) before the admission, whille applicants to homes for the aged paid about the same number of visits to others as nursing home applicants in hospital did prior to their hospital stay. The applicants to homes for the aged mostly lived alone whereas $70 \%$ of the nursing home applicants at home were living with others. The fact that the 
same percentage was not married (anymore) implies that a rather large percentage of the latter lived with family or friends.

Among the enabling variables, only the use of professional home care differed. Nursing home applicants at thome more often used one or both forms of professional home care than did both the applicants to homes for the aged and the nursing home applicants in hospital, prior to their hospital stay. Finally, as far as need is concerned, the difference is obvious. Notwithstanding our attempt to include groups with a comparable level of physical limitations, the applicants to homes for the aged had far fewer limitations than the nursing home applicants at home or in hospital, the mean HHA-ADL scores being 5.8, 11.7, and 12.9 respectively.

Table 3. Charactoriatice of applicants to nutring homes and homes for the aged $(\%)(n=248$, missing data omitted)

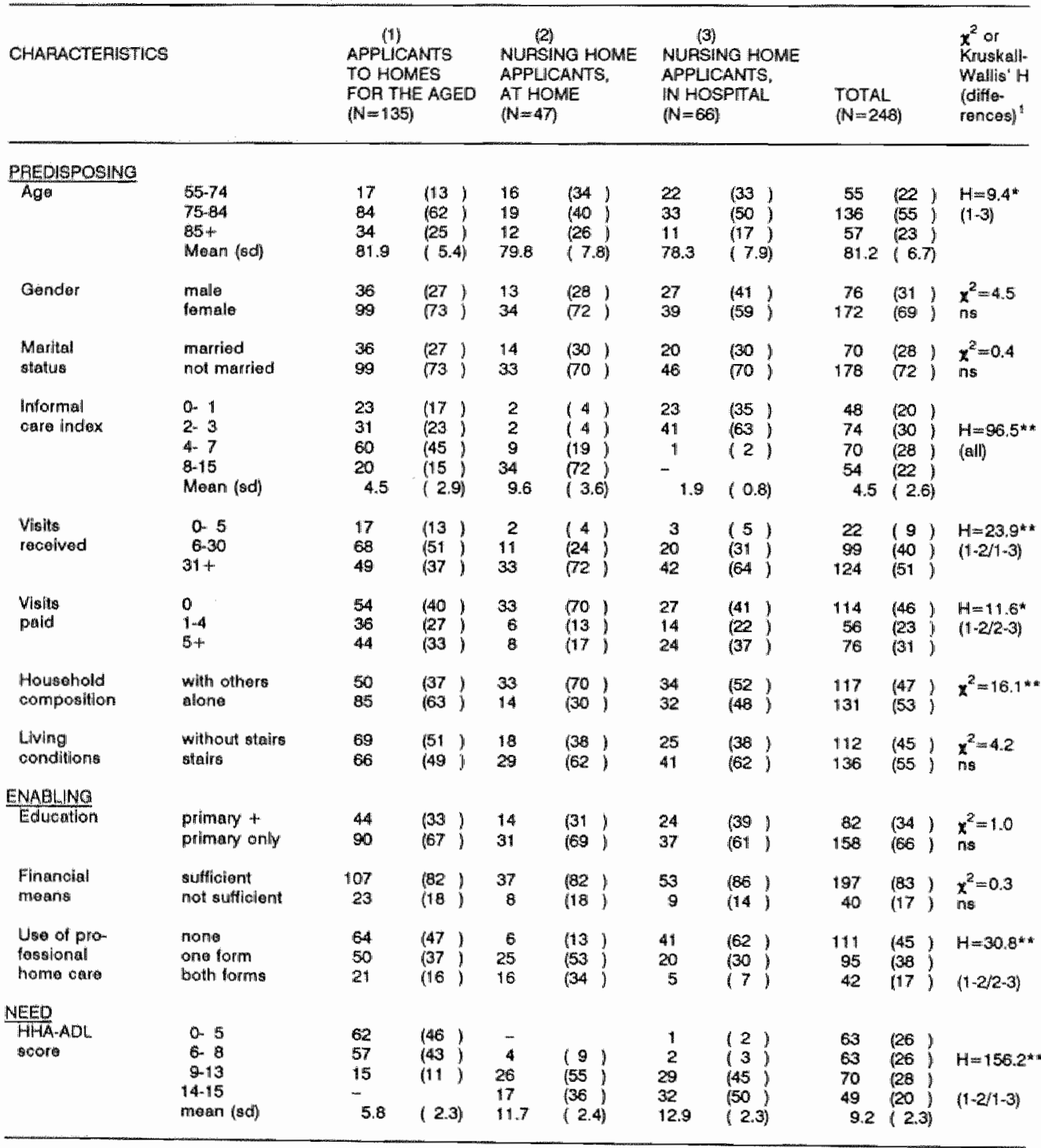

11 "per.01: * p<0.001; ne: not significant: differences: indicate differences between the three groups of applicants 


\section{Discriminant analysis}

The bivariate analysis showed that several of the inventoried characteristics differed for the various groups of applicants. To identify more precisely the influence of factors on nursing home admission a multivariate analysis which controls for interrelatedness among the characteristics is indicated. However, a complementary study, in which elderly people living at home with and without professional home care were compared, revealed that explanatory analysis (viz. logistic regression analysis) did not produce results that were satisfactory, either for practical purposes or for theoretical clarification (Frederiks 1990). So, instead of a regression analysis, stepwise discriminant analyses were performed. This analysis selects and weights variables in such a manner that differences between groups are maximized, relative to differences within groups. In this way, characteristics of applicants are discovered that have a diagnostic value for the type of care which is applied for.

Analyses were performed for the three groups of applicants simultaneously and for the three possible pairs of groups of applicants, including all inventoried characteristics. The results of these analyses are summarized in table 4 , which presents for each comparison the percentage of correct (jackknifed) classifications, the prior probability (based on group size), and the percentage of improvement. A jackknifed classification omits the data of a case when that particular case is assigned to a group. It therefore gives a more realistic estimate of the ability of predictors to separate groups. Underneath each analysis the discriminating characteristics are shown by order of entry.

Table 4. Results of the discriminant analyses $(n=223$, missing data omitted)

$\begin{array}{lll}\text { Jackknifed } & \text { Prior } & \text { Percentage } \\ \text { classification (\%) } & \text { probability }(\%) & \text { Improvement }\end{array}$

Applicants to homes for the aged

Nursing home applicants, at home

$\begin{array}{lll}93 & 54 & 39 \\ 81 & 19 & 62 \\ 94 & 27 & 67 \\ 91 & 41 & 50\end{array}$

Total

39

62

50

Characteristics: HHA-ADL score, informal care index, use of professionall home care, household composition, visits received

Applicants to homes for the aged 94

Nursing home applicants "at home

Total
84

91
74

26

62
20

55

29

Characteristics: HHA-ADL Score, visits received, household composition

Applicants to homes for the aged 99

Nursing home applicants, in hospital 93

Total
67

33

57
32

60

40

Characteristics: HHA-ADL score, informal care index, use of professional home care, household composition, visits received, financial means

Nursing home applicanlls, at home Nursing home appliciants, in hospital Totall
42

58

51

Characteristics: informal care index, HHA-ADL score, use of professionall home care, age 
The groups of applicants could be distinguished quite clearly: the percentage of correct classifications ranges from 91 to $97 \%$. Though the discrimination was strongest between applicants to homes for the aged and nursing home applicants living at home and bewween the two groups of nursing home applicants ( $97 \%$ correct) , the classification improved most $(50 \%)$ for the simultaneous comparison of the three groups. Several characteristics discriminate in more than one comparison. The HHAADL score was present in all comparisons, while the informal care index and the use of professional home care played a role in three of them. Household composition and visits received were also important characteristics, as they were discriminating in all comparisons, except for that between the two groups of nursing home applicants. Financial means discriminated only between applicants to homes for the aged and nursing home applicants at home; age only discriminated between the groups of nursing home applicants.

\section{Discussion}

The results of the discriminant analyses showed that with different combinations of the characteristics inventoried, the groups of applicants were clearly distinguishable. The characteristics which in the bivariate analysis already differed considerably between the groups of applicants, were all discriminating; additional information for two comparisons was provided only by either age or sufficiency of financiall means.

Not unexpectedly, the need variable, as measured with the HHA-ADL score, was the most important variable in this study as well. Among the predisposing variables, the informall care index, the household composition and the number of visits received were important variables. Enabling variables were less discriminating: only the use of professional home care was a predictor of group membership in more than one comparison. So far, the results are reasonably in line with the findings of other studies as presented in table 1: all discriminating characteristics have been found to be related to nursing home entry before. Looking closer however, the differences become clearer. Apart from their greater need, nursing home applicants, both at home and in hospital, more often lived with others and were visited more often. Nursing home applicants at home, moreover, received more informal as well as professional home care than applicants to homes for the aged. As was mentioned above, the low informal care index of nursing home applicants in hospital is to a large extent inherent in the hospital stay; their relatively low use of professional home care prior to the hospital stay indirectly confirms the idea that these applicants suffer from more acute conditions. This (partly) explains why these characteristics are discriminating in com-

parisons in which these applicants are included. It is somewhat more difficult to explain why these characteristics are not discriminating when nursing home applicants living at home are compared with applicants to homes for the aged. A closer look at the interrelations between these characteristics and need revealed that the correllations of the HHA-ADL score with the informal care index and the use of professional home care among these applicants were 0.69 and 0.41 respectively. Apparently, then, these characteristics are so interrelated that, when need is taken into account, these two characteristics do not provide additional information anymore.

Comparison with the results of the complementary study showed that about the same characteristics were discriminating between elderly people living at home with and without professional home care and residents of homes for the aged. In that study, the need factor was also the main discriminating characteristic, with residents being mostly in need and non-users least. Age played a more prominent role than in the present study, showing the residents to be oldest and the non-users youngest, as 
expected. However, the direction of the other relationships was again not consistent. Most informal care was received by those living at home without professional home care, who moreover most often lived with others. The number of visits received was lowest for the residents, but did not differ between the elderly with or without professional home care (Frederiks 1990). Thus, the complementary study clearly demonstrated that the both household composition and informal care, apart from the functional status, was related to the use of professional home care in the hypothesized way. The present study, however, revealed that, apart from their greater need, the nursing home applicants, especially those living at home, had a well-functioning social network and commonly received help from professional caregivers, whereas the applicants to homes for the aged were much worse off in these respects. The assumption that elderly people move along a care-continuum, in wich the present use of professional care is determined by their predisposing characteristics, like the social network, and their enabling characteristics such as the previous use of care, given their need, thus seems to hold for applicants to homes for the aged but not for nursing home applicants. Apparently, this mechanism is overruled for nursing home applicants by the functional status resulting from their medical condition. In an earlier analysis of differences between nursing home applicants coming from home or from hospital, it was found that almost half of those coming from home suffered from mental disorders, $14 \%$ had cardiovascular diseases and another $12 \%$ had cancer. The main diagnoses for those in hospital were cardiovascular diseases (41\%), mental disorders (23\%) and accident injuries (11\%) (Te Wierik et al. 1991). Hence, for the nursing home applicants living at home, it seems that their care needs have become so complex due to chronic diseases that, despite their good social network and prevalent use of professional home care, a nursing home was the only solution. The same holds true for the applicants staying in hospital, albeit that, as mentioned before, their disability is due to either acute disorders or fairly sudden deterioration of chronic diseases.

All of this leads us to conclude that the most important difference between the utilization of nursing homes and homes for the aged is given by need factors, including the medical condition, and that predisposing and enabling factors, in the end, have little impact on preventing the use of nursing homes. For applicants to homes for the aged, the impact of predisposing and enabling factors is larger. Despite the increasingly popular idea in the Netherlands that nursing homes and homes for the aged have gradually become more similar and are hard to distinguish from each other (Remmen 1985; Ministerie van WVC 1988 \& 1989), Our findings show that they still are different institutions in nature, as their applicants show more differences than similarities.

Within the framework of the present policy regarding the care for the elderly, alternatives for institutional care can be thought of more easily for applicants to homes for the aged than for nursing home applicants. Expansion of professional home care, support of the informal caregivers and offering social activities may delay the use of homes for the aged, especially for those in lower need. For nursing home applicants the prospects are less promising.

Interventions on predisposing and enabling variables, as far as these can be altered, will have little impact, as their influence on the utilization of nursing homes is small. Interventions on need factors, which as such would be most effective, are not feasible as the applicants mostly suffer from disorders which still cannot be cured and most probably will not be curable in the near future (Stuurgroep Toekomstscenario's Gezondheidszorg 1985). 
Thus, the comparison of the nursing home applicants with the applicants to homes for the aged revealed that the impact of various factors on the process of institutionalization is different for the two groups. Given the lower need of the applicants to homes for the aged, their poorer social network and lower use of professional home care, alternatives to institutional care will be much more successful for applicants to homes for the aged than for nursing home applicants. For these applicants, their high care needs, despite their well-functioning social network and use of professional home care, inevitably appear to lead to nursing home admission. 


\section{References}

De Amsterdamse bejaarden in 1976. Amsterdam, Veldkamp Marktonderzoek BV 1977.

Anderson R, Kravits J, Anderson OW (eds). Equity in health services: empirical analysis in social policy. Cambridge, Mass, Ballinger Publishing Company 1975.

Branch L, Jette A, Evashwick $C_{n}$ Polansky M, Rowe G, Diehr P. Toward understanding elders' health service utilization. Journal of Community Health 1981; $7: 80-92$.

Branch LG, Jette AM. A prospective study of long-term care institutionalization among the aged. American Journal of Public Health 1982; 72: 1373-1379.

Branch LG. Relative risk rates of nonmedical predictors of institutional care among elderly persons. Comprehensive Therapy 1984; 10: 33-40.

Cohen MA, Tell EJ, Wallack SS. Client-related risk factors of nursing home entry among elderly adults. Journal of Gerontology 1986; 41: 785-792.

Cohen MA, Tell EJ, Wallack SS. The risk factors of nursing home entry among residents of six continuing care retirement communities. Journal of Gerontology 1988; 43 : s15-s21.

Coulton C, Frost AK. Use of social and health services by the elderly. Jlournal of Health and Social Behavior 1982; 23: 330-339.

Daatland SO. Use of public services for the aged and the role of the family. The Gerontologist 1983; 23: 650-656.

Evashwick C, Rowe G, Diehr P, Branch L. Factors explaining the use of health care services by the elderly. Health Services Research 1984; 19: 357-382.

Fennis HWJM. Medische demografie voor bejaarden. Bevolking, sterfte, ziekte en invaliditeit. Leiden, NIPG, TNO 1973.

Frederiks CMA, Wierik MJM te, Visser APh, Sturmans F. A scale for the functional status of the elderly living at home. Journal of Advanced Nursing 1991; 16: 287-292.

Frederiks CMA. Zorgbehoefte van en zorgverlening aan ouderen. Proefschrift Rijksuniversiteit Limburg. Maastricht, 1990.

George LK, Maddox GL. Social and behavioral aspects of institutional care. In: Aging and health care. Social science and policy perspectives. Ory MG, Bond K (eds). Londen/New York, Routledge 1989.

Greenberg JN, Ginn A. A multivariate analysis of the predictors of long-term care placement. Home Health Care Services Quarterly 1979; 1: 75-99.

Hedrick SC, Koepsell TD, Inui T. Meta-analysis of home-care effects on mortality and nursing-home placement. Medical Care 1989; 27: 1015-1026. 
Ikegami $N$. Institutionalized and the non-institutionalized elderly. Social Science and Medicine 1982; 16:2001-2008.

Katz S, Akpom CA. A measure of primary sociobiological functions. International Journal of Health Services 1976; 6: 493-507.

Knopman DS, Kitto J, Deinard $S_{*}$ Heiring J. Longitudinal study of death and institutionalization in patients with primary degenerative dementia. Journal of the American Geriatrics Society 1988; 36: 108-112.

McCoy JL, Edwards BE. Contextual and sociodemographic antecedents of institutionalization among aged welfare recipients. Medical Care 1981; 19: 907-921.

Ministerie van WWC. Ouderenbeleid. Voortgangsrapportage 1982-1988. Den Haag, Staatsuitgeverij 1988.

Ministerie van WVC. Financieel Overzicht Zorg 1990. Den Haag, Staatsuitgeverij 1989.

Morris JN, Gutkin CE, Ruchlin HS, Sherwood S. Housing and case-managed home care programs and subsequent institutional utilization. The Gerontologist 1987; 27 : 788-796.

Morris JN, Sherwood S, Gutkin CE. Inst-Risk II: an approach to forecasting relative risk of future institutional placement. Health Services Research 1988; 23: 511-536.

Remmen JWM. Bejaardenoordbewoners of werpleeghuispatienten? Hoogezand, Stubeg 1985.

Roos NP, Roos LL, Mossey J, Havens B. Using administrative data to predict important health outcomes; entry to hospital, nursing home, and death. Medical Care 1988; 26: $221-239$.

Shapiro E, Tate RB. Predictors of long term care facility use among the elderly. Cana* dian Journal on Aging 1985; 4: 11-19.

Shapiro E, Tate RB. Is health care use changing? A comparison between physician, hospital , nursing home, and home-care use of two elderly cohorts. Medical Care $1989 ; 27: 1002-4014$.

Smyer MA. The differential usage of services by impaired elderly. Journal of Gerontology 1980; $35: 249 \cdot 255$.

Stuurgroep Toekomstscenario's Gezondheidszorg. Ouder worden in de toekomst; scenario's over gezondheid en vergrijzing, 1984-2000. Utrecht, Van Arkel 1985.

Vicente $L$, Wiley JA, Carrington RA. The risk of institutionalization before death. The Gerontologist 1979; 19:361-367.

Wan TTH, Odell BG. Factors affecting the use of social and health services among the elderly. Ageing and Society 1981; 1: 95-115. 
Weissert WG, Cready CM. Toward a model for improved targeting of aged at risk of institutionalization. Health Services Research 1989; 24: 485-510.

Wierik MJM te, Frederiks CMA. De hulpbehoefte en opnamewens van positief geïndiceerden; een vergelijking met verzorgingshuisbewoners. Tijdschrift voor Gerontologie en Geriatrie 1990; 21: 115-123.

Wierik MJM te, Frederiks CMA, Visser APh, Sturmans F. Verpleeghuisopname; een onderzoek bij op te nemen ouderen. Accepted by Tijdschrift voor Gerontologie en Geriatrie. 



\section{CHAPTER 6}

STRAIN AMONG INFORMAL CAREGIVERS OF APPLICANTS TO NURSING HOMES AND HOMES FOR THE AGED*

Margreet JM te Wierik, Carla MA Frederiks, APh Visser, F Sturmans 


\section{Summary}

Informal caregivers of applicants to nursing homes $(n=69)$ and homes for the aged $(n=46)$ were interviewed to study the strain they experienced. It was investigated whether informal caregivers of nursing home applicants experience more strain than those of the applicants to homes for the aged. Furthermore, the associations of various factors with the strain were analyzed to gain insight into the strain experienced. The results of the bivariate analysis showed that the care given by the informal caregiver, aspects of the health of the informal caregiver, the care needs of the applicant and living with the applicant were related to the strain experienced, together with the type of caregiving (whether care is given to an applicant to a nursing home or to a home for the aged). Most of these factors were interrelated as well. When considered simultaneously, only feelings of loneliness, self-rated health and the type of caregiving appeared to have an independent association with the strain experienced. Apparently, the variables were interrelated in such a way that some variables did not provide additional information on the strain experienced if the influence of other variables was controlled for. The results further revealed that informal caregivers of nursing home applicants did experience more strain than those of applicants to homes for the aged. The type of caregiving on its own explained $4 \%$ of the variance in the strain experienced. In all, $42 \%$ of the variance in the strain experienced was explained.

\section{Samenvatting}

\section{De ervaren belasting bij informele zorgverleners van verpleeg- en verzorgingshuisaanvragers}

Informele zorgverleners van verpleeghuisaanvragers $(n=69)$ en verzorgingshuisaanvragers $(n=46)$ zijn geinterviewd om de belasting die zij ervaren bij het zorgen voor de aanvragers te onderzoeken. Nagegaan werd of de informele zorgverleners van verpleeghuisaanvragers meer belasting ervaren dan die van verzorgingshuisaanvragers. Om inzicht te krijgen in de ervaren belasting werd nagegaan of, en zo ja, welke factoren samenhangen met de ervaren belasting. Bivariaat bleken de zorg die verleend werd door de informele zorgverlener, gezondheidsaspecten van de informele zorgverlener, de maten voor de hulpbehoefte van de aanvrager en het al dan niet samenwonen met de aanvrager gerelateerd te zijn met de envaren belasting, evenals de soort zorgverlening (of de zorg aan een verpleeghuisaanvrager of aan een verpleeghuisaanvrager gegeven werd). Veel van deze factoren bleken ook onderling samen te hangen. Wanneer deze factoren gelijktijdig in verband gebracht werden met de ervaren belasting, dan bleken alleen de eenzaamheidsgevoelens, de subjectieve gezondheidsbeleving en de soort zorgverlening een onafhankelijke associatie te hebben met de ervaren belasting. Blijkbaar zijn de factoren onderling dermate gecorreleerd dat de overige geen informatie meer bijdragen wanneer gecontroleerd wordt voor de invioed van andere factoren. De resultaten lieten tevens zien dat informele zorgverleners van verpleeghuisaanvragers inderdlaad meer belasting ervaren dan die van de verzorgingshuisaanvragers. De soort zorgverlening alléen verklaarde $4 \%$ van de variantie in ervaren belasting. In totaal werd $42 \%$ van de variantie in de ervaren belasting verklaard. 


\section{Introduction}

Several studies in the past two decades have revealed that social support determines to a considerable extent whether or not a person is institutionalized. Disabled elderly persons who receive social support are less likely to be institutionalized than those who receive little or no social support (Branch and Jette 1982; Brody et al. 1978; Evashwick et al. 1984; Smyer 1980). More recently, within the framework of social support, attention has been paid to the informal caregivers of disabled elderly persons (Cantor 1983; Colerick and George 1986; Lawton et al. 1989; Poulshock and Deimling 1984; Robinson and Thurnher 1979; Soldo and Myllyluoma 1983; Tobin and Kullys 1981; Worcester and Quayhagen 1983; Zarit et al. 1980). Attention is being focussed on the abilities and disabilities of these caregivers and, more specifically, on the strain they experience. These characteristics are considered to be of major impor. tance, not only because of their possible contribution to explaining institutionalization, but also because insight into these (dis)abilities and strain might help, by finding ways to support the caregivers, keep disabled elderly people at home as long as possible. This paper adresses the strain experienced by informal caregivers and factors that are related to this strain. A study was undertaken in the Netherlands on factors which could explain the differential use of social and health care services by disabled elderly people. In addition to the applicants themselves, informal caregivers of applicants to nursing homes and homes for the aged were interviewed, in order to measure, among other things, the strain they experienced. The study was conducted in Maastricht, a town of about 116.000 inhabitants in the south of the Netherlands. In this country, thomes for the aged are meant for elderly people who can no llonger take care of their own housekeeping. In the homes, they are given a small apartment. Cleaning and meals are provided and, if necessary, some ADL assistance is given. Theil own general practitioner is responsible for medical care. The residents' contribution to the costs of the stay depends on their financial means. In nursing homes, on the other hand, the emphasis is on nursing and medical care. Patients are admitted to either a somatic or a psychogeriatric ward; they receive medical care from the nursing home physician. The stay is financed by a state-organized health insurance scheme and by income-linked contributions from the patients. Applications for admission to either of these institutions should be made to special committees which decide whe ther admission is justified. The utilization of these services is relatively high. In 1987, as many as $10 \%$ of the elderly people (65 years and over) resided in these institutions: $7.5 \%$ in homes for the aged and $2.5 \%$ in nursing homes (Huijsman and Rutten 1989). It is very likely that informal caregivers of nursing home applicants experience more strain than those of applicants to homes for the aged. Not only because the care needs of nursing home applicants, in general, are greater than those of applicants to homes for the aged, but also because of different disease history and prognosis. Apart from those nursing home patients whose admittance is due to sudden diseases like strokes and fractures of the hip. the disease history of nursing home applicants is generally longer and more serious; their prognosis is worse. Furthermore, although a home for the aged and a nursing home are both commonly considered to be the final station, the image of a nursing home is much more negative. If an institution is to be entered, a home for the aged is no doubt preferred, which as such can have an impact on informal caregivers of nursing home applicants independent of the higher care needs. This paper elaborates on the question whether informal caregivers of nursing home applicants indeed experience more strain than those of applicants to homes for the aged as hypothesized above. In this study, a broad definition of informal caregivers was used, including family members as well as non-family members, 
as long as they were providing instrumental support or were engaged in organizing daily care. Taking care of an infirm elderly person can be stressful. A stressor can be defined as an event or situation that has the potential of causing strain. Therefore, strain was seen as a consequence of enduring problems in taking care of an infirm elderly person (Lawton et al. 1989). To gain insight into the strain experienced, the relationships between various factors and the strain were analyzed. These factors, which have been found earlier to be related to strain, include the amount of care provided by the informal caregiver, the care needs of the applicant, and the (physical and mental) health of the caregiver (Cantor 1983; Fengler and Goodrich 1979;

Poulshock and Deimling 1984; Robinson 1983).

\section{Methods and subjects}

The study population consisted of informal caregivers of applicants to homes for the aged and to nursing homes. Names of applicants were forwarded to the research team by the above mentioned special committees. Although it had been decided to exclude only nursing home applicants in need of terminal care, the committees were sometimes reluctant to forward names of applicants in poor mental state or with complex home situations. Therefore, these applicants are underrepresented in the study population. The participating applicants to homes for the aged were asked whether there was a main informal caregiver. If there was one, he or she was asked by phone to participate in the study. For nursing home applicants the procedure was slighty different. In the many cases where the applicants were physically or mentally unable to decide for themselves, the special committee asked the informal caregivers to participate. In all other cases the same procedure was followed as for the applicants to homes for the aged.

Informal caregivers were obviously more often present for nursing home applicants than for applicants to homes for the aged. Of the 135 applicants to homes for the aged only $46(35 \%)$ named an informal caregiver, all of whom were interviewed. By contrast, $130(80 \%)$ of the 157 nursing home applicants had such an informal caregiver, of whom 127 were interviewed. About $50 \%$ of the nursing home applicants were admitted from a hospital; admission reasons included worsening of chronic diseases or complications, as well as acute disorders like strokes or fractures of the hip. Since the care needs of these applicants are very likely to have changed with respect to the former home situation on which the interviews with the informal caregivers focussed, their caregivers $(n=58)$ were excluded from the following analyses. Thus, the results apply to the informal caregivers of those applicants to nursing homes and homes for the aged who were still living in the community.

The informal caregivers were interviewed at their own homes by trained interviewers using a structured questionnaire. This was done, as much as possible, before the actual admission took place. A major requirement in constructing the questionnaire was that the interview had to be short, as it was expected that some of the informal caregivers would have to act as informants on behalf of the applicants as well, if the latter were incapable of being interviewed themselves. The structured questionnaire was pretested for face validity by 10 informal caregivers of applicants to nursing homes and was found to be suitable. The questionnaire contained questions about background characteristics, care given by the informal caregiver and by others, the strain experienced by the informal caregiver, aspects of the physical and mental health of the informal caregiver and the care needs of the applicant. Table 1 provides the investigated concepts with their operationalizations and, where applicable, technical information on the scales used. Besides the care given by the informal caregiver, 
Table 1. The research wariables and their operationalizations

Varialle

Oparetionalization (iscores and Cronbach's a)

Background variables

Fitationship

Kind of relationship botween the informal caregiver and applicant; distinetion betweon spevae, chilldren and other relationships

Age

Ago in years

Gender

$0=$ female: 1 = male

Marital status

Distinction between being married and not married (anymorie)

Outside activities

Whether or not the intormal caregiver had outside activitien, like 近 job or courses

Children

Whether or not the intommal caregiver had children living at home

Housing

Whether or not the informal caregiver lived in the same house with the applicart; $0=$ not liwing with the applicant; $1=$ living with the applicant

Type of caregiving

Whether the informal canegilwer was taking care of an applicant to a home for the aged of of a nursing home applicint; 0 = caregiving to an applicant to a home for the aged; $1=$ caregiwing to a nursing home appliciant

\section{Care given by the informal caregiver}

ADL carto

Help during the night

\section{Care glven by others}

ADL care given by other informal caregivers

ADL care given by profesionon caregivars

\section{Sirain experienced by} the intormal caregivers

\section{Aspocts of health}

Selforated themelth

Foelings of honeliness

Care needs of the applicant

Fumctional status

Need for presence
The amount of care given by the informal caregiver for 6 ADL activities: fising from the bad: washing, getting dressed, using a tollet, feeding and transferring within the house; posslble scores per item: $0=$ no care provided; 1 in informal caragiver was one of the providere; 2 informal caregiver was the only provider; $\mathrm{ADL} I \mathrm{IC}$ score $=$ the sum of the scores for the $6 \mathrm{ADL}$ activities; range D-12: $\alpha=0.81$

The frequency of help given by the informal caregiver during the night; the scare ranged from $0=$ no hellp glven, to 2 = halp during the night was given three or more timels per week

The amount of care given by other informal caregivers (OlC) for the $6 \mathrm{ADL}$ actiwities; an $A D L$ OlC score wes computed in the same way as the ADL IC score; range $0.12 ; \alpha=0.80$

The amount of care given by profossional carogivers (PC) for the 6 ADL activittes; an $A D L, P C$ scone was computed in the same way the ADL $\| C$ score; range 0-12; $a=0.78$.

The CSI score = the sum of positive answers to the questions of a translated version of the Caregiver Strain Index (CSI, Probinson 1983); range 0-13; $\alpha=0.75$;

Subjecte were asked to rate their own health in comparison with age pers on fivo poimt scale ranging from $1=$ excellent. to $5=$ poor

A direct question after foelings of lanalimes; the sicore ranges from $0=$ mever, $10.2=$ often

$\mathrm{ADL}$ score = the number of the $6 \mathrm{ADL}$ activtties one is unable to pertom lindependently; rainge 0.6 ; $a=0.86$

A disem question after the ned for somebody to be prosant during the day; the score ranges from $0=$ not urgent, to $2=$ urgently needed all day 
for the ADL. For the ADL, a 6 item ADL scale was used, resembling the Katz ADL scale (Katz and Apkom 1976). The strain experienced by the informal caregivers was measured with a translated version of the Caregiver Strain Index (CSI "Robinson 1983), as a Dutch screening instrument was not available at the start of the study. The CSI was chosen because it intends to measure the impact on caregivers, as subjectively experienced by them, of having to care for disabled elderly persons. Furthermore, it is a short instrument and, although it was only validated for informal caregivers of recently hospitalized elderly patients, the results of Robinson's study on its usefulness were promising. Two compact indicators of health were used, as the interview had to be short. The first was self-rated health, which is known to be strongly associated with, among other things, functional status (Ferraro 1980; Linn and Linn 1980; Van Rossum et al. 1989). The second indicator was feelings of loneliness, which correlate well with, for instance, depression (Bisscheroux and Frederiks 1985; De Jong-Gierveld 1980).

The data were analyzed in two ways. Bivariate analyses were performed to inventory differences between the two groups of caregivers on the one hand and the associations between individual factors on the other. In addition, a multiple regression analysis was executed to study the associations between the strain experienced and each of the individual characteristics, while controlling for the others.

\section{Results}

In table 2 the characteristics of the informal caregivers and applicants are presented together with the CSI scores. The caregivers were mostly married, female children or daughters in law. One third were living with the applicants and one third had outside activities, usually jobs. There are some obvious differences in background characteristics between the two groups of caregivers. Among the caregivers of nursing home applicants there were more males and they more often had outside activities than the caregivers of applicants to homes for the aged. Furthermore, the caregivers of nursing home applicants provided more ADL care and help during the night than those of applicants to homes for the aged. Whereas other informal caregivers did assist in providing ADL care among nursing home applicants as well, they were absent among applicants to homes for the aged. Professional caregivers gave considerable assistance in ADL care especially among the nursing home applicants.

The informal caregivers did not differ in their feelings of loneliness or self-rated health. The differences in care needs of the applicants to the two institutions are large: about $70 \%$ of the applicants to homes for the aged were independent for the $6 \mathrm{ADL}$ activities, whereas half of the nursing home applicants were dependent for 4 or more activities of daily living. Furthermore, according to the caregivers, more than half of the nursing home applicants needed to have somebody present all day, whereas this was the case for only $17 \%$ of the applicants to homes for the aged.

The caregivers of nursing home applicants experienced significantly more strain, as reflected by the CSI scores, than those of the applicants to homes for the aged: the mean scores were 7.1 and 4.8 respectively.

To gain insight into factors that contribute to the strain experienced by the caregivers, the correlations between several clusters of variables and the CSI score were computed. The results of this analysis are shown in table 3 , which shows all possible interrelations between the variables in the analysis; they were coded as indicated in table 1. 
Table 2. Cilharacteristics of the informal caregivors and applicants

\begin{tabular}{|c|c|c|c|c|}
\hline & $\begin{array}{l}\text { Nursing } \\
\text { homes } \\
(n=68)\end{array}$ & $\begin{array}{l}\text { Homes lor } \\
\text { the agad } \\
(n=4)\end{array}$ & $\begin{array}{l}\text { Total } \\
\text { group } \\
(n=115)\end{array}$ & $\begin{array}{l}x^{2}-1 \\
\text { tost }\end{array}$ \\
\hline \multicolumn{5}{|l|}{ Informal Caregiver } \\
\hline \multicolumn{5}{|l|}{ Reilationship to applicant } \\
\hline spouse & $13 \%$ & $11 \%$ & 129 & \\
\hline athildran & $61 \%$ & $7 \mathrm{~g}$ & $68 \%$ & ns: \\
\hline other & $20 \%$ & $14 \%$ & $20 \%$ & \\
\hline Mean age $(S D)$ & $56.3(12.4)$ & $55.3(14.1)$ & $55.9(13.1)$ & $\mathrm{ns}$ \\
\hline Gender (\% fomiale) & $55 \%$ & $7,4 \%$ & $63 \times$ & $4.98^{\text {ia }}$ \\
\hline Marital status (\% married) & $83 \%$ & $76 \%$ & $80 \%$ & กs \\
\hline Chi dren living at home & $41 \%$ & $52 \%$ & $45 \%$ & ns \\
\hline Outside actiwities & $42 \%$ & $24 \%$ & $35 \%$ & $3.99^{8}$ \\
\hline Living wittin applicant & $33 \%$ & $33 \%$ & $33 \%$ & ng \\
\hline \multicolumn{5}{|l|}{ Halp during the night } \\
\hline 0 & $64 \%$ & $81 \%$ & $71 \%$ & \\
\hline 1 & $17 \%$ & $17 \%$ & $17 \%$ & $7.37^{\mathrm{a}}$ \\
\hline 2 & $19 \%$ & $2 \%$ & $12 \%$ & \\
\hline Mean ADL liC score (SD) & $2.6(3.2)$ & $0.9(2.1)$ & $1.9(2,9)$ & $3.32^{6}$ \\
\hline Mean ADL OlG score (SD) & $1.0(2.1)$ & $0.0(0.0)$ & $0.6(1.7)$ & $3.39^{13}$ \\
\hline Mean ADL PW sicore (SD) & $3.6(3.0)$ & $0.6(1.0)$ & $2.4(2.8)$ & $6.5 \pi^{\mathrm{B}}$ \\
\hline Mean self-rated health (SD) & $2.0(1.0)$ & $2.4(1.2)$ & $2.1(1.1)$ & ns \\
\hline \multicolumn{5}{|l|}{ Farellings of loneliness } \\
\hline newer & $69 \%$ & $65 \%$ & 68 & \\
\hline sometimes & $15 \%$ & $24 \%$ & $18 \%$ & ns \\
\hline often & $16 \%$ & $11 \%$ & $14 \%$ & \\
\hline Mean CSI score (SD) & $7.1(2.9)$ & $4.8:(2.5)$ & $6.2(3.0)$ & $41,34^{b}$ \\
\hline \multicolumn{5}{|l|}{ CSi scor } \\
\hline 0.4 & $19 \%$ & $52 \%$ & 329 & $1955^{\circ}$ \\
\hline $5-8$ & $43 \%$ & $39 \%$ & $42 \%$ & $18.55^{\circ}$ \\
\hline $9-13$ & $38 \%$ & $9 \%$ & 264 & \\
\hline \multicolumn{5}{|l|}{ Applicant } \\
\hline \multicolumn{5}{|l|}{ ADL sciore } \\
\hline 0 & $\begin{array}{r}4 \% \\
45 \%\end{array}$ & $\begin{array}{l}72 \% \\
28 \%\end{array}$ & $38 \%$ & $65.38^{\circ}$ \\
\hline $4-6$ & $51 \%$ & $0 \%$ & $31 \%$ & \\
\hline \multicolumn{5}{|l|}{ Maed for presence } \\
\hline not urgent & $3 \%$ & $65 \%$ & $30 \%$ & \\
\hline urgent part of the day & $32 \%$ & $17 \%$ & $26 \%$ & $48.42^{c}$ \\
\hline urgenil all dey & $65 \%$ & $17 \%$ & $44 \%$ & \\
\hline
\end{tabular}

\footnotetext{
ns: not signifigent

a: $x^{2} p<0.05$

b: $:$-test $p<0.01$

c: : $x^{2} p<0,001$
} 
Table 3. Correlation matrix", total group $(n=115)$

\begin{tabular}{|c|c|c|c|c|c|c|c|c|c|c|}
\hline & 1 & 2 & 3 & 4 & 5 & 6 & 7 & 8 & 9 & 10 \\
\hline 1 Strain & 1 & & & & & & & & & \\
\hline 2 Feelings of Ioneliness & .33 & 1 & & & & & & & & \\
\hline 3 Self-rated health & .31 & .19 & 1 & & & & & & & \\
\hline 4 Help during the night & .28 & - & - & 1 & & & & & & \\
\hline 5 Amount of care given by 10 & .39 & 。 & - & .57 & 1 & & & & & \\
\hline 6 Need for presence & .43 & - & - & .41 & .44 & 1 & & & & \\
\hline 7 ADL score & .31 & $=$ & -.19 & .32 & .40 & .47 & 1 & & & \\
\hline 8 Amount of care given by $\mathrm{OlC}$ & $\cdot$ & - & - & - & - & .35 & .35 & 1 & & \\
\hline 9 Amount of care given by $\mathrm{PC}$ & - & - & - & - & - & .21 & .57 & - & 1 & \\
\hline 10 Type of caregiving & .38 & - & - & .23 & .30 & .64 & .71 & .30 & .52 & 1 \\
\hline
\end{tabular}

1: only associations signifant at the 0.05 level (two-tailed) are presented

The strain experienced was positively associated with all variables in the analysis, except for the amount of care given by other informal caregivers and by professional caregivers. The correlation matrix further shows that, within the clusters of wariables, most variables were interrelated, and that variables of different clusters were interrelated as well. The measures of the care given by the informal caregiver (ADL care and help during the night) were positively related to the measures of the care needs of the applicants (functional status and need for presence). The measures of care given by others (ADL care given by other informal caregivers and by professional caregivers) were also associated with the measures of the care needs of the applicants. The type of caregiving was related to the measures of all clusters of variables, except for the measures of the health of the caregivers (self-rated health and feelings of loneliness).

The ADL score and the amount of ADL care given by the caregiver were rather weakly correlated. This may be explained by the fact that the caregiver was not always the only one who provided care. The amounts of care given by other informal caregivers and by professional caregivers were both related to the ADL score of the applicant as well. This indicates that the more dependent the applicant was for ADL, the more others -professional as well as informal - were involved in the caregiving process. The only background variable that was correlated with the strain was living with the applicant: these caregivers reported higher strain $(r=0.18, p<0.03)$.

Since several variables associated with the strain experienced were interrelated, a multiple linear regression analysis was performed to identify the independent contribution of each variable, while controlling for the others. In addition to the variables in the correlation matrix gender and outside activities were included in the analysis as independent variables, since they differed for the type of caregiving. Living with the applicant was included too , as it was related with the strain experienced. The standard multiple regression analysis, with strain as the dependent variable, was performed with the variables coded as indicated in table 1. Table 4 displays the standardized regression coefficients (B), their significance level, the semipartial correlations (si), $\mathrm{F}_{n} \mathrm{R}^{2}$ and adjusted $\mathrm{R}^{z}$. A semipartial correlation is the correlation of an independent variable, adjusted for the other independent variables in the analysis, with the dependent variable; the squared semipartial correlation expresses the unique contribution of that independent variable to the total variance of the dependent variable. 
Tabile 4. Results of the multiple linear regression analysis

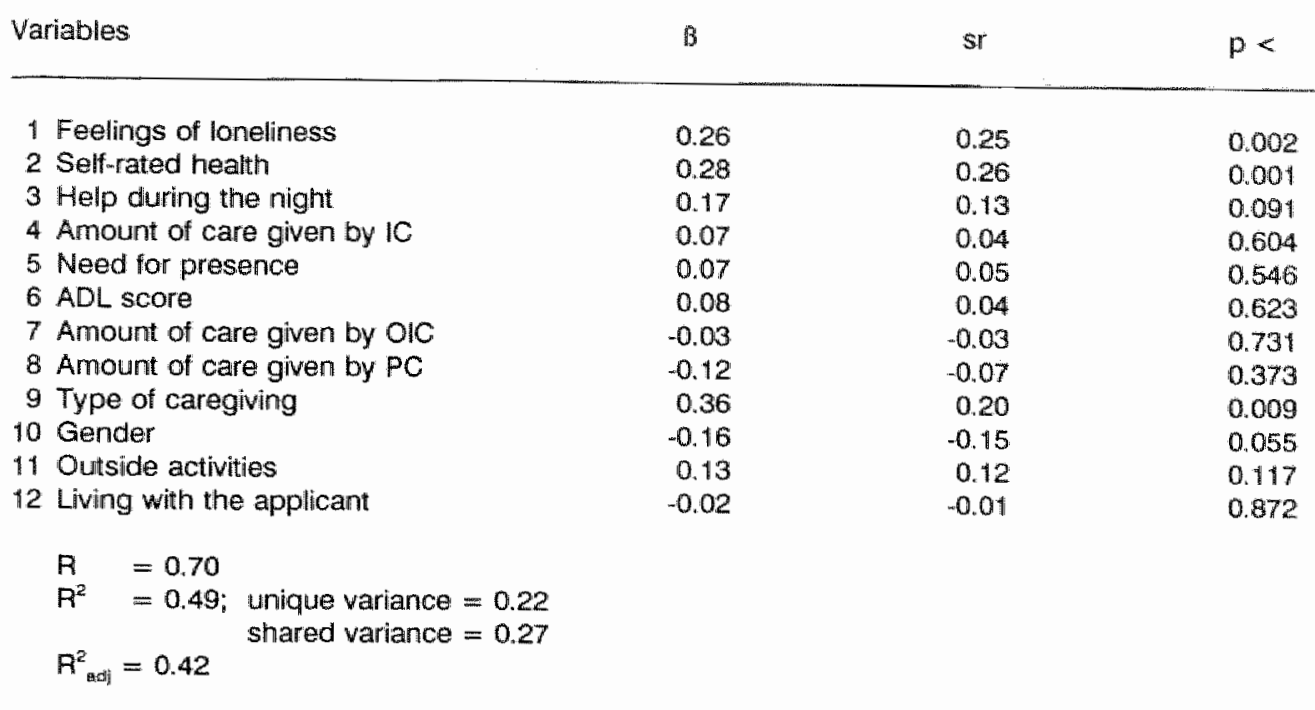

The $R$ for regression of 0.70 was significant $(F(12,92)=7.39, p<0.001)$. Only three of the independent variables were significantly associated with the strain experienced: feelings of loneliness $\left(B=0.26, \mathrm{sr}^{2}=0.06\right)$, self-rated health $\left(B=0.28, \mathrm{sr}^{2}=0.07\right)$, and type of caregiving $\left(B=0,36, s r^{2}=0.04\right)$. Gender and help during the night also seemed to be related, but these associations did not reach statistical signifance at the 0.05 level. The combined independent variables explained $49 \%$ ( $42 \%$ adjusted) of the variance in the strain experienced, $27 \%$ of which was shared variance and $22 \%$ unique variance.

\section{Discussion}

The results of the study apply to the situation of informal caregivers of applicants to nursing homes and homes for the aged still living in the community. It should be mentioned, though, that applicants in poor mental state or with complex home situations were underrepresented in the study population. This means that the results probably give a more or less optimistic picture of the actual situation of informal caregivers of applicants to nursing homes and homes for the aged: in reality, the situation and problems of these caregivers might be more serious.

The resuits of the analyses provide an answer to the question whether informal caregivers of nursing home applicants experience more strain than those of applicants to homes for the aged, and give some insight into the strain experienced, as measured with the CSI. To begin with the latter, it emerged from the bivariate analysis that most of the factors inventoried were not only associated with the strain experienced, but were also interrelated. When the factors were considered together, it was found that only three variables had a clearly independent association with the strain experienced, viz. the type of caregiving, feelings of loneliness and self-rated health. The amount of ADL care given by the informal caregivers and the measures of the care needs of the applicant, which were correlated with the strain experienced in the bivariate analysis (ranging from 0.31 to 0.43 ), had no independent association with 
the strain experienced. Looking again at the correlation matrix ${ }_{\text {it }}$ is found that the measures of the care needs of the applicants were highly correlated with the type of caregiving (0.64 and 0.71 ). The amount of $\mathrm{ADL}$ care given by the informal caregiver was highly correlated with the frequency of help given during the night $(0.57)$, which tended to be associated independently with the strain experienced. Apparently, the variables are so interrelated that, when the influence of other variables is controlled for, these variables by themselves no longer provide any additional information on the strain experienced. This is also obvious from the fact that the amount of shared variance of the strain experienced which is explained by the independent variables in the analysis, is greater than the amount of unique variance. The associations of feelings of loneliness and self-rated health with the strain experienced are somewhat difficult to interpret as the study was cross-sectional. On the one hand, it is likely that, in taking care of an infirm elderly person, poor health leads to greater strain. On the other hand, it is also plausible that a higher level of strain affects health. Both explanations might hold, but only a llongitudinal study could clarify these relationships. There was a clear relationship between the type of caregiving and the strain experienced. The bivariate difference in the mean scores on the CSI for both groups of informal caregivers was obvious. Moreover, when the influence of other related variables was controlled for, the strain experienced was found to vary significantly with the type of caregiving, which in itself explained $4 \%$ of its variance. So, as hypothesized, informal caregivers of nursing home applicants indeed experienced more strain than those of applicants to homes for the aged. This difference has to be attributed to other factors than the differences in care needs of the applicants, or in the amount of care given by the informal caregivers and by others, as their influence was controlled for. This is all the more true as the strain experienced is only partially explained by the factors in the analysis, which as such is consistent with other research (Gwyther and George 1986; Zarit et al. 1986), although the total percentage of explained variance was reasonable ( $42 \%$ adjusted). Apparently, other factors than those inventoried, such as coping behavior, contribute to the strain experienced. The question whether the different disease history and poorer prognosis of nursing home applicants and/or the more negative image of a nursing home are responsible for the difference in strain by the type of caregiving, cannot be answered from this study. It might be true, but it is also plausible that informal caregivers of nursing home applicants differ in other respects from those of applicants to homes for the aged. Their involvement with the applicants and their willingness to take care of them might differ, as is also suggested by the fact that the informal caregivers of nursing home applicants were taking care of more severely handicapped elderly persons. Further research is warranted to gain a better understanding of the strain experienced and the factors that are responsible for the difference in strain experienced by informal caregivers of applicants to nursing homes and homes for the aged.

We conclude that gaining insight into the strain experienced may help in deciding at an individual level how urgent institutionalization is for an elderly person. Furthermore, if services are to be allocated efficiently, knowledge of the strain experienced might be used to select those situations in which (more) home care or respite care might reduce the burden on the caregiver. In this way, institutionalization might be postponed or even prevented altogether, in a way which takes the interests of informall caregivers into account. 


\section{References}

Bisscheroux PFLA, Frederiks CMA. Thuiswonende ouderen en het gebruik van professionele hulp. Geleen: Gezondheidsdienst Westelijke Mijnstreek, 1985.

Branch LG, Jette AM. A prospective study of long term care institutionalization among the aged. American Journal of Public Health $1982 ; 72: 1373-1379$.

Brody SJ, Poulshock SW, Masciocchi CF. The family caring unit: a major consideration in the long term support system. The Gerontologist 1978; 18: 556-561.

Cantor MH. Strain among caregivers: a study of experience in the United States. The Gerontologist 1983; 23: 597-604.

Colerick EJ, Georgle LK. Predictors of institutionalization among caregivers of patients with Alzheimer's disease. Journal of the American Geriatrics Society 1986; 34: 493498.

Evashwick C, Rowe G, Diehr P, Branch L. Factors explaining the use of health care services by the elderly. Health Services Research $1984 ; 19 ; 357-382$

Fengler AP, Goodrich N. Wives of elderly disabled men: the hidden patients. The Gerontologist 1979; 19: 175-183.

Ferraro KF. Self-ratings of health among the old and old-old. Journal of Health and Social Behavior 1980; 21: 377-383.

Gwyther LP, George LK. Symposium caregivers for dementia patients: complex determinants of well-being and burden. The Gerontologist 1986; 26: 245-247.

Huijsman R, Rutten FFH (red). Economie van de ouderenzorg. Assen/Maastricht: Van Gorcum 1989.

Jong de-Gierveld J. Operationalisering van het begrip eenzaamheid. Sociologische gids $1978 ; 25: 94-118$.

Katz $S$, Akpom CA. A measure of primary sociobiological functions, International Journal of Health Services 1976; 6: 493-507.

Lawton MP. Brody EM. Saperstein AR. A controlled study of respite service for caregivers of Alzheimer's patients. The Gerontologist 1989; 29: 8-16.

Linn BS, Linn MW. Objective and self-assessed health in the old and very old. Social Sciences and Medicine 1980; 14A: 311-315.

Poulshock SW, Deimling GT. Families caring for elders in residence: issues in the measurement of burden. Journal of Gerontology 1984; 39 : 230-239.

Robinson B. Thurnher M. Taking care of aged parents: a family cycle transition. The Gerontologist 1979; 19: 586-593. 
Robinson BS. Validation of a Caregiver Strain Index. Journal of Gerontology 1983; 38 : 344-348.

Rossum HJL van, Frederiks CMA, Philpsen $H$, Knipschild PG, Portengen J. Self-rated health by elderly people living at home. An inventory by means of a postal questionnaire. Tijdschrift voor Sociale Gezondheidszorg 1989; 11: 16.

Smyer MA. The differential usage of serwices by impaired elderly. Journal of Gerontology $1980 ; 35: 249-255$.

Soldo B. Myllyluoma J. Caregivers who live with dependent elderly. The Gerontologist $1983 ; 23: 605-611$.

Tobin $S S_{n}$ Kulys $\mathrm{R}$. The family in the institutionalization of the elderly. Journall of Social Issues 1981; $37: 145-157$.

Worcester MJ Quayhagen MP. Correlates of caregiving satisfaction: prerequisites to elder home care. Research in Nursing and Health 1983; 6: 61-71.

Zarit SH, Reever KE, Bach-Peterson J. Relatives of the impaired elderly: correlates of feelings of burden. The Gerontologist 1980; 20: 649-655.

Zarit SH, Todd PA, Zarit JM. Subjective burden of husbands and wives as caregivers: a longitudinal study. The Gerontologist 1986; 26: 260-266. 


\section{HOOFDSTUK 7}

HET VERLOOP VAN VERPLEEGHUISOPNAMEN*

Margreet JM te Wierik, Carla MA Frederiks, APh Visser, F Sturmans 


\section{Samenvatting}

Dit hoofdstuk beschrijft het verloop van de verpleeghuisopname van 157 nieuw opgenomen patiënten met behulp van de Beoordelingsschaal Oudere Patiënten. Zij zijn voor een periode van maximaal 1 jaar gevolgd. Nagegaan is of het verloop verschilt naar het doel van de opname (reactivering versus permanente ondersteuring) en of er voor de groep reactiveringspatienten ontslag belemmerende danwel bevorderende factoren aan te wijzen zijn. Daarbij werd tevens gebruik gemaakt van informatie van de behandelend verpleeghuisarts over de diagnosen, prognose, (het bereiken van) de behandeldoelen en de SIVIS-validiteit.

De verpleeghuisopname bleek woor chronische en reactiveringspatiënten verschillend te verlopen. Met uitzondering van de lichamelijke invalidite it en depressief gedrag hadden de chronische patienten vanaf de opname meer gedragsproblemen dan de reactiveringspatiènten. Hun hulpbehoevendheid, lichamelijke en psychische invaliditeit alsmede de inactiviteit namen bovendien toe tijdens de opname. Bij tweederde van de reactiveringspatienten leidde de opname niet tot functieverbetering en ontslag uit het verpleeghuis. Bij deze groep namen de hulpbehoevendheid, agressiviteit en het depressief gedrag toe tijdens de opname.

Het succes van de reactivering bleek samen te hangen met de mate van gledragsproblemen, validiteit en de medische toestand bil opname. De minst hulpbehoevende en de 'medisch minst complexe' patiënten konden veelal met functieverbetering ontslagen worden, hetgeen de verpleeghuisopname legitimeert. Het niet beschikbaar zijn van andere zorgvoorzieningen was in een klein aantal gevallen een ontslagbelemmerende factor. Verblijf in een verzorgingshuis als alternatief voor verpleeghuiszorg voor de chronische patiënten, maar ook voor de reactiveringspatiënten die na een jaar nog opgenomen zijn, lijkt, gezien de mate van gedragsproblemen, niet eenvoudig te realiseren.

\section{Summary}

\section{The course of nursing home stays}

This chapter describes the course of the nursing home stays of 157 newly admitted patients using the Behavior Rating Scale for Elderly Patients ('Beoordelingsschaal Oudere Patiënten). The follow-up period lasted a maximum of 1 year. It was investigated whether the course differed in relation to the objective of the admission (rehabilitation versus continuous support) and whether factors could be indicated which impeded or advanced the discharge of the rehabilitation patients. For that purpose. information on diagnoses, prognosis, goals of the treatment and their achievement, and disability according to SIVIS (SIG Nursing Home Information System) was also obtained from the physicians in charge at the nursing home.

The course of the nursing home stay differed for chronic and rehabilitation patients. In addition to physical disability and depressive behavior, the chronic patients, from the time of admission onwards, had more behavioral problems than the rehabilitation patients. Moreover, their dependency "physicall and mental disability and inactivity increased during the stay. For two thirds of the rehabilitation patients, the stay did not end in discharge from the nursing home. For this group, the dependency, aggressiveness, and depressive behavior increased during the stay. The outcome of rehabilitation appeared to be related to the extent of behavioral problems, to the level of disability, and to the medical condition at admission. The least disabled and the 'medically least complex' patients could usually be discharged with an improved level of functioning, which seemed to justify the nursing home stay. The lack of availability of other services impeded discharge in a few cases. For the chronic patients, as well as for the rehabilitation patients still resident after 1 year, residency in a home for the aged as an alternative to nursing home care appears difficult to realize, in view of the extent of behavioral problems. 


\section{Inleiding}

Per jaar worden za'n 25.000 ouderen (55+) opgenomen in een verpleeghuis. (SIG 1988). Binnen deze groep kunnen terminale patiënten, reactiveringspatiënten en chronische somatische en psychogeriatrische patiënten worden onderscheiden. Bi] terminale en chronische patiënten is de verwachting dat zij op korte respectievelijk op langere termijn in het verpleeghuis zullen owerlijden. Bij reactiveringspatiënten beoogt de opname expliciet functieverbetering en ontslag uit het verpleeghuis; in de praktijk blijkt echter dat slechts een deel van deze patiërten daadwerkelijk ontslagen wordt (Te Wierik en Frederiks in druk).

Mede in het licht van de veronderstelde grensvervaging tussen verpleeg-en verzorgingshuizen (Ministerie van WVC 1988 en 1989, Remmen 1985), kan inzicht in het verloop van verpleeghuisopnamen en de factoren die daarop van invloed ziln, bijdragen aan het formuleren van een zorgvuldig indicatie- en opnamebeleid. Ingegeven door onder meer de hoge kosten van verpleeghuiszorg en het tekort aan verpleeghuisbedden wordt ernaar gestreefd om verpleeghuisgeindiceerde ouderen meer en meer in verzorgingshuizen te laten verblijven. Daarbij is het van belang om reactiveringspatiënten, waarbij de verpleeghuisopname het gewenste resultaat heeft, te kunnen onderscheiden van degenen waarbij dat niet het geval is. Voor deze patiënten en de chronische patiënten bepaalt de hulpbehoefte en de ontwikkeling daarvan tijdens de opname, het antwoord op de vraag of verblijf in een verzorgingshuis voor hen een realistisch alternatief is.

In een eerder artikel is verslag gedaan van een onderzoek bij 157 op te nemen verpleeghuispatiënten ( $T \in$ Wierik et al. 1991). Na de opname zijn zij voor een periode van maximaal 1 jaar gevalgd. Dit artikel geeft het verloop van de opnamen weer met belhulp van de Beoordelingsschaal Oudere Patiënten (BOP, Van der Kam et al. 1971). Nagegaan wordt of het verloop van de opname verschilt naar doel van de opname en op welke subschalen van de BOP reactiveringspatiënten zich onderscheiden van chronische patiënten. Voor de groep reactiveringspatiënten wordt nagegaan of er factoren aan te wijzen zijn die ontslag uit het verpleeghuis bevorderen dan wel belemmeren.

\section{Opzet en ultvoering van het onderzoek}

Het onderzoek bij 157 verpleeghuispatiërten vond plaats in Maastricht gedurende de periode februari 1987 tot en met juli 1989. Terminale patiënten waren uitgesloten van het onderzoek, onder andere omdat deelname te belastend zou zijn (een deel van de gegevens werd verzameld met mondelinge interviews). Omwille van de privacy wer. den de verpleeghuispatiënten of een centrale verzorger eerst door de maatschappelijk werkenden van de verpleeghuizen tijdens het huisbezoek benaderd voor medewerking aan het onderzoek. Omdat zij het vragen om medewerking moeilijk en conflicterend met het eigenijike doel van het huisbezoek vonden, heeft deze procedure geleid tot een ondervertegenwoordiging van patiënten met een moeilijke of complexe situatie voorafgaand aan de verpleeghuisopname. Niettemin kwam uit vergelijking met lande. lijke cijfers naar voren dat de deelnemers aan het onderzoek bij opname minstens zo hulpbehoevend waren als verpleeghuispatiënten in het algemeen: het landelijk gemiddelde van de SIVIS-hulpindex bij opname bedroeg in 1987 7.13 (SIG 1988), voor de patiënten in het onderzoek was dit 7.98 (Te Wierik et al. 1991).

De patiënten werden maximaal 1 jaar gevolgd. De veronderstelling daarbij was dat binnen 1 jaar de reactiveerbare patiënten uit het verpleeghuis zouden zijn onkslaglen en dat zij die na 1 jaar nog opgenomen waren 'long-stay" patiënten zouden worden. 
De gegevens werden op 2 manieren verzameld. Het verplegend personeel van de afdeling waar de patiënt verbleef vulde 2 weken na opname en vervolgens om de 3 maanden een BOP in. De BOP geeft inzicht in 6 gedragsaspecten: hulpbehoevendheid, agressiel gedrag, lichamelijke invaliditeit, depressief gedrag, psychische invaliditeit en inactivitelit. In de loop der jaren is de BOP voor deze categorie ouderen een bruikbare schaal gebleken; de validiteit en betrouwbaarheid van het instrument zijn goed te noemen (Diesfeldt 1981).

Naast de gedragsbeoordeling door het verplegend personeel vulde de behandelend verpleeghuisarts bil opname en bij ontslag of overlijden c.q. na 1 jaar opname een schriftelijke vragenlijst in. De vragen hadden betrekking op de diagnosen, de validiteit, (het bereiken van) de behandeldoelen en de prognose. Tabel 1 geeft een overzicht van deze vragen; waar relevant zijn tevens de schaaltechnische gegevens vermeld. Bij] de diagnosen, het doel van de opname en de validiteit is gebruik gemaakt van de classificaties van het SIVIS-registratiesysteem (SIG 1984). De door ons gehanteerde codering van de validiteitsvragen wijkt enigszins af van de SIVIS-codering. Een aantal validiteitsvragen (bijvoorbeeld naar gehoor, communicatie, staan en lopen) heeft als antwoordmogelijkheid "niet te beoordelen (bijvoorbeeld coma)' of 'niet van toepassing (volledig bedlegerig)'. Deze antwoordmogelijkheden worden door SIVIS gecodeerd als geen hulp nodig. Wij hebben, in navolging van Van der Kam en Hoeksma (1989), deze antwoordmogelijkheden herleid tot hulp nodig. Aldus is de onderschatting van de mate van invaliditeit, die optreedt bij de SIVIS-codering, gecorrigeerd.

De BOP-scores zijn op verschillende manieren geanalyseerd. Ingedeeld naar het doel van de opname zijn op groepsnivo gemiddelde scores berekend en uitgezet tegen de verblijfsduur. Vervolgens is per groep, met behulp van gepaarde t-toetsen over de eerst en laatst gemeten BOP, nagegaan of de gedragsstoornissen van individuele patiënten tijdens de opname toe- of afnemen. Om te beoordelen of de gedragsstoornissen verschillen tussen de groepen zijn ongepaarde t-toetsen uitgevoerd. Wanneer de vergelijking meer dan 2 groepen betrof zijn univariate variantie-anallyses uitgevoerd volgens de Scheffé methode. Om kanskapitalisatie te vermijden hanteert deze methode striktere criteria voor statistische significantie van verschillen tussen groepsgemid. delden dan bijvoorbeeld afzonderlijke t-toetsen: de verschillen tussen groepsgemiddelden moeten groter zjjn om als verschil aangemerkt te worden. De kans, om groepen ten onrechte als verschillend wan elkaar te benoemen, wordt hierdoor werkleind. De validiteitsgegevens zilin eveneens met behulp van gepaarde t-toetsen en univariate variantie-analyses bewerkt. Er is steeds tweezijdig getoetst.

\section{Resultaten}

\section{Het verloop naar doel van de opname}

In tabel 2 is een aantal kenmerken van de verpleeghuispatiënten weergegeven naar het doel van de opname. Bij $54 \%$ van de patiënten was het doel van de opname permanente ondersteuning (in het vervolg aangeduid met chronische patiënten), $35 \%$ werd ter reactivering opgenomen en $11 \%$ was voor een ander doel opgenomen. De reactiveringspatiënten zijn wat jonger dan de chronische patiënten: $64 \%$ respectiewelijk $83 \%$ is bij opname 75 jaar of ouder. Psychische stoornissen (veelal dementie) en aandoeningen van het hartwaatstelsel (waaronder de cerebrovasculaire accidenten (CVA) zijn bij opname de belangrijkste hoofddiagnosen voor de chronische patiënten. Bij de reactiveringspatiënten zijn de hoofddiagnosen wat meer divers; de meest voorkomende zijn eveneens aandoeningen van het hartvaatstelsel en ongevalsletsels. Na eén jaar is bijna een derde van de reactiveringspatiënten ontslagen, $40 \%$ is nog 
opgenomen en $29 \%$ is overleden. Bij de chronische patiênten is bijna de helft overleden na één jaar; de andere helft is nog opgenomen. Dit komt ook naar voren uit de verblijfsduur.

Tabel 1. De onderzoeksvariabelen van de schriftelijke vragenlijsten met hun operationalisatie

Variabelen Operationalisatie, range en Cronbach's a

\section{Achtergrondkenmerken ${ }^{y}$ Leeftijd}

Geslacht

\section{Opname gerelateerde}

kenmerken

Doel van de opname' Onderscheid in 1) verblijf voor onbepaalde duur "de behandeling is gericht op het permanent ondersteunen wan een aantal levensfuncties; 2) reactive. ring, de behandeling beoogt functieverbetering en ontslag uit het verpleeghuis; 3) andere doelen

Behandeldoelen' in geval van reactivering: het verwachte resultaat van de reactivering, onder scheiden naar gedrag, contactfuncties, ADL, mobiliteit en continemtie

Bereiken van de

behandeldoelen ${ }^{2}$

De behandeldoelen zijn geheel, ten dele of niet bereikt; in geval wan ten dele of niet bereiken: de reden daarvan

Proginose"

Beoordeling bij opname over de meest waarschijnlijke situatie van de patient over één jaar: overleden, nog opgenomen of ontslagen

Ontslag ${ }^{2}$

Directe vraag of ontslag naar huis of naar een verzorgingshuis is overwogen tijdens de opname

Vallititeit $^{1-2}$

$A D L$

ADL-score = de som van 5 ADL activiteiten waarbij men hulp nodig hẻeft; het betreft wassen boven en onder, kleden, toiletbezoek en eten; range: $0-5 ; \alpha=0.71$

Mobiliteit

Invaliditeit

Mobiliteit-score $=$ de som van 4 mobiliteitsprablemen; het betreft in en uit bed gaan, lopen, staan en uithoudingsvermogen (langer versus korter dan 6 uur per dag op); range: $0-4 ; a=0.83$

Invaliditeitsscore $=\mathrm{ADL}$-score + mobiliteit-score + het aantal problemen met gedrag, gehoor, actieve en passieve communicatie (in woord, schrift of gebaar) en incontinentie voor urine en faeces; range: $0-15 ; a=0.83$

\section{Diagnosen ${ }^{1}$}

Aantal diagnosen

Het aantal diagnosen bij opname; maximaal konden 3 diagnosen benoemd worden; range: $0-3$

Hoolddiagnose

De hoofddiagnose is de aandoening die de validiteit het meest beperkt

1 Deze kenmerken zijn bij opname geïnventariseerd.

2 Deze kenmerken zijn bij ontslag of overlijden c.q. na 1 jaar opname geinventariseerd. 
Tabell 2. Enkele kenmerken van de verpleeghuispatienten naar doel van de opname (\%)

\begin{tabular}{|c|c|c|c|c|c|}
\hline & & $\begin{array}{l}\text { Permanente } \\
\text { ondersteuning } \\
(n=84)\end{array}$ & $\begin{array}{l}\text { Reactiveren } \\
(n=55)\end{array}$ & $\begin{array}{l}\text { Anders } \\
(n=18)\end{array}$ & $\begin{array}{l}\text { Totaal } \\
(n=157)\end{array}$ \\
\hline Geslacht & man & $\begin{array}{l}25(30) \\
59(70)\end{array}$ & $\begin{array}{l}16(29) \\
39(71)\end{array}$ & $\begin{array}{r}8(44) \\
10(56)\end{array}$ & $\begin{array}{r}49(31) \\
108(69)\end{array}$ \\
\hline Leeftijd & $\begin{array}{l}55-64 \\
65-7.4 \\
75-84 \\
85+\end{array}$ & $\begin{array}{r}3(4) \\
12(14) \\
42(50) \\
27(32)\end{array}$ & $\begin{array}{l}2(3) \\
18(33) \\
23(42) \\
12(22)\end{array}$ & $\begin{array}{l}3(17) \\
3(17) \\
8(44) \\
4(22)\end{array}$ & $\begin{array}{r}8(5) \\
33(21) \\
73(47) \\
43(27)\end{array}$ \\
\hline $\begin{array}{l}\text { Hootd- } \\
\text { diagnose }\end{array}$ & $\begin{array}{l}\text { Psychische } \\
\text { stoornissen } \\
\text { Hartwaatsielsel } \\
\text { Ongevaisletsels } \\
\text { Nieuwvormingen } \\
\text { Aanwullende } \\
\text { classificatie" } \\
\text { Zenuwstelsel/zintuigen } \\
\text { Overig }\end{array}$ & $\begin{array}{r}51(61) \\
18(21) \\
2(2) \\
3(4) \\
\\
5(6) \\
5(6)\end{array}$ & $\begin{array}{r}2(4) \\
18(33) \\
11(20) \\
4(7) \\
7(13) \\
2(4) \\
11(20)\end{array}$ & $\begin{array}{l}2(11) \\
7(39) \\
6 \\
6(33)\end{array}$ & $\begin{array}{r}55(35) \\
43(27) \\
13(8) \\
13(8) \\
8(5) \\
8(5) \\
17(11)\end{array}$ \\
\hline$\frac{\text { Verblijes }}{\text { duur }}$ & $\begin{array}{l}\text { 0. } 1 \text { maand } \\
\text { 2- } 3 \text { maanden } \\
\text { 4. } 6 \text { maanden } \\
7 \text { - } 9 \text { maanden } \\
\text { 10-12 maanden }\end{array}$ & $\begin{array}{r}2(2) \\
8(10) \\
12(14) \\
15(18) \\
47(56)\end{array}$ & $\begin{array}{r}1(2) \\
12(22) \\
8(15) \\
8(15) \\
26(47)\end{array}$ & $\begin{array}{l}4(22) \\
2(11) \\
6(33) \\
1(6) \\
5(28)\end{array}$ & $\begin{array}{l}7(4) \\
22(14) \\
26(17) \\
24(15) \\
78(50)\end{array}$ \\
\hline $\begin{array}{l}\text { Situatie } \\
\text { na 1 jaar }\end{array}$ & $\begin{array}{l}\text { Overleden } \\
\text { Nogi opgenomen } \\
\text { Ontslagen }\end{array}$ & $\begin{array}{r}39(46) \\
43(51) \\
2(2)\end{array}$ & $\begin{array}{l}16(29) \\
22(40) \\
17(31)\end{array}$ & $\begin{array}{l}9(50) \\
5(28) \\
4(22)\end{array}$ & $\begin{array}{l}64(41) \\
70(44) \\
23(1.5)\end{array}$ \\
\hline
\end{tabular}

1 tot deze categorie aandoeningen behoren onder meer: status na heupoperatie, amputatiestatus en overige status na operatie of orthopedische ingreep.

2 inclusiof de na 12 maanden nog opgenomen patienten

3 inclusief 3 patienten die naar het ziekenhuis ontslagen werden en daar binnen 1 week overleden

In totaal werden van 149 van de 157 patiënten éen of meerdere BOP-scores verkregen. In de figuren 1 tot en met 6 zijn de gemiddeide BOP-scores naar doel van de behandeling in verband gebracht met de verblijfsduur. De patiënten die voor andere doelen dan reactivering of permanente ondersteuning werden opgenomen, zijn niet in de figuren weergegeven, omdat zij een kleine en heterogene groep vormen. De figuren laten zien dat de chronische patiënten over de gehele periode in het algemeen meer problemen hebben dan de reactiveringspatiënten. Alleen de lichamelijke invaliditeit en het depressief gedrag wijken hiervan af. Het verschil in lichamelijke invaliditeit bij opname neemt af met het toenemen van de verblijfsduur; na én jaar is er geen verschil meer tussen beide groepen. Het omgekeerde geldt voor depressief gedrag: aanvankelijk is er geen verschil, maar vanaf $\mathbf{3}$ maanden vertonen de reactiveringspatiënten meer depressief gedrag dan de chronische patiënten. Overigens verschillen de groepen op deze twee subschalen het minst: de lijnen liggen dicht bij elkaar. 


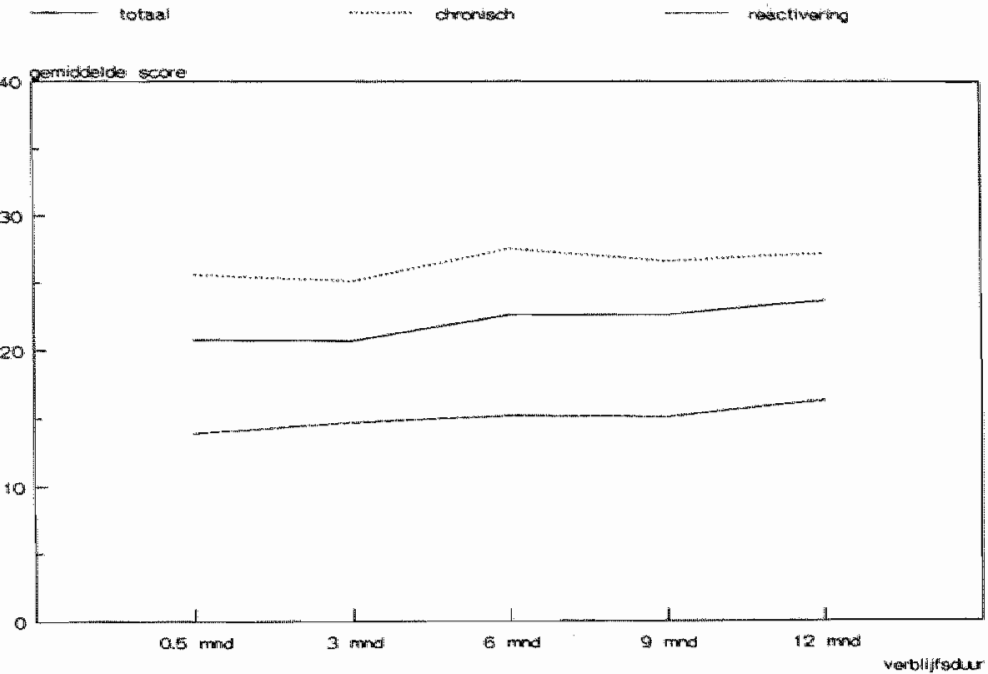

\begin{tabular}{|c|c|c|c|c|}
\hline N(Fothel) $=$ & 107 & 134 & 1月目的 & 9 \\
\hline Nictoron $)$ & 59 & 74 & 67 & 58 \\
\hline N(reach) $=$ & 3 & 47 & औज & 30 \\
\hline
\end{tabular}

Figuur 1. Hulpbehoevendheid

totaial

ctromisch:

roactivering

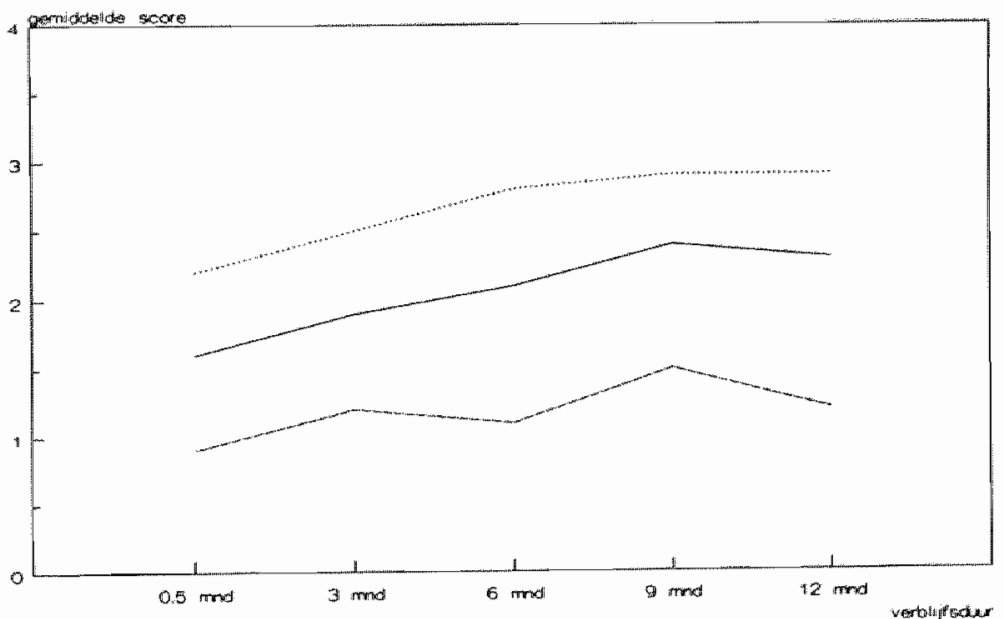




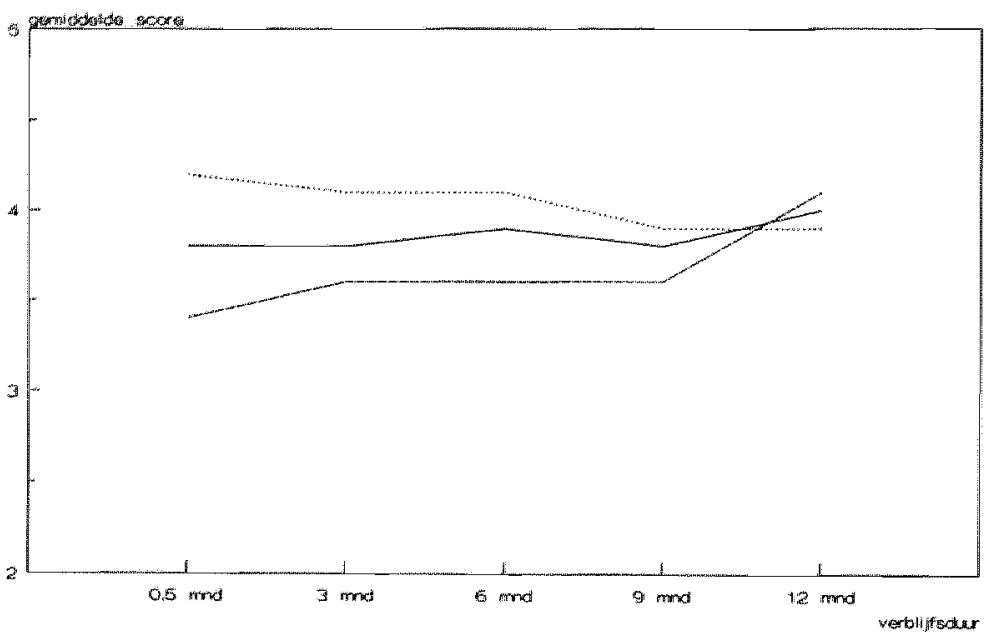

Figuur 3. Lichamelijke invaliditeit

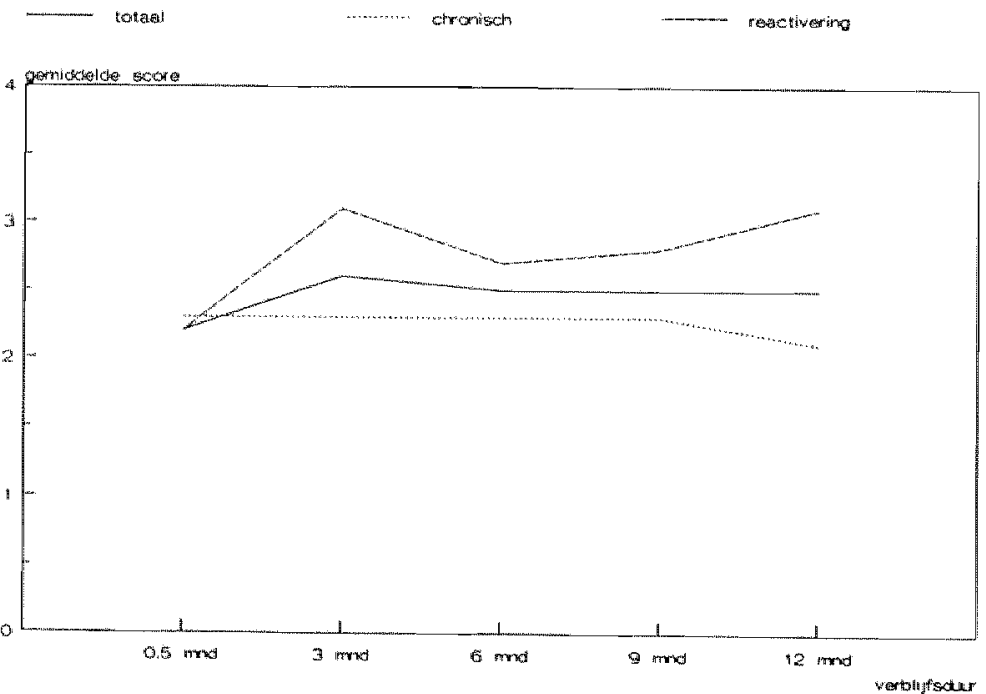

Figuur 4. Depressief gedrag 


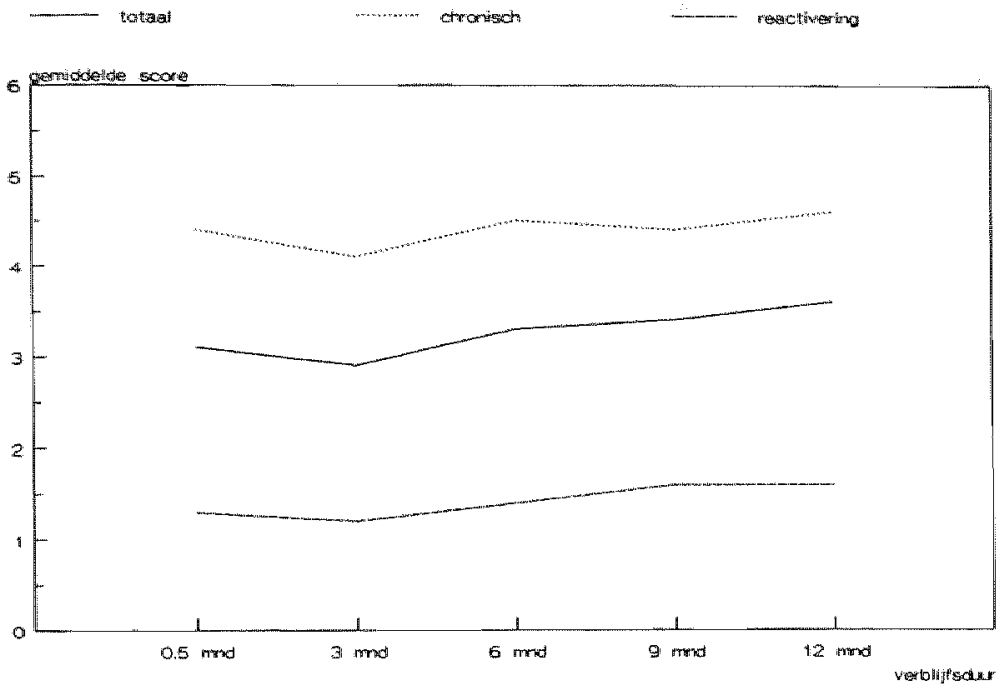

Figuur 5. Psychische invaliditeit

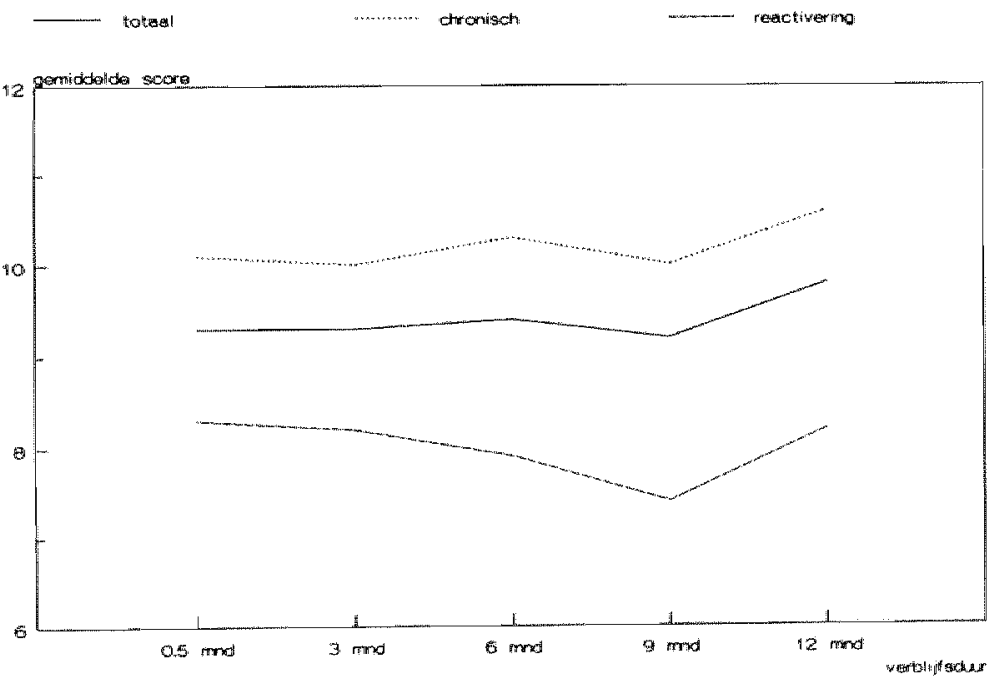

Figuur 6 . Inactiviteit 
Benadrukt moet worden dat hel aantal patiënten wisselt per meetmoment en dat het aantal wanaf de tweede meting anneemt ten gevolge van ontslag en overlijen. Dit verklaart ook waarom het verloop van de gemiddelde scores op alle subschalen van de BOP vrij constant is. Door overlijden van de meest hulpbehoevenden en ontslag van de minst hulpbehoevenden bllift de hulpbehoevendheid van dle nog opgenomen patienten per saldo ongeveer gelijk. Door deze uitstroom is het verloop van de opname bilj de patênten uit de aanvankelijke groepen niet uit deze figuren af te leiden. Om het effect van deze selectieve uitval te elimineren zijn de resultaten van gepaarde t-toetsen over de eerst en laatst gemeten BOP weergegeven in tabel 3. Het verschil met de figuren is dat in tabel 3 het aantal patiënten constant is, maar dat de tijd tussen de eerst en laatst gemeten BOP per patiënt verschilt. Tabel 3 bevestigt de bevindingen van de figuren, in de zin dat de chronische patiënten in het algemeen meer gedragsproblemen hebben dan de reactiveringspatienten. Alleen de lichamelijke invaliditeit, zowel bij opname als biij de laatste meting, en het depressief gedrag bij opname wan de chronische patiënten bleken niet significant te verschillen van die van de reactiveringspatiënten. Uit tabel 3 is verder af te leiden dat de gedragsproblemen bij de chronische patiënten toenemen tijdens de opname, hetgeen verwacht mocht worden. De gemiddelde scores op de subschalen hulpbehoevendheid, lichamelijke invaliditeit, psychische invaliditeit en inactiviteit zijn aan het eind van de opname c.q na één jaar sigificant hoger dan aan het begin van de opname. Alleen wat agressiviteit en depressief gedrag betreft zijn er geen duidelijke veranderingen tijdens de opname. De resultaten bij de reactiveringspatiënten laten het volgende zien.

Het nivo van lichamelijke en psychische invaliditeit en van inactiviteit na één jaar opname c.q. bij ontslag of overlijden is ongeveer gellik aan dat bij opname. De subschalen hulpbehoevendheid, agressiviteit en depressief gedrag laten wel verschillen zien: de problemen op deze gebieden nemen toe.

Tabel 3. Gemicldelde scoros aver de cerst on laatst gemeten BOP naar doel wan de ophame $(n=133)$

\begin{tabular}{|c|c|c|c|c|c|c|c|c|c|c|}
\hline \multicolumn{2}{|c|}{$\begin{array}{l}\text { BOP-gichathan } \\
\text { (range) }\end{array}$} & \multicolumn{2}{|c|}{$\begin{array}{l}\text { Feactiveron } \\
(n=54)\end{array}$} & & & \multicolumn{4}{|c|}{$\begin{array}{l}\text { Permanente } \\
\text { andersteuning } \\
(n=79)\end{array}$} & \multirow[t]{2}{*}{$\begin{array}{l}\text { Verschillen } \\
\text { fussen de } \\
\text { groepen }\end{array}$} \\
\hline & & $x_{1}$ & (sod) & $x_{2}$ & $(s d)$ & $x_{1}$ & (sd) & $x_{2}$ & $(\mathrm{scl})^{\mathrm{e}}$ & \\
\hline 1 & $\begin{array}{l}\text { Nulpbahomondhoid } \\
\text { (0.46) }\end{array}$ & 13,6 & $(7,3)$ & 16.2 & $(9,6)^{2}$ & 25,6 & $(8,6)$ & 28,4 & $(8,4)$ & : \\
\hline 2 & $\begin{array}{l}\text { Agressivilitint } \\
(0-10)\end{array}$ & 0,9 & $(1,6)$ & 1,3 & $(2,0) *$ & 2.4 & $(2,6)$ & 2,5 & $(2,5)$ & 5 \\
\hline $3 \mathrm{~A}$ & $\begin{array}{l}\text { Lidhamelijke Inwa- } \\
\text { liditert: }(\mathrm{O}-6)\end{array}$ & 3.3 & $(1,3)$ & 3.7 & $(1,7)$ & 4,0 & $(1,8)$ & 4,4 & $(1, \pi)=$ & ms \\
\hline 39 & $\begin{array}{l}\text { Dopplonglof gedirag } \\
(0-6)\end{array}$ & 2,4 & $(1,4)$ & 3,0 & $(1,5)^{*}$ & 2.4 & $(1,5)$ & 2,1 & $(1,4)$ & bij: opname ns \\
\hline 30 & $\begin{array}{l}\text { Poyyohilocho inwa. } \\
\text { liditeit }(0-8)\end{array}$ & 1,2 & $(\pi, 4)$ & 1,4 & $(1,0)$ & 4,4 & $(1,6)$ & 4,7 & $(1,9)$ & 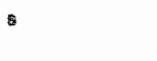 \\
\hline 4 & $\begin{array}{l}\text { Intactivitait } \\
(0-14)\end{array}$ & 8,11 & $(2,6)$ & 8.5 & $(3,2)$ & 9.9 & $(3,1)$ & 11,1 & $(2,4)$ & 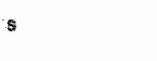 \\
\hline
\end{tabular}

a Bij 6 chronische respectiovelijk. 7 reactiveringspationten is de lastst gemeten BOP gelijk aan cle verste.

1) Vorschillen tusean de groepen op basis van ongepaatde t-toetseni" s: $p<0$.05; ns: niet significant

- $X_{i}$ : gemiddalde score oerst gemeten BOP; $X_{2}$ : gemiddalde score latst gemeten BOP; sdi standiardideviatie: $p<0.05$, gepaerde thoets 


\section{Het verloop bij de reactiveringspatiënten}

Uit het voorafgaande blijkt dat het resultaat van de opname bij de reactiveringspatienten teleurstellend is. Ondanks de relatief goede uitgangspositie - in vergelijking met de chronische patiënten zijn zij in het algemeen veel minder hulpbehoevend - bleken de problemen constant te blijven danwel toe te nemen. Hoewel de reactivering zowel functieverbetering van de patiënt als ontslag uit het verpleeghuis beoogt, kwam verbetering op één of meerdere subschalen van de BOP niet voor; slechts een derde van de 55 reactiveringspatiënten werd ontslagen. Om na te gaan waarom de reactivering bij tweederde van de reactiveringspatiënten niet lukt, is een aantal kenmerken van de ontslagen patiënten vergeleken met die van de overleden en de na één jaar nog opgenomen reactiveringspatiënten. Naast de BOP-scores is hierbij gebruik gemaakt van de gegevens die van de verpleeghuisartsen verkregen zijn. In tabel 4 en 5 zijn deze kenmerken weergegeven naar de 'uitkomst' van de opname; er waren geen verschillen in leeftijd en geslacht. Ondanks de kleine aantallen patiënten per groep laten de BOP-scores significante verschillen zien (tabel 4). Dit geldt niet zozeer voor verschillen binnen een groep in de tijd - bij de overleden patiënten nemen alleen de hulpbehoevendheid en het depressief gedrag significant toe tijdens de opname en bij de ontslagen patiënten alleen het depressief gedrag - maar vooral voor verschillen tussen de groepen. Alleen de subschaal agressiviteit blijkt niet te differentieren. De ontslagen patiënten blijken, niet alleen bij de laatste meting maar ook bij opname, op alle andere subschalen veel minder problemen te hebben dan de overleden patiënten. De nog opgenomen patiënten nemen op beide meetmomenten een tussenpositie in.

Tabel 4. BOP-scores en waliditeit-scores van de reactiveringspatienten naar 'uitkomst' van de opname $(n=55)$

BOP-schalen

1 Hulpbehoevendheid

2 Agressiviteit

3A. Lichamelijke inwaliditeit

3B Depressief gedrag

3C Psychische invaliditeit

4 Inactiviteit

Valliditeit-scores

ADL-Score

Mobiliteit-score

Invaliditeitsscore
Overleden

(OV, $n=16$ )

$x_{1} \quad x_{2}$

19,8

1,6

4,1

3,4

1,8

0,0

24,7
2,1
4,4
3,9
2,4
1,11

4,1

4,8 *

2,8

$3,7 *$

$8,4 \quad 10,7 *$
Nog opgenomen Ontslagen

$(N O, n=22) \quad(0, n=47)$
Verschillen

tussen de groepen 
De validiteitsgegevens geven een wat ander beeld (tabel 4). Zowel de ADL, de mobiliteit- als de invaliditeitsscore nemen toe bij de overleden patiënten en nemen af bij de ontslagen patiënten. Bil opname blijkt alleen de invaliditeitsscore van de ontslagen patiënten te verschillen van die van de overleden patiënten.

De hoofddiagnose bili opname levert geen aanwijzingen voor een goede reactivering (tabel 5). Patiënten met nieuwwormingen en aandoeningen wan het bewegingsstelsel zijn mogelijk slecht te reactiveren; geen van deze patiënten werd ontslagen. Het aantal diagnosen bij opname hangt wel samen met de uitkomst van de opname: patiënten met minder diagnosen worden vaker ontslagen terwil patiënten met meer diagnosen vaker overlijden of nog opgenomen zijn (Kendall's tau is $-0.25, p<0.02$ ). De verpleeghuisartsen hadden bij een deel van de patienten blijkbaar zelf al enige twiffels over de haalbaarheid van de reactivering: hoewel zij ontslag naar huis of naar een verzorgingshuis het meest waarschijnlijk vonden bij de meeste patiënten, konden zij bij 5 patiënten de situatie over 1 jaar moeilijk voorspellen en was bij 9 patiënten de verwachting dat zij nog opgenomen zouden zijn. Dat deze patiënten inderdaad niet ontslagen zijn lijkt geen toeval.

Tabel 5. Enkele kenmerken van de reactiveringspatięnten naar 'uitkomst' van de opname $(n=55)$

\begin{tabular}{|c|c|c|c|c|c|}
\hline & & $\begin{array}{l}\text { Overleden } \\
(O V, n=16)\end{array}$ & $\begin{array}{l}\text { Nog opgenomen } \\
(N O, n=22)\end{array}$ & $\begin{array}{l}\text { Ontslagen } \\
\left(O_{n} n=17\right)\end{array}$ & $\begin{array}{l}\text { Totaal } \\
(n=55)\end{array}$ \\
\hline \multirow[t]{6}{*}{ Hoofddiagnose } & Hartwaatstelsel & 5 & 9 & 4 & 18 \\
\hline & Ongevalsletsels & 3 & 3 & 5 & 11 \\
\hline & $\begin{array}{l}\text { Aanvullende } \\
\text { classificatie }\end{array}$ & . & 3 & 4 & 7 \\
\hline & Bewegingstelsel & 2 & 3 & $\begin{array}{l}4 \\
-\end{array}$ & 5 \\
\hline & Nieuwwarmingen & 3 & 1 & - & 4 \\
\hline & Overig & 3 & 3 & 4 & 10 \\
\hline \multirow[t]{3}{*}{ Aantal diagnosen } & 1 & 2 & 2 & 6 & 10 \\
\hline & 2 & 3 & 8 & 5 & 16 \\
\hline & 3 & 11 & 12 & 6 & 29 \\
\hline \multirow[t]{4}{*}{ Prognose } & Overteden & 1 & - & - & 1 \\
\hline & Nog opgenomen & 4 & 5 & $\circ$ & 9 \\
\hline & Ontslagen & 10 & 13 & 17 & 40 \\
\hline & Onduidelijk & 1 & 4 & - & 5 \\
\hline \multirow{4}{*}{$\begin{array}{l}\text { Behandeldoelen } \\
\text { voor } A D L \text { en } \\
\text { mobiliteit }\end{array}$} & Belide verbeteren & 10 & 13 & 10 & 33 \\
\hline & Verbeteren/zelfstandig & 1 & 3 & 4 & 8 \\
\hline & Beide zelfstandig & 4 & 2 & 3 & 9 \\
\hline & Anders/nivt & 1 & 4 & - & 5 \\
\hline \multirow{4}{*}{$\begin{array}{l}\text { Bereiken } \\
\text { behandeldoelen }\end{array}$} & $\begin{array}{l}\text { Beide geheel bereikt } \\
\text { Beide minimaal ten }\end{array}$ & - & 1 & 13 & 14 \\
\hline & $\begin{array}{l}\text { dele bereilkt } \\
\text { Beide maximaal niet }\end{array}$ & 1 & 5 & 3 & 9 \\
\hline & bereikt & 14 & 15 & 1 & 30 \\
\hline & Andiers/nvt & 1 & 1 & - & 2 \\
\hline \multirow{2}{*}{$\begin{array}{l}\text { Ontslag } \\
\text { overwogen }\end{array}$} & Ja & 5 & 10 & nvt & 15 \\
\hline & Nee & 11 & 12 & nut & 23 \\
\hline
\end{tabular}


Voor aile reactiveringspatiènten werd gevraagd het verwachte resultaat van de reactivering aan te geven, onderscheiden naar gedrag, contact-functies, $A D L$, mobiliteit en continentie. Omdat voor gedrag, contact-functies en continentie vaak (bij meer dan $60 \%$ ) geen behandeldoel werd omschreven, zijn in tabel 5 alleen de doelen voor ADL en mobiliteit samengevat. Opvallend is dat slechts bij 9 patiënten zelfstandig functioneren in ADL en mobiliteit nagestreefd werd; het verbeteren van beide kwam het meest voor. De mate waarin de doelen bereikt zijn is in dit geval vrijwel een weerspiegeling van de feitelijke situatie na één jaar. Op 1 patiënt na zijn alle patiënten waarbil beide behandeldoelen bereikt zijn, ontslagen. De patiënten waarbij de doelen niet (geheel) bereikt werden, zijn, op 4 patiënten na, ofwel overleden ofwel nog opgenomen. De redenen voor het niet (geheel) bereiken van de doelen bij de 4 ontslagen patiënten zijn onder meer cathetergebruik en het niet zelf kunnen aantrekken van een been-orthese. Voor de nog opgenomen patiënten zijn de redenen als volgt samen te vatten. De ontwikkeling of het duidelijker worden van een dementieel syndroom speelde bij 4 patiënten een rol. Bij 7 patiënten bleken de handicaps ernstiger te zijn dan gedacht; bij deze patiënten waren de doelen dus te hoog gesteld. Gebrek aan motivatie van de patiënt en algehele achteruitgang werden elk bij 2 patiënten aangegeven. Complicaties, zoals een recidief CVA, operatie of apraxie, werden 6 maal als reden aangegeven. Het lijkt erop dat deze complicaties zich bij een aantal patiënten vrij laat voordeden: bij 10 patiënten is nog ontslag naar huis of naar een verzorgingshuis overwogen. Bij vier daarvan werd verwacht dat ontslag alsnog plaats zou vinden. Men was in afwachting van een voor de patiënt geschikte gezinshulp of van een plaats in een verzorgingshuis (2 maal). De nog opgenomen patiënt waarbij beide behandeldoelen bereikt waren, was in afwachting van een aanleunwoning. Voor de overleden patiënten werden als redenen voor het niet (geheel) bereiken van de doelen aangegeven: algehele lichamelijke en/of psychische achteruitgang ( 8 maal), een (recidief) CVA (4 maal) en overige redenen zoals plotseling overlijden en depressiviteit (4 maal).

\section{Discussie}

\section{Het verloop bij chronische en reactiveringspatiënten}

Het verloop van de verpleeghuisopname bij reactiveringspatiënten is duidelijk verschillend van het verloop bij chronische patiënten. Met uitzondering van lichamelijke invaliditeit en depressief gedrag bleken de chronische patiënten vanaf de opname op alle andere subschalen van de BOP meer problemen te hebben dan de reactiveringspatiënten. Eerder kwamen wij tot de conclusie dat de hulpbehoefte van de op te nemen patiënten, gemeten met een ADL-score, niet verschilde naar het doel van de opname (Te Wierik et al. 1991). Met de BOP, die meer en ook andere informatie geeft dan het aantall ADL-beperkingen, konden dus wel verschillen aangetoond worden. De bevinding dat de lichamelijke invaliditeit geen verschillen liet zien tussen de chronische en de reactiveringspatiënten is overigens wel consistent.

Bij de chronische patiënten bleken de gedragsproblemen op andere gebieden toe te nemen dan bij de reactiveringspatiënten. Alleen de hulpbehoevendheid nam bij beide groepen toe tijdens de opname. De toename in hulpbehoevendheid, lichamellike en psychische invaliditeit en inactiviteit komt voort uit de aard van hun aandoeningen: bij meer dan de helft was de hoofddiagnose een psychische stoornis, hetgeen vrijwel altijd dementie betekende.

Naast de hulpbehoevendheid nam bij de reactiveringspatiënten de agressiviteit en het depressief gedrag toe tijdens de opname. Het laatste zelfs tot een nivo dat hoger was 
dan bij de chronische patienten. Een mogelike verklaring hievvor is dat het ziekteen opnameproces bil hen snel is verlopen; een deel van hen werd immers opgenomen ten gevolge van acute aandoeningen zoals aen CVA of ongevalsletsel. Bovendien is dit de groep die cognitief nog goed functioneert "zil weten dus wat er met hen aan de hand is. Om deze redenen is het plausibel dat het in korte tijd moeten verwerken war de eigen invalliditeit en de opname zijn weerslag heeft op de geestellike toestand; zeker wanneer blijkt dat de reactivering niet het gewenste resultaat heeft en ontslag uit het verpleeghuis niet meer tot de mogelijkheden behoort. De toename in agressiviteit kan op analoge wijze verklaard worden als verzet tegen de huidige situatie. Het kan echter ook samenhangen met het gegeven dat bij een aantal patiënten een dementieel syndroom zich ontwikkelde of duideliker werd tijdens de opname.

\section{Ontslagen versus niet ontslagen reactiveringspatiënten}

De reactivering bleek bij tweederde van de patiënten niet tot ontslag te leiden. De subgroepanalyse liet zien dat de ontslagen patiënten op een aantal kenmerken duide. lijk verschillen van de overleden en de na één jaar nog opgenomen reactiveringspatiénten.

De ontslagen patienten hadden bij opname de minste gedragsproblemen op alle subschalen van de BOP, behalve agressiviteit. Ook scoorden zij gemiddeld het laagst op de invaliditeitsschaal en hadden zij vaker minder diagnosen. De overleden patiënten waren het slechtst af; de nog opgenomen patiënten namen een tussenpositie in. Aanwijzingen dat bepaalde aandoeningen beter te reactiveren zijn dan andere aandoeningen, werden niet gevonden. De minst hulpbehoevende en de 'medisch minst complexe' patienten hadden dus de meeste kans op ontslag. Ook de redenen voor het niet (geheel) bereiken van de behandeldoelen bij de ADL en mobiliteit wijzen hierop: naast de complicaties refereerden de andere redenen veelal naar de algehele conditie. Slechts bij een klein aantal patiënten bleek de beperkte beschikbaarheid van andere zorgvormen een belemmering voor ontslag. Opvallend bij de subgroepanalyse was dat de toename van de validiteit-scores bij de overleden patiënten en de afname daarvan bij de ontslagen patiënten nauwelijks terug te vinden waren in de BOP. scores. Temeer daar Van der Kam en Hoeksma (1989) een correlatie van 0.90 vonden tussen de SIVIS-hulpindex en de score op hulpbehoevendheid van de BOP. Wij vondlen voor de chronische patiënten een correlatie van 0.78 tussen de score op hulpbehoevendheid en de invaliditeitsscore op beide meetmomenten. Voor de reacti. veringspatiénten was dit 0.58 bij opname en 0.80 bij de tweede meting. De score op hulpbehoevendheid is afhankelijk van zowel het lichamelike als het psychische functioneren. Ook bij de invaliditeitsscore spelen beide aspecten een rol "maar het lichamelijk functioneren legt meer gewicht in de schaal. Omdat bij reactiveringspatiênten de opname waak het gevolg is van een min of meer acute aandoening, die wel het lichamelijk maar niet zozeer het psychisch functioneren aantast, zal de invaliditeitsscore voor hen nog meer een uitdrukking van ADL-en mobiliteitsbeperkingen zijn. De discrepantie tussen de correlaties wordt dan veroorzaakt doordat de ene schaal bij opname meer het lichamelijke en de andere meer het psychische aspect meet bij reactiveringspatiènten. Tijdens de opname neemt deze discrepantie af: bij de tweede meting is de correlatie tussen beide schalen bij de reactiveringspatiënten gelijk aan die bij de chronische patiënten. Hoewel de BOP ook in dit onderzoek een bruikbaar instrument is gebleken - het geeft meer en andere informatie dan andere schalen voor hulpbehoefte, zoals ADL-en mobiliteitsschalen - blijken de SIVIS-validiteitsgegevens bij reactiveringspatiênten dus beter te differentierren dan de BOP. 


\section{Vergelijking met ander onderzoek}

Vrij recent is een aantal onderzoekingen bij verpleeghuispatiènten gepubliceerd waarbij gebruik gemaakt is van de BOP (Nan der Kam en Hoeksma 1989, Vink et al. 1989, Van Loo 1990). Een directe vergelijking wordt bemoeilijkt doordat daarin alleen BOP. scores van psychogeriatrische en somatische patiënten gepresenteerd worden; wel is het mogelijk die BOP-scores te vergelijken met de scores van respectievelijk de chronische patiënten en de reactiveringspatiënten uit ons onderzoek. Deze vergelijkingen geven nauwelijks aanwijzingen dat de gedragsproblemen van de patiënten uit ons onderzoek anders zijn dan die van elders verblijvende patiënten. Dit pleit, evenals de vergelijkbaarheid qua hulpbehoefte bij opname met verpleeghuispatiënten in het algemeen, voor de generaliseerbaarheid van onze bevindingen, maar kan dat niet garanderen. Replicatieonderzoek is daarom gewenst.

Vink et al. (1989) vergeleken verpleeghuispatiënten met verzorgingshuisbewoners en vonden grote verschillen in BOP-scores. Zij concludeerden dat deze verschillen onvoldoende steun bieden voor de opvatting dat beide instellingen al bijna niet meer van elkaar te onderscheiden zijn. De belangrijkste accenten in de verzorgingsproblematiek in beide instellingen verschillen duidelijk. Onze resultaten sluiten hier, zij het indirect, bij aan. Dit geldt niet alleen voor de chronische, maar ook voor de reactiveringspatiënten. Hoewel de 'lichtste" verpleeghuispatiënten een voor de hand liggende doelgroep vormen bij het streven verpleeghuiszorg deels te vervangen door verblijf in een verzorgingshuis, wordt de opname-indicatie voor de 'lichtste' reactiveringspatiënten gelegitimeerd door het feit dat zij baat lijken te hebben bij de verpleeghuisopname. Ofschioon gecontroleerd onderzoek nodig is om na te gaan in hoeverre de reactivering, dan wel spontaan herstel, verantwoordelijk is voor de functieverbetering, bleken zij met een betere validiteit ontslagen te worden. De na één jaar nog opgenomen reactiveringspatiënten namen een tussenpositie in wat gedragsproblemen betreft. Het is deze groep waarbij Remmen (1985) stelde dat ze ook in een verzorgingshuis zouden kunnen verblijven. Echter, evenals de chronische patiënten hebben zij, in vergelijking met de verzorgingshuisbewoners uit het onderzoek van Vink et al. (1989), beduidend meer gedragsproblemen. Alleen met aanpassingen in personele en bouwkundige zin zouden deze patiënten in een verzorgingshuis kunnen verblijen. Overigens dient gerealiseerd te worden dat een dergelijke verschuiving van patienten op grote schaal niet alleen de kosten van beide voorzieningen zal verhogen, maar ook het leefklimaat in vooral verzorgingshuizen negatief zal beinvloeden.

Samenvattend kan geconcludeerd worden dat de verpleeghuisopname voor chronische en reactiveringspatiënten verschillend verloopt. Met uitzondering van de lichamelijke invaliditeit en depressief gedrag hebben de chronische patiënten vanaf de opname meer gedragsproblemen dan de reactiveringspatiënten. Hun hulpbehoevendheid, lichamelijke en psychische invaliditeit alsmede de inactiviteit nemen bovendien toe tijdens de opname. Bij tweederde van de reactiveringspatiënten leidde de opname niet tot het gewenste resultaat. De hulpbehoevendheid, agressiviteit en depressief gedrag namen tijdens de opname dan ook toe bij deze groep. Het succes van de reactivering bleek samen te hangen met de mate van gedragsproblemen, validiteit en de medische toestand bij opname. De minst hulpbehoevende en de 'medisch minst complexe' patiënten konden veelal met functieverbetering ontslagen worden, hetgeen de verpleeghuisopname legitimeert. Het niet beschikbaar zijn van andere zorgvoorzieningen was in een klein aantal gevallen een ontslagbelemmerende factor. Verblijf in een verzorgingshuis als alternatief voor verpleeghuiszorg voor de chronische patiënten, maar ook voor de reactiveringspatiënten die na een jaar nog opgenomen zijn, lijkt gezien de mate van gedragsproblemen, niet eenvoudig te realiseren. 


\section{Literatuur}

Diesfeldt HFA. De BOP tien jaar. Gerontologie 1981; 12: 139-145.

Kam $P$ van der, Mol $F$, Wirmmers MFHG. Beoordelingsschaall voor Oudere Patiënten. Deventer, van Loghum Slaterus 1971.

Kam P van der, Hoeksma BH. De bruikbaarheid van BOP en SIVIS voor het schatten van de werklast in het psychogeriatrisch verpleeghuis. Uitkomsten van een tijdnormstellingsonderzoek. Tijdschrift voor Gerontologie en Geriatrie 1989; 20: 159-166.

Loo EH van, Roelofs CAJ, Diesfeldt HFA. Veranderingen in hulpbehoevendheid bij patiënten in een psychogeriatrisch verpleeghuis, bij eerste opname en op peildata. Tijdschrift voor Gerontologie en Geriatrie 1990; $21: 61-66$.

Ministerie van WVC. Financieel Overzicht Zorg 1990. Den Haag, Staatsuitgeverij 1989.

Ministerie van WVC. Ouderenbeleid. Voortgangsrapportage 1982-1988. Den Haag, Staatsuitgeverij 1988.

Remmen JWM. Bejaardenoordbewoners of verpleeghuispatiënten? Hoogezand, Stubeg 1985.

SIG. SIVIS Jaarboek 1987. Utrecht, SIG 1988.

SIG. Gebruikershandboek SIVIS. Utrecht, SIG 1984.

Vink MT, Kam $P$ van der, Diesfeldt HFA. Gedragsproblemen in verzorgingstehuizen. Een inventarisatie in zes verzorgingstehuizen en een vergelijking met enkele verpleeghuizen. Tijdschrift voor Gerontologie en Geriatrie 1989; 20: 3-11.

Wierik MJM te, Frederiks CMA. Het verpleeghuis. In: Lath FL, Visser APh, Knipscheer CPM, Becker HA (red). Ouderen en ouder worden in maatschappelijk perspectief. Heerlen, Open Universiteit in druk.

Wierik MJM te, Frederiks CMA, Visser APh, Sturmans F. Verpleeghuisopname; een onderzoek bij op te nemen ouderen. Verschijnt in Tijdschrift voor Gerontologie en Geriatrie $1991 ; 22$. 


\section{HOOFDSTUK 8}

\section{DETERMINANTS OF THE OUTCOME OF NURSING HOME STAYS*}

Margreet JM te Wierik, Carla MA Frederiks, A Volovics, F Sturmans, APh Visser 


\section{Summary}

A one year prospective study among 157 nursing home patients was performed to investigate which admission characteristics are related to the outcome of the nursing home stay. After one year, $41 \%$ of the patients had died, $44 \%$ were still residents and only $15 \%$ were discharged home or to a home for the aged. The results of a polychotomous logistic regression analysis show that the functional status was associated with all outcomes, as could be expected. The number of diagnoses differentiated between being discharged and being deceased. Age and gender differentiated between still being a resident and being deceased: males and patients over 80 were more likely to die. The nature of the main diagnoses differentiated between being still resident and being deceased and between being discharged and being still resident: somatic patients were more likely either to die or to be discharged than psychogeriatric patients. The strain experienced by informal caregivers prior to the admission differentiated between being discharged and still being a resident, indicating that patients whose caregivers experienced more strain prilor to the admission were less likely to be discharged. For $54 \%$ of the patients, the observed outcome corresponded with the outcome predicted by the logistic regression model. Most mistakes were made by the madel in distinghuishing still resident patients from deceased patients and vice versa. A more precise measurement of the health and functional status of the patients might improve the prediction "as well as the inclusion of more of these variables. The same is true for the non-health variables. But, as non-health variables seem easier to manipulate than health variables, a further exploration of the social network and prior living arrangements is indicated, if ways are to be found to reduce the utilization of nursing homes.

\section{Samenvatting}

\section{Determinanten van de 'uitkomst' van verpleeghuisopnamen}

Om na te gaan welke opname-kenmerken gerelateerd zijn aan de 'uitkomst' van verpleeghuisopnamen, zijn 157 verpleeghuispa-tiënten tot 1 jaar na de opname gevolgd. $\mathrm{Na} 1$ jaar was $41 \%$ van de patiënten overleden, $44 \%$ was nog steeds opgenomen en slechts $15 \%$ was ontslagen naar huis of naar een verzorgingshuis. Uit een trichotome logistische regressie-analyse komt naar voren dat de functionele status bij opname, zoals verwacht, geassocieerd was met alle uitkomsten. Het aantal diagnosen differentieerde tussen overleden en ontslagen zijn. Leeftijd en geslacht differentieerde tuissen nog opgenomen en overleden zijn: mannen en patiënten ouder dan 80 jaar hadden meer kans om te overlijden. De aard van de hoofddiagnose differentieerde tussen nog opgenomen en overleden zijn en tussen ontslagen en nog opgenomen zijn: somatische patiënten hadden meer kans om of te overlijden of ontslagen te worden dan psychogeriatrische patiënten. De belasting die de informele zorgverleners voorafgaand aan de opname envaarden, differentieerde tussen ontslagen en nog opgenomen patiënten: indien de informele zorgverleners zwaarder belast waren, was de kans om ontslagen te worden kleiner. Het logistische regressie model voorspelde de "uitkomst' van de opname bij $54 \%$ van de patiënten correct. Het model ondervond vooral moeilijkheden bij het voorspellen welke patiënten na 1 jaar overleden dan wel nog opgenomen zouden zijn. De predictie kan mogelijk verbeterd worden door meer en/of gevoeliger maten voor de functionele status en de gezondheidstoestand te gebruiken. Hetzelfde geldt voor kenmerken als het sociale netwerk en de eerdere woonomstandigheden. Een verdere exploratie van met name deze kenmerken is aangewezen, wanneer het doel is manieren te vinden om het gebruik van verpleeghuizen te verminderen. 


\section{Introduction}

The present care for elderly people is under pressure; the growing numbers of elderly people, rising expenditures, and changing opinions on desirable circumstances for the ageing create the need for a reorganization of the care system. Reallocation of resources in favor of community care and at the expense of institutional care is seen as a realistic solution. As part of the institutional care, nursing homes provide the more specialized care. The patient population is heterogeneous and the length of stay shows a wide range (Liu and Manton 1983; Manton et al. 1985; Ribbe and Van Mens 1986; Frijters et al. 1987). If the use of nursing home bed days is to be reduced, longstay patients are the main target group for alternative care, such as residency in facilities with lower levels of care or remaining in the community with more care (Howe et al. 1986). They are the target group not only because they use the major part of resources but also because their need for specialized care is being questioned (Allison-Cooke 1982; Femmen 1985). Furthermore, nursing home care is especially appropriate for patients who are likely to remain in such a home for relatively short periods, either because of their high level of dependency or because they are receil ving restorative care prior to discharge (Howe et al. 1986). Within this framework, information on factors that are related to the outcome of nursing home care - discharge to the community or death in the short term on the one hand, and long stays on the other - is important, as it might lead to a more efficient allocation of care.

In Maastricht, a town in the south of the Netherlands (116.000 inhabitants), a 1 year prospective study among newly admitted nursing home patients was performed to investigate which factors determine the outcome of nursing home stays. In nursing homes in the Netherlands, the emphasis is on nursing and medical care. According to the objective of the admission, patients can be differentiated into terminal patients, rehabilitation patients and chronic somatic and psychogeriatric patients. Patients are admitted to either a somatic or a psychogeriatric ward; medical care is received from nursing home physicians. The stays are financed by a state-organized health insurance scheme and by income-linked contributions from the patients. About $90 \%$ of the nursing home population are 65 or over (Mimisterie van WVC 1990). In 1987, as many as $2.5 \%$ of the elderly people (65 years and over) resided in nursing homes (Huijsman and Rutten 1989).

This paper addresses itself to the question which admission characteristics of nursing home patients are related to the outcome of nursing home stays. Before the methods used are described and the results are presented, previous research regarding this subject is discussed.

\section{Previous research}

Patient characteristics related to the outcome of nursing home care have been investigated by various researchers in different ways. The study designs (longitudinal and cross-sectional), outcome measures (long-stay versus short-stay or discharge status), characteristics included in the studies, health care settings (organization and financing) as well as methods of analysis have differed. As different results are at least partly the result of these differences, a direct comparison of the results of the various studies is not feasible.

Therefore, the findings have been summarized for each characteristic in table 1. It should be mentioned that some of the factors appear so much a matter of course that it seems unnecessary to study them. It should be stressed, however, that these very plausible factors are sometimes not identified as related to the outcome of the 
nursing home stay. This might be due to the fact that they were simply not included, but also to the fact that they are too closely related, for instance gender and marital status. Older women are mostly widowed; males are more often (still) married.

Table 1. Studfice by warious authon and the factors they mention as related to nursing home dischargle status

\begin{tabular}{|c|c|}
\hline AUTHOFB (WH & COWPAPISON \\
\hline Diestefter (rig) & admiesion characterilstics of psychogeriatric peatients who die within 1 year veirsus those who survive \\
\hline Oiarriard ent al. (90) & admission characterilstics of newly admittiod patients with different outcomes after 1 year \\
\hline Varit den Haw $(\mathrm{m})$ & characteristics of nursing home residents who died within one year versus those who survived \\
\hline Jecolbs at all. (78) & $\begin{array}{l}\text { degree of functional dependency "/a year atter admizsion of psycho-geriatrie patients who died within } \\
\text { one year varsus those who survived }\end{array}$ \\
\hline Kante at al. (83) & characteristics of receritly admittod pathents with different outcomes \\
\hline Keveler at at. $(81)$ & short-btayoro wereus long-stayors \\
\hline Loswis al (a5) & admission characteristics of patients with ditferent discharge status. \\
\hline Lowis ot al. $(89)$ & adfmission characteristics of patients coming from homo or hospital with different diseharge status \\
\hline Lowis of al. $(90)$ & admiseion characteristics of readmitted patients transferred from hospitals with different outcomes \\
\hline Hitchtengtoin et al. (85) & $\begin{array}{l}\text { nursing horre patients who died within one year versus matchend patients surviving at least } 4 \text { to } 5 \\
\text { yoars }\end{array}$ \\
\hline Liu \& Manton $(83)$ & end-of-year discharged versus pesident patients of a 1 year admission cohort \\
\hline Liu \& Manton (84) & characteristics of patients at discharge of a 'synthetic' addmission colnort with different outcomes \\
\hline Morkus $(74)$ & admission characteristics of patiants with different outcomes, yoar after admission \\
\hline Rattininas Garrity (86) & community dischargas versus discharga to other nursing homes and death \\
\hline Shapiro \& Wobster (84) & mortality rates of successive nursing home admisstion coharts \\
\hline Spence \& wioner (ool) & characteristies of short- and long-stayers (based on aggregatimg prior nursing home stays) \\
\hline Weissert \& Scanton (BS) & community discharges versus unfavourable discharges and death \\
\hline
\end{tabular}

\section{RESULTS PER FACTOA IMPACT ON NUASING HOME DISCHARGE STATUS}

\section{AGE}

Diesteldt 79 )

Gerrard of al. 190 )

Van dor Hauval $(7)$

Kalne ot al. (B3)

Kaolar at al (B.1)

Lowis ot al. (209)

Lowis at al. (20)

Woiscert sciamiom (85)

\section{MARTTAL STATUS}

Garrard at al. (90)

Van den Houval (7m)

Kew ler of al. (81)

Lawis of al. (90)

Liu Manton (83)

Spence \& Whenor (90)

Weissert \& Scanilon (a5) older pationts were moro likely to die within 1 year alter admission

oldar patients were more likely to have diad after one year; younger patients were more lik ly to be diseharged to the community

oldar residents were more likely to die

older patients wera somewhat less likely to lis we the home, especially to go into hospittal short-stayers wer lass otten over 85 than llong-stayers

patimants aged 75 and over were more likely to die but less fikely to be transferred to hospitals pationte aged 75 and ower were more likely to die

older pationts were less often discharged to the community

patients wilh a spouse were more likely to be discharged to the community marpiad rasidients wore mere likely to die. short-stayers were more often marrled thath long-stayers married patients were more likely to retum home matried parsons wore more oftan discharged alive short-stayers were somewhat more likely to be married being married increased the probability of commurity discharge 


\section{GENDEF:}

\section{Diestiondt (79)}

Keeler at. (a)

Lewis at al. (BS)

Spence Wiener (90)

SOLIRCE OF PAYMENT

Garrard at al. (9O)

Keeler of (8)

Lewis et al. (85)

Liv \& Manton (83)

\section{LWINIG ARRANGEMENTS}

Kegler et al. (8i)

Lawis et al. (89)
Merkus (74)

Weissert \& Scanton 185

men were more lkkely to die within 1 yaan after admission shot-steyly rs wor more likely to bo males

women were more likely to raturn to the commumity: males were more likety to be trensterted to a mospital

the situaton $1 /$ y year after admision was more favourablo for women

shourt-stayers were somewhat more likely to be mate

medicere patients ware mone likely to be discharged to the communty

Hong-stuy were mostly supported by medicaid

If discherged alive, self-pay patients were mor likely to live in the communithen thethery nursing homes

medlcare patichts were mostly discharged aliwe lin the game year

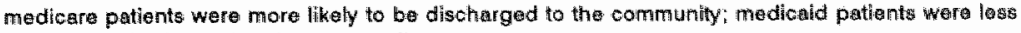
likely to be discherged to the community

\section{RIOA TO ADMISSION}

short-stayers came mostly from a hospital, long-stayars often came from priwate residences on other facilitilios

prior liwing arrangements (home versus hospitaly had an affect only in interaction with readmiaslory itatus (soo belowi)

\section{PREVIIUS NURSING HOME STAY}

Lowis ot al. $(89)$

being a mursing home read mission was associatod negativelly with returning home and positivelly with discharge to a hospital there was strong interactiom botweon prior location (home ve hosplitil) and readmission statis. For patients admitted from home the effect of readmisislom status was negligible; for those adritted from hospital there was a megative effect

Spence \& Wiener $(90)$

short-stayens were somewhat more likely to hawe beren through provious mursing homio stays

\section{SOCLAL SUPPORT}

Wan den Heuwel (T7)

Merkusi (74)

Rewvisis at all. (85)

rosidents with a batter sooilal networks were more likely to die

the situation $1 / 2$ year after admission was more favourable for patients livimg alone prior to mamissilor patients who received visits from friends and family were more likely to be discharged alivo

\section{DISCHARGE PROGNOSHS AT ADMISSION}

Kare al. (83)

Reilsimas Q Garrity (B6)

clinical prognoses on future functioning were significant predictors of status changes (discharged to the community and death were predicted best)

Diosfuldt $(79)$

Gerrard at al (90)

Weir den Metavell (77)

Jacobs at al. (PB)

Kane et ali, (83)

Kever ot all. (B1)

Lowis ot al. (85)

Lewis mat al. (89)

Lew ot al. (90)

Lichtenstein ot all. (85) discharge prognosis at admiswion was the only otrong predictor of return to the commonity

pation who were more helplass were moro lilkoly to dio

pationts not cognitively impaired were mare liskely to be chischargod to the oommunity

residents whose ADL functione declinod trom admiosion more more likely to die

pationtes who were more dopandent were more likely to die

only few limitations in cognition and ADL were positively relatod to buing cllacharged withli 3 momtlingi

bodtest pationtls wore almost all short-stayors

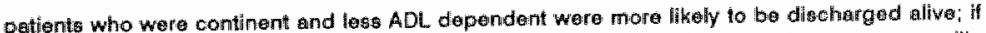
discharged aliwe, patients who were continent, oriented and loss ADL deperident, wore mope likoly to bo liwing in the community than in (othor) nursing homast

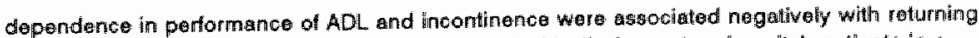
homer uncontinence was also positively associated with discharge to hospitat; patlentig int a comallose stata were more likely to die but lass likely to be trangfarred to hospinals to bed increased the change of dying and decreased the chmes of returning home; dependance in

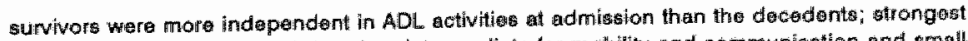
associations tor bathing and drossing intermediete for mobility and cominuritication and amallest for incomtinence

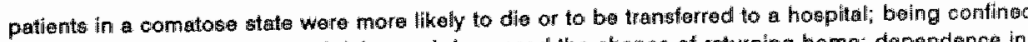
pertomanco of ADL and incontinence were also negatively essociatod with roturming horme. 
Lis

LW

Werkine 04

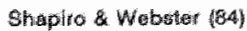

Weigent \& Lanlon (Bg) DHARNOSES

Carrard ott w. (90)

Karre ot at, (83)

Kegler ot al. (B)

Lewhis ot al. (95)

Lewic of

Liu \& Manton (B3)

Lilu \& Manton (B4)

Markus (74)

Waissert \& Scanton (85)

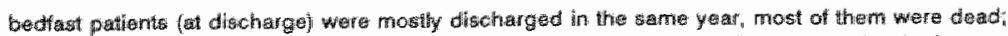

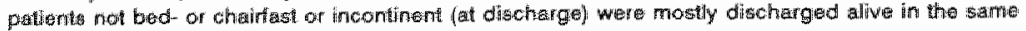
your

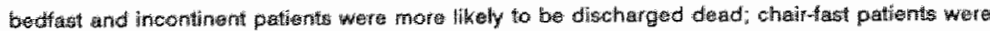

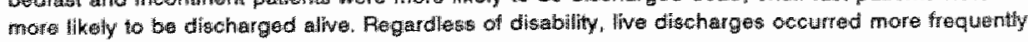

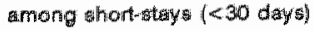

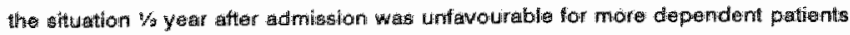

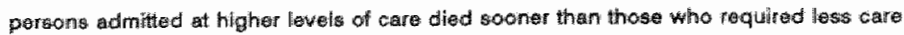

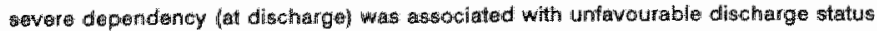

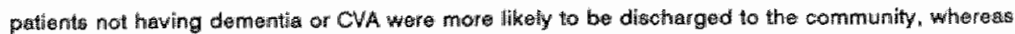

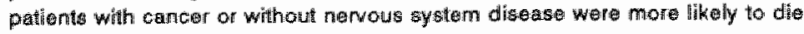

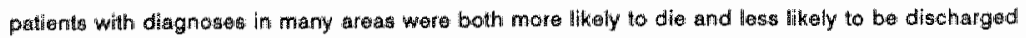
to 1 ho community

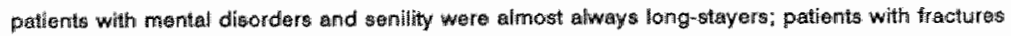
and cancer wer mostly shortastay ars

if discharged a (other) nursing homes

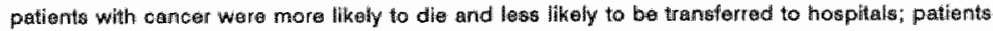
with hip fractures also were les ollikely to be transforred to haspitals

cancer patients wore usually discharged in the same yaar, either death or aliwe; thip fracture patients were mosily disicharged alive in the same year

patients wh hip tractures ware most lingly to be discharged alve, followed by stroke and chromic

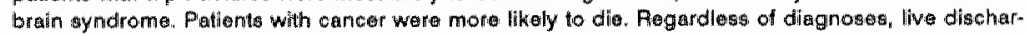
ges occurred more trieguently amang short-shays ( $<30$ daysi)

the situdion $1 / 2$ your after admission was unfavourable for patients with cancer or mental disorders

patients with 4 rectures were more likely to be discharged the community: stroke, cancar and mental disorders decreased the probability of community discharge

The review of the literature shows that the functional status has been most consistently found to be related to the outcome of nursing home stays. Diagnoses have also been found by several researchers to be related to outcome, but the findings regarding the influence of specific diagnoses are less consistent, with the exception of cancer. The same is true for the demographic variable gender. It has been found to be associated with outcome several times, but the findings are not quite consistent. The influence of age and marital status is fairly clear: younger and married patients were found to have more favourable outcomes. The findings regarding prior living arrangements and social support are not consistent. Besides, these factors, as well as discharge prognosis at admission and previous nursing home admission either have not often been found to be associated with outcome or were not investigated. Social support in particular has not often been investigated, which as such is striking. As social support is known to be a determinant of the use of institutional care (Colerick and George 1986; Evashwick et al. 1984; Smyer 1980; Tobin and Kulys 1981), it is plausible that it is associated with the outcome of institutional care as well.

The present study differs from previous research in several respects. First, it is a Dutch study, implying that the source of payment of the nursing home stay does not need to be considered, since in the Netherlands the stay is universally insured. It further means that transfer to a hospital as an outcome category is not under discussion. Whereas in, for instance, the U.S.A. about one third of the nursing home stays ends with a transfer to a hospital (Kane and Kane 1989), nursing home stays in the Netherlands hardly ever result in hospital admissions, which is probably due to different policies. Nationally, about $7 \%$ of all definite discharges are transfers to a hospital (SIG 1989). In the present study, in 1 year, $2 \%$ of the patients were transferred to a 
hospital, and because they all died there within 1 week, they were classified as deceased. Finally, the social network of the patients, including the strain experienced by their caregivers prior to the admission, is explicitly taken into account.

\section{Methods and subjects}

A longitudinal design was chosen, in which patients to be admitted to a nursing home were followed for up to one year after admission. The assumption was that within one year, the actual rehabilitation patients would have been discharged and that those not discharged or deceased after one year would become longl-stayers. The study among 157 nursing home applicants (55 years and over) was performed in Maastricht during the period February 1987 until July 1989. Nursing home applicants in need of terminal care were excluded. For privacy reasons, social workers of the two nursing homes in Maastricht first contacted the nursing home applicants or an informal caregiver during the intake, and asked them whether they were willing to participate in the study. The social workers indicated that they found it hard and conflicting with the aim of the intake to ask for participation, especially in complex admissions. In all, about half of the considered group of nursing home applicants were forwarded to the study, of whom $80 \%$ participated. The main reasons for the $20 \%$ non-response were that the situation surrounding the admission was too difficult or that the health of the caregiver was too poor to allow an interview. Of the 157 participating applicants, 130 had an informal caregiver, of whom 127 were interviewed. Information from the nursing home physicians in charge was obtained for all applicants. The reasons for not forwarding or responding indicate that nursing home patients with complex home situations are underrepresented in the study population. Comparison with national figures, however, showed that the participants were at least as disabled as recently admitted nursing home patients in general ( $\mathrm{Te}$ Wierik et al. 1991), which as such is reassuring for the generalizability of our findings. The data were gathered in three ways. First, structured interviews were held with the applicants or with a second respondent, usually an informal caregiver, in order to obtain information on financial status, prior living arrangements, and social network. Second, informal caregivers, when available, were interviewed, again by means of a structured questionnaire, in order to inventory, among other things, the strain they experienced. The informal caregivers and/or the applicants were interviewed by trained interviewers and, as much as possible, before the actual admission took place. Finally, shortly after the admission, the nursing home physicians in charge completed a written questionnaire on the functional status, diagnoses and admission related characteristics, using the classifications of the SIVIS nursing home registration system (SIG 1984). Table 2 provides the investigated concepts, with their operationalizations and, where applicable, technical information on the scales used.

In cases where the nursing home admission was preceded by an admission to a hospital or other health care facility, the questions on the social network were asked with regard to the period before these admissions.

The data were analyzed in two ways. A bivariate analysis was performed to inventory associations of individual admission characteristics with the outcome of the nursing home stay. In addition, a logistic regression analysis was executed to study the associations between the outcome and individual characteristics while controlling for others. For this purpose the BMDP polychotomous logistic regression was used (Dixon et all. 1990). This program makes all possible comparisons between the outcomes simultaneously. 


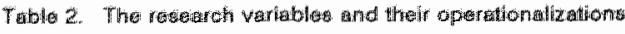

\begin{tabular}{|c|c|}
\hline CHRARACTERTSTC & OPEFHTOLHALATIOR \\
\hline
\end{tabular}

EXPLANATION

(scores and Cronbach's a)

Demographic variablec

\begin{tabular}{|c|c|}
\hline A & Agro fin years \\
\hline Gorted & Eviderit' \\
\hline Fingmelgi statuse & Pircoñu sutfielency of financial mean \\
\hline 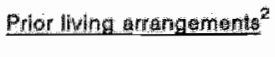 & 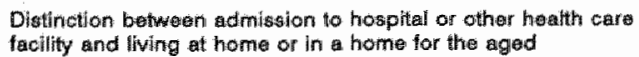 \\
\hline
\end{tabular}

\section{Sociall networth}

Howeshold composition ${ }^{2}$ The way the howsuhoid and Iwing were arranged

Whatg rectivad

Stretin experienoed by informal caregiver ${ }^{3}$

The number af wiste the olderly person sacived per month prior to the admigstion

Col scote = the sum of positive artswers to the questions of a Iranstaled version of the Caragiver Strain Index (Fobinson 1983;

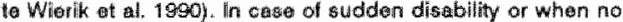
Aniormal caregiver was present, a score of zero was giwern

\section{Admition ron rated oharactoristic}

Objactiwe of

the adionision

Dischargo prognosis atit.

\section{Functional status}

Bolnawior

Conted functions

ADL

Mobility

Conthónce

Total ationability

\section{Dhanosgen}

Madicall comploxity

Nature of the main disanosis

Wain disgnosis

Distinction whether the objective of the admisision is continucus support, rehabilitation or otharwise

Assessment al admission whather a patient is most likely to have died, to be silll resident or to bo discharged home or to a home for the aged one yoar after admission

Whather or not ward bohavior is disturbing

Contact score = the sum of problems with hearing and active and passảve communication (in word, writting or gesticulation)

ADL score = the sum of 5 ADL activities (toileting, feeding, getting drased, whathing upper and lower pant of the body which canmot bo portornod independently

Mobillty score sin the sum of problems with 4 mobility items loetting in and out of bud, walking, standing, powel of enduramea (mone warsus lass than 6 hours a day out of bad)

Continence score = the sum of being incominent for urine and Iates

Disability score whe sum of bahavior contact, ADL, mobility, and contimance scoras $0=\sin 80 ; \quad \|=80+$

$0=$ male: $1=$ fomale

$0=$ suffichent; $1=$ insufficitent:

$0=$ own hame or home for the sged:

$1=$ hompital or other facillity

O $=$ living alone:

$1=$ living with others

0-13: the higher the more strain: $=0.74$
$0=$ not disturbing:
$1=$ disiturbing

0-3. the higher the more contact problems; $\alpha=0.73$

0.5" thin thigher the more impained; $=0.71$

Q4: the higher the more impainad; $a=0.80$

0.2: the highor the more impaired; $=0.63$

0.15: the higher the mor impaired; 0.83

$1-3$

$0=$ somatic:

$1=$ psychogeriatric

1 unformation obtained from the nursing home physiciens in charge

2 information obtained from the pationts themselves or from their informal caregivers

3. information obtained from informal caregivars 


\section{Results}

\section{Bivariate anallysis}

Within one year after admission, only 23 patients (15\%) had been discharged home or to a home for the aged, and 64 patients $(41 \%)$ had died; 70 patients (44\%) were still residents after one year. In table 3 the distributions of the inventoried characteristics are presented for each outcome of the nursing home stay. It shows that demographic variables, financial means, and prior living arrangements did not differ significantly for the various outcomes of the nursing home stay. The same holds for the characteristics of the social network, with the exception of the CSI score: caregivers of the patients still resident after one year experienced more strain prior to the admission than those of the discharged patients. Admission related characteristics and functional status differed significantly between outcomes. Patients admitted for continuous support were either still resident or deceased after one year; they were hardly ever discharged.

Patients whose prognosis at admission was that they would be discharged after one year were indeed more often discharged than still resident or deceased. Of the patients with the prognosis that they would still be resident after one year, about half were indeed still resident, but $45 \%$ of them had died. With regard to functional status, the deceased patients were 'worst off' on all aspects of the functional status at admission, except for behavior and contact, which were slightly more problematic for the still resident patients. By contrast, the discharged patients were 'best off' regarding these admission characteristics. Finally, as far as diagnoses are concerned, the number of diagnoses did not differ, whereas the nature of the main diagnosis did. Almost all discharged patients had a somatic main diagnosis. Psychogeriatric main diagnoses were most prevalent among the still resident patients, which is also shown by the specification of the main diagnosis.

Thus, several individual admission characteristics appear to be associated with the outcome of the nursing home stay. But, since many of the admission characteristics are interrelated, a problem for which a bivariate analysis cannot control, a multivariate analysis, in the form of a polychotomous logistic regression analysis, was also performed. To give some idea of the interrelatedness among the admission characteristics, their correlation matrix is presented in table 4.

\section{Logistic regression analysis}

Logistic regression analysis can more precisely identify the association of individual characteristics with the outcome of the nursing home stay. The outcome of the nursing home stay was the trichotomous, dependent variable. A selection of the inventoried admission characteristics was made by choosing only one out of two or more strongly interrelated characteristics to be entered into the model. In this way, a reasonable number of independent variables in relation to the number of cases in each outcome category was obtained and strong associations between independent variables were avoided. So, instead of using the five separate aspects of the functional status, the total disability score was used as an independent variable. Furthermore, the objective of the admission and the discharge prognosis at admission were left out of the analysis. They were not only strongly interrelated but also strongly associated with various aspects of the functional status and with the nature of the main diagnoses (see table 4). Age and prior living arrangements were dichotomized. 


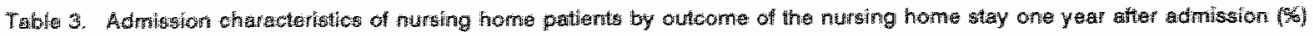

\begin{tabular}{|c|c|c|c|c|c|c|}
\hline 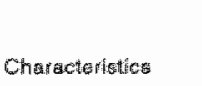 & & $\begin{array}{l}\text { Tetal } \\
(n=15 n)\end{array}$ & $\begin{array}{l}(1) \\
b e c 060 d \\
(m=64)\end{array}$ & $\begin{array}{l}\text { Stil }(z) \\
\text { Roside } \\
(n=70)\end{array}$ & $\begin{array}{l}\text { (3) } \\
\text { Dischargend } \\
(n=23)\end{array}$ & 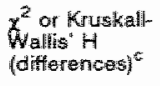 \\
\hline \multicolumn{7}{|c|}{ 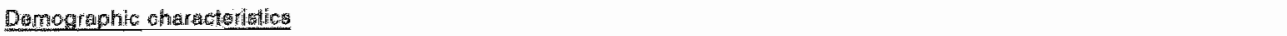 } \\
\hline A696 & $\begin{array}{l}55-64 \\
65 \times 74 \\
75-84 \\
85+4\end{array}$ & $\begin{array}{r}8 \\
73 \\
73 \\
43\end{array}$ & $\begin{array}{rr}3 & (38) \\
14 & 42) \\
27 & 37 \\
20 & (46)\end{array}$ & $\begin{array}{r}4 \\
10 \\
39 \\
39 \\
17\end{array}$ & $\begin{array}{ll}1 & (12) \\
9 & (27) \\
7 & (10) \\
6 & (14)\end{array}$ & $\begin{array}{l}H=4.5 \\
m .5\end{array}$ \\
\hline Gandor & $\begin{array}{l}\text { mollo } \\
\text { figtrolo }\end{array}$ & $\begin{array}{r}49 \\
108\end{array}$ & $\begin{array}{l}20(53) \\
30(35)\end{array}$ & 164 & $\begin{array}{r}7(14) \\
46(15)\end{array}$ & $\begin{array}{l}y^{2}=4.9 \\
7.5\end{array}$ \\
\hline Financial means & 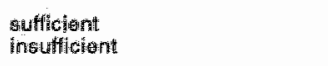 & $\begin{array}{r}120 \\
24\end{array}$ & $\begin{aligned} 54 & (44) \\
5 & (24)\end{aligned}$ & 55 & $\begin{array}{r}14(11) \\
6(28)\end{array}$ & $\begin{array}{l}x^{2}=5.5 \\
\text { h.s. }\end{array}$ \\
\hline 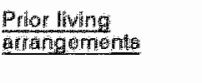 & $\begin{array}{l}\text { owm home: } \\
\text { home for the agad } \\
\text { notpital }\end{array}$ & $\begin{array}{l}47 \\
31 \\
79\end{array}$ & $\begin{array}{ll}20 & (42) \\
16 & (52) \\
28 & (35)\end{array}$ & $\begin{array}{l}20(42 \\
14,45) \\
30(46)\end{array}$ & $\begin{array}{rr}7 & (15) \\
1 & (3) \\
15 & (19)\end{array}$ & $\begin{array}{l}x^{22}=5.3 \\
m .5 .\end{array}$ \\
\hline \multicolumn{7}{|l|}{ Soctal notworth } \\
\hline $\begin{array}{l}\text { Howsohold } \\
\text { compositon }\end{array}$ & $\begin{array}{l}\text { alone } \\
\text { whth others }\end{array}$ & $\begin{array}{l}87 \\
70\end{array}$ & $\left.\begin{array}{ll}34 & (39) \\
30 & 43\end{array}\right)$ & $\begin{array}{l}4248 \\
28\end{array}$ & $\begin{array}{l}11(13) \\
12(17)\end{array}$ & $\begin{array}{l}x^{2}=1.3 \\
\text { m.s. }\end{array}$ \\
\hline $\begin{array}{l}\text { Wisitim } \\
\text { lectwet }\end{array}$ & $\begin{array}{l}0-5 \\
6-30 \\
31+\end{array}$ & $\begin{array}{r}8 \\
63\end{array}$ & $\begin{array}{r}1(1,2) \\
29 \\
33(46)\end{array}$ & $\begin{array}{ll}7 & 684 \\
27 & 43 \\
35 & 42\end{array}$ & $\begin{array}{l}\overline{7} \\
16\end{array}(19)$ & $\begin{array}{l}H=9.2 \\
\text { m.s. }\end{array}$ \\
\hline Collseores & $\begin{array}{l}0.4 \\
5-8 \\
9-13\end{array}$ & $\begin{array}{l}55 \\
52 \\
47\end{array}$ & $\begin{array}{l}23(42) \\
24(46) \\
16(34)\end{array}$ & $\begin{array}{ll}20 & 36) \\
22 & (42) \\
27 & (57)\end{array}$ & $\begin{array}{r}12(22) \\
6 \\
4\end{array}\left(\begin{array}{l}12) \\
9\end{array}\right)$ & $\begin{array}{l}H=7.9 * \\
(2-3)\end{array}$ \\
\hline \multicolumn{7}{|c|}{ Admigolor relatod ondracteristics } \\
\hline $\begin{array}{l}\text { Oldatediwa of } \\
\text { admigsion }\end{array}$ & $\begin{array}{l}\text { continuous support } \\
\text { rabrabilitation } \\
\text { othenwise }\end{array}$ & $\begin{array}{l}84 \\
55 \\
17\end{array}$ & $\begin{array}{r}39(46) \\
16 \\
9(29)\end{array}$ & $\begin{array}{ll}43 & (511) \\
22 & (40) \\
4 & (23)\end{array}$ & $\begin{array}{r}2 \\
17 \\
4\end{array}\left(\begin{array}{r}2 \\
(23)\end{array}\right)$ & $x^{2}=252^{* *}$ \\
\hline $\begin{array}{l}\text { Digcharge } \\
\text { prograosos at } \\
\text { admission }\end{array}$ & $\begin{array}{l}\text { deceased } \\
\text { still rosidont } \\
\text { discharged }\end{array}$ & $\begin{array}{r}9 \\
93 \\
47\end{array}$ & $\begin{array}{ll}8 & (89) \\
42 & (45) \\
11 & (23)\end{array}$ & $\begin{array}{r}111) \\
49 \\
95(33)\end{array}$ & $2\left(\begin{array}{c}2 \\
21\end{array}\right.$ & $\begin{array}{l}H=31.1^{*} \\
(1-3 / 2-3)\end{array}$ \\
\hline \multicolumn{7}{|l|}{ Furctional status } \\
\hline Bohawior & $\begin{array}{l}\text { rot disturbing } \\
\text { disturbing }\end{array}$ & $\begin{array}{l}79 \\
78\end{array}$ & $\begin{array}{l}30(38) \\
34(44)\end{array}$ & $\begin{array}{ll}28 & (35) \\
42 & (54)\end{array}$ & $\begin{array}{r}21 \\
2\end{array}(27)$ & $\begin{array}{l}H=18.6 \\
H-3(2-3)\end{array}$ \\
\hline $\begin{array}{l}\text { Contuet } \\
\text { seore }\end{array}$ & $\begin{array}{l}0 \\
1.2\end{array}$ & $\begin{array}{l}50 \\
65 \\
30\end{array}$ & $\begin{array}{ll}21 & (36) \\
28 & 43) \\
14 & 47\end{array}$ & $\begin{array}{ll}18 & (30) \\
35 & (54) \\
15 & (50)\end{array}$ & $\begin{array}{r}20 \\
2 \\
1\end{array}\left(\begin{array}{l}34 \\
3\end{array}\right)$ & $\begin{array}{l}H=22.2^{n k} \\
(1-3(2-3)\end{array}$ \\
\hline ADL $\operatorname{sincora}$ & $\begin{array}{l}03 \\
4 \\
5\end{array}$ & $\begin{array}{l}28 \\
60 \\
60\end{array}$ & $\begin{array}{r}5(18) \\
19(32) \\
39(57)\end{array}$ & $\begin{array}{ll}12 & (43) \\
30 & (50) \\
28 & (41)\end{array}$ & $\begin{array}{r}11(39) \\
11\left(\begin{array}{c}(8) \\
1\end{array}\right)\end{array}$ & $\begin{array}{l}H=29.7^{*} \\
(H-2 / 1-3 / 2-3)\end{array}$ \\
\hline $\begin{array}{l}\text { Mobility } \\
\text { acor }\end{array}$ & $\begin{array}{l}0-1 \\
2-3 \\
4\end{array}$ & $\begin{array}{l}50 \\
52 \\
25\end{array}$ & $\begin{array}{l}11(22) \\
36 \\
17(44)\end{array}$ & $\begin{array}{rr}31 & (62) \\
32 & (39) \\
7 & (28)\end{array}$ & $\begin{array}{r}8 \\
14(17) \\
1\end{array}$ & $\begin{array}{l}H=18.4 * \\
(1-2(\pi-3)\end{array}$ \\
\hline $\begin{array}{l}\text { Continano } \\
\text { acoro }\end{array}$ & $\begin{array}{l}0 \\
1 \\
2\end{array}$ & $\begin{array}{l}63 \\
43 \\
51\end{array}$ & $\begin{array}{ll}16 & (25) \\
23 & (5.4) \\
25 & (49)\end{array}$ & $\begin{array}{l}29(46) \\
16 \\
25(49)\end{array}$ & $\begin{array}{rr}18 & (29 \\
4 & 9 \\
1 & (2)\end{array}$ & $\begin{array}{l}\mathrm{H}=18.5 * \\
(1-3 / 2-3)\end{array}$ \\
\hline $\begin{array}{l}\text { Disability } \\
\text { scoro }\end{array}$ & $\begin{array}{r}07 \\
8-9 \\
10-12 \\
13-15\end{array}$ & $\begin{array}{l}47 \\
38 \\
37 \\
35\end{array}$ & $\begin{array}{rr}9 & (19) \\
14 & (37) \\
19 & (51) \\
22 & (63)\end{array}$ & $\begin{array}{l}22(47) \\
18(47) \\
17(46) \\
13(37)\end{array}$ & $\begin{array}{r}16 \\
6 \\
1\end{array}\left(\begin{array}{l}16 \\
-3\end{array}\right)$ & $\begin{array}{l}H=30.9)^{*} \\
(1-2 / \pi-3 / 2-3)\end{array}$ \\
\hline \multicolumn{7}{|l|}{ 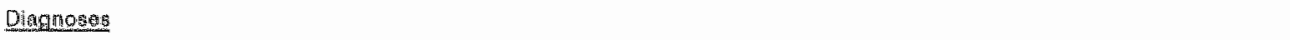 } \\
\hline $\begin{array}{l}\text { Numbot of } \\
\text { dikgnosogs }\end{array}$ & $\begin{array}{l}1 \\
2 \\
3\end{array}$ & $\begin{array}{l}29 \\
63 \\
68\end{array}$ & $\begin{array}{r}63) \\
26(41) \\
32(47)\end{array}$ & $\begin{array}{l}12(46) \\
31(49) \\
27(40)\end{array}$ & $\begin{array}{l}8(3) \\
6(10) \\
9(13)\end{array}$ & $\begin{array}{l}n=4.1 \\
n . s .\end{array}$ \\
\hline $\begin{array}{l}\text { Mature of } \\
\text { main dilagrosig }\end{array}$ & $\begin{array}{l}\text { somalic } \\
\text { psychogoriatrlo }\end{array}$ & $\begin{array}{r}102 \\
55\end{array}$ & $\begin{array}{ll}43 & (42) \\
21 & (38)\end{array}$ & $\begin{array}{l}37(36) \\
33(001)\end{array}$ & $\frac{22}{1}(2)$ & $x^{2}=4.2 \times 14$ \\
\hline $\begin{array}{l}\text { Main } \\
\text { diagriogis }\end{array}$ & 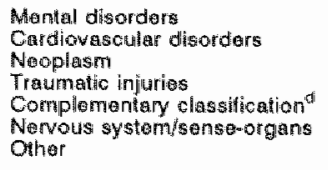 & $\begin{array}{r}55 \\
43 \\
13 \\
13 \\
8 \\
8 \\
17\end{array}$ & $\begin{array}{cc}21 & (38) \\
18 & (42) \\
11 & (85) \\
3 & (23) \\
1 & (12) \\
2 & (25) \\
8 & (47)\end{array}$ & $\begin{array}{rr}33 & (60) \\
16 & (37) \\
2 & (15) \\
5 & (38) \\
3 & (38) \\
4 & (50) \\
7 & (41)\end{array}$ & $\begin{array}{l}1(2) \\
9(21) \\
-5 \\
5(38) \\
4(50) \\
2(25) \\
2(12)\end{array}$ & \\
\hline
\end{tabular}

a Tha deceasad peatlents include 3 patients who were transterred to a hospital and dived there within one weelk. b Discharged means discharged home of discharged to a home for the agect.

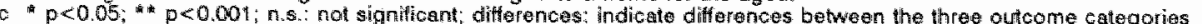

d This category inciludes, among of her things, stitus after hip surgery, amputation status and other status after surgery. 
Table 4 . Correlation matrix of the admission eneracteristios"

\begin{tabular}{|c|c|c|c|c|c|c|c|c|c|c|c|c|c|c|c|c|c|c|c|}
\hline & 1 & 2 & 3 & $4 a$ & $4 b$ & 5 & 6 & 7 & 8 & Bb & 9 & 10 & 11 & 12 & 13 & 14 & 15 & 16 & 17 \\
\hline A Age & H & & & & & & & & & & & & & & & & & & \\
\hline 2 Gender & - & $i$ & & & & & & & & & & & & & & & & & \\
\hline $\begin{array}{l}\text { 3. Finuancial means } \\
\text { 4. Prior tiving } \\
\text { arrangements }\end{array}$ & -28 & - & $i$ & & & & & & & & & & & & & & & & \\
\hline a home for the aged & 25 & - & - & 1 & & & & & & & & & & & & & & & \\
\hline $\begin{array}{l}\text { b hospital } \\
5 \text { Household }\end{array}$ & - & - & . & -.50 & 1 & & & & & & & & & & & & & & \\
\hline compositton & -2.2 & -20 & - & -.35 & - & 1 & & & & & & & & & & & & & \\
\hline S Wisilts recoived & - & - & - & -.30 & - & .25 & 1 & & & & & & & & & & & & \\
\hline $\begin{array}{l}7 \mathrm{CSI} \text { score } \\
8 \mathrm{~d} \text { dmission objective }\end{array}$ & - & * & $\cdot$ & - & -.119 & - & * & 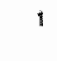 & & & & & & & & & & & \\
\hline continulous support & .19 & $\cdot$ & - & .27 & - & - & - & - & 1 & & & & & & & & & & \\
\hline b rehabilititaition & * & - & - & -.27 & .20 & - & - & - & -.80 & 1 & & & & & & & & & \\
\hline 9 Discharge prognosis & - & - & 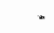 & -.23 & .18 & - & - & - &. .58 & .67 & 1 & & & & & & & & \\
\hline 10 Bethavior & - & - & - & - & -.21 & - & - & .19 & .63 & -.51 & -.38 & 1 & & & & & & & \\
\hline 11 Contact & .18 & - & - & .26 & -.16 & - & - & - & 65 &. .54 & -.53 & .61 & 1 & & & & & & \\
\hline $12 \mathrm{ADL}$ & .20 & - & - & • & - & - & * & - & .35 & -.17 & .41 & .27 & .42 & 1 & & & & & \\
\hline 13 Mobility & .17 & - & - & - & .16 & - & - & -.16 & $\therefore$ & - & - & -16 & - & 57 & 1 & & & & \\
\hline 14 Continence & • & - & - & .25 & -.24 & - & - & - & .52 & -.37 & -.36 & .43 & .58 & .50 & 21 & $\pi$ & & & \\
\hline $\begin{array}{l}\text { 15. Disiability } \\
16 . \text { Number of }\end{array}$ & .23 & - & - & .19 & - & . & - & * & .55 & -.37 & .49 & .48 & .71 & .85 & .64 & .75 & 1 & & \\
\hline $\begin{array}{l}\text { diagnoses } \\
17 \text { Nature of }\end{array}$ & * & - & -.22 & * & - & * & - & - & - & . & - & - & - & - & .16 & - & - & 1 & \\
\hline main diagnosis & * & - & - & .27 & -.26 & - & $\therefore$ & .23 & .58 & -.49 & -.29 & .55 & .51 & - & -.25 & .37 & .28 & -.16 & 1 \\
\hline
\end{tabular}

1 Correllations are presented only if $r>10.15$

Dumny variables, indicated by and $b$, were usied for the mominal variablas with 3 oategories.

Thus, the independent variables entered into the model were: age, gender, financial means, prior living arrangements, household composition, visits received, CSI score, disability score, number of diagnoses and nature of the main diagnosis. The analysis was performed with the variables coded as indicated in table 2. Given the barely adequate ratio of cells to respondents, only one logistic regression model, including all mentioned variables as coded, was fitted to the data. The fit, judging by residuals and case diagnostics, was reasonable. The results are presented in table 5, which shows that the disability score is associated significantly with all outcomes and that most of the other characteristics are associated significantly with one or two outcomes. Three characteristics, viz. prior living arrangements, household composition, and the number of visits received, did not show any influence on outcome.

The exponent of the coefficient (the fourth column of table 5) is the Odds Ratio (OR). which estimates the association of the given outcome with a given admission characteristic, keeping other variables fixed. For a dichotomous variable, the OR indicates that the odds of one outcome versus another is greater or smaller for a patient with the admission characteristic than for one without (other things being equal). For instance, the odds of being still resident to being deceased after one year is 2.6 times greater for a patient with a psychogeriatric main diagnosis than for a patient with a somatic main diagnosis. For a continuous or interval variable, the $\mathrm{OR}$ is the change in relative odds of one outcome versus another resulting from a one unit change in the variable (other things being equal). It is, however, more informative to compare two, more contrasting, values of the continuous variable, using the formula: $O R_{x_{2} x_{1}}=$ exp [coefficient $\left(X_{2}-X_{1}\right)$ ]. For instance, when comparing discharged patients with still resident patients, the OR of a patient with a disability score of $12\left(=x_{2}\right)$, compared to a patient with a disability score of $7\left(=X_{1}\right)$, is $\exp [-0.32(12-7)]=0.20$. In other words, 
the odds of being discharged versus still resident for a patient with a disability score of 12 at admission is one fifth of the odds of a patient with a disability score of 7 at admission.

Table 5. Results of the trichotomous logistic regression analysis $(n=157)$

Term

Coeff. s.e.

Coeff./s.e. Exp(coeff.) $95 \%$ Conf. Int.'

Still resident versus deceased

Age (d)

Gender (d)

Financial means (d)

Prior living arrangements (d)

Househald composition (d)

Visits received

CSI score

Disability score

Number of diagnoses

Nature of main diagnosis (d)

$\begin{array}{rrrrrr}-0.95 & 0.43 & -2.23 & 0.39 & 0.17 & 0.90 \\ 1.04 & 0.45 & 2.33 & 2.83 & 1.17 & 6.83 \\ 0.09 & 0.52 & 0.18 & 1.09 & 0.40 & 3.03 \\ 0.70 & 0.42 & 1.69 & 2.01 & 0.89 & 4.59 \\ -0.09 & 0.42 & -0.21 & 0.92 & 0.40 & 2.08 \\ -0.00 & 0.01 & -0.72 & 1.00 & 0.98 & 1.01 \\ 0.03 & 0.06 & 0.46 & 1.03 & 0.92 & 1.16 \\ -0.17 & 0.07 & -2.52 & 0.84 & 0.74 & 0.96 \\ -0.18 & 0.30 & -0.61 & 0.84 & 0.47 & 1.50 \\ 0.97 & 0.44 & 2.18 & 2.64 & 1.11 & 6.25\end{array}$

Discharged versus deceased

Age (d)
Gender (d)

Financlal means (d)

Prior living arrangements (d)

Household composition (d)

Visits received

CSI score

Disability score

Number of diagnoses

Nature of main diagnosis (d)

Discharged versus still resident

Age (d)

Gender (d)

Financial mearis (d)

Pror living arrangements. (d)

Househoid composition (d)

Visits received

CSI score

Disability score

Number of diagnoses

Nature of main diagnosis (d)

$\begin{array}{rrr}-0.87 & 0.69 & -1.25 \\ 0.71 & 0.71 & 1.00 \\ 1.42 & 0.72 & 1.98 \\ 0.60 & 0.66 & 0.91 \\ 0.86 & 0.70 & 1.22 \\ -0.00 & 0.01 & -0.42 \\ -0.16 & 0.09 & -1.77 \\ -0.49 & 0.11 & -4.33 \\ -0.98 & 0.44 & -2.24 \\ -2.04 & 1.23 & -1.66\end{array}$

0.08

$-0.33$

0.67

1.32

0.70

$-0.10$

0.68

0.95

$-0.00$

$-0.19$

$-0.32$

.0 .80

$-3.01$

0.12
-0.47
1.93
-0.15
1.41
-0.01
-2.14
-3.03
-1.94
-2.53

0.64

0.67

0.01

0.09

0.11

0.42

1.19
0.42

2.03

4.14

1.82

2.36

1.00

0.85

0.61

0.37

0.13

1.08
0.72
3.74
0.91
2.59
1.00
0.83
0.73
0.45
0.05

1.08

0.29

0.18

0.98

0.26

0.69

0.98

0.69

0.59

0.20

0.01
1.62

8.18

17.00

6.64

9.32

1.02

1.02

0.77

0.89

1.45

1 Coeff. $=$ coefficient; s. $_{.}=$standard error; $\exp ($ coeff. $)=$ Odds Alatio; $95 \%$ Conf. Int. $=95 \%$ Confidence Interval of the Odds Ratio; (d) = dichotomous

The first comparison, involving still resident and deceased patients, shows that the odds of being still resident versus deceased after one year, is lower for patients aged over $80_{n}$, for males, for patients with higher disability scores $\left(O R_{12,8}=0.43\right)$, and for somatic patients. The comparison of the discharged patients with the deceased patients indicates that the odds of being discharged to being deceased within one year is lower for patients with higher disability scores $\left(O R_{12,}=0.09\right)$, and for patients with more diagnoses $\left(\mathrm{OR}_{3,1}=0.14\right)$. Financial means and the CSI score also seem to 
be of influence, but these associations did not reach statistical significance. Finally. comparing the discharged patients with the still resident patients, it is found that the odds of being discharged versus still resident is lower for patients with caregivers with higher CSI scores $\left(\mathrm{OR}_{10,4}=0.32\right)$, for patients with higher disability scores $\left(\mathrm{OR}_{12, y}=0.20\right)$, and for psychogeriatric patients. In this comparison, the number of diagnoses also seemed to be associated, but did not reach statistical significance.

The logistic regression model also provides predicted outcomes for individual patients according to their admission characteristics. The discrepancy between the observed and predicted outcomes can be viewed as a crude measure of the goodness of fit of the model. In table 6 these summed predictions are presented for each observed outcome. In all, $54 \%$ of the predicted outcomes corresponded with the observed outcomes. The model made most mistakes in differentiating between still resident and deceased patients; of the 64 deceased patients, 24 had been predicted by the model to be still resident and of the 70 still resident patients, 25 had been predicted to be deceased. Extreme mistakes - predicting discharged patients as deceased or vice versa - were made in only $7 \%$ of the cases.

Table 6. Observed and predicted outcomes of the nursing home stays

\section{Predicted outcome}

Observed outcome

Deceased

Still

rautcolne

Deceased

Still resident

Discharged

$\begin{array}{rr}34 & 24 \\ 25 & 39 \\ 5 & 7\end{array}$

39

7

Discharged

Total

Percentage

correct

Total

64

70

23

157

$\begin{array}{ll}64 & 53 \% \\ 70 & 56 \%\end{array}$

$23 \quad 48 \%$

\section{Discussion}

Although the number of patients in the study is not very high, as a consequence of which the number and categories of the independent variables had to be restricted, the independent association of several admission characteristics with the outcome of nursing home stays became clear.

The influence of the degree of disability, which is significantly associated with all outcomes, is obvious and consistent with previous research (see table 1). The number of diagnoses, as an indicator of medical complexity, only differentiated between being discharged and deceased. Because it is likely that in reality, medical complexity differentiates between being still resident and deceased as well, this suggests that either the groups were too small or that the number of diagnoses is too crude a measure of medical complexity. Age and gender only differentiated between being still resident and being deceased. Their influence, which resulted in males and patients over 80 being more likely to die, is more or less in line with the findings of other studies (see table 1). The nature of the main diagnosis did not differentiate between being discharged and being deceased. The association that somatic patients were more likely either to die or to be discharged, whereas psychogeriatric patients were 
more likely to stay, is not surprising since most of the mental disorders were dementhias, which are known to have a lengthy natural course. The CSI score differentiated between being discharged and still resident, indicating that patients whose caregivers experienced less strain prior to the admission were more likely to be discharged. A low CSI score can be explained in two ways. It might be due to the fact that the informal caregivers were capable of caring for the applicants and therefore did not experience strain. But it might also be due to the absence of an informal caregiver, because the admission followed an acute illness like a cardiovascular accident or hip fracture. Both explanations might be valid, irrespective of outcome category. The association found might be explained as follows. Informal caregivers who were strained by taking care of an applicant prior to the admission know what to expect of a discharge. Especially in those cases were strain was one of the main reasons for the admission, it is likely that they will be reluctant to consider discharge. For the patients whose caregivers were less or not strained, for whatever reason, previous experiences will have little or no impact on the decision to discharge the patient, thereby increasing the likelihood of discharge.

For $54 \%$ of the patients, the outcome of the nursing home stay was correctly predicted by the logistic regression model. Although a correct prediction rate of $100 \%$ is not possible on the basis of admission characteristics, since unforeseen events like a rellapsed CVA or the development of a new disease do occur during the stay and can greatly change the patient's condition (Kane et al. 1983), this figure is rather low. Extreme mistakes, which can (partly) be explained by these unfore-seen events, were not prevalent, but it appeared hard to distinguish between deceased and still resident patients. This might be due to the failure to include important admission characteristics into the model or to using insufficiently sensitive measures. Regarding the latter, it has already been mentioned that the number of diagnoses as a measure of medical complexity is possibly too crude. The same might be true for the measure of functio. nal status, as the totall score had to be used instead of the five component scores. More precise measurement of functional status and medicall condition, as well as including more of these kind of variables, might reveal more subtle differences in the health status of patients with different outcomes, and thus improve the prediction. With regard to the non-health variables, the measures of prior living arrangements and household composition may have been too insensitive, as dichotomizing always leads to the loss of part of the avallable information. Furthermore, including other nonhealth variables might improve the prediction as well. Our study indicated the independent association of the CSI score with the outcome of the nursing home stay. Therefore, a further exploration of characteristics of the social network and of prior living arrangements, in relation to their association with the outcome, might prove successful in this regard.

For the purpose of changing the use of nursing home care, non-health variables are as important as health variables. If the change in use is to be achieved by not admitting patients who are very likely to become long-stayers, then every variable that adds to the differentiation between long-stayers and short-stayers at admission is important. Things become different if the change is to be brought about by reducing the use through manipulation of the factors responsible for the outcome of nursing home care. For this purpose, factors have to be both causal in nature and changeable. In this respect, non-health variables are more promising than health variables: characteristics of the social network and prior living arrangements seem easier to manipulate than the health status of nursing home patients, and the causal nature is plausible. So, a further exploration of the extent to which these characteristics are related to the 
outcome of nursing home care is needed if the aim is to find ways of reducing the utilization of nursing homes.

Thus, next to functional status, number of diagnoses, and nature of the main diagnosis at admission, age, gender, and the strain experienced by informal caregivers prior to the admission were found to be indepently associated with the outcome of nursing home care. Further research should be directed especially towards the social network and prior living arrangements, as these factors are most promising if we are to find ways of reducing the utilization of nursing homes. 


\section{References}

Allison-Cooke S. Deinstitutionalizing nursing home patients: potentials versus impediments. The Gerontologist 1982; 22: $404-408$.

Branch LG, Jette AM. A prospective study of long term care institutionalization among the aged. American Journal of Public Health 1982; 72: 1373-1379.

Brody SJ, Poulshock SW, Masciocchi CF. The family caring unit: a major consideration in the long term support system. The Gerontologist 1978; $18: 556-561$.

Colerick EJ, George LK. Predictors of institutionalization among caregivers of patients with Alzheimer's disease. Journal of the American Geriatrics Society 1986; 34: 493498.

Diesfeldt HFG. Een studie rond de levensverwachting van patiëten in twee psychogeriatrische verpleeghuizen. Tijdschritt voor Sociale Geneeskunde 1979; 57: 343-350.

Dixon WJ, Brow MB, Engelman L, Jennrich RI. BMDP statistical software manual. Volume II. Berkeley/Las Angeles/Oxford, University of California Press 1990.

Evasthwick $C_{n}$ Rowe $G_{3}$ Diehr $P$, Branch $L$. Factors explaining the use of health care services by the elderly. Health Services Research 1984; 19: 357-382.

Frijters D, Aibbe MW, Mens JTh van. Verblijfsduur in verpleeghuizen. Een ordening in kort en lang verblijf. Tijdschrift voor Gerontologie en Geriatrie 1987;18: 15-20.

Garrard J, Kane RL, Radosevich DM, Skay CL, Arnold S, Kepferle L, McDermatt S, Buchanan JL. Impact of geriatric nurse practitioners on nursing-home residents" functional status, satisfaction, and discharge outcomes. Medicall Care 1990; 28: 271 . 283.

Heuvel WJA van den. Overleven vs overlijden in het verpleegtehuis. Tijdschrift voor Sociale Geneeskunde 1977; 55: 754-760.

Howe AL, Philips C, Preston GAN. Analysing access to nursing home care. Social Science and Medicine 1986, 23: $1267-1277$.

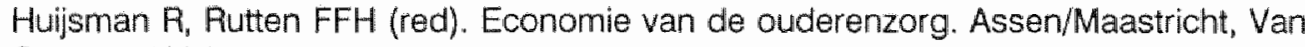
Gorcum 1989.

Jacobs $\mathrm{M}$, Trommel T, Gips $\mathrm{CH}$. Beoordelingsschaal Oudere Patiënten en verzorgingsbehoeftigheid, leeftijdsklassen en eenjaarsoverleving van psycho-geriatrische patiënten. Nederlands Tijdschrift voop Gerontologie 1978; 9: 27-34.

Kane AL. Bell $R$, Aiegler S, Wilson A, Keeler E. Predicting the outcomes of nursing home patients. The Gerontologist 1983; 23: 200-206.

Kane RL, Kane RA. Transitions in long term care. In: Ory MG, Bond K (eds). Aging and health care. Sociall science and policy perspectives. London/New York. Routledge 1989. 
Keeler EB, Kane RL, Solomon DH. Short- and long-term residents of nursing homes. Medical Care 1981; 19: 363-369.

Lewis MA, Kane RL, Cretin S, Clark V. The immediate and subsequent outcomes of nursing home care. American Journal of Public Health 1985; 75: 758-762.

Lewis MA, Leake B, Clark V, Leal-Sotelo M. Case mix and outcomes of nursing home patients. The importance of prior nursing home care and admission from home versus hospital. Medical Care 1989; 27: 376-385.

Lewis MA, Leake B, Clark V, Leal-Sotelo M. Changes in case mix and outcomes of readmissions to nursing homes between 1980 and 1984. Health Services Research 1990; $24: 713-728$.

Lichtenstein MJ, Federspiel CF, Schaffner W. Factors associated with early demise in nursing home residents: a case control study. Journal of the American Geriatrics Society 1985; 33: 315-319.

Liu K, Manton KG. The characteristics and utilization pattern of an admission cohort of nursing home patients. The Gerontologist 1983; 23: 92-98.

Liu K, Manton KG. The characteristics and utilization pattern of an admission cohort of nursing home patients (II). The Gerontologist 1984; 24: 70-76.

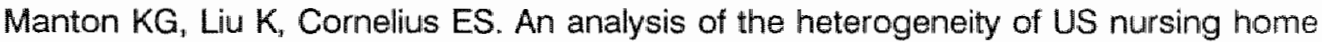
patients. Journal of Gerontology 1985; 40: 34-46.

Merkus JWFM. Verpleegtehuispatiënten. Een onderzoek naar de maatschappelijke omstandigheden, de behoefte aan verpleging en behandeling en naar het ziekteverloop van het patiëntenbestand en van nieuw opgenomen patiënten in een verpleegtehuis. Proefschrift Katholieke Universiteit Nijmegen. Nijmegen, 1974.

Ministerie van WVC. Financieel Overzicht Zorg 1990. Den Haag, Staatsuitgeverij 1989.

Remmen JWM. Bejaardenoordbewoners of verpleeghuispatiënten? Hoogezand, Uitgeverij Stubeg 1985.

Retsinas J, Garrity P. Going home: analysis of nursing home discharges. The Gerontologist 1986; 26 : $431-436$.

Ribbe MW, Mens JTh van. Enkele kenmerken van verpleeghuispatiënten. Nederlands Tijdschrift voor Geneeskunde 1986; 130: 642-646.

Robinson BS. Validation of a caregiver strain index. Journal of Gerontology 1983; 38 : 344-348.

Shapiro E, Webster LM. Nursing home utilization patterns for all Manitoba admissions, 1974-1981. The Gerontologist 1984; 24: 610-615.

SIG. Gebruikershandboek SIVIS. Utrecht, SIG 1984. 
SIG. Jaarboek Verpleeghuizen 1988. Utrecht, SIG 1989.

Smyer MA. The differential usage of services by impaired elderly. Journal of Gerontollogy 1980; $35: 249-255$.

Spence DA, Wiener $\mathrm{JM}$. Nursing home length of stay patterns: results from the 1985 national nursing home survey. The Gerontologist 1990; 30: 16-20.

Tobin SS, Kulys R. The family in the institutionalization of the elderly. Journal of Social Issues 1981; 37: 145-157.

Weissert WG, Scanlon WJ. Determinants of nursing home discharge status. Medical Care 1985; 23: 333-343.

Wierik MJM te, Frederiks CMA, Visser APh, Sturmans F. Verpleeghuisopname; een onderzoek bij op te nemen ouderen. Accepted by Tijdschrift voor Gerontologie en Geriatrie. 
HOOFDSTUK 9

BESLUIT 


\section{Inleiding}

In dit hoofdstuk worden de vraagstellingen, de onderzoeksmethoden en de resultaten van het onderzoek in hun geheel nog eens beschouwd en met elkaar in verband gebracht. Eerst wordt aandacht besteed aan de vraagstellingen en methoden van onderzoek, daarna wordt per vraagstetting ingegaan op de resultaten. Vervolgens worden enkele beleidsimplicaties besproken. Het hoofdstuk wordt afgesloten met een aantal aanbewelingen voor de zorg aan ouderen en verder onderzoek op dit terrein.

\section{Vraagstellingen en onderzoeksmethoden}

Het onderzoek heeft wee centrale vraagstellingen. De eerste vraagstelling is welke factoren bij ouderen, naast de mate van invaliditeit, tot opname in een verpleeghuis leiden; de tweede vraagstelling is welke factoren het verloop van de verpleeghuisopnamen bepalen. De onderzoeksopzet is voor beide vraagstellingen apart beschreven.

Voor de eerste vraagstelling zijn kenmerken van 157 ouderen met een verpleeghuisin. dicatie vergeleken met die van 135 ouderen met een positieve indicatie voor een plaats in het verzorgingshuis. Het onderzoek is uitgevoerd in Maastricht. De glegevens zijn verzameld door middel van mondellinge interviews met de oudere zelf en/of een informele zorgverlener. Naast de hulpbehoefte werd daarbij ingegaan op het sociale netwerk inclusief de belasting van de informele zorgverleners, de geestelijke toestand, de woonsituatie, de sociaal-economische status en het gebruik van professionele thuiszorg.

Voor de tweede vraagstelling - welke factoren bepalen het verloop van de verpleeghuisopname - zijn de ouderen die werden opgenomen in een verpleeghuis maximaal 1 jaar gevolgd. De gegevens woor dit longitudinale deel werden op twee manieren schriftelijk verzameld. De behandelend verpleeghuisarts vulde kort na opname en bij ontslag of overlijden c.q. na 1 jaar opname een vragenlijst in. De vragen hadden betrekking op de diagnosen, de functionele status, (het bereiken van) de behandeldoelen en de prognose. Daarnaast werd 2 weken na de opname, en vervolgens om de drie maanden, door het verplegend personeel van de afdeling waar de patiënt verbleef een Beoordelingsschaal voor Oudere Patiênten (BOP) gescoord (Van der Kam et al. 1971).

Bili de totstandkoming van deze uiteindelijke onderzoeksopzet hebben verschillende overwegingen een rol gespeeld. Deze zijn beschreven in de inlleiding en de daaropvolgende hoofdstukken. Een aantal gemaakte keuzes bij de onderzoeksopzet wordt hieronder van commentaar voorzien. Daarna wordt per vraagstelling ingegaan op de rosultaten van het onderzoek.

De omstandigheden die leiden tot opname in een verpleeghuis kunnen bij ouderen met een aanvraag voor verpleeghuisopname direct geinventariseerd worden. Ouderen met een verpleeghuisindicatie vormden dan ook het uitgangspunt. Omdat het onderzoek gericht was op factoren die, naast de mate van invaliditeit, van invloed zijn op opname in een verpleeghuis, dienden zij vergeleken te worden met een groep ouderen zonder verpleeghuisindicatie maar met een zelfde mate van invaliditeit. Besloten werd om ouderen met een positieve indicatie voor opname in een verzorgingshuis als vergelijkingsgroep te nemen. De term vergelijkingsgroep is consequent gehanteerd omdat het van het begin af duidelijk was dat een echte controlegroep (een groep ouderen met een gelijk niveau van hulpbehoefte) niet tot de onderzoeksmogelijkheden behoorde. De resultaten van dit onderzoek en die van Frederiks (1990) rechtvaardigen de keuze voor verzorgingshuisaanvragers als vergelijkingsgroep: zij lijken 
het meeste op de ouderen met een verpleeghuisindicatie. Uit het onderzoek van Frederiks (1990) blikt dat thuiswonende ouderen met en zonder professionele thuiszorg beduidend minder huishoudelijke en ADL-beperkingen hebben dan de ouderen met een verpleeghuisindicatie. De verzorgingshuisbewoners hebben eem hulpbehoefte die vrijwel overeenkomt met die van de ouderen met een positieve indicatie voor een verzorgingshuis en zouden om die reden ook als vergelijkingsgroep hebben kunnen fungeren. Echter, bij verzorgingshuisbewoners speelt een aantal kenmerken geen rol meer (bijvoorbeeld het gebruik van professionele thuiszorg en de woonsituatie). Ook kunnen sommige kenmerken weranderd zijn na de opname in het verzorgingshuis (bijvoorbeeld het sociale netwerk). Omdat deze problemen zich niet voordoen bij ouderen met een positieve indicatie voor het verzorgingshuis en hun hulpbehoefte vrijwell overeenkomt, vormen zij de best mogelijke vergelijkingsgroep.

De ouderen met een verpleeghuisindicatie en met een positieve indicatie voor opname in een verzorgingshuis en hun informele zorgverleners werden zoveel mogelik voór de daadwerkelijke opname geinterviewd. Dit tijdstip van interviewen is duidelijk ten koste gegaan van de respons: de maatschappelijk werkenden van zowel de beide verpleeghuizen als de indicatiecommissie meldden lang niet alle ouderen aan voor het onderzoek. Gegeven de situatie - door de aanvraag bevonden de ouderen zich immers in een afhankelijke positie - vonden de maatschappelijk werkenden het vaak moeilijk en conflicterend met het doel van het huisbezoek om medewerking aan het onderzoek te vragen. Het voordeel dat door het betrekken van aanvragers van opname in het onderzoek de omstandigheden die leiden tot de aanvraag direct geinventariseerd konden worden, wordt dus beperkt door het optreden van nonrespons. De onderzoeksresultaten hebben hierdoor aan waarde ingeboet. Uit de redenen voor het niet aanmelden en het alsnog weigeren van een interview is af te leiden dat bij de groep verpleeghuisaarwragers ouderen met een complexe situatie voorafgaand aan de opname ondervertegenwoordigd zijn. Bij de groep verzorgingshuisaanvragers zijn dat vooral ouderen met geestelijke problematiek. Niettemin bleken de deelnemende verpleeghuisaanvragers bij opname in het verpleeghuis mimstens zo hulpbehoevend te zijn als verpleeghuispatiënten in het algemeen. De deelnemende verzorgingshuisaanvragers bleken bijna evenveel huishoudelijke en ADL-beperkingen te hebben als een aselecte steekproef van Maastrichtse verzorgingshuisbewoners. Hoewel deze vergelj kbaarheid in hulpbehoefte geruststellend is voor de generaliseerbaarheid van de bevindingen ten aanzien van zowel de eerste als tweede vraagstelling, is het geen waarborg hiervoor. Replicatieonderzoek is daarom gewenst. Hoewel de verzorgingshuisaanvragers de meest geschikte vergellikingsgroep voor de verpleeghuisaanvragers vormen, werd de vergelijking van beide groepen bemoeilikt doordat de hulpbehoefte van de verzorgingshuisaanvragers minder groot was dan die van de verpeeghuisaanviagers. Daarnaast vormen de ouderen met een verpleeghuisindicatie een meer heterogene groep dan de ouderen met een positieve indicatie voor het verzorgingshuis. De laatsten deden allem vanuit de thuissituatie een aanvraag voor opname, die in principe definitief is. De ouderen met een verpleeghuisindicatie daarentegen waren zowel afkomstig uit de thuissituatie (inclusief het verzorgingshuis) als het ziekenhuis. Bij deze groep is de opname niet altijd definitief. De meest eenduidige vergelijking zou zijn om de ouderen met een verzorgingshuisaanvraag te vergelijken met nog zelfstandig wonende ouderen waarbij de verpleeghuisopname definitief zal zijn. Echter, bij de opname in het verpleeghuis is vaak niet duidelijk of ouderen definitief dan wel tijdelijk opgenomen worden (hoofdstuk 2, 7 en 8). Mede hierom is de tweede vraagstelling in het onderzoek opgenomen. Wel zijn, omwille van de vergelikbaarheid, de ouderen die vanuit het verzorgingshuis een aanvraag deden voor 
opname in een verpleeghuis bij de uiteindelijke vergelijking buiten beschouwing gelaten. Met behulp van discriminant-analyses zijn aldus de kenmerken vergeleken van:

- zelfstandig wonende ouderen met een aanvraag voor het verpleeghuis;

- ouderen die vanuit het ziekenhuis een aanvraag deden voor het verpleeghuis en die voordien zelfstandig woonden en

- ouderen met een positieve indicatie voor opname in een verzorgingshuis.

Hoewel op deze manier de groepen redelijk valide met elkaar vergeleken konden worden, verdient het voor toekomstig onderzoek aanbeveling om stringentere in-en uitsluitingscriteria te hanteren, waardoor de heterogeniteit van de groep ouderen met een verpleeghuisindicatie wordt verkleind. Afhankelijk van de vraagstelling kunnen die criteria betrekking hebben op kenmerken zoals de verblifsituatie waarin de aanvraag gedaan wordt, de reden van de opname of de aard van de aandoeningen (somatisch/psychogeriatrisch of chronisch/acuut). Door zo de variabiliteit binnen de onderzoekspopulatie te beperken, kunnen de resultaten eenduidiger geinterpreteerd worden.

Voor de tweede vraagstelling van het onderzoek - welke factoren bepalen het verloop van de verpleeghuisopname - zijn de ouderen die werden opgenomen in een verpleeghuis maximaal 1 jaar gevolgd. De veronderstelling daarbij was dat de reactiveerbare patiënten binnen 1 jaar uit het verpleeghuis zouden zijn ontslagen en dat zij die na 1 jaar nog opgenomen zijn "llong-stay" patiënten zouden worden. Deze veronderstelling komt vrij goed overeen met de realiteit: na 1 jaar opname werd bij slechts 4 patiënten verwacht dat ontslag alsnog plaats zou vinden (hoofdstuk 7). Van de 157 ouderen die werden opgenomen in een verpleeghuis, waren na 1 jaar opname 64 ouderen overleden, 70 ouderen waren nog steeds opgenomen en slechts 23 ouderen waren naar huis of naar een verzorgingshuis ontslagen. Deze onevenwichtige verdeling over de 'uitkomsten' van de opname heeft vooral de logistische regressie-analyse bemoeilijkt. In deze analyse werden opname-kenmerken van de ouderen gerelateerd aan de "uitkomst" van de opname (hoofdstuk 8). Het aantal onderzoekspersonen in de kleinste groep (hier dus de 23 ouderen die waren ontslagen) is namelijk bepalend voor het aantal variabelen en de categorieën daarvan dat in de analyse opgenomen kan worden (Tabachnik en Fidell 1989). Om deze redenen is een aantal variabelen gedichotomiseerd of helemaal niet opgenomen in de analyse en is een samenvattende maat voor de functionele status gebruikt in plaats van de vijf afzonderlijke maten daarvan. Ook het onderzoeken van mogelijke interactie tussen variabelen was hierdoor niet mogelijk. Gelukkig was de 'fit' van het logistische regressie-model zonder interactietermen redelijk. Dit impliceert dat de data zonder interactietermen op bevredigende wijze beschreven konden worden.

\section{Factoren van Invloed op opname in verpleeghuizen}

Om na te gaan welke factoren, naast de mate van invaliditeit, leiden tot verpleeghuisopname zijn de thuiswonende ouderen met een verpleeghuisindicatie, die al dan niet vanuit het ziekenhuis werden opgenomen, vergeleken met de ouderen met een positieve indicatie voor het verzorgingshuis. Bij de discriminant-analyses werden de volgende kenmerken, geordend naar het model van Andersen (1975), betrokken: demografische variabelen, het sociale netwerk, de woonsituatie (als predisponerende factoren), de sociaal-economische status, het gebruik van professionele thuiszorg (als faciliterende factoren) en het aantal huishoudelijke en ADL-beperkingen als behoeftefactor (hoofdstuk 5). De geestelijke toestand van de ouderen kon bij deze analyse helaas niet betrokken worden. Omdat veel van de ouderen met een verpleeghuisindi- 
catie niet zelf geïnterviewd konden worden, is bij een te klein aantal informatie hierover aanwezig.

De resultaten van de discriminant-analyses laten zien dat de groepen aarwragers goed onderscheiden konden worden: $91 \%$ wan de ouderen werd in de goede groep ingedieeld. Dit is $50 \%$ meer dan wat op basis van het toeval verwacht kan worden. De behoeftefactor bleek, zoals verwacht kon worden, de meeste inbreng te hebben. Van de predisponerende factoren waren de informele zorg-score, de samenstelling van het huishouden en het ontvangen bezoek belangrijke discriminerende variabelen; het gebruik van professionele thuiszorg was de enige belangrijke faciliterende factor. Tot zover komen de resultaten overeen met het model van Andersen (1975): naast de behoeftefactor is er een samenhang met predisponerende en faciliterende factoren. Wanneer we echter nagaan op welke manier de onderscheiden groepen van elkaar verschillen op de discrimimerende variabelen, dan blijkt het anders te liggen. Naast de grotere hulpbehoefte van de ouderen met een verpleeghuisindicatie, bleken zij vaker samen te wonen en meer bezoek te ontvangen dan de ouderen met een positieve indicatie voor een verzorgingshuis. De ouderen die vanuit de thuissituatie in het verpleeghuis werden opgenomen bleken bovendien veel meer informele en professionele thuiszorg te gebruiken dan de positief geindiceerden voor het verzorgingsinuis. Kortom: de richting van een aantal samenthangen is tegengesteld aan de richting die het model van Andersen (1975) veronderstelt. Het model suggereert immers dat, gegeven de hulpbehoefte, het zorggebruik afhangt van predisponerende en faciliterende factoren, waarbij meer zorg wordt gebruikt naarmate de predisponerende factoren en de faciliterende factoren 'slechter' dan wel "beter" zijn. Deze bevinding is des te meer opvallend amdat in de complementaire studie, waarin op dezelfde wijze ouderen met en zonder professionele thuiszorg en verzorgingshuisbewoners vergeleken zijn, de samemhangen van de informele zorg-score, het al dan niet alleen wonen en het ontwangen bezoek met het zorggebruik wél de goede richting hadden. De ouderen zonder professionele thuiszorg hadden de meeste informele zorg en woonden het meest samen met anderen. Het ontvangen bezoek was het laagst bij verzorgingshuisbewoners, maar differentieerde niet tussen ouderen met en zonder professionele thuiszorg. Overigens was ook in deze studie de hulpbehoefte de meest discriminerende factor: zoals verwacht waren de verzorgingshuisbewoners het meest en de niet-gebruikers het minst hulpbehosvend (Frederiks 1990).

De veronderstelling, dat het zorggebruik van ouderen op het continuüm van zelfzorg en informele zorg aan de ene kant en gespecialiseerde institutionele zorg aan de andere kant, gegeven de hulpbehoefte, bepaald wordt door hun predisponerende en faciliterende factoren, lijkt dus wel op te gaan voor het glebruik van professionele thuiszorg en het verzorgingshuis maar niet meer voor het verpleeghuis. Blijkbaar wordt bij de ouderen met een verpleeghuisindicatie dit mechanisme 'overruled' door hun hulpbehoefte ten gevolge van hun gezondheidstoestand. Van de ouderen die vanuit de thuissituatie (inclusief het verzorgingshuis) in het verpleeghuis werden opgenomen had bijna de helft een psychische stoornis (veelal dementie) als hoofd. diagnose " bij $14 \%$ waren dat aandoeningen van het hartvaatstelsel en $12 \%$ had kanker (hoofdstuk 3). Tezamen met het gegeven dat zij over een goed sociaal netwerk beschikten en vrijwel allemaal gebruik maakten van professionele thuiszorg, duidt dit erop dat de hulpbehoefte ten gevolge van deze chronische aandoeningen in de loop der tijd zo groot en complex geworden is, dat het verpleeghuis de enige oplossing is.

Een extra argument hiervoor wordt gevormd door de bevindingen van de afzonderliike analyse over de belasting van de informele zorgverleners van de positief geindiceerde ouderen en de thuiswonende verpleeghuisaanvragers (hoofdstuk 6). Bij de 
zorg voor de ouderen met een verpleeghuisindicatie bleek veel vaker een informele zorgverlener betrokken te zijn dan bij de zorg voor de ouderen met een positieve indicatie woor het verzorgingshuis. Bovendien ervaarden de informele zorgverleners van de thuiswonende ouderen met een verpleeghuisindicatie beduidend meer belasting bil het zorgen woor deze hulpbehoevende ouderen dan de informele zorgverleners van de ouderen met een positieve indicatie voor het verzorgingshuis. De ervaren belasting bleek samen te hangen met onder meer de zorg die door de informele zorgverlener verleend werd, de hulpbehoefte van de oudere en het al dan niet samenwonen met de oudere. Ook wanneer gecontroleerd werd voor de invloed van deze en andere tactoren, bleef een verschil in ervaren belasting bestaan.

Bij de ouderen die vanuit het ziekenhuis in een verpleeghuis werden opgenomen zijn de omstandigheden wat anders. Het 'andere' komt niet zozeer voort uit hun sociale netwerk of het gebruik van zorg, maar uit de aard van hun aandoeningen. Ook hun sociale netwerk is goed te noemen, getuige het ontwangen en afgelegde bezoek voorafgaand aan de ziekenhuisopname en de samenstelling van het huishouden. Dat zij het minst informele zorg ontvangen is inherent aan het ziekenhuisverblijf. Hun beperkte gebruik van professionele thuiszorg voorafgaand aan de ziekenhuisopname hangt samen met het feit dat bij hen meer acute aandoeningen of een duidelijke verslechtering van een chronische aandoening de corzaak van de opname is: $41 \%$ had een aandoening van het hartvaatstelsel (inclusief de cerebrovasculaire aandoeningen), $23 \%$ een psychische stoornis en $11 \%$ een ongevalsletsel. De hulpbehoefte die daarvan het gevolg is, is dan te groot om in de thuissituatie verzorgd te kunnen worden. ondanks het goede socialle netwerk en/of (uitbreiding varn) de professionele thuiszorg. Samenvattend zijin dus de behoeftefactoren - de hulpbehoefte en aard van de aandoeningen - doorslaggevend bij opname in een verpleeghuis. Incongruent aan het model van Andersen spelen predisponerende en faciliterende factoren, i.c. het sociale netwerk en het gebruik van professionele thuiszorg, bij een bepaalde mate van hulpbehoefte geen rol meer. Gegeven die hulpbehoefte zijn deze factoren bij chronische aandoeningen uiteindelijk niet meer voldoende en bij meer acute aandoeningen niet voldoende om verpleeghuisopname te voorkomen.

\section{Factoren van invloed op het verloop van verpleeghuisopnamen}

Om na te gaan welke factoren het verloop van de opname bepalen zijn de ouderen die werden opgenomen in een verpleeghuis maximaal 1 jaar gevolgd. Deze longitudinale gegevens zijn op verschiliende manieren geanalyseerd. Eerst is met behulp van de Beoordelingsschaal Oudere Patienten (BOP. Van der Kam et al. 1971) het feitelijk verloop van de verpleeghuisopnamen nagegaan, waarbij onderscheid is gemaakt naar het doel van de opname (hoofdstuk 7). Vervolgens is de relatie van een aantal opnamekenmerken van de patiënten met de "uitkomst' van de opname - het al dan niet overleden, ontslagen of nog opgenomen zijn - nagegaan met behulp van logistische regressie-analyse (hoofdstuk 8).

Van de 157 ouderen die werden opgenomen in het verpleeghuis was het doel van de behandeling bil $54 \%$ permanente ondersteuning van een aantal levensfuncties (hierna aangeduid als chronische patiënten), bij $35 \%$ reactivering en $11 \%$ was voor een ander doel opgenomen. De laatsten vormen een kleine en heterogene groep die daarom buiten beschouwing is gelaten. Na éen jaar was bijna een derde van de reactiveringspatiënten naar huis of naar een verzorgingshuis ontslagen, $40 \%$ was nog opgenomen en $29 \%$ was overleden. Bij de chronische patiënten was na én jaar bijna de helft overleden; $2 \%$ was ontslagen en de andere heltt was nog opgenomen. 
Uit de analyse wan de BOP-gegevens kwam, niet onverwacht, naar voren dat de verpleeghuisopname bij chronische en reactiveringspatienten verschillend verloopt. De chronische patiënten bleken vanaf de opname op alle subschalen van de BOP gemiddeld meer problemen te hebben dan de reactiveringspatiënten, met uitzondering van de subschalen lichamelijke invaliditeit en depressief gedrag. Tijdens de opname namen bovendien de problemen bij chronische patienten op andere subschalen van de BOP toe dan bij de reactiveringspatiënten. Alleen de hulpbehoevendheid nam bij beide groepen toe. Bij de chronische patiënten namen naast de hulpbehoevendheid, de lichamelijke en psychische invaliditeit en de inactiviteit toe tijdens de opname. Dit komt voort uit de aard van hun aandoeningen: bij meer dan de helft van deze groep was de hoofddiagnose een psychische stoomis. Bij de reactiveringspatienten namen naast de hulpbehoevendheid, de agressiviteit en het depressief gedrag toe; het laatste zelfs tot een hoger niveau dan bij de chronische patiënten. Een mogelijke verklaring hierwoor is dat bij hen het ziekte-en opnameproces snel is verlopen: een groot deel van hen werd opgenomen ten gevolge van acute aandoeningen zoals een CVA of ongevalsletsel. Het in korte tijd moeten verwerken van de eigen invaliditeit en de opname heeft dan zijn weerslag op de geestelijke toestand, zeker wanneer blijkt dat de reactivering niet het gewenste resultaat heeft en ontslag wit het verpleeghuis toch niet meer mogellik is, hetgeen bij tweederde van deze patiënten het geval bleek te zijn.

Om na te gaan waarom de reactivering bij tweederde van de patienten niet het gewenste resultaat had, zijn gegevens van deze groep apart geanalyseerd. Naast de BOP-gegevens is daarbij gebruik gemaakt van deels kwalitatieve informatie die van de behandelende verpleeghuisartsen verkregen is. Deze sibjgroepanalyse toonde aan dat de ontslagen reactiveringspatiënten bij opname op een aantal kenmerken duilidelijk verschilden van de overleden en de na éen jaar nog opgenomen reactiveringspatiënten. De ontslagen patiënten hadden op alle subschalen van de BOP de minste problemen, met uitzondering van agressiviteit. Ook op een invaliditeitsschaal scoorden zij gemiddeld het laagst. Daarnaast hadden zij vaker minder diagnosen. De binnen éen jaar overleden patiënten waren wat deze kenmerken betreft het slechtst af bij opname. De nog opgenomen patiënten namen een tussenpositie in. Aanwijzingen dat bepaalde aandoeningen beter te reactiveren zijn dan andere aandoeningen, werden niet gevonden. Als redenen voor het niet (geheel) bereiken van de behandeldoelen voor ADL en mobiliteit werden, naast complicaties zoals een recidief CVA of operatie, onder meer het onderschatten van de handicaps en algehele achteruitgang genoemd. Overigens is niet helemaal duidelijk in hoeverre de verpleeghuisartsen het doel reactivering breed interpreteerden om maar geen patiënten van mogelijke functieverbetering uit te sluiten. De genoemde redenen voor het niet (geheel) bereiken van de behandeldoe. len wijzen wel in deze richting. Ook het gegeven dat zij bij een aantal patiénten bij opname al sceptisch waren over het resultaat van de reactivering duidt hierop: bij een aantal patiënten werd als meest waarschijnlijke situatie over 1 jaar of nog opgenomen of niet te voorspellen aangegeven (respectievelijk 9 en 5 patienten). Bij een klein aantal patienten bleek het niet beschikbaar zijn van andere zorgvormen een belem. mering voor ontslag te zijn.

Met behulp van logistische regressie-analyse is vervolgens voor de gehele groep van 157 ouderen nagegaan welke opname-kenmerken samenhangen met het al dan niet overleden, nog opgenomen of ontslagen zijn na één jaar opname. Naast de functionele status, het aantal diagnosen en de aard van de hoofddiagnose (somatisch of psycho-geriatrisch) bij opname, als maten voor de hulpbehoefte en gezondheidstoestand, werden enkele demografische variabelen, de toereikendheid van financiële middelen, de herkomst, en kenmerken van het sociale netwerk in de analyse opgeno- 
men. De functionele status bij opname bleek geassocieerd te zijn met alle "uitkomsten' van de opname; andere opnamekenmerken bleken een onafhankelijke relatie te hebben met én of twee mogelijke "uitkomsten". De kans om mog opgenomen te zijn na één laar versus te zijn overleden, is kleiner voor oudere patiënten, mannen, patiënten met een slechtere functionele status bij opname en voor somatische patienten. De kans om ontslagen te worden versus te zijn overleden, is kleiner voor patiënten die bij opname een slechtere functionele status hadden en voor patiënten die bij opname meer diagnosen hadden. Tenslotte, de kans om ontslagen te worden, in vergelijking met nog opgenomen zijn, is kleiner voor patiënten met een slechtere functionele status bil opname, voor psychogeriatrische patiënten en voor patiënten waarvan de informele zorgverleners meer belasting ervaarden voorafgaand aan de opname. De associatie met de ervaren belasting verdient enige toelichting omdat weinig of geen belasting van de informele zorgverleners op twee manieren verklaard kan worden. Het kan zijn dat de informele zorgverleners opgewassen waren tegen de problemen en stress die de zorg voor deze ouderen met zich meebrengt. Ook is het mogelijk dat er geen informele zorgverlener was, omdat de opname het gevolg is van een acute aandoening. Beide verklaringen zijn onafhankelijk van de 'uitkomst' van de opname. Het is evenwel plausibel dat zij, vanwege het feit dat zij weinig of geen belasting ervaarden, minder afwijzend en terughoudend tegenower ontslag stonden dan de informele zorgverleners die zich voorafgaand aan de opname wel redelijk tot zwaar belast voelden, hetgeen de associatie dan verklaart.

Op basis van het logistische regressie-model werd de 'uitkomst' van de opname bij slechts $54 \%$ van de patiënten goed voorspeld. Dit percentage is (te) laag, alhoewel het op basis van opnamekenmerken alléén nooit 100\% kan worden. Tijdens de opname doen zich immers bij een aantal patiënten onvoorziene omstandigheden voor, zoals een recidief CVA, die de toestand van de patiënt in hoge mate kunnen veranderen. Ook wordt het beeld vertroebelt, doordat ontslag bij een klein aantal patiënten niet heeft plaatsgevonden vanwege de beperkte beschikbaarheid van andere voorzieningen. Deze patiënten behoorden nu tot de groep nog opgenomen patiënten, terwijl zij bij beschikbaarheid van deze voorzieningen tot de ontslagen groep behoord zouden hebben. Extreme fouten, waarbij ontslagen patiënten als overleden patiënten voorspeld werden en vice versa, werden door het logistische regressie-model weinig gemaakt. Het bleek op basis van het model vooral moeilijk om te voorspellen welke patiënten na 1 jaar overleden dan wel nog opgenomen zouden zijn. Het is aannemelijk dat de predictie verbeterd kan worden door meer en andere kenmerken van het sociale netwerk en de eerdere woonomstandigheden in de analyse op te nemen en door gevoeliger maten voor de functionele status en de gezondheidstoestand te gebruiken.

Samenvattend zijn van de geanalyseerde opnamekenmerken de functionele status, het aantal diagnosen, aard van de hoofddiagnose, leeftijd, geslacht en de belasting die de informele zorgverleners voorafgaand aan de opname ervaarden gerelateerd aan de 'uitkomst' van de opname.

\section{Beleidsimplicaties}

De aanleiding van dit onderzoek is gelegen in het beoogde substitiebeleid ten aanzien van de zorg voor ouderen. Door het vervangen van professionele zorg door zelfzorg en informele zorg, van intramurale zorg door semi- en extramurale zorg en varn curatieve zorg door preventieve zorg moet bereikt worden dat ouderen zolang mogelijk zelfstandig kunnen blijen functioneren en dat de ouderenzorg betaalbaar blift (zie ook hoofdstuk 2). Wat zijn de implicaties van de onderzoeksresultaten voor dit beleid? 
De vergelijking van de kenmerken van ouderen met een verpleeghuisindicatie met die van ouderen met een positieve indicatie voor het verzorgingshuis laat zien dat beide groepen meer van elkaar verschillen dan met elkaar overeenkomen. De opvatting dat verpleeg- en verzorgingshuizen steeds moeiliker van elkaar te onderscheiden zijn (Remmen 1985, Ministerie van WV 1988 en 1989, Commissie Structuur en Financiering Gezondheidszorg 1987, Mootz et al. 1986), wordt dus niet bevestigd door onze onderzoeksresultaten. Uit de resultaten komt eveneens naar voren dat alternatieven voor opname gemakkelijker te bedenken en uit te voeren zijn voor de ouderen met een positieve indicatie voor het verzorgingshuis dan voor de ouderen met een verpleeghuisindicatie.

De kenmerken van de ouderen met een positieve indicatie voor opname in een verzorgingshuis suggereren dat voor ongeveer de helft van hen alternatieve vormen van zorg mogelijk zijn (zie hoofdstuk 4). Dit betreft dan de ouderen met weinig huishoudelijke beperkingen. Voor hen zou (aanvullende) thuiszorg, zeker bij aanwezigheid van informele zorg, voldoende moeten zijn om in de hulpbehoefte te voorzien. Voorwaarde daarbij is wel dat een oplossing gevonden wordt voor de geestelijke problematiek die bij een deel van hen aangetroffen werd. Zowel de wens om op korte termijn opgenomen te worden als de gezondheidsbeleving bleken namelijk sterker geassocieerd te zijn met de aanwezigheid van eenzaamheidsgevoelens en depressieve klachten dan met het aantal huishoudelijke beperkingen. Hoewel de ouderen zelf veelal lichamelijke achteruitgang als reden opgaven voor de aanvraag, blijkt hieruit dat geestelijke problematiek vaak een achterliggende reden voor de aanvraag was en magelijk een belangrijke reden voor de uiteindelijke opname is. Bij de aanpak ervan kunnen mogellik vrij nieuwe voorzieningen als dagopvang en huiskamerprojecten een rol spelen. Of deze voorzieningen inderdaad in staat zijn om de problematiek te verminderen dient nog onderzocht te worden (Nies 1989, Nuyens 1988). Ook het regellmatig bezoeken van de ouderen door beroepskrachten of vrijwilligers zou een aanpak kunnen zijn; de effecten van het preventief huisbezoek door wijkverpleegkundigen wordt momenteel onderzocht (Van Rossum en Frederiks 1988). Voor de ouderen met veel huishoudelijke beperkingen zijn alternatieve vormen van zorg moeilijker te realiseren. Bij hen was vaak ook sprake van ADL-beperkingen en bovendien werden bij hen vaker depressieve klachten en geheugenstoornissen aangetroffen. Zij maakten dan ook relatief veel gebruik van zowel professionele als informele zorg. Gezien de hulpbehoefte en het al aanwezige zorggebruik is het verzorgingshuis voor hen de aangewezen voorziening.

Zoals vermeld lijken de substitutiemogelijkheden voor ouderen met een verpleeghuisindicatie veel geringer te zijn. De op zich woor de hand liggende mogelijkheild om ook bij deze ouderen de minst hulpbehoevenden alternatieve zorg te bieden, wordt niet alleen gefrustreerd door hun veell grotere hulpbehoefte; ook de resultaten van de longitudinale analyse manen tot voorzichtigheid. De ouderen die bij opname het minst hulpbehoevend waren hadden immers de meeste kans om met een verbeterde validiteit ontslagen te worden. Hoewel gecontroleerd onderzoek nodig is om na te gaan in hoeverre de functieverbetering het gevolg is van de reactivering dan wel van spontaan herstel, ligt hierin vooralsnog voor deze ouderen de legitimatie van dle opname.

De doelgroep voor substitutie wordt dan gevormd door de ouderen die qua hulpbehoefte een tussenpositie innemen. Voor deze groep, die afhankelijk van de te hanteren afkappunten voor hulpbehoefte in omvang varieert, zullen alternatieven als (meer) professionele thuiszorg en (langer) verblijf in een verzorgingshuis in hun huidige vorm weinig effect sorteren. 
Immers, de ouderen die niet varuit een ziekenhuis in het verpleeghuis werden opgenomen woonden of in een verzorgingshuis of maakten, naast informele zorg, vaak al gebruik van professionele thuiszorg. Bij de ouderen die vanuit het ziekenhuis werden opgenomen was het professionele zorggebruik daaraan voorafgaand minder. Niettemin geldt ook voor hen dat (meer) professionele thuiszorg beperkt effect zal hebben. Ongeacht de herkomst hadden de meeste ouderen immers 3 of meer ADL-beperkingen. Omdat de ADL een hierarchische structuur heeft (Frederiks 1990), betekent dit in het algemeen dat men, naast het huishouden "tenminste hulp nodig heeft bij zichzelf wassen, aan- en uitkleden en in en uit bed gaan. Hierbij is twee keer per dag ADL. ondersteuning nodig. Bij meer beperkingen is ook hulp bij het gebruik van het toilet en bij het binnenshuis verplaatsen nodig, hetgeen impliceert dat ADL-ondersteuning op verschillende tijdstippen gedurende de dag nodig is. Ondanks de 24-uurs bereikbaarheid is professionele thuiszorg alleén niet voldoende om hierin te voorzien. Informele zorg is hierbij onontbeerlijk. Bil de ouderen die vanuit de eigen omgeving werden opgenomen, werd deze zorg al in hoge mate verleend. Gezien de ervaren belasting van de informele zorgverleners en het feit dat de hulpbehoefte toeneemt in de tijd, zall meer thuiszorg bij deze ouderen de opname hooguit enigszins kunnen uitstellen. Hetzelfde geldt voor de ouderen die voorafgaand aan de ziekenhuisopname geen of weinig gebruik maakten van professionele zorg. Doordat de hulpbehoefte in de tijd toeneemt, kan het beroep op de informele zorgverleners zo groot worden, dat ook bij hen alleen uitstel van opname - zij het mogelijk wat langer - bewerkstelligd kan worden.

Om dezelfde reden lijkt voor de ouderen met een verpleeghuisindicatie (langer) verblijf in een verzorgingshuis in zijn huidige vorm niet mogelijk. Zij hebben niet alleen veel meer huishoudelijke en ADL-beperkingen dan verzorgingshuisbewoners, maar ook meer psychische problemen, zoals gemeten met de Beoordelingsschaal Oudere Patiënten (hoofdstuk 4 en 7). Een aantal van deze problemen bleek bovendien in de tijd toe te nemen. De verzorgingshuizen worden momenteel al geconfronteerd met bewoners die hulpbehoevender zijn en meer psychosociale problemen hebben dan een aantal jaren geleden. Vooral het laatste betekent dat naast de lichamelijke zorg meer aandacht en begeleiding nodig is. Het huidige personeel in verzorgingshuizen is daar nauwelijks voor opgeleid (hoofdstuk 4, Van Loveren-Huyben et al. 1985, Frederiks 1990, VNB 1990). Zonder personele aanpassingen, in kwantitatieve en kwalitatieve zin, en bouwkundige aanpassingen (zie hoofdstuk 2) lijkt (langer) verblijf in een verzorgingshuis voor de verpleeghuispatiënten dan ook geen alternatief te zijn. Mogelijk wordt dit in de nabije toekomst anders. Vanwege het chronisch beddentekort in verpleeghuizen bestaat sinds kort de mogelijkheid dat ouderen met een verpleeghuisindicatie in het verzorgingshuis verzorgd kunnen worden. Het verzorgingshuis wordt daarbij extra ondersteuning vanuit een verpleeghuis geboden. Door deze extra zorg zou de 'laatste gang' naar het verpleeghuis voor deze ouderen wellicht niet meer nodig zijn. Momenteel worden experimenten met deze "verpleeghuiszorg buiten de muren' door middel van subsidies gefaciliteerd (Ministerie van WVC 1989). Of deze vorm van substitutie inderdaad mogelijk is zullen de resultaten ervan uitwijzen. Hierbij dient gerealiseerd te worden dat een verschuiving van hett verpleeghuis naar het verzorgingshuis op grote schaal niet alleen de kosten van beide voorzieningen zal verhogen, maar ook het leetklimaat van vooral verzorgingshuizen negatief zal beinvloeden.

Een ander aanknopingspunt voor substitutie wordt gevormd door de bevindingen omtrent de belasting die de informele zorgverleners ervaarden. Hoewel de hulpbehoefte de doorslaggevende factor bij opname in een verpleeghuis bleek te zijn, kwam uit de afzonderlijke analyse naar voren dat de informele zorgverleners van de thuiswo- 
nende ouderen met een verpleeghuisindicatie zich zwaarder belast voelden dan dege. nen die betrokken waren bij de zorg voor een oudere met een aanviaag woor het verzorgingshuis. Bovendien bleek dat ouderen waanan de informele zorgverleners minder belasting ervaarden, onafhankelijk van de hulpbehoefte, meer kans hadden om uit het verpleeghuis ontslagen te worden. Indien deze relaties causaal zijn "hetgeen aannemelijk is, kan dit betekenen dat uitstel van opname of eerder ontslag bewerkstelligd kan worden door de belasting van informele zorgverleners te verminderen. Hiervoor zijn verschillende strategië̈n mogelijk. Enerzijds kan men proberen de informele zorgverleners emotioneel te ondersteunen door bijvoorbeeld gespreksgroepen, anderzijds kan men daadwerkelike steun verlenen door regelmatig wijdelijk de zorg over te nemen. Voorbeelden hiervan zijn deeltijd-opvang (dagopvang idagbehandeling en nachtopvang), tijdelijke opnames (voor weekenden en vakanties) en 'oppas' aan huis, waardoor sociale contacten en activiteiten mogelijk blijven. De resultaten van een tweetal gecontroleerde studies hiernaar bij informele zorgverleners van dementerende ouderen zijn echter niet onverdeeld positief. Hoewel de informele zorgverleners de interventies vaak op prijs stelden en positief beoordeelden, bleek na 1 jaar de belasting niet afgenomen te zijn. Ook uitstel van opname werd slechts in beperkte mate bereikt (Vernooij-Dassen en Persoon 1990, Lawton et al. 1989). Replicatieonderzoek met een langere interventie- en follow-up periode is daarom gewenst. De vraag of vergelijkbare interventies bij informele zorgverleners van ouderen met somatische aandoeningen effect sorteren dient evemeens onderzocht te worden. De resultaten van ons onderzoek geven aan dat bij de beoordeling van de aanvraag tot opname in een verpleeg- of verzorgingshuis, naast de hulpbehoefte en de aanwezigheid van zorg, aandacht besteed moet worden aan eventuele psycho-sociale problematiek als achterliggende reden voor de aanvraag en de belasting van de informele zorgverleners. De bevoegdheden van de huidige indicatie-commissies zijn echter beperkt tot de indicatiestelling woor verpleeg-en verzorgingshuizen; verwijzingen naar andere voorzieningen hebben alleen een advies status. De slagvaardigheid van deze commissies zou beduidend vergroot worden wanneer de bevoegdheden uitgebreid worden met de indicatiestelling voor alle vormen van zorg voor ouderen, dus ook de extra- en semimurale zorg. In een aantal regio's is dit overigens al het geval, maar de wettelijke status ontbreekt. Naast het voordeel dat ouderen en hun informele zorgverleners bij een zorgvraag dan maar met éen instantie te maken hebben, heeft het ook andere voordelen. Het betekent dat men in een eerder stadium in contact komt met (een deel van) de ouderen die in de toekomst een aanvraag doen voor opname in een verpleeghuis of verzorgingshuis. Door vanaf het begin de situatie goed in kaart te brengen en te volgen kan gericht verwezen worden naar de benodigde voorzie. ning(en). De vraag of opname hierdoor uitgesteld of voorkomen kan worden kan alleen door gecontroleerd onderzoek beantwoord worden. Echter, ook zonder eventuele substitutie-effecten wegen de voordelen ons inziens ruim op tegen de nadelen. Samenvattend; de substitutiemogelijkheden van zorg voor ouderen met een verpleeg* huisindicatie zijn bij de huidige voorzieningen veel geringer dan bij de ouderen met een aanvraag voor een verzorgingshuis. Van de experimenten met aanvullende zorg in bestaande voorzieningen of met nieuwe voorzieningen kan op korte en middellange termijn hooguit verwacht worden dat substitutie voor een beperkt deel van de ouderen met een verpleeghuisindicatie mogelijk zal zijn. Wel kan door uitbreiding van de bevoegdheden van de indicatie-commissies bevorderd worden dat de zorg, die vanaf het begin van hulpbehoevendheid nodig is, ook daadwerkelijk verleend wordt. 


\section{Aanbevelingen}

Op grond van de resultaten van dit onderzoek kunnen de volgende aanbevelingen gedaan worden voor de zorgverlening aan ouderen en het onderzoek op dit terrein.

Ten aanzien van de zorgverlening kan gesteld worden:

- De bewoegdheden van de indicatiecommissies dienen uitgebreid te worden met de indicatiestelling voor extra- en semimurale zorgvoorzieningen. Bij de beoordeling van aanvragen, voor welke zorgvoorziening dan ook, dient aandacht besteed te worden aan de rol en belasting van informele zorgverleners.

- De redenen voor het aanvragen van opname, vooral in een verzorgingshuis, dienen goed in kaart gebracht te worden. Wanneer psycho-sociale problemen de achterliggende reden van de aanvraag lijken te zijn, dient de inhoud van de zorg hierop afgestemd te worden. Wanneer voorzieningen als dagopvang en huiskamerprojecten effectief zijn in het verminderen van deze problematiek, kunnen deze ouderen mogelijk langer zelfstandig blijven.

- Verpleeg" en verzorgingshuizen dienen structureel een deel van hun capaciteit te gebruiken voor tijdelijke opvang ter ondersteuning van de informele zcrgverleners. Indien informele zorgverleners in een eerder stadium de mogelijkheid krijgen om niet alleen in noodsituaties maar ook in vakanties en weekenden - regelmatig de zorg de zorg te laten, wordt de belasting die het zorgen voor deze ouderen met zich mee brengt mogelijk niet zo groot. Verder onderzoek moet uitwijzen of zij hierdoor in staat zijn de zorg langer vol te houden.

- In verpleeghuizen dient bij reactiveringspatiënten nagegaan te worden of naast de paramedische zorg ook psychologische begeleiding nodig is. Het in vrij korte tijd moeten verwerken van de eigen invaliditeit en de opname, alsmede eventuele teleurstellende resultaten van de reactivering waardoor ontslag niet mogelijk is, kan een dusdanige weerslag hebben op de geestelijke toestand dat psychologische begeleiding nodig is.

Ten aanzien van onderzoek kan gesteld worden:

- Wanneer bij onderzoek een daadwerkelijke bijdrage van zorgvoorzieningen nodig is, verdient het aanbeveling dat onderzoek als gezamenlijk project van universiteit en instelling uit te voeren. Het onderzoek wordt dan ook door de instelling gedragen, hetgeen de uitvoering ten goede komt.

- Het dient onderzocht te worden wat de effecten zijn van voorzieningen als dagopvang, huiskamerprojecten, het regelmatig bezoeken van ouderen door vrijwilligers e.d., op het verminderen van psycho-sociale problematiek bij ouderen en hun gebruik van voorzieningen.

- Onderzoek naar voorzieningen, die tot doel hebben de informele zorgverleners te andersteunen, verdient eveneens aanbeveling. Daarbij zou niet alleen de aandacht gericht moeten worden op informele zorgverleners van dementerende ouderen, maar ook op informele zorgverleners van ouderen met somatische aandoeningen. Belangrijke vragen daarbij zijn of de belasting van de informele zorgverleners inderdaad minder wordt, en of zij daardoor in staat zijn langer voor de oudere te zorgen. Naast allerlei flexibele vormen van regelmatige ondersteuning, zou nagegaan kunnen worden wat het effect van case-management is, al dan niet gekoppeld aan indicatie-commissies met uitgebreide bevoegdheden. 


\section{Literatuur}

Andersen R, Kravits $J$, Anderson OW (eds). Equity in health services: empirical analysis in social policy. Cambridge, Mass, Ballinger Publishing Company 1975.

Commissie Structuur en Financiering Gezondheidszorg. Bereidheid tot verandering. Den Haag, DOP 1987.

Frederiks, CMA. Zorgbehoefte van en zorgverlening aan ouderen. Proefschrift Rijksuniversiteit Limburg, Maastricht 1990.

Van der Kam P. Mol F, Wimmers MFHG. Beoordelingsschaal voor Oudere Patiënten. Deventer, Van Loghum Slaterus 1971.

Lawton MP, Brody EM and Saperstein AR. A controlled study of respite service for caregivers of Alzheimer's patients. The Gerontologist 1989; 29: 8-16.

Loveren-Huyben CMS van, Toonen RM, Bom JA van der. Het verzorgingstehuis: een bron van toenemende zorg (2). Gedragsbeoordeling over twee en een half jaar. Tijdschrift voor Gerontologie en Geriatrie 1985; 16: 135-140.

Ministerie van WV. Ouderenbeleid. Voortgangsrapportage 1982-1988. Den Haag, Staatsuitgeverij 1988 .

Ministerie van WVC. Financieel Overzicht Zorg 1990. Den Haag. Staatsuitgeverii 1989

Mootz M, Timmermans J, Schoenmakers-Salkinoja J, Hessing-Wagner J. Samenhang in Zorg. Substitutiemogelijkheden op een viertal terreinen. Aijswijk, SCP 1986.

Nies HLGR. Dagopvang en dagverzorging voor ouderen: nieuwe voorzieningen in cntwikkeling. Tijdschrift voor Gerontologie en Geriatrie 1989; 20: 67-72.

Nuijens MJM. Sociale dagopvang voor ouderen. Een nieuwe schakel in het stelsel van woorzieningen in Arnhem? Tijdschrift voor Gerontologie en Geriatrie 1988; 19: 193-199.

Remmen, J.W.M. Bejaardenoordbewoners of verpleeghuispatiënten? Een onderzoek naar de verschillen en overeenkomsten in gezondheidstoestand tussen bejaardenoordbewoners en bejaarde chronische patiënten in verpleeghuizen voor somatisch zieken. Hoogezand: Uitgeverij Stubeg 1985.

Rossum HJL van, Frederiks CMA. Heeft preventief ouderenbezoek door wijkverpleegkundigen zin? Tijdschrift voor Gerontologie en Geriatrie 1988; 19: 3-6.

Tabachnick BG, Fidell LS. Using multivariate statistics. New York, Harper \& Row Publishers 1989.

Vereniging van Nederlandse Bejaardenoorden. Beleidsplan Sector Verzorgingstehuizen. Houten, VNB 1990. 
Vernooj-Dassen MJFJ, Persoon JMG (red). Het thuismilieu van dementerende ouderen. Een interventie-onderzoek naar effecten van professionele ondersteuning van gezins- en familieleden van dementerende ouderen. Nijmegen, Katholieke Universiteit Nijmegen, Instituut voor Sociale Geneeskunden en Nijmeegs Universitair Huisartsen Instrtuut, 1990 . 


\section{SUMMARY}

In Maastricht, a town in the south of the Netherlands, a study was conducted among elderly people ( 55 years and over) to investigate factors (other than physical limitations) leading to nursing home admission and determining the course of the nursing home stay.

For the first question, characteristics of elderly nursing home applicants and applicants to homes for the aged were compared. The data were collected by means of personal interviews with the applicants themselves and/or with their informal caregivers (when available). In the interviews, questions were asked about characteristics expected to contribute to the utilization of nursing homes. Apart from the actual need factor (in this study defined as the number of physical limitations) different predisposing and enabling factors were explored. Predisposing factors are those characteris tics that existed before the actual meed to apply for admission arose. In this study, demographic (age, gender and marital status) and social network characteristics (including the strain experienced by informal caregivers), mental status and housing condition were considered as predisposing factors. Enabling factors are those characteristics that facilitate the actual use of services, such as the accessibility of services and the socio-economic status of elderly people. Since accessibility of services will not differ much within one town, only socio-economic status and use of professional home care (public health nursing and/or home care) were inventoried in this respect.

To address the second question - which factors determine the course of the nursing home stay - the elderly people who entered a nursing home were followed for up to one year after admission. The assumption was that, within one year, the patients who would be rehabilitated would have been discharged and that those not discharged or deceased after one year would become long-stayers. Complementary data were collected in two ways. Shortly after admission and either at discharge, at death or after 1 year, the nursing home physicians in charge completed a written questionnaire on diagnoses, functional status, (achievement of) treatment goals, and prognosis. In addition, two weeks after admission and subsequently every three months, the nursing staff completed a Behavior Rating Scale for Elderly Patients.

The study is reported in 6 chapters, written as articles for journals, each elaborating on one aspect of the study. These 6 chapters are preceeded by a general introduction on nursing homes in the Netherlands. Below, the titles and abstracts of the 6 articles are presented.

\section{Nursing home admittance; a study among elderly applicants}

This chapter describes the care needs, the social network, the housing conditions, the utilization of care and the diagnoses of 157 elderly applicants to nursing homes in Maastricht. The study was carried out during the period of February 1987 to July 1988. It was investigated whether these characteristics differed in relation to the goal of the admission (rehabilitation versus continuous support) and in relation to prior living arrangements (home versus hospital). In addition "the question to what extent substitution of care is possible is discussed. Within the group of nursing home applicants, a fairly clear distinction could be made between a number of subgroups, although care needs, social network (with the exception of the number of visits paid), and demographic characteristics showed no differences in relation to admission goals and prior living arrangements. The distinction was based particularly on the nature of the disorders (psychogeriatric versus somatic and chronic versus more or less acute), which was reflected not only in the main diagnosis itself, but also in differences in 
housing conditions, numbers of yisits paid to others, and utilization of care prior to admission. Under the proposed policies for substitution, about a quarter of the applicants would be eligible for substitution. However, the major care needs, and the levels of formal and irtormal care prior to admission, as well as the shortage of alternative services, would seem to indicate that the actual possibilities for substitution are more limited.

\section{Care needs and desire to be admitted among applicants to homes for the aged; a comparison with residents of such homes}

For 135 applicants to homes for the aged, the care needs, utilization of care and desire to be admitted in the short or long term are presented and their interrelations considered. The care needs of the applicants to homes for the aged are compared with those of 207 residents of such homes. Increasing numbers of housekeeping disabilities were correlated with increasing depressive complaints "memory disturbances and, obiously, the use of formal and informal care. The care needs of the applicants were at least as great as those of the residents. They had (nearly) as many housekeeping and ADL disabilities and even more feelings of loneliness and depressive complaints. Nevertheless, the necessity of admission to a home for the aged can be questioned for those applicants with few housekeeping disabilities; the desire to be admitted at short notice was strongly associated with depressive complaints and feelings of loneliness. Provided these mental problems can be handled effectively, (more) home care could be a realistic alternative for such people.

\section{Institutionalization; a comparison of applicants to nursing homes and homes for the aged}

In order to investigate which factors, besides physical limitations, contribute to the utilization of nursing homes, a study was conducted in Maastricht among 248 elderly people. Characteristics of 113 nursing home applicants, 47 of whom were living at home and 66 of whom were in hospital, were compared with those of 135 applicants to homes for the aged. Stepwise discriminant analyses allowed a clear distinction between the groups of applicants: $91 \%$ of the applicants were correctly classified. Next to functional status, the informal care index, household composition, number of visits received and use of professional home care were important discriminating characteristics. Apart from their greater need, the nursing home applicants, especially those living at home, had a well-functioning social network and commonly received help from professional caregivers, whereas the applicants to homes for the aged were much worse off in these respects. The assumption that elderly people move along a care-continumm, in which the present use of professional care is determined by characteristics like the social network and previous use of care, given their need, thus seems to hold for applicants to homes for the aged but not for nursing home applicants. For the latter, this mechanism is apparently overruled by the functional status resulting from their medical condition. The findings imply that alternatives to institutional care will be more successful for applicants to homes for the aged than for nursing home applicants.

\section{Strain among informal caregivers of applicants to nursing homes and homes for the aged}

Informal caregivers of applicants to nursing homes $(n=69)$ and homes for the aged $(n=46)$ were interviewed to study the strain they experienced. It was investigated whether informal caregivers of nursing home applicants experience more strain than those of the applicants to homes for the aged. Furthermore, the assaciations of 
various factors with the strain were analyzed to gain insight into the strain experienced. The results of the bivariate analysis showed that the care given by the informal caregiver, aspects of the health of the informal caregiver "the care needs of the applicant and living with the applicant were related to the strain experienced, together with the type of caregiving (whether care is given to an applicant to a nursing home or to a home for the aged). Most of these factors were interrelated as well. When considered simultaneously, only feelings of loneliness, self-rated health and the type of caregiving appeared to have an independent association witl the strain experienced. Apparently, the variables were interrelated in such a way that some variables did not provide additional information on the strain experienced if the influence of other variables was controlled for. The results further revealed that informal caregivers of nursing home applicants did experience more strain than those of applicants to homes for the aged. The type of caregiving on its own explained $4 \%$ of the variance in the strain experienced. In all $42 \%$ of the variance in the strain experienced was explained.

\section{The course of nursing home stays}

This chapter describes the course of the nursing home stays of 157 newly admitted patients using the Behavior Rating Scale for Elderly Patients ('Beoordelingsschaal Oudere Patienten'). The follow-up period lasted a maximum of 1 year. It was investigated whether the course differed in relation to the objective of the admission (rehabilitation versus continuous support) and whether factors could be indicated which impeded or advanced the discharge of the rehabilitation patients. For that purpose, information on diagnoses, prognosis, goals of the treatment and their achievement. and disability according to SIVIS (SIG Nursing Home Information System) was also obtained from the physicians in charge at the nursing home.

The course of the nursing home stay differed for chronic and rehabilitation patients. In addition to physical disability and depressive behavior, the chronic patients, from the time of admission onwards, had more behavioral problems than the rehabilitation patients. Moreover, their dependency, physical and mental disability and inactivity increased during the stay. For two thirds of the rehabilitation patients, the stay did not end in discharge from the nursing home. For this group, the dependency, aggressiveness, and depressive behavior increased during the stay. The outcome of rehabilitation appeared to be related to the extent of behavioral problems, to the level of disability, and to the medical condition at admission. The least disabled and the "medically least complex" patients could usually be discharged with an improved level of functioning, which seemed to justify the nursing home stay. The lack of availability of other services impeded discharge in a few cases. For the chromic patients, as well as for the rehabilitation patients still resident after 1 year, residency in a home for the aged as an alternative to nursing home care appears difficult to realize, in view of the extent of behavioral problems.

\section{Determinants of the outcome of nursing home stays}

A one year prospective study among 157 nursing home patients was performed to investigate which admission characteristics are related to the outcome of the nursing home stay. After one year, $41 \%$ of the patients had died, $44 \%$ were still residents and only $15 \%$ were discharged home or to a home for the aged. The results of a polychotomous logistic regression analysis show that the functional status was associated with all outcomes, as could be expected. The number of diagnoses differentiated between being discharged and being deceased. Age and gender differentiated between still being a resident and being deceased: males and patients over 80 were 
more likely to die. The nature of the main diagnoses differentiated between being still resident and being deceased and between being discharged and being still resident: somatic patients were more likely either to die or to be discharged than psychogeriatric patients. The strain experienced by informal caregivers prior to the admission differentiated between being discharged and still being a resident, indicating that pathents whose caregivers experienced more strain prior to the admission were less likely to be discharged. For $54 \%$ of the patients, the observed outcome corresponded with the outcome predicted by the logistic regression model. Most mistakes were made by the model in distinghuishing still resident patients from deceased patients and vice versa. A more precise measurement of the health and functional status of the patients might improve the prediction, as well as the inclusion of more of these variables. The same is true for the non-health variables. But, as non-health variables seem easier to manipulate than health variables, a further exploration of the social network and prior living arrangements is indicated, if ways are to be found to reduce the utilization of nursing homes.

The thesis concludes with an epilogue in which the methods and the results of the study as a whole are considered. In addition, a number of policy implications are discussed.

With regard to the first question, it is concluded that the need factors - care needs and nature of the disorders - are decisive for the nursing home admission. Predisposing and enabling factors, i.e. social network and use of professional home care, played little or no role at higher care need levels. Among patients with chronic disorders these factors are no longer sufficient. In the case of more or less acute disorders, these factors are not sufficient to prevent nursing home admission.

With regard to the second question it is found that functional status, number of diagnoses, nature of the main diagnosis (somatic or psychogeriatric), age, gender, and strain experienced by the informal caregivers prior to admission, were determinants of outcome of the nursing home stay (whether or not the patient was discharged, deceased or still resident).

The results of the whole study indicate that the possibility of substituting care for elderly people, given the present system of services, is much more limited for nursing home applicants than for applicants to homes for the aged.

In the end recommendations for the care for elderly people and research are formulated, which are summarized below.

Recommendations with regard to the care for elderly people:

- The competences of the special committees, which decide whether applications to nursing homes and homes for the aged are justified, should be extended to include judgement of applications to extramural and semimural care (e.g. professional home care and day care). In judging the applications, the rolle and strain of the informal caregivers should be taken into account.

- The reasons for applying to institutional care have to be inventoried carefully. If psycho-social problems are the reasons behind the application, the content of care should be adapted according to these problems.

- Nursing homes and homes for the aged should use part of their structural capacity for respite care to support the informal caregivers.

- For rehabilitation patients, the need for psychological care in addition to paramedical care should be considered.

Fiecommendations for research:

- Field research conducted in service providing organizations should be conducted as a shared project of the university and the organization. 
- The effects of services such as day care, "living room projects", regular visits to the elderly people by, for instance, volunteers, on decreasing psycho-social problems and the utilization of services need to be investigated.

- The effects of respite care for informal caregivers on the strain experienced and on the utilization of services should be studied. Such research should not only concern informal caregivers of patients with dementia, but should include informal caregivers of patients with somatic disorders as well. 



\section{SAMENVATTING*}

In Maastricht is een onderzoek verricht onder ouderen $(55+)$ naar factoren die, naast de mate van invaliditeit, leiden tot opname in een verpleeghuis en naar factoren die het verloop van de verpleeghuisopname bepalen.

Voor de eerste vraagstelling zijn kenmerken van ouderen met een verpleeghuisindicatie vergeleken met die van ouderen met een positieve indicatie voor opname in een verzorgingshuis. De gegevens zijn verzameld door middel van mondelinge interviews met deze ouderen zelf en/of hun informele zorgverleners (indien aanwezig). In deze interviews is gevraagd naar kenmerken waarvan verwacht kon worden dat zij bij zouden dragen aan het gebruik van verpleeghuizen. Naast de eigenlijke behoeftefactor, in dit onderzoek gedefinieerd als het aantal lichamelijke beperkingen, zijn verschillende faciliterende en predisponerende factoren onderzocht. Tot de predisponerende factoren worden kenmerken gerekend die al aanwezig waren voordat de eigenlijke aanleiding tot de aanvraag voor opname ontstond. In dit onderzoek zijn naast demagrafische kenmerken (leeftijd, geslacht en burgerlijke staat), het sociale netwerk inclusief de belasting van de informele zorgverleners, de geestelijke toestand en de woonsituatie als predisponerende factoren opgenomen. Faciliterende factoren zijn kenmerken die iemand in staat stellen om van de gewenste zorg gebruik te kunnen maken, zoals de toegankelikkheid van voorzieningen en de sociaal-economische status. Omdat de toegankelijkheid van voorzieningen binnen éen stad niet veel zal verschillen, zijn alleen de sociaal-economische status en het gebruik van professionele thuiszorg (wijkverpleging en/of gezinszorg) als faciliterende factoren opgenomen.

Voor de tweede vraagstelling - welke factoren bepalen het verloop van de verpleeghuisopname - zijn de ouderen die werden opgenomen in een verpleeghuis maximaal 1 jaar gevolgd. De veronderstelling daarbij was dat binnen 1 jaar de reactiveerbare patiënten uit het verpleeghuis zouden zijn ontslagen en dat zij die na 1 jaar nog opgenomen waren "long-stay" patiënten zouden worden. Aanvullende gegevens werden op twee manieren verzameld. De behandelend verpleeghuisarts vulde kort na de opname en bij ontslag of overlijden c.q. na 1 jaar opname, een schriftelijke vragenlijst in over de diagnosen, de functionele status, (het bereiken van) de behandeldoelen en de prognose. Daarnaast werd 2 weken na opname, en vervolgens om de 3 maanden, door het verplegend personeel een Beoordelingsschaal voor Oudere Patiënten (BOP) ingevuld.

Het onderzoek is weergegeven in 6 hoofdstukken die elk, in de vorm van een tijdschriftartikel, een bepaald aspect van het onderzoek belichter. Deze 6 hoofdstukken worden voorafgegaan door een algemene inleiding over verpleeghuizen in Nederland. Hieronder volgen de titels en een korte samenvatting van de 6 artikelen.

\section{Verpleeghuilsopname; een onderzoek bi] op te nemen ouderen}

In dit hoofdstuk worden de hulpbehoefte, het sociale netwerk, de woonsituatie, het gebruik van zorg en de hoofddiagnose beschreven van 157 ouderen die werden op. genomen in een verpleeghuis. Nagegaan is of deze kenmerken verschillen naar aard van verblijf vóór de opname (eigen omgeving versus ziekenhuis) en het doel van de verpleeghuisopname (reactivering versus permanente ondersteuning). Tevens wordt

* De hoofdstukken Inleiding en Besluit van dit proefschrift zijn ook zonder de lussenliggende hoofdstukken te lezen. Naast een weergave wan de opzet en de resultaten wordt het onderzoek in deze hoofdstukken in een breder kader geplaatst. 
ingegaan op de vraag in hoeverre bij deze ouderen substitutie mogelijk is. Binnen de groep op te nemen verpleeghuispatienten zijr vrij duidelijk subgroepen te onderscheiden, alhoewel de hulpbehoefte, het sociale netwerk, met uitzondering van het op bezoek gaan, en de achtergrondkenmerken niet bleken te verschillen naar aard van verbliji vó́r opname en doel van de opname. Het onderscheid ligt vooral in de aard van de aandoeningen (psychogeriatrisch versus somatisch en chronisch versus min of meer acuut), hetgeen niet alleen uit de hoofddiagnose zelf, maar ook uit verschillen in woonsituatie, het op bezoek gaan bij anderen en het gebruik van zorg voorafgaand aan de opname naar voren kornt. Gegeven het voorgestelde substitutiebeleid zou ruilm een kwart van deze op te nemen patiënten in aanmerking komen voor substitutie. De zware hulpbehoefte en de omvang van de informele en professionele zorg voorafgaand aan de opname, naast een tekort aan alternatieve woonvormen, doen echter vermoeden dat de substitutiemogelijkheden in werkelijkheid veel beperkter zijn.

\section{De hulpbehoefte en opnamewens van positief geïndiceerde ouderen voor het verzorgingshuis; een vergelijking met verzorgingshuisbewoners}

De hulpbehoefte, het zorggebruik en de opnamewens van 135 ouderen met een positieve indicatie voor opname in een verzorgingshuis worden gepresenteerd. Nagegaan is hoe deze factoren onderling samenhingen en in hoeverre de hulpbehoefte van de positief geindiceercien verschilde van die van 207 verzorgingshuisbewoners. Naarmate de positief geïndiceerden meer huishoudelijke beperkingen hadden namen depressieve klachten, geheugenstoornissen en, zoals verwacht, het gebruik van professionele en informele zorg toe. De hulpbehoefte van de positief geindiceerden was minstens zo groot als die van verzorgingshuisbewoners. Zij hadden (bijna) evenveel huishoudelijke en ADL-beperkingen en zelfs meer eenzaamheidsgevoelens en depressieve klachten. Toch kan voor de positief geïndiceerden met weinig huishoudelijke beperkingen de noodzaak van opname betwijfeld worden. De wens om op korte termijn opgenomen te worden was namelijk sterk geassocieerd met depressieve klachten en eenzaamheidsgevoelens. Mits extramuraal een effectieve aanpak gevonden wordt voor deze geestelijke problematiek kan (meer) thuiszorg voor hen een alternatief zijn.

\section{Institutionalisering: een vergelijking van verpleeghuisaanvragers met verzorgingshuisaanvragers}

Om na te gaan welke factoren, naast de mate van invaliditeit, bijdragen aan het gebruik van verpleeghuizen is een onderzoek uitgevoerd bij 248 ouderen in Maastricht. Met behulp van stapsgewijze discriminant-analyses zijn kenmerken van 113 verpleeghuisaanvragers (47 thuiswonenden en 66 aanvragers die in een ziekenhuis verbleven) vergeleken met 135 verzorgingshuisaanvragers. De groepen aanvragers konden op basis van de discriminant-analyses goed onderscheiden worden: $91 \%$ van de aanvragers werd in de goede groep ingedeeld. De hulpbehoefte, de informele zorg-score, de samenstelling van het huishouden, het ontvangen bezoek en het gebruik van professionele thuiszorg waren belangrijke discriminerende variabelen. Naast hun grotere hulpbehoefte bleken de verpleeghuisaanvragers, vooral de thuiswonenden, een beter functionerend sociaal netwerk te hebben en veel vaker professionele zorg te gebruiken dan de verzorgingshuisaanvragers. De veronderstelling dat het zorggebruik van ouderen, op het continuüm van zelfzorg en informele zorg aan de ene kant en gespecialliseerde institutionele zorg aan de andere kant, gegeven de hulpbehoefte, bepaald wordt door kenmerken als het sociale netwerk en het eerdere gebruik van zorg lijkt dus wel op te gaan voor verzorgingshuisaanvragers, maar niet voor verpleeghuisaanvragers. Blijkbaar wordt dit mechanisme bij verpleeghuisaanvra- 
gers 'overruled' door hun hulpbehoefte. De bevindingen impliceren dat alternatieven voor institutionele zorg meer succesvol zullen zijn bil verzorgingshuisaanvragers dan bij verpleeghuisaanvragers.

\section{De ervaren belasting bij informale zorgverleners van verpleeg- en verzorgingshuisaanvragers}

Informele zorgverleners van verpleeghuisaanvragers $(n=69)$ en verzorgingshuisaanvragers ( $n=46$ ) zijn geïnteviewd om de belasting die zij ervaren bij het zorgen voor de aanvragers te onderzoeken. Nagegaan werd of de informele zorgverleners van verpleeghuisaanvragers meer belasting ervaren dan die van verzorgingshuisaanviagers. Om inzicht te krijgen in de ervaren belasting werd nagegaan of, en zo ja, welke factoren samenhangen met de ervaren belasting. Bivariaat bleken de zorg die verleend werd door de informele zorgverlener, gezondheidsaspecten van de informele zorgverlener, de maten voor de hulpbehoefte van de aanvrager en het all dan niet samenwonen met de aanvrager gerelateerd te zijn met de ervaren belasting, evenals de soort zorgverlening (of de zorg aan een verpleeghuisaanvrager of aan een verpleeghuisaanvrager gegeven werd). Veel van deze factoren bleken ook onderling samen te hangen. Wanneer deze factoren gelijktijdig in verband gebracht werden met de ervaren belasting, dan bleken alleen de eenzaamheidsgevoelens, de subjectieve gezondheidsbeleving en de soort zorgverlening een onafhankelijke associatie te hebben met de ervaren belasting. Blijkbaar zijn de factoren onderling dermate gecorreleerd dat de overige geen informatie meer bijdragen wanneer gecontroleerd wordt voor de invloed van andere factoren. De resultaten lieten tevens zien dat informele zorgverleners van verpleeghuisaanvragers inderdaad meer belasting ervaren dan die van de verzorgingshuisaanvragers. De soort zorgverlening alléén verklaarde $4 \%$ van de variantie in ervaren belasting. In totaal werd $42 \%$ van de variantie in de ervaren belasting verklaard.

\section{Het verloop van verpleeghuisopnamen}

Dit hoofdstuk beschrijt het verloop van de verpleeghuisopname van 157 nieuw opgenomen patiënten met behulp van de Beoordelingsschaal Oudere Patiënten. Zij zijn voor een periode van maximaal 1 jaar gevolgd. Nagegaan is of het verloop verschilt naar het doel van de opname (reactivering versus permanente ondersteuning) en of er voor de groep reactiveringspatiënten ontslag belemmerende danwel bevorderende factoren aan te wijzen zijn. Daarbil werd tevens gebruik gemaakt van informatie van de behandelend verpleeghuisarts over de diagnosen, prognose, (het bereiken van) de behandeldoelen en de SIVIS-validiteit.

De verpleeghuisopname bleek voor chronische en reactiveringspatiënten verschillend te verlopen. Met uitzondering van de lichamelijke invaliditeit en depressief gedrag hadden de chronische patiënten vanaf de opname meer gedragsproblemen dan de reactiveringspatiënten. Hun hulpbehoevendheid, lichamelijke en psychische invaliditeit alsmede de inactiviteit namen bovendien toe tijdens de opname. Bij tweederde van de reactiveringspatiënten leidde de opname niet tot functieverbetering en ontslag uit het verpleeghuis. Bij deze groep namen de hulpbehoevendheid agressiviteit en het depressief gedrag toe tijdens de opname.

Het succes van de reactivering bleek samen te hangen met de mate van gedragsproblemen, validiteit en de medische toestand bij opname. De minst hulpbehoevende en de 'medisch minst complexe" patiënten konden veelal met functieverbetering ontslagen worden, hetgeen de verpleeghuisopname legitimeert. Het niet beschikbaar zijn van andere zorgwoorzieningen was in een klein aantal gevallen een ontslagbelemmerende factor. Verblijf in een verzorgingshuis als alternatief voor verpleeghuiszorg 
voor de chronische patienten, maar ook woor de reactiveringspatienten die na een jaar nog opgenomen zijn, lijkt, gezien de mate van gedragsproblemen, niet eenvoudig te realiseren.

\section{Determinanten van de 'uitkomst' van verpleeghuisopnamen}

Om na te gaan welke opname-kenmerken gerelateerd zijn aan de 'uitkomst' van verpleeghuisopnamen, zijn 157 verpleeghuispatiënten tot 1 jaar na de opname gevolgd. Na 1 jaar was $41 \%$ van de patiënten overleden, $44 \%$ was nog steeds opgenomen en slechts $15 \%$ was ontslagen naar huis of naar een verzorgingshuis. Uit een trichotome logistische regressie-analyse komt naar voren dat de functionele status bij opname, zoals verwacht, geassocieerd was met alle uitkomsten. Het aantal diagnosen differentieerde tussen overleden en ontslagen zijn. Leeftijd en geslacht differentieerde tussen nog opgenomen en overleden zijin: mannen en patiënten ouder dan 80 jaar hädden meer kans om te overlijden. De aard van de hoofddiagnose differentieerde tussen nog opgenomen en overleden zijn en tussen ontslagen en nog opgenomen zijn: somatische patiênten hadden meer kans om of te overlijden of ontslagen te worden dan psychogeriatrische patiënten. De belasting die de informele zorgverleners voorafgaand aan de opname ervaarden, differentieerde tussen ontslagen en nog opgenomen patiënten: indien de informele zorgverleners zwaarder belast waren, was de kans om ontslagen te worden kleiner. Het logistische regressie model voorspelde de 'uitkomst' van de opname bij $54 \%$ van de patiënten correct. Het model ondervond vooral moeilijkheden bij het woorspellen welke patiënten na 1 jaar overleden dan wel nog opgenamen zouden zijn. De predictie kan mogelijk verbeterd worden door meer en/of gevoeliger maten voor de functionele status en de gezondheidstoestand te gebruiken. Hetzelfde geldt voor kenmerken als het sociale netwerk en de eerdere woonomstandigheden. Een verdere exploratie van met name deze kenmerken is aangewezen, wanneer het doel is manieren te vinden om het gebruik van verpleeghuizen te verminderen.

Het proefschrift eindigt met een besluit waarin de opzet en de resultaten van het onderzoek in hun geheel nog eens beschouwd en becommentarieerd worden. Ook worden daarin een aantal beleidsimplicaties besproken en aanbevelingen gedaan voor de zorg aan ouderen en verder onderzoek. Ten aanzien van de eersite vraagstelling wordt geconcludeerd dat de behoeftefactoren - de hulpbehoefte en de aard van de aandoeningen - doorslaggevend zijn bij opname in een verpleeghuis. Predisponerende en faciliterendle factoren, i.c. het sociale netwerk en hel gebruik van professionele thuiszorg, spelen bij een bepaalde mate van hulpbehoefte geen rol meer. Gegeven die mulpbehoefte zijin deze factoren bil chronische aandoeningen uiteindelijk niet meer voldoende en bij meer acute aandoeningen niet voldoende om verpleeghuisopname te voorkomen. Ten aanzien van de tweede vraagstelling komt naar voren dat de functionele status, het aantal diagnosen, de aard van de hoofddiagnose (somatisch of psychogeriatrisch), leeftijd, geslacht en de belasting die de informele zorgverleners ervaarden voorafgaand aan de opname van invloed zijn op de 'uitkomst' van de opname (het al dan niet ontslagen, overleden of nog opgenomen zijn).

De resultaten van het gehele onderzoek geven aan dat de mogelijkheden van substitutie van zorg voor ouderen met een verpleeghuisindicatie bij het huidige stelsel van voorzieningen veel geringer zijn dan voor ouderen met een positieve indicatie voor opname in een verzorgingshuis. 


\section{DANKWOORD}

Promoveren lijkt een eenzame bezigheid, maar dat is het niet. Terugkijkend op de jaren dat ik met mijn onderzoek bezig ben geweest, heb ik van veel mensen bil de meest uiteenlopende zaken hulp en ondersteuning gekregen. Een aantal van hen wil ik hier met name noemen.

De ouderen en hun informele zorgverleners die mij en de overige interviewers te woord hebben gestaan, staan aan de basis van dit onderzoek. Dat zij, ondanks de vaak moeilijke situatie waarin zij zich bevonden, aan de interviews meewerkten verdient niet alleen dank, maar ook respect. Hetzelfde geldt voor de interviewers: uit eigen ervaring weet ik dat het interviewen lang niet altijd gemakkelijk was. Daarom veel dank aan vooral Miep Jennekens, Jos Hamers en Sonja Faas.

De Maastrichtse verpleeghuizen Klevarie en de Zeven Bronnen verleenden hun medewerking aan het onderzoek, evenals de Gemeentelike indicatiecommissie. De vragenlijsten en de beoordelingsschalen werden trouw door de verpleeghuisartsen en het verzorgend personeel van de verpleeghuizen ingevuld. De administratieve ondersteuning, die op efficiënte en plezierige wijze werd verleend door mevr. Poolen, was daarbij onontbeerlijk.

De vele gegevens werden met huip van vooral لlos Hamers, Gerrie Eussen on Annemie Mordant ingevoerd en gecontroleerd. De analyses wilde ik zelf doen, maar wanneer de computerprogramma's mij de baas werden, waren Harm Hospers, Paul Geelen en Marian Maaskant altijd zo lief om mij weer op het goede spoor te zetten. De ins en outs van logistische regressieanalyse bleken ingewikkelder dan de computerprogrammatuur op zich. Lex Volovics was zo vriendelijk om datgene wat ik uitdraaide en daarover opschreef op statistische en klinische relevantie te beoordelen. Van mijn collega's bij de vakgroep Epidemiologie/Gezondheidszorgonderzoek heb ik. in meerdere opzichten, veel geleerd. Het was een goede thuisbasis.

Mijn promotor Ferd Sturmans en co-promotor Adriaan Visser waren vooral in de schrijfase actief. Beiden wil ik danken voor de accurate wijze waarop zill de vele concepthoofdstukken van commentaar hebben voorzien. Ferd wil ik bovendien bedanken voor de prettige wijze waarop hij behulpzaam was bij de, zowel inhoudelijke als procedurele, laatste loodjes.

Carla Frederiks, mijn eerste co-promotor, is de aanleiding van dit al. Vanaf het prille begin heeft zij mij begeleid. Zij en ik weten dat zij heel wat met mij te stellen heeft gehad. Haar vertrouwen in mij, haar inzet en haar adequate wijze van begeleiden zijn dan ook zeer belangrijke verklarende factoren bij de totstandkoming van dit proefschrift. Niet alleen je inhoudelijke capaciteiten, maar ook je humor en je frisse kijk op het leven maken dat het een voorrecht is om met je samen te werken!

Met Erik van Rossum heb ik al die jaren een kamer en (onderzoeks-) lief en leed gedeeld. Daarnaast was thij vanaf het begin behulpzaam bij alle voorkomende werkzaamheden. Alles werd op de van hem bekende wijze - niet op de voorgrond treden, maar gewoon doen - vakkundig en snel gedaan, ongeacht of het nu interviewem, invoeren van data, het becommentariëren van concepten of wat dies meer zij betrof. Nu we geen kamer meer delen, realiseer ik me hoe vaak we discussieerden over onze onderzoeken, samen uitdraaien bekeken of gewoon lol hadden. Gelukkig komen we elkaar nog regelmatig tegen!

Hoewel het er soms wel wat van weg had, vormden we samen met Carla geen zelfhulpgroep. Daarom was de morele en praktische steun van (ex-)lotgenoten Marian Maaskant en Piekie de Vet vaak meer dan welkom. Jan Klerckx maakte, soms in zeer korte tijd, van mijn Engels het Engels dat ik eigenlijk had willen schrijwen. 
Mart van Golde ontwierp enthousiast de omslag. Thum Aarts (Wolder) maakte van het binnenwerk een prachtig boekje.

Ook buiten het werk hebben velen uit vrienden-en tamiliekring een bijdrage gehad. Mijn ouders wil ik danken voor het feit dat zij mij de vrijheid hebben gelaten om die dingen te doen die ik wilde doen. Mijn broers en zussen en hun eega's hebben mijn belevenissen altijd met belangstelling gevolgd. In goede èn in slechte tijden kon ik altijd bij hen en bij mijn ouders terecht. Dat geldt ook voor mïn vrienden en vriendinmen. Marie-Anne, Harry en de kids Pieter-Jan en Sarah nemen in dit opzícht een speciale plaats in. Hun huis is mijn tweede thuis. Graag én vaak heb ik me door hen laten verwennen.

Niet lang nadat ik Gerben beter leerde kennen leek het allemaal weel beter te gaan. Gerben, de vraag of jij daarvan de etiologische factor bent of alleen een effectmodificerende rol hebt gespeeld, is ongecontroleerd eigenlijk niet te beantwoorden. Toch durf ik met zekerheid te stellen dat het géen toeval is geweest. Ik ben blij met je!

Margreet te Wierik, augustus 1991. 


\section{CURRICULLIM VITAE}

Margreet te Wierik werd op 26 februari 1962 te Raalte geboren. Zij volgde haar middelbare schoolopleiding aan het Florens Radewijns College te Raalte. Na het behalen van het Atheneum B diploma in 1980 studeerde zij Gezondheidswetenschappen (toen Sociale Gezondheidkunde geheten) aan de Rijksuniversiteit Limburg te Maastricht. In 1985 werd deze studie afgesloten met als afstudeerrichting Beleid en Beheer van gezondheidsvoorzieningen. Tijdens het laatste jaar van de studie was zij student-assistent bij het onderzoeksproject 'Zorgbehoefte van en zorgverlening aan ouderen'. Vanaf september 1985 tot november 1990 was zij als wetenschappelijk assistent werkzaam bij de vakgroep Epidemiologie/Gezondheidszorgonderzoek van de Rijksuniversiteit Limburg. Tijdens deze periode heeft zij voornamelijk gewerkt aan het onderzoek dat in dit proefschu ift beschreven wordt. Daarnaast had zij verschillende onderwijstaken binnen de Faculteit der Gezondheidswetenschappen. Vanaf april 1991 is zij als universitair docent werkzaam bij de vakgroep Verplegingswetenschap van dezelfde universiteit. 